\title{
The Early Carboniferous (Mississippian) ammonoids from the Chebket el Hamra (Jerada Basin, Morocco)
}

\author{
Dieter Korn $^{*}, 1$ and Volker Ebbighausen ${ }^{2}$ \\ 1 Dieter Korn, Museum für Naturkunde der Humboldt-Universität zu Berlin, Invalidenstraße 43, 10115 Berlin, Germany. \\ E-mail: dieter.korn@museum.hu-berlin.de \\ ${ }^{2}$ Volker Ebbighausen, Engstenberger Höhe 12, 51519 Odenthal, Germany. E-mail: volker@vxr.de
}

\begin{abstract}
Received 31 December 2007

Accepted 31 January 2008

Published 1 August 2008

\section{Key Words}

Ammonoidea

ontogeny

systematics

biogeography

biostratigraphy

Five Late Viséan ammonoid assemblages of North Variscan provenance are described from the locality Chebket el Hamra (Jerada Basin, north-eastern Morocco). These assemblages are composed of 27 species of the genera Eoglyphioceras, Girtyoceras, Sulcogirtyoceras, Metadimorphoceras, Goniatites, Arnsbergites, Hibernicoceras, Paraglyphioceras, Lusitanoceras, Sudeticeras, Neoglyphioceras, Lusitanites, Ferganoceras, Praedaraelites, and Pronorites. The new subfamily Arnsbergitinae is described, as well as the thirteen new species Eoglyphioceras minutum n. sp., Girtyoceras ibnkhaldouni n. sp., Metadimorphoceras anguinosum n. sp., Arnsbergites ferrus n. sp., Arnsbergites proiecturus n. sp., Arnsbergites rufus n. sp., Hibernicoceras touissitense n. sp., Hibernicoceras artilobatum n. sp., Paraglyphioceras celeris n. sp., Lusitanoceras zirari n. sp., Sudeticeras ibnbajjahi n. sp., Sudeticeras horoni n. sp., and Pronorites owodenkoi n. sp.
\end{abstract}

\section{Introduction}

North-western Africa is a key region for the understanding of Carboniferous ammonoid evolution and biogeography. Although the occurrences in Morocco and Algeria do not belong to the 'classical'areas of Palaeozoic ammonoid palaeontology, they can be regarded now as one of the most promising sites for future investigations.

Carboniferous ammonoids from North Africa were discovered at the beginning of the $20^{\text {th }}$ century and were described in a short article by Dollé (1912), much later than occurrences from other regions such as North England (e.g. Phillips 1836, 1841), Belgium (e.g. de Koninck 1844, 1880), the Rhenish Mountains (e.g. Sandberger \& Sandberger 1850-1856), and the American Midcontinent (e.g. Hall 1860). A more extensive description of ammonoids from north-western Algeria was provided by Menchikoff (1930), before Delépine (1941) summarised the knowledge of that time in his monograph on the Carboniferous ammonoids from North Africa. His descriptions are mainly based on material assembled in the 1930s by the field investigators Clariond, Owodenko, Menchikoff, Neltner, and particu- larly H. Termier (1936a, 1936b). The material available to Delépine was collected in various places in Morocco and north-western Algeria, and was mostly composed of rather species-poor assemblages of which the precise stratigraphy was not known.

Pareyn (1961) used sections in the area of BéniAbbès and Béchar to establish a stratigraphy that was based on lithological as well as palaeontological data. He showed that the Viséan rocks of his study area are rather rich in ammonoids, and pointed out close similarities of their faunas with the occurrences in the South Urals. It was mainly the study by Pareyn that placed North Africa among the important Carboniferous ammonoid-yielding regions.

The coal basin of Jerada in north-eastern Morocco was discovered in the late 1920s (Harroy \& Brichant 1928) and was intensely studied and subsequently mapped (Owodenko 1946, 1976; Horon 1952). Owodenko was able to find a number of fossil horizons, which permitted dating and subdivision of the succession. Based on ammonoids, an interval from the late Viséan up to the late Westphalian could be correlated with the successions in Central and North-western Eu-

\footnotetext{
* Corresponding author
} 
rope. He investigated the area of the Chebket el Hamra in the vicinity of Touissit during field excursions in 1933 and 1934 and collected ammonoid material, which he sent to Delépine for interpretation. Few specimens were described and figured by Delépine (1941), but the fossil list gives an impression of the rather diverse fauna from that locality.

We investigated the area of the Chebket el Hamra during a field trip in 2006 supplemented by another in 2007. Our focus was the separation of distinct ammonoid-bearing horizons and the collection of rich assemblages, which allow a comparison with the time equivalents from other North African occurrences (such as the Anti-Atlas and the area around Béchar) and from the Subvariscan occurrences in Europe (such as South Portugal and Ireland).

With this report, we introduce a monograph on the ammonoid faunas from the Chebket el Hamra as a tool to discuss Carboniferous biogeography of Iberia and North Africa. It is a continuation of the monographic descriptions of the Carboniferous ammonoid faunas from north-western Africa (Ebbighausen et al. 2004; Bockwinkel \& Ebbighausen 2006; Klug et al. 2006; Ebbighausen \& Bockwinkel 2007).

\section{Geographic and geological setting}

The Chebket el Hamra (Chebikat el Hamra on modern maps) is a low butte, capped by Liassic sediments, on the east-northeastern extension of the Jerada Basin of east-northeast Morocco, $50 \mathrm{~km}$ south of the province capital Oujda, and immediately west of the mining town of Touissit (Figs 1-2). It was studied by a number of researchers (e.g. Brichant 1932, 1935; Clariond 1933; Clariond \& Termier 1933) and intensely investigated and mapped by Owodenko (1946), who used the age determination of the fossil-bearing rocks previously given by Delépine (1941).

The Carboniferous rock succession in the Jerada Basin consists of rhyolites, cherts, shallow-water carbonates, shales, and sandstones; it is exposed there in an asymmetric syncline with a WSW-ENE axis. It possesses a steep southern flank (80-90 inclination) and gently dipping strata in the northern flank $\left(20-30^{\circ}\right)$. The N-S extension reaches $17 \mathrm{~km}$ in length, and the $\mathrm{W}-\mathrm{E}$ extension to approximately $50 \mathrm{~km}$. Portions of the Carboniferous rocks are covered by Mesozoic sediments, particularly towards the east where the Jerada Syncline dips below a Triassic and Jurassic cover. Stratigraphically the rock succession in the Jerada Basin extends from the Viséan into the Moscovian, as demonstrated by ammonoids (Delépine 1941; Owodenko 1946; Horon 1952; Owodenko \& Horon 1952; Bouckaert \& Owodenko 1965) and foraminifers (Vachard \& Berkhli 1992; Berkhli et al. 1993, 1999a).

Following the earlier study by Owodenko, the Viséan rocks were re-investigated by Horon (1952) and Berkhli et al. (1993, 1999a, 1999b). In these articles, the succes-

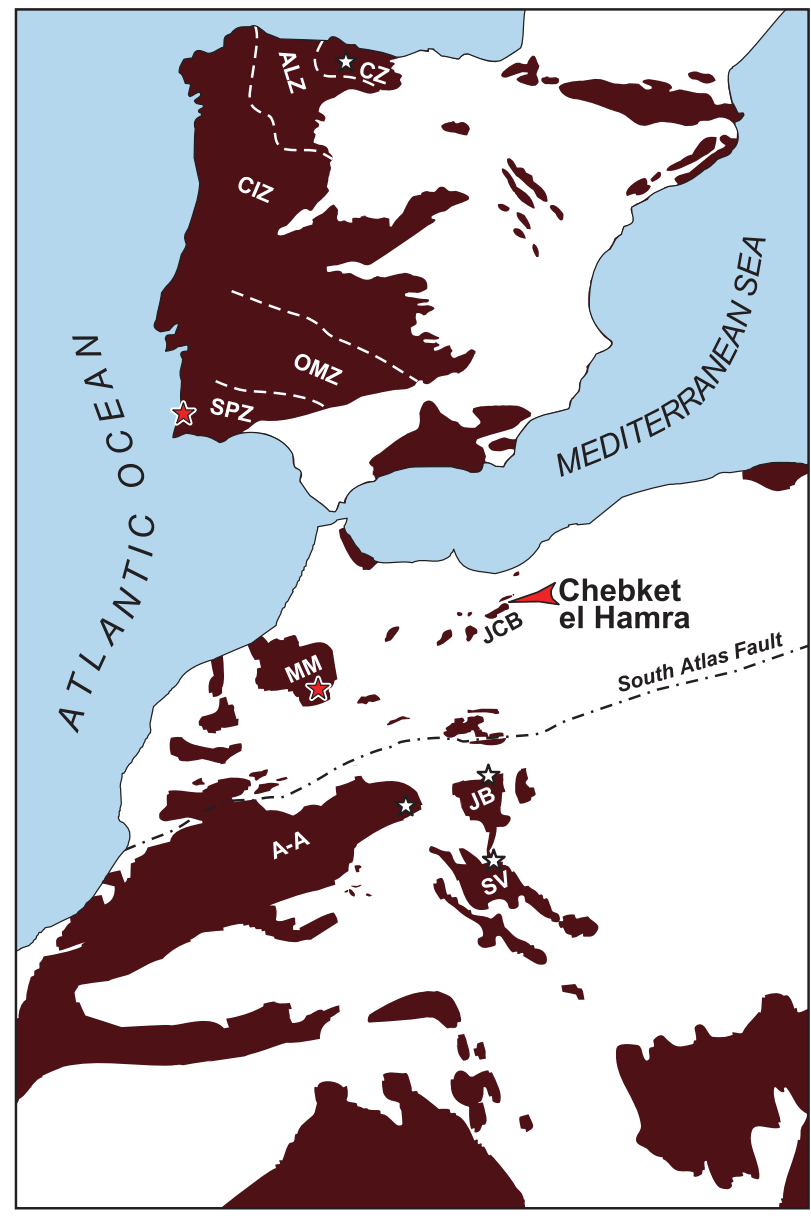

Figure 1. The outcrop of Palaeozoic rocks in North-western Africa and Iberia, the occurrences of Late Viséan ammonoid faunas (marked by asterisks), and the geographic position of the Chebket el Hamra. [CZ, Cantabrian Zone; ALZ, AsturoLeonese Zone; CIZ, Central Iberian Zone; OMZ, Ossa-Morena Zone; SPZ, South Portuguese Zone; MM, Moroccan Meseta; JCB, Jerada Basin; A-A, Anti-Atlas; JB, Jebel Béchar; SV, Saoura Valley]. This figure is available in colour online at museum-fossilrecord.wiley-vch.de

sion of the Jerada Coal Basin was described in detail in the context of biostratigraphy and sequence stratigraphy. Formation names were proposed for the distinctive rock units by Berkhli et al. The Viséan interval, on the northern flank of the syncline, was subdivided into two major cycles, of which the lower was placed in the late Asbian, and the upper in the Brigantian (both Late Viséan).

As will be shown below, both formations are obviously identical.

The Carboniferous rocks of the Chebket el Hamra form the north-easternmost extension of the Jerada Basin. The small occurrence crops out in a tectonic horst structure, in an area of approximately $3 \times 8 \mathrm{~km}$ was uplifted and subsequently opened due to the erosion of the covering Mesozoic rocks. Structurally, the occurrence at the Chebket el Hamra belongs to the northern flank of the Jerada Syncline, with the beds dipping at $20-30^{\circ}$ to the south-southeast. The section begins with approximately $20 \mathrm{~m}$ of tuffites and turquoise-coloured cherts, followed by a sequence of more than $50 \mathrm{~m}$ of 

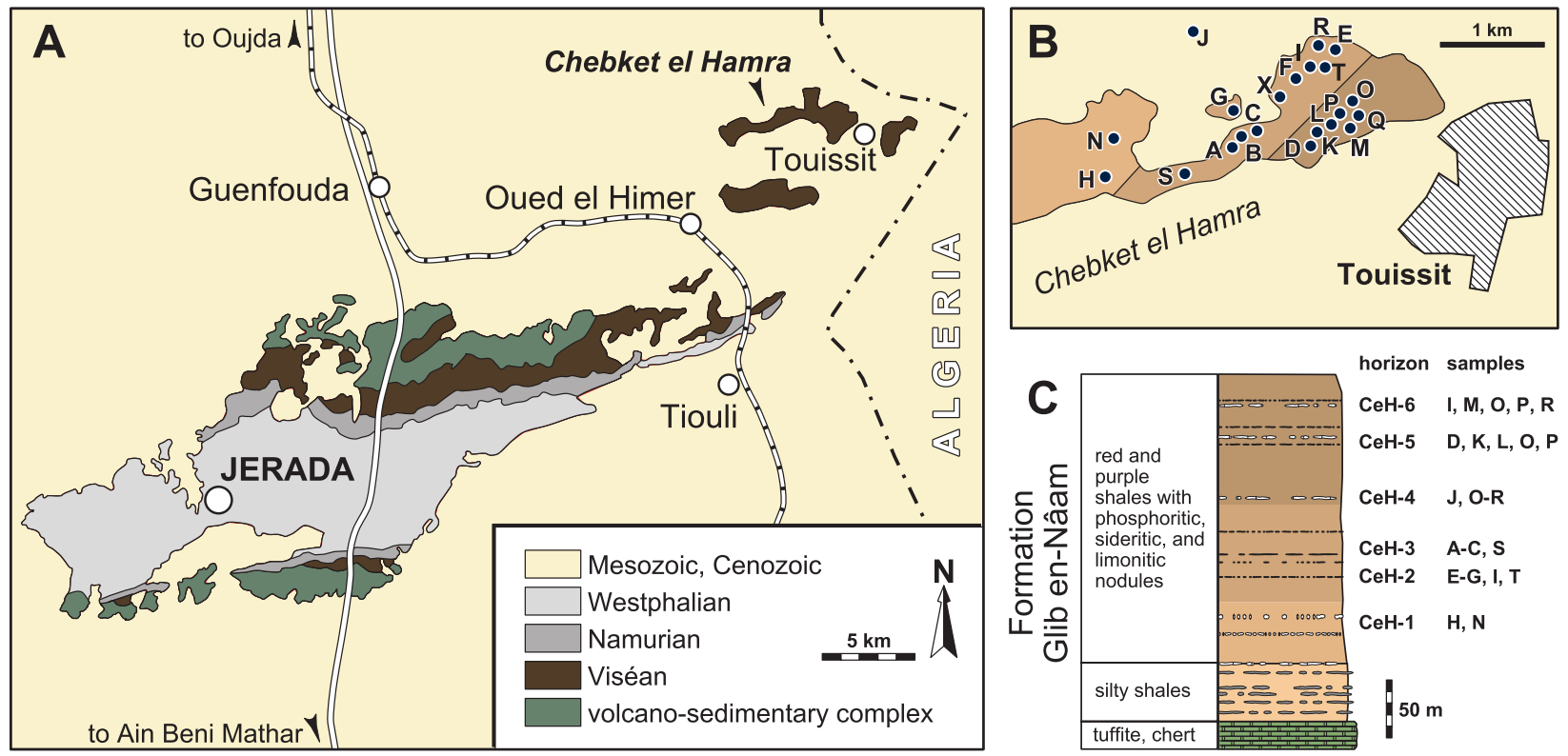

Figure 2. A. The geology of the Jerada Basin (mostly after Berkhli et al. 1999b) showing the location of the Chebket el Hamra. B. Detailed map of the Chebket el Hamra with position of the collected samples. C. Schematic columnar section with the position of the fossiliferous units and the collected samples. This figure is available in colour online at museum-fossilrecord.wiley-vch.de

silty shales with thin beds of sandstone and hard cherty nodules. These non-fossiliferous units are overlain by approximately $200 \mathrm{~m}$ of intensely weathered red and purple dark shales with phosphoritic, sideritic, and limonitic nodules and very thin limestone intercalations. This monotonous but fossiliferous succession yielded ammonoids from six clearly distinguishable units (here named $\mathrm{CeH}-1-\mathrm{CeH}-6)$, in ascending order:

CeH-1 - Hard sideritic nodules with large specimens of Goniatites crenistria Phillips, 1836 and Goniatites globostriatus (Schmidt, 1925).

CeH-2 - Intensely weathered red to purple shales with a limonitic ammonoid fauna composed of the genera Girtyoceras, Sulcogirtyoceras, Metadimorphoceras, Arnsbergites, Hibernicoceras, Paraglyphioceras, Sudeticeras, Neoglyphioceras, Praedaraelites, and Pronorites.

CeH-3 - Red shales with limonitic specimens of Eoglyphioceras, Metadimorphoceras, and Sudeticeras.

CeH-4 - Red to purple sideritic nodules with Sudeticeras.

CeH-5 - Red shales with limonitic and phosphatic nodules containing Lusitanoceras, Sudeticeras, and Lusitanites.

CeH-6 - Red shales with sideritic nodules containing Sudeticeras splendens (Bisat, 1928).

\section{Stratigraphy of the assemblages}

Stratigraphy of the Viséan ammonoid faunas from the Jerada Basin is based on the investigations by Owodenko (1946). He discovered three succeeding assemblages which based on the determinations by Delépine, he at- tributed to the German ammonoid zonation proposed by Schmidt (1925). The three zones are 'Goniatites crenistria', 'Goniatites striatus' (= various species of Arnsbergites), and 'Goniatites granosus' (=Lusitanoceras zirari). Though the identification of the latter two species is incorrect in the current state of knowledge, it can be said that the principal succession of ammonoid faunas was correctly identified and correlation with the Central European stratigraphy is corroborated by with the new study.

Owodenko (1946) mentioned two ammonoid assemblages from the Chebket el Hamra,

(1) from a locality more to the north:

'Beyrichoceras obtusum Phill.' = probably Hibernicoceras sp.

'Beyrichoceras micronotum Phill.' = probably Sudeticeras sp.

'Paraprolecanites mixolobus Sandberger' = probably Praedaraelites culmiensis

(2) from a locality more to the south:

'Goniatites falcatus Roemer.' = probably Lusitanoceras zirari

'Beyrichoceras truncatum Phill.' = probably Sudeticeras splendens.

Additionally, he mentioned one putatively Namurian specimen of 'Stenopronorites uralensis Karpinsky' not found in situ, which most probably is the Late Viséan Pronorites owodenkoi.

The spectrum of genera within the samples from the Chebket el Hamra permits an interpretation of the age of the fossiliferous horizons from the late Asbian to the late Brigantian (Late Viséan). The material is composed of genera well-known from occurrences in the Rhenohercynian and Subvariscan, represented by Eoglyphio- 


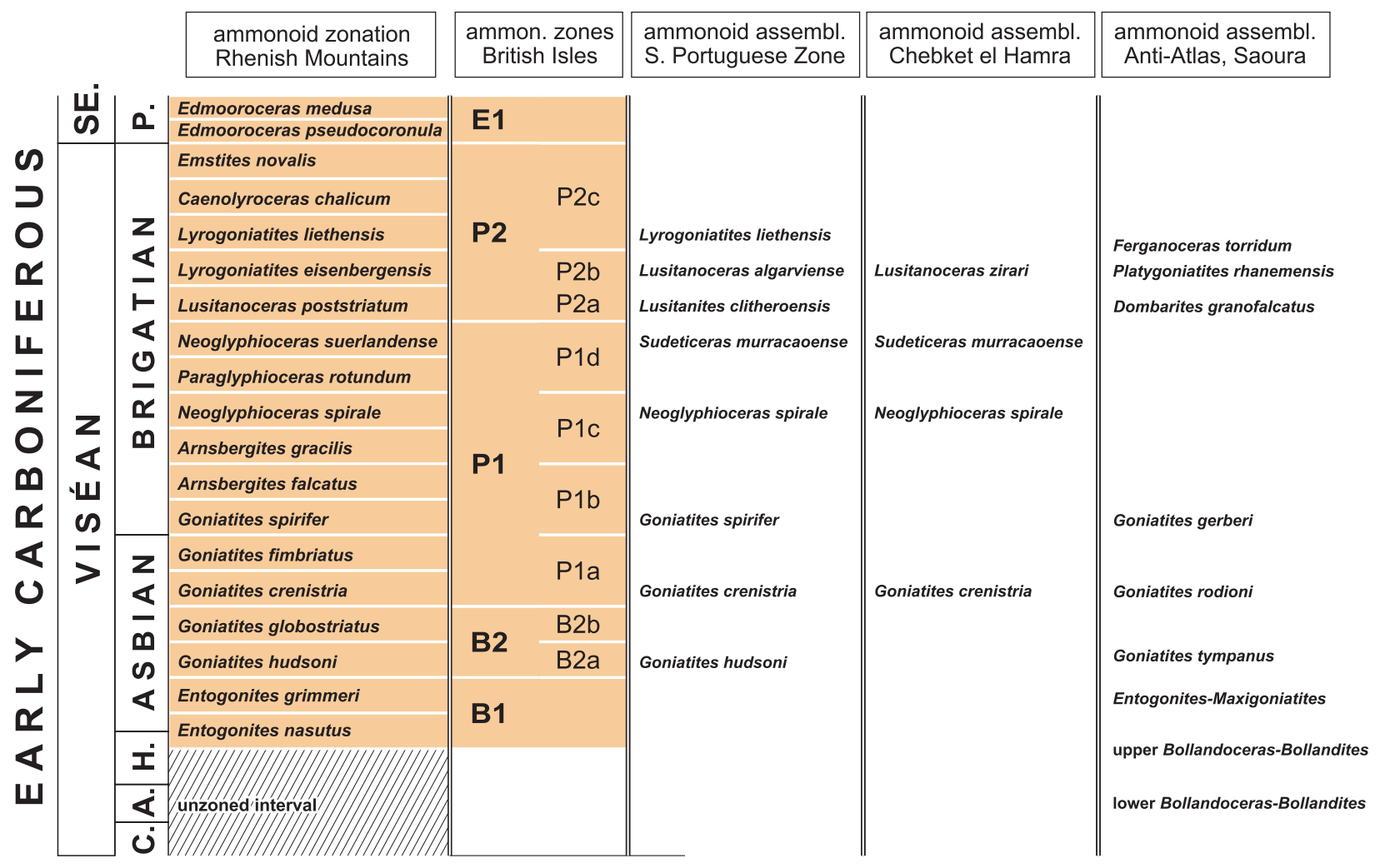

Figure 3. Stratigraphic scheme of the Late Viséan ammonoid zonation of the Rhenish Mountains and the British Isles, with correlation of the ammonoid assemblages from the South Portuguese Zone, Chebket el Hamra, and the Anti-Atlas as well as Saoura Valley. [C., Chadian; A., Arundian; H., Holkerian; SE., Serpukhovian; P., Pendleian]. This figure is available in colour online at museum-fossilrecord.wiley-vch.de

ceras, Girtyoceras, Sulcogirtyoceras, Metadimorphoceras, Goniatites, Arnsbergites, Hibernicoceras, Paraglyphioceras, Lusitanoceras, Sudeticeras, Neoglyphioceras, Lusitanites, Praedaraelites, and Pronorites. Close relationships can be detected with the ammonoid succession in the South Portuguese Zone (Korn 1997), but relationships to the ammonoid succession in places south of the High Atlas Fault are poorly known (Korn et al. 2007). The six ammonoid units of the Chebket el Hamra can be correlated as follows with the North Variscan zonations (Fig. 3):

CeH-1 - Based on the co-occurrence of Goniatites crenistria and G. globostriatus, a stratigraphic age of the basal Goniatites crenistria Zone (late Asbian) of the Rhenish Mountains is most likely (Korn 1996). Both species co-occur only at the base of this zone; G. globostriatus is not known from the widespread Crenistria Limestone at the top of the zone.

CeH-2 - The diverse assemblage with Neoglyphioceras spirale, Praedaraelites culmiensis, Hibernicoceras spp., Arnsbergites spp. etc. is known from the South Portuguese Zone (Korn 1997), north-western Ireland (Moore \& Hodson 1958), the Rhenish Mountains (Korn 1988), and the Harz (Kobold 1933). It is a very distinctive fauna of the Neoglyphioceras spirale Zone (late early Brigantian) that, within the Jerada Basin and the South Portuguese Zone, is even very similar in preservation with the pyritized or limonitic steinkern specimens.

CeH-3 - The assemblage with limonitic Sudeticeras murracaoense closely resembles the Sudeticeras murracaoense horizon in the South Portuguese Zone (Korn 1997), where that species is very abundant in one single horizon. In terms of Central European ammonoid stratigraphy (Korn 1996), it may be placed in the Neoglyphioceras suerlandense Zone (late early Brigantian).

CeH-4 - The species-poor fauna with Sudeticeras horoni was discovered a few metres above the previous assemblage, and mixing is seen in some places. An equivalent is not known from other regions. It may belong in the Neoglyphioceras suerlandense Zone of the Rhenish Mountains (late early Brigantian).

CeH-5 - The co-occurrence of Lusitanoceras and Lusitanites speaks for an attribution in the Lusitanoceras poststriatum Zone of the Rhenish Mountains that corresponds to the P2a Zone of the British Isles (late Brigantian). The specific composition of unit 5 allows a correlation with the South Portuguese Zone, where both genera occur, if not together then in an interval of two metres.

CeH-6 - Sudeticeras splendens (Bisat, 1928) suggests an attribution in the Lyrogoniatites liethensis Zone of the Rhenish Mountains that corresponds to the higher P2 (late Brigantian). 
Faunas from the late Asbian (Goniatites crenistria), the early Brigantian (Neoglyphioceras spirale together with species of Arnsbergites and Hibernicoceras), and the late Brigantian (Lusitanoceras zirari) occur in the same rock unit, thus raising strong doubts concerning the interpretation of separate major cycles, as done by Berkhli et al. (1999b).

\section{Material}

More than 1,200 specimens from 21 different localities (each representing one sample) at the Chebket el Hamra were available for study. Principally, two different modes of preservation are represented in the material:

- Sideritic nodules (stratigraphic units CeH-1, CeH-3, CeH-6). Ammonoids from these nodules reach sizes of almost $10 \mathrm{~cm}$, and are usually preserved as steinkerns with shell remains sometimes attached. Inner whorls are rarely preserved; usually only the body chamber was filled by sediment whereas the phragmocone imploded during diagenesis.

- Limonitic (or goethitic) preservation (stratigraphic units $\mathrm{CeH}-2$, $\mathrm{CeH}-4, \mathrm{CeH}-5)$. These ammonoid conchs are usually much smaller with a maximum diameter of $40 \mathrm{~mm}$; normally only the phragmocone is preserved.

About 100 cross sections of most of the species were produced to allow the investigation of the inner whorls as well as separation and attribution of the juvenile specimens.

\section{Systematic descriptions}

Descriptive terms of the conch features are adopted from Korn (1988); abbreviations of the conch dimensions (Fig. 4) are: conch diameter (dm), whorl width (ww), whorl height (wh), umbilical width (uw), and aperture height (ah).
Conch shapes are described as follows:

- thinly discoidal: $\quad$ ww $/ \mathrm{dm}<0.36$

- discoidal: $\quad \mathrm{ww} / \mathrm{dm}=0.36-0.60$;

- pachyconic: $\quad \mathrm{ww} / \mathrm{dm}=0.61-0.85$;

- globular: $\quad \mathrm{ww} / \mathrm{dm}=0.86-1.10$.

Conch dimensions are subdivided as follows:

- small: $\quad \mathrm{dm}<30 \mathrm{~mm}$

- moderate: $\quad \mathrm{dm}=31-70 \mathrm{~mm}$;

- moderately large: $\mathrm{dm}=71-120 \mathrm{~mm}$;

- large: $\quad \mathrm{dm}>120 \mathrm{~mm}$.

The width of the umbilicus, relative to the diameter of the conch, is termed as follows:

- very narrow: $\quad \mathrm{uw} / \mathrm{dm}<0.16$;

- narrow: $\quad \mathrm{uw} / \mathrm{dm}=0.16-0.30$;

- moderately wide: $\quad \mathrm{uw} / \mathrm{dm}=0.31-0.45$;

- wide: $\quad \mathrm{uw} / \mathrm{dm}=0.46-0.60$;

- very wide: $\quad u w / d m>0.60$.

A very important conch parameter is the whorl expansion rate (WER). It can be calculated by the algorithm used by Korn (2000): $\mathrm{WER}=[\mathrm{dm} /(\mathrm{dm}-\mathrm{ah})]^{2}$. The imprint zone rate $(\mathrm{IZR})$ is a ratio that characterises the whorl overlap. It can be calculated by the following equation: $I Z R=(w h-a h) / w h$.

The direction and the course of the growth lines are defined as:

- rursiradiate: turning back on the flanks;

- rectiradiate: running approximately radially;

- prorsiradiate: projecting on the flanks;

- linear: without remarkable projections and sinuses;

- convex: with only one lateral projection and a ventral sinus;

- concavo-convex: with a lateral sinus, a ventrolateral projection, and a ventral sinus;

- biconvex: with a dorsolateral and a ventrolateral projection, and a lateral as well as a ventral sinus.

Sutural terminology (Fig. 4) is according to Wedekind (1918), and Korn et al. (2003):

- external lobe (E lobe);

- median saddle (M saddle);
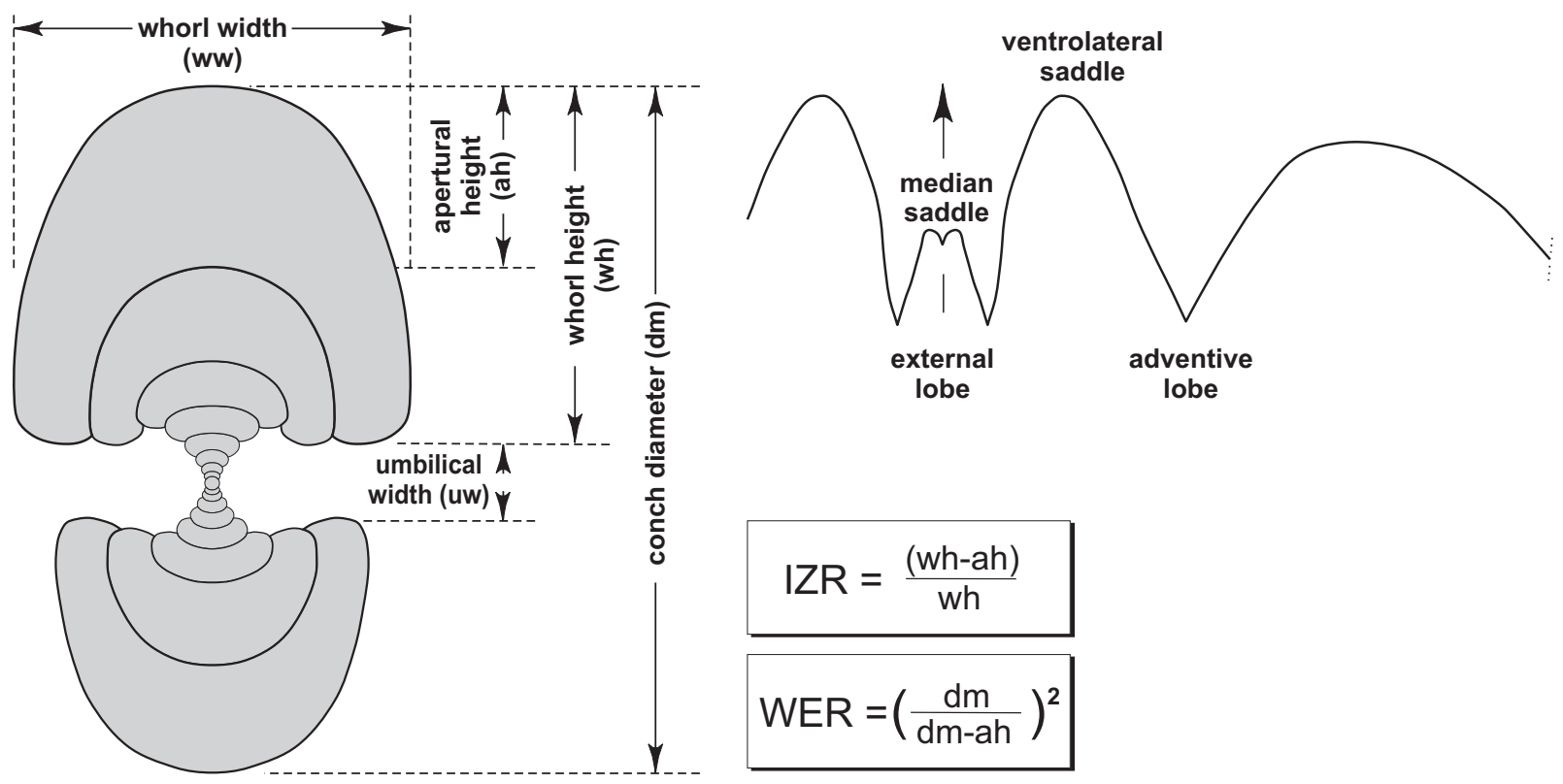

Figure 4. Conch and suture line parameters and ratios as used in the descriptions of the ammonoid species. 
- ventrolateral saddle (E/A saddle; between external lobe and adventive lobe);

- adventive lobe (A lobe);

- dorsolateral saddle (A/L saddle; between adventive lobe and lateral lobe);

- lateral lobe (L lobe);

- umbilical lobe (U lobe);

- internal lobe (I lobe).

Especially in Carboniferous ammonoids, the shape of the external lobe is an important criterion for distinguishing higher-rank ammonoid taxa and also for species of one genus. Its general shape is described as follows:

- rectangular: with largely parallel, almost uncurved flanks;

- pouched or inflated: with more or less parallel, convexly curved flanks;

- V-shaped: with diverging, almost straight flanks;

- Y-shaped: with flanks parallel in the lower part, but diverging in the upper part.

The width of the external lobe, which is an important criterion for the separation of species and genera particularly of the Goniatitina, can be described (1) by the ratio of the width (at half depth) of the external lobe and the adventive lobe (E/A as used by Korn 1988), or (2) by the ratio of width (measured at half depth) and total depth of the external lobe (EL/h as used by Korn 1997).

The width of the external lobe is classified follows:

$\begin{array}{ll}\text { - very narrow: } & \mathrm{E} / \mathrm{A}<0.50 \\ \text { - narrow: } & \mathrm{E} / \mathrm{A}=0.50-0.75 \\ \text { - moderately narrow: } & \mathrm{E} / \mathrm{A}=0.75-1.00 \\ \text { - moderate: } & \mathrm{E} / \mathrm{A}=1.00-1.25 \\ \text { - moderately wide: } & \mathrm{E} / \mathrm{A}=1.25-1.50 \\ \text { - wide: } & \mathrm{E} / \mathrm{A}=1.50-1.75 \\ \text { - very wide: } & \mathrm{E} / \mathrm{A}>1.75\end{array}$

The height of the median saddle is measured by its ratio with the depth of the external lobe $(\mathrm{MS} / \mathrm{h})$ :

$\begin{array}{ll}\text { - very low: } & \mathrm{MS} / \mathrm{h}<0.20 \\ \text { - low: } & \mathrm{MS} / \mathrm{h}=0.20-0.35 \\ \text { - moderate: } & \mathrm{MS} / \mathrm{h}=0.35-0.50 \\ \text { - moderately high: } & \mathrm{MS} / \mathrm{h}=0.50-0.65 \\ \text { - high: } & \mathrm{MS} / \mathrm{h}=0.65-0.80 \\ \text { - very high: } & \mathrm{MS} / \mathrm{h}>0.80\end{array}$

The material described and figured in the following account is stored in the following collections:

Museum für Naturkunde der Humboldt-Universität zu Berlin (MB.C.prefix), British Museum (Natural History), London (NHM prefix), Geological Survey Museum, Keyworth, Nottinghaum (GSM prefix), Instituto Geológico e Mineiro, Lisboa (IGML prefix), Westfälisches Museum für Naturkunde, Münster (WMN prefix).
Order Goniatitida Hyatt, 1884

Suborder Goniatitina Hyatt, 1884

Superfamily Muensteroceratoidea Librovitch, 1957

Family Muensteroceratidae Librovitch, 1957

\section{Eoglyphioceras Brüning, 1923}

Type species. Goniatites truncatus Phillips, 1836.

Discussion. The problem regarding the taxonomic validity of the two genera Eoglyphioceras Brüning, 1923 and Beyrichoceratoides Bisat, 1924 is not fully resolved. Korn (1988) treated Eoglyphioceras as valid, whereas Riley (1996) regarded it as an invalid genus. This latter opinion was mainly based on the arguments that no type species was given for Eoglyphioceras, and that this genus was defined by amalgamation of Beyrichoceras and Muensteroceras.

Currently, nine species can be attributed with more or less certainty to Eoglyphioceras (Korn \& Ilg, 2007). Several of these require revision to make clear that they really belong to this genus.

The better known Western and Central European species of Eoglyphioceras can be grouped as follows:

A - species with a large conch (reaching $50 \mathrm{~mm}$ in diameter or more):

E. truncatum (Phillips, 1836): with delicate radial ornament;

E. redesdalense (Hind, 1918): with coarse radial ornament and pachyconic conch;

E. fournieri (Delépine, 1940): with coarse radial ornament and discoidal conch.

B - species with a small conch (reaching $30 \mathrm{~mm}$ in diameter or less):

E. serotinum Korn, 1997: with few constrictions and delicate radial ornament;

E. minutum n. sp.: with numerous constrictions.

\section{Eoglyphioceras minutum n. sp.}

Figures 5-6

Derivation of name. After Latin minutus $=$ minute, because of the small conch.

Holotype. Specimen MB.C.13269.1 (Ebbighausen \& Weyer 2007 Coll.); illustrated in Figure 5A.
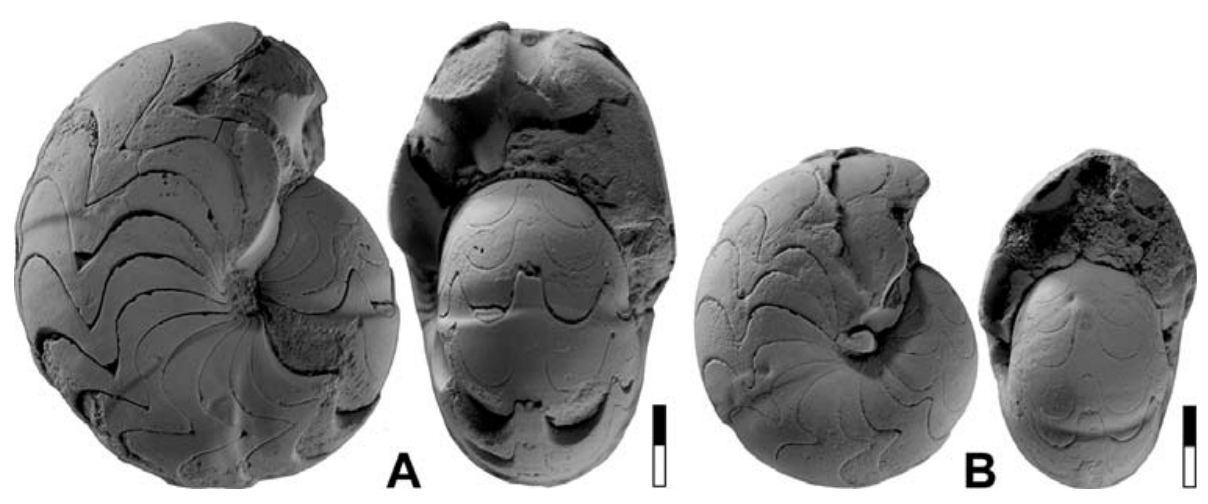

Figure 5. Eoglyphioceras minutum n. sp. A. Holotype MB.C.13269.1 from locality Chebket el Hamra-S; $\times 4.0$. B. Paratype MB.C.13269.3 from locality Chebket el Hamra-S; $\times 4.0$. 


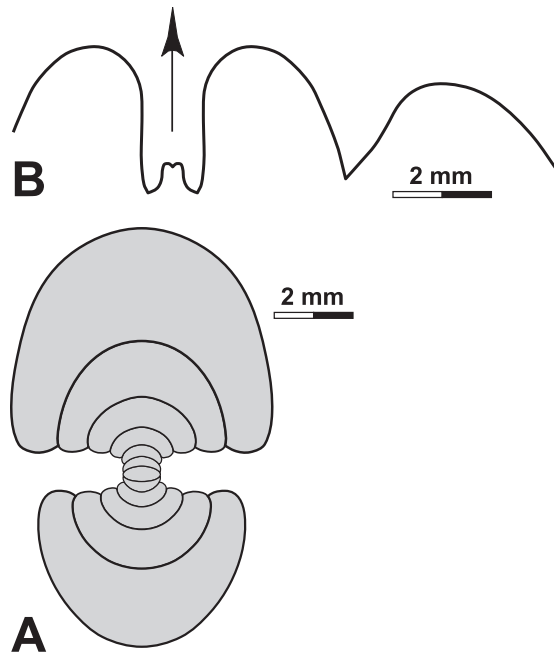

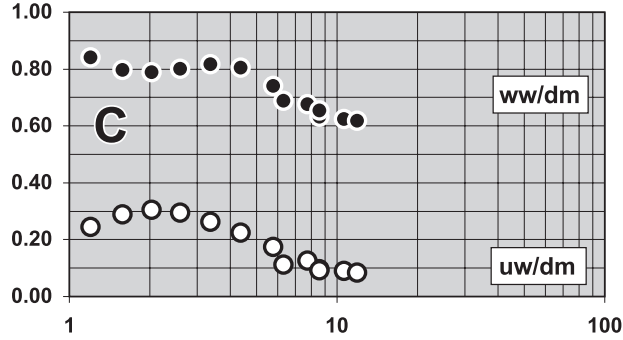

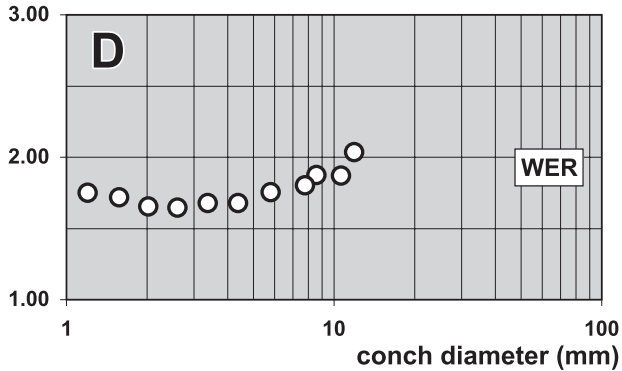

Figure 6. Eoglyphioceras minutum n. sp. A. Cross section of paratype MB.C.13269.2 from locality Chebket el Hamra-S; $\times 4.0$. B. Suture line of paratype MB.C.13269.1 from locality Chebket el Hamra-S, at $11.5 \mathrm{~mm} \quad \mathrm{dm}, \quad 7.0 \mathrm{~mm}$ ww, $6.5 \mathrm{~mm}$ wh; $\times 5.0$. C, D. Ontogenetic development of the conch width index (ww/dm), umbilical width index (uw/dm) and whorl expansion rate (WER) of all available specimens.
Type locality and horizon. Chebket el Hamra-S (Jerada Basin, NEMorocco); horizon CeH-4 (middle Brigantian, Early Carboniferous).

Material. Three limonitic steinkern specimens of phragmocones between 8.5 and $12 \mathrm{~mm}$ conch diameter from horizon $\mathrm{CeH}-4$ at locality Chebket el Hamra-S.

Diagnosis. Small Eoglyphioceras with thinly pachyconic conch at $6 \mathrm{~mm}$ diameter $(\mathrm{ww} / \mathrm{dm}=0.70)$ and thickly discoidal to thinly pachyconic conch at $12 \mathrm{~mm}$ diameter $(\mathrm{ww} / \mathrm{dm}=0.60)$. Umbilicus very narrow between $8 \mathrm{~mm}$ and $12 \mathrm{~mm} \mathrm{dm}(\mathrm{uw} / \mathrm{dm}=0.10)$; umbilical margin broadly rounded. Internal mould with numerous constrictions, which extend almost straight across the flanks and form a shallow ventral sinus. Suture line with slightly pouched, very narrow external lobe ( 0.40 of the external lobe depth, 0.90 of the adventive lobe), and very low median saddle ( 0.20 of the external lobe depth). Ventrolateral saddle broadly rounded, adventive lobe V-shaped with almost uncurved flanks.

Description. The ontogenetic development is displayed by the sectioned paratype MB.C.13269.2 (10.6 mm dm; Fig. 6A), which shows the thickly pachyconic inner whorls $(\mathrm{ww} / \mathrm{dm}=0.80$ at $1.5-4.5 \mathrm{~mm} \mathrm{dm})$ with opened umbilicus (uw/dm $=0.30$ at $2 \mathrm{~mm} \mathrm{dm}$ ) and the trend toward a slender conch $(\mathrm{ww} / \mathrm{dm}=0.62$ at $10.6 \mathrm{~mm}$ $\mathrm{dm})$ with very narrow umbilicus $(\mathrm{uw} / \mathrm{dm}=0.09)$. The conch is laterally compressed at this stage with subparallel flanks and a broadly rounded venter; the umbilical margin is rounded. During ontogeny, there is a slight increase in apertural height (WER $=1.65$ at $2 \mathrm{~mm} \mathrm{dm}$ and 1.87 at $10.6 \mathrm{~mm} \mathrm{dm}$ ).

Holotype MB.C.13269.1 is the largest of the three specimens; it has a thinly pachyconic shape (ww/ $\mathrm{dm}=0.62$ ) and a very narrow umbilicus (uw/ $\mathrm{dm}=0.08$ ) at $12 \mathrm{~mm}$ diameter (Fig. 5A). Its umbilical margin is broadly rounded, and the flanks converge slowly towards the broadly rounded venter. It is a fully septate specimen with nearly 20 chambers on the last volution and does not show any details of ornament. The internal mould is decorated with five almost regularly positioned constrictions; they run almost linearly across the flanks and turn back for a shallow ventral sinus.
The smaller specimen MB.C.13269.3 (8.5 mm dm) has a slightly thicker conch $(\mathrm{ww} / \mathrm{dm}=0.63)$ and also otherwise closely resembles the larger specimen (Fig. 5B). The smaller one has only three irregularly arranged constrictions with almost straight course.

The suture line of the largest specimen, holotype MB.C.13269.1 (drawn at $11.5 \mathrm{~mm}$ conch diameter), has a narrow rectangular, slightly pouched external lobe with flanks that are almost parallel in the lower three quarters, and diverge then strongly to form a broadly rounded ventrolateral saddle (Fig. 6B). This appears inclined toward the venter and continues into the simple V-shaped adventive lobe, which has weakly curved flanks.

Discussion. E. serotinum Korn, 1997 is a similar, smallsized species with a slightly wider umbilicus at comparable stages. However, the numerous constrictions of E. minutum clearly separate this new species from E. serotinum.

Superfamily Girtyoceratoidea Wedekind, 1918

Family Girtyoceratidae Wedekind, 1918

\section{Girtyoceras Wedekind, 1918}

Type species. Adelphoceras meslerianum Girty, 1909.

Discussion. Girtyoceras is a genus with a nearly global distribution and 28 possibly valid species are listed in the AMMON database (Korn \& Ilg 2007). Some of these species are based on insufficiently preserved material and may not belong to this genus. Sixteen of the species were erected on material from Europe, and only few of these were described with respect to ontogenetic development of conch geometry and ornament. The various species of Girtyoceras however, can only be defined when ontogenetic series are available; separation of the species requires the comparison of specimens of the same size. The following key to the European species must remain incomplete because of the lack of information for some species. 
The better known Western and Central European species of Girtyoceras can be grouped as follows:

A - species with a discoidal conch $(\mathrm{ww} / \mathrm{dm}=$ less than 0.50 at $15 \mathrm{~mm}$ conch diameter):

G. ibergense Korn, 1992 (in Gischler \& Korn 1992): slender form $(\mathrm{ww} / \mathrm{dm}=0.45, \mathrm{uw} / \mathrm{dm}=0.13$ at $16 \mathrm{~mm} \mathrm{dm}$ ) with weakly biconvex constrictions, sharpening of the venter above $35 \mathrm{~mm}$ conch diameter;

G. brueningianum (Schmidt, 1925): very slender form $(\mathrm{ww} / \mathrm{dm}=0.37, \mathrm{uw} / \mathrm{dm}=0.18$ at $16 \mathrm{~mm}$ $\mathrm{dm}$ ) with biconvex constrictions and feeble ribs around the umbilicus, sharpening of the venter above $24 \mathrm{~mm}$ conch diameter;

G. Iuscinia Korn, 1988: slender form (ww/ $\mathrm{dm}=0.45$, uw $/ \mathrm{dm}=0.20$ at $15 \mathrm{~mm} \mathrm{dm}$ ) with biconvex constrictions and with faint riblets around the umbilicus, sharpening of the venter above $20 \mathrm{~mm}$ conch diameter;

G. ibnkhaldouni n. sp.: slender form $(\mathrm{ww} / \mathrm{dm}=0.45$, $\mathrm{uw} / \mathrm{dm}=0.15$ at $15 \mathrm{~mm} \mathrm{dm}$ ) with biconvex constrictions and with faint riblets around the umbilicus, sharpening of the venter above $15 \mathrm{~mm}$ conch diameter;

G. goii Korn, 1988: slender form $(\mathrm{ww} / \mathrm{dm}=0.50$, $\mathrm{uw} / \mathrm{dm}=0.12$ at $16 \mathrm{~mm} \mathrm{dm}$ ) with biconvex constrictions and without ribs, sharpening of the venter above $18 \mathrm{~mm}$ conch diameter;

G. deani Moore, 1946: very slender form (ww/ $\mathrm{dm}=0.27$, uw $/ \mathrm{dm}=0.14$ at $22 \mathrm{~mm} \mathrm{dm}$ ) without constrictions and without ribs, sharpening of the venter above $22 \mathrm{~mm}$ conch diameter;

G. simplex Moore, 1946: slender form (ww/ $\mathrm{dm}=0.38, \mathrm{uw} / \mathrm{dm}=0.14$ at $29 \mathrm{~mm} \mathrm{dm}$ ) with concavo-convex constrictions and without ribs, sharpening of the venter above $24 \mathrm{~mm}$ conch diameter;

G. premeslerianum Moore, 1946: slender form (ww/ $\mathrm{dm}=0.44 ; \mathrm{uw} / \mathrm{dm}=0.18$ at $18 \mathrm{~mm} \mathrm{dm}$ ) with concavo-convex constrictions and without ribs, sharpening of the venter above $25 \mathrm{~mm}$ conch diameter, fine spiral lines.
B - species with a thickly discoidal or pachyconic conch $(\mathrm{ww} / \mathrm{dm}=$ more than 0.50 at $15 \mathrm{~mm}$ conch diameter):

G. duekemoerense Korn, 1988: rather stout form $(\mathrm{ww} / \mathrm{dm}=0.53, \mathrm{uw} / \mathrm{dm}=0.20$ at $16 \mathrm{~mm} \mathrm{dm})$ with concavo-convex constrictions and rather strong ribs on the flanks, sharpening of the venter above $16 \mathrm{~mm}$ conch diameter;

G. margaritatum Korn, 1988: rather stout form (ww/ $\mathrm{dm}=0.55, \mathrm{uw} / \mathrm{dm}=0.14$ at $16 \mathrm{~mm} \mathrm{dm}$ ) with very weak constrictions and without ribs, sharpening of the venter above $15 \mathrm{~mm}$ conch diameter;

G. aeulkei Korn, 1988: rather stout form (ww/ $\mathrm{dm}=0.58, \mathrm{uw} / \mathrm{dm}=0,07$ at $16 \mathrm{~mm} \mathrm{dm}$ ) with biconvex constrictions and rather strong ribs on the flanks;

G. edwinae Korn, 1988: stout form ( $\mathrm{ww} / \mathrm{dm}=0.65$, $\mathrm{uw} / \mathrm{dm}=0.26$ at $14 \mathrm{~mm} \mathrm{dm}$ ) with concavo-convex constrictions and without ribs;

G. shorrocksi Moore, 1946: rather stout form (ww/ $\mathrm{dm}=0.54, \quad \mathrm{uw} / \mathrm{dm}=0.21$ at $17 \mathrm{~mm} \mathrm{dm}$ ) with sharp ribs;

G. waitei Moore, 1946: stout form $(\mathrm{ww} / \mathrm{dm}=0.63$, $\mathrm{uw} / \mathrm{dm}=0.16$ at $16 \mathrm{~mm} \mathrm{dm}$ ) with sharp ribs, sharpening of the venter above $20 \mathrm{~mm}$ conch diameter.

\section{Girtyoceras luscinia Korn, 1988 \\ Figures 7-8}

1988 Girtyoceras luscinia Korn, p. 52, pl. 7, figs 5-8.

1997 Girtyoceras luscinia. - Korn, p. 44, pl. 3, figs 5, 6.

Holotype. Specimen WMN 10028 (Rademacher Coll.); figured by Korn (1988, pl. 7, figs 5, 6).

Type locality and horizon. Large quarry north of Deinstrop near Holzen (Rhenish Mountains); Arnsbergites gracilis Zone (Late Viséan).

Material. Five limonitic steinkern specimens of phragmocones between 8.5 and $20.5 \mathrm{~mm}$ conch diameter from horizon $\mathrm{CeH}-2$ at localities Chebket el Hamra-F and G.

Diagnosis. Girtyoceras with thickly discoidal, moderately umbilicate conch at $10 \mathrm{~mm}$ diameter $(\mathrm{ww} / \mathrm{dm}=0.55 ; \mathrm{uw} / \mathrm{dm}=0.30)$ and thinly discoidal, narrowly umbilicate conch at $20 \mathrm{~mm}$ diameter (ww/
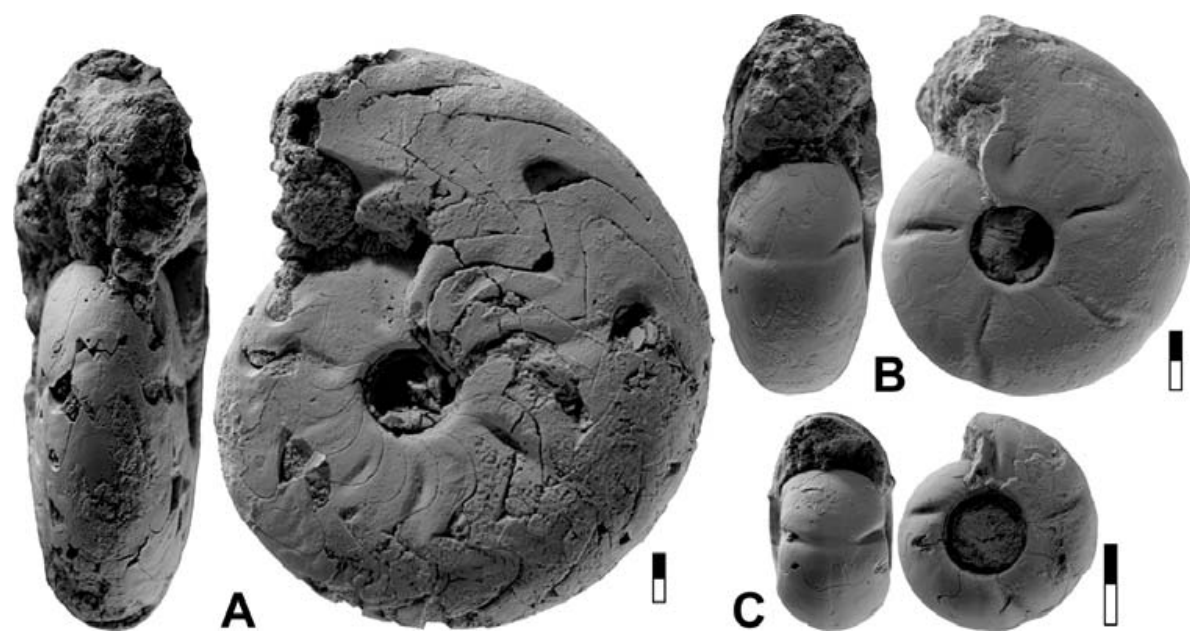

Figure 7. Girtyoceras luscinia Korn, 1988. A. Specimen MB.C.13213.1 from locality Chebket el Hamra-F; $\times 2.5$. B. Specimen MB.C.13213.2 from locality Chebket el Hamra-F; $\times 3.0$. C. Specimen MB.C.13213.3 from locality Chebket el Hamra-F; $\times 4.0$. 


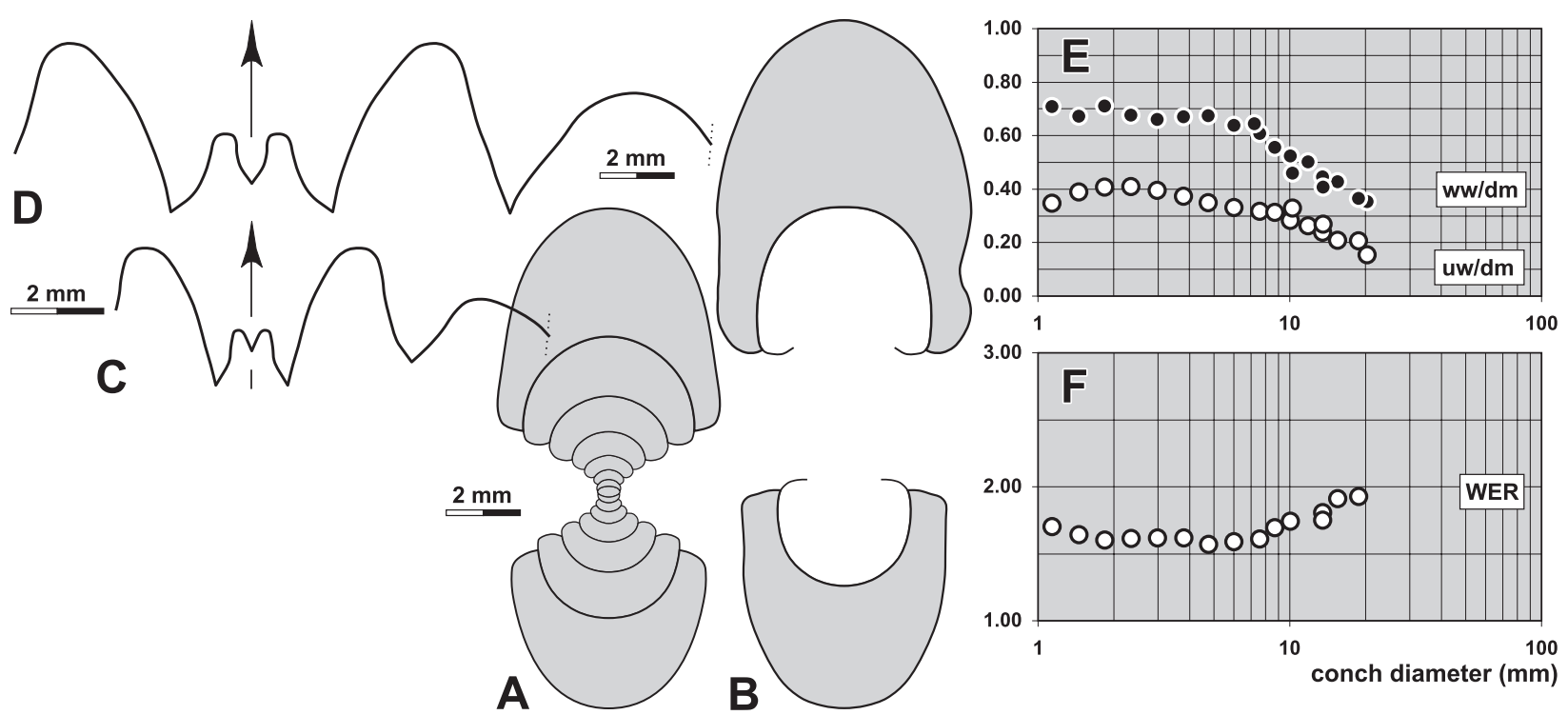

Figure 8. Girtyoceras luscinia Korn, 1988. A. Cross section of specimen MB.C.13213.4 from locality Chebket el Hamra-F; $\times 4.0$. B. Cross section of specimen MB.C.13228 from locality Chebket el Hamra-G; × 4.0. C. Suture line of specimen MB.C.13213.2 from locality Chebket el Hamra-F, at $13.6 \mathrm{~mm} \mathrm{dm}, 5.8 \mathrm{~mm}$ ww, $6.2 \mathrm{~mm}$ wh; $\times 5.0$. D. Suture line of specimen MB.C.13213.1 from locality Chebket el Hamra-F, at $21.7 \mathrm{~mm} \mathrm{dm}, 7.6 \mathrm{~mm}$ ww, $11.5 \mathrm{~mm}$ wh; $\times 5.0$. E, F. Ontogenetic development of the conch width index (ww/dm), umbilical width index (uw/dm) and whorl expansion rate (WER) of all available specimens.

$\mathrm{dm}=0.35 ; \mathrm{uw} / \mathrm{dm}=0.15)$. Umbilical wall angular. Venter rounded up to $15 \mathrm{~mm} \mathrm{dm}$; sharpening of the venter begins at $20 \mathrm{~mm} \mathrm{dm}$. Internal mould in the immature stage with biconvex and rectiradiate constrictions with low dorsolateral projection and higher ventrolateral projection; external sinus shallow. Juveniles with faint, short riblets around the umbilicus.

Description. The sectioned specimen MB.C.13213.4 shows the development of all whorls up to $13.5 \mathrm{~mm}$ conch diameter (Fig. 8A). Two growth stages can be separated, the first (up to $8 \mathrm{~mm} \mathrm{dm}$ ) in which growth of the conch is almost isometric, being thinly pachyconic $(\mathrm{ww} / \mathrm{dm}=0.65-0.70)$ with a moderately wide umbilicus (uw/dm $=0.33-0.41)$ with a crescent-shaped whorl cross section. The aperture is low in this growth interval $($ WER $=1.60-1.65)$. In the second stage, the conch becomes continuously more slender, with a ww/dm ratio of 0.44 at $13.5 \mathrm{~mm} \mathrm{dm}$, parallel to narrowing of the umbilicus (uw/dm $=0.24$ ) and heightening of the aperture $($ WER $=1.80)$. The umbilical margin is rounded in the first stage and becomes subangular in the second.

Specimen MB.C.13213.1 is a somewhat corroded but otherwise well preserved steinkern specimen of $20 \mathrm{~mm}$ diameter (Fig. 7A). It is fully chambered and demonstrates the transition from the immature stage with distinct constrictions to the adult oxyconic stage. The conch is thinly discoidal and narrowly umbilicate (ww/ $\mathrm{dm}=0.35 ; \quad \mathrm{uw} / \mathrm{dm}=0.16$ ) with slowly converging flanks towards a narrow and later slightly keeled venter. The umbilicus is angular on the first half of the last whorl and becomes rounded in the second half. The first three quarters of the last volution display eight radial constrictions, which become continuously shallower with increasing size of the specimen. They are restricted to the flanks and form a shallow lateral sinus and a rather high ventrolateral salient. Faint and rounded riblets can be seen between the constrictions.

The characteristic morphology of the species is better expressed by specimen MB.C.13213.2 (15 mm dm), in which the conch is discoidal $(\mathrm{ww} / \mathrm{dm}=0.43)$ with a narrow umbilicus (uw $/ \mathrm{dm}=0.21$ ) that is separated from the flanks by an angular margin (Fig. 7B). The last volution shows five regularly arranged steinkern constrictions, which begin in a short distance from the umbilical margin. The last three volutions form a low dorsolateral projection, a higher ventrolateral projection, and a rather shallow ventral sinus. A dorsolateral projection is not developed in the early two constrictions.

Specimen MB.C.13213.3 (8.5 $\mathrm{mm} \mathrm{dm})$ shows the juvenile morphology with a thickly discoidal, moderately umbilicate conch $(\mathrm{ww} / \mathrm{dm}=0.56 ; \mathrm{uw} / \mathrm{dm}=0.31)$. It has a rather sharp umbilical edge on which faint short riblets occur. Three steinkern constrictions are present; these run in prorsiradiate direction across flanks and venter and form a wide ventral projection (Fig. 7C).

The suture line of specimen MB.C.13213.1 (21.7 mm $\mathrm{dm})$ can be regarded as typical for an adult specimen of Girtyoceras (Fig. 8D). It possesses a very wide Vshaped external lobe, subdivided by a moderately high median saddle, with asymmetric prongs. The ventrolateral saddle is asymmetric and dorsally inclined, and the adventive lobe is as deep as the external lobe and Vshaped.

The smaller specimen MB.C.13213.2 (13.6 mm dm) has a suture line that is characteristic of the premature stage (Fig. 8C). Its external lobe is V-shaped with strongly diverging flanks, the ventrolateral saddle is asymmetric and rounded, and the small adventive lobe is V-shaped. 
Discussion. The material is very similar to that described by Korn $(1988,1997)$ from the Rhenish Mountains and the South Portuguese Zone. Probably owing to the same type of preservation the latter can be regarded identical in conch morphology and ornament.

The co-occurring G. ibnkhaldouni is generally similar but differs in the narrower umbilicus at the same conch diameters (uw $/ \mathrm{dm}=0.28$ in G. luscinia but 0.20 in G. ibnkhaldouni at $10 \mathrm{~mm}$ conch diameter). Furthermore, G. luscinia has more strongly curved constrictions and develops an acute venter at larger diameters (at $20 \mathrm{~mm}$ in G. luscinia but $15 \mathrm{~mm}$ in G. ibnkhaldouni).

Some of the stratigraphically older species of Girtyoceras are rather similar, such as G. brueningianum (but with a more slender conch and stronger curved constrictions), G. ibergense (but with a much narrower umbilicus and a much later beginning oxyconic stage), and $G$. deani as well as $G$. simplex (but with a much more slender conch).

\section{Girtyoceras ibnkhaldouni n. sp.}

Figures 9-10

Derivation of name. After Ibn Khaldoun (1332-1406), one of the most influential Arab philosophers of medieval times.

Holotype. Specimen MB.C.13214.1 (Korn \& Ebbighausen 2006 Coll.); illustrated in Figure 9A.

Type locality and horizon. Chebket el Hamra-F (Jerada Basin, NEMorocco); horizon $\mathrm{CeH}-2$, probably Neoglyphioceras spirale Zone (middle Brigantian, Early Carboniferous).

Material. Nine limonitic steinkern specimens with conch diameters between 5 and $18 \mathrm{~mm}$ from horizon $\mathrm{CeH}-2$ at localities Chebket el Hamra-F and G.

Diagnosis. Girtyoceras with discoidal, narrowly umbilicate conch at $10 \mathrm{~mm}$ diameter $(\mathrm{ww} / \mathrm{dm}=0.50 ; \mathrm{uw} / \mathrm{dm}=0.20)$ and thinly discoidal conch, narrowly umbilicate conch at $15 \mathrm{~mm}$ diameter (ww/ $\mathrm{dm}=0.45 ; \quad \mathrm{uw} / \mathrm{dm}=0.15)$. Umbilical wall subangular. Venter rounded up to $12 \mathrm{~mm} \mathrm{dm}$; sharpening of the venter begins at $15 \mathrm{~mm}$ $\mathrm{dm}$. Internal mould in the immature stage with slightly biconvex and rectiradiate constrictions with low dorsolateral projection and low ventrolateral projection; external sinus very shallow. Juveniles with faint short riblets around the umbilicus.

Description. The sectioned paratype MB.C.13214.4 shows ontogenetic changes consisting of a first growth stage that ends at $6 \mathrm{~mm}$ and a second ranging from 6 to
$18 \mathrm{~mm}$ conch diameter (Fig. 10B). The first stage is characterised by an almost stable ww/dm ratio $(0.60-$ 0.70 ) and a low aperture (WER $=1.55-1.68)$. At $6 \mathrm{~mm}$ $\mathrm{dm}$, there is a continuous heightening of the aperture (WER higher than 2.00 at $10 \mathrm{~mm} \mathrm{dm}$ ), paralleled by a lowering of the whorl width/conch diameter ratio (ww/ $\mathrm{dm}=0.42$ at $18 \mathrm{~mm} \mathrm{dm}$ ). The development of the umbilicus is uncoupled from the other two characters; it is widest at $2 \mathrm{~mm} \mathrm{dm}(\mathrm{uw} / \mathrm{dm}=0.45)$ and becomes narrower towards a value of only 0.13 at $18 \mathrm{~mm} \mathrm{dm}$. The early stage shows semilunate whorl cross sections, becoming laterally compressed at $6 \mathrm{~mm} \mathrm{dm}$, with the development of a subangular umbilical margin.

Holotype MB.C.13214.1, with a diameter of $21 \mathrm{~mm}$, is the largest specimen of this species, but the last quarter of its whorl is crushed (Fig. 9A). It is discoidal at $15 \mathrm{~mm} \mathrm{dm}(\mathrm{ww} / \mathrm{dm}=0.45)$ with a narrow umbilicus (uw/dm $=0.15$ ), a subangular umbilical wall, and a narrowly rounded venter. The last volution has five shallow steinkern constrictions, of which the last two are only elongate notches on the inner flank. The constrictions at the beginning of the last volution are biconvex with a rather high ventrolateral projection and a rather deep ventral sinus.

The immature morphology can be studied in paratype MB.C.13214.2 (10 mm dm; Fig. 9B). It is discoidal $(\mathrm{ww} / \mathrm{dm}=0.50)$ with a narrow umbilicus (uw/ $\mathrm{dm}=0.17)$. The flanks converge slowly towards the narrowly rounded venter and the umbilical margin is subangular. The steinkern shows four constrictions standing $90^{\circ}$ apart. They begin a short distance from the umbilicus, extend in linear direction across the inner flanks, bending forward to form a low ventrolateral projection and a very shallow ventral sinus.

The suture line of holotype MB.C.13214.1 has, at almost $16 \mathrm{~mm}$ conch diameter, a wide external lobe subdivided by a moderately high median saddle (Fig. 10C). The flanks of the external lobe are concavely incurved and continue into the asymmetric ventrolateral saddle, followed by a small V-shaped adventive lobe. In this outline, the suture line is characteristic for a Girtyoceras species.

Discussion. For a comparison with the co-occurring G. luscinia, see under that species. The new species be-
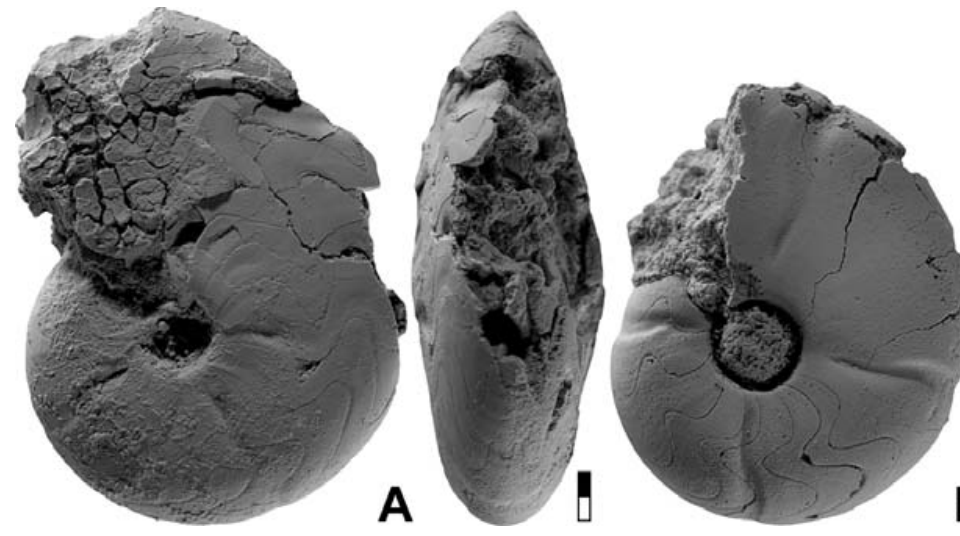

B

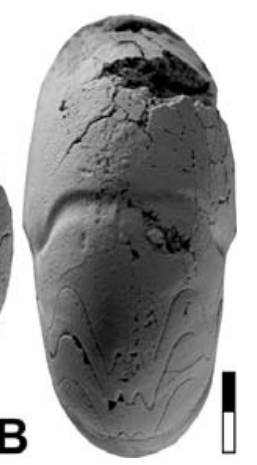

Figure 9. Girtyoceras ibnkhaldouni n. sp. A. Holotype MB.C.13214.1 from locality Chebket el Hamra-F; $\times 2.5$. B. Paratype MB.C.13214.2 from locality Chebket el Hamra-F; $\times 4.0$. 

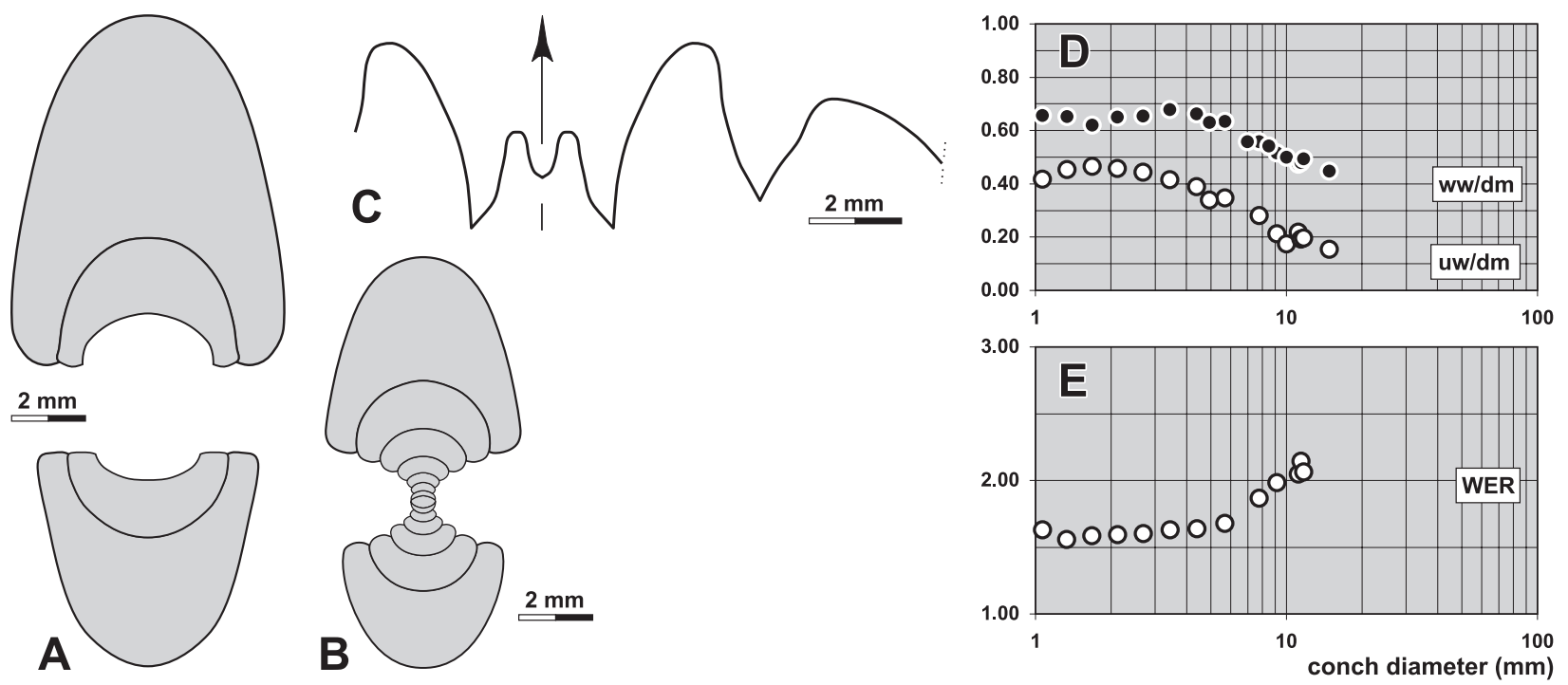

Figure 10. Girtyoceras ibnkhaldouni n. sp. A. Cross section of paratype MB.C.13214.3 from locality Chebket el Hamra-F; $\times 4.0$. B. Cross section of paratype MB.C.13214.4 from locality Chebket el Hamra-F; × 4.0. C. Suture line of holotype MB.C.13214.1 from locality Chebket el Hamra-F, at $14.8 \mathrm{~mm} \mathrm{dm}, 6.0 \mathrm{~mm} \mathrm{ww}, 8.1 \mathrm{~mm}$ wh; $\times 5.0$. D, E. Ontogenetic development of the conch width index (ww/dm), umbilical width index (uw/dm) and whorl expansion rate (WER) of all available specimens.

longs to the narrowly umbilicate species of the genus, and comparable are only G. ibergense (but with an oxyconic stage that starts much later).

\section{Sulcogirtyoceras Ruzhencev, 1960}

Type species. Eumorphoceras burhennei Brüning, 1923.

\section{Sulcogirtyoceras sp.}

Figure 11

Material. Three limonitic steinkern specimens between 5 and $16 \mathrm{~mm}$ conch diameter from horizon $\mathrm{CeH}-2$ at locality Chebket el Hamra-F.

Description. The larger specimen MB.C.13215.1 is a fragment of a specimen with an original diameter of $16 \mathrm{~mm}$; it shows the transformation from the widely umbilicate juvenile stage with faint riblets to the narrowly umbilicate preadult stage with strong constrictions. Less than one third is preserved of the last whorl, which shows a pronounced umbilical rim and concavo-

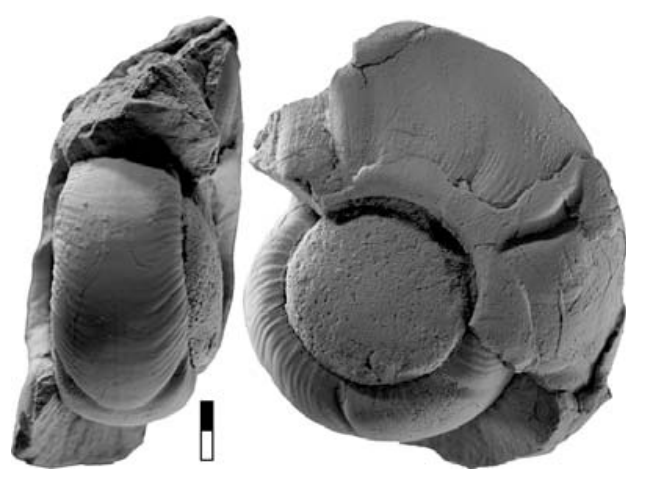

Figure 11. Sulcogirtyoceras sp., specimen MB.C.13215.1 from locality Chebket el Hamra-F; $\times 3.0$. convex constrictions that begin on the inner flanks. They form a shallow lateral sinus, a very high ventrolateral projection, and a shallow ventral sinus. Remains of rather coarse growth lines are visible on the steinkern. The inner whorl, corresponding to a diameter of $8 \mathrm{~mm}$, possesses a ventrally depressed whorl cross section and a wide umbilicus. The flanks bear numerous forwardly directed faint riblets and deep constrictions with the same course; they are deepest on the flanks and almost disappear on the venter, where they form a high projection.

The small specimen MB.C.13215.3 (5 mm dm) represents the early juvenile calyx stage with a very wide umbilicus, a sharp umbilical margin that is occupied by short and sharp riblets, and an almost smooth, flattened venter.

Superfamily Dimorphoceratoidea Hyatt, 1884 Family Dimorphoceratidae Wedekind, 1918

\section{Metadimorphoceras Moore, 1958}

Type species. Goniatites splendidus Brown, 1841.

Discussion. Metadimorphoceras has a near-global distribution with 22 valid species listed in the AMMON database (Korn \& Ilg 2007). Separation of species is almost completely based on suture line characters. Twelve of the species were erected on material from Europe; these derive from a wide stratigraphic interval ranging from the middle Late Viséan Goniatites crenistria interval to the Kinderscoutian R1 Zone in Europe (Moore 1939) and even in the Yeadonian G1 Zone in Arkansas (Manger 1988).

On the basis of their suture lines, the Western and Central European species of Metadimorphoceras can be 
grouped as follows (for a phylogenetic concept of the genus, see Manger 1988):

A - species with simple subdivision of the adventive lobe:

M. pseudodiscrepans (Moore, 1939): with incipient subdivision of the E1 lobe;

M. hodsoni (Moore, 1958): with bifid, narrow E1 lobe;

M. wiswellense (Moore, 1939): with denticulation of the E1 lobe;

M. moorei (Hodson, 1954): with bifid, wide E1 lobe.

B - species with secondary subdivision of the adventive lobe and simple subdivision of the E2 lobe:

M. denticulatum (Schmidt, 1925): with weak secondary subdivision of the adventive lobe and multiple denticulation of the E1 lobe;

M. saleswheelense (Moore, 1939): with weak secondary subdivision of the adventive lobe and bifid E1 lobe;

M. ribblense (Moore, 1936): with weak secondary subdivision of the adventive lobe and simple E1 lobe;

M. splendidum (Brown, 1841): with strong secondary subdivision of the adventive lobe and denticulation of the E1 lobe.

C - species with secondary subdivision of the adventive lobe and secondary subdivision of the E2 lobe:

M. anguinosum $\mathrm{n}$. sp.: with incipient secondary denticulation of the adventive lobe and denticulation of the E1 lobe;

M. inflatum (Moore, 1939): with weak secondary subdivision of the adventive lobe and bifid E1 and E2 lobes;

M. pix Korn, 1997: with strong secondary denticulation of the adventive lobe and weak denticulation of the E1 lobe;

M. complex (Moore, 1939): with strong secondary denticulation of the adventive lobe and clear denticulation of the E1 lobe;

M. varians (Moore, 1939): with strong secondary denticulation of the adventive lobe and strong denticulation of the E1 lobe.

\section{Metadimorphoceras anguinosum n. sp.}

Figures $12-13$

Derivation of name. After Latin anguinosus, -um = like a snake, because of the narrow and subdivided median saddle.

Holotype. Specimen MB.C.13233.1 (Korn \& Ebbighausen 2006 Coll.); illustrated in Figure 12A

Type locality and horizon. Chebket el Hamra-I (Jerada Basin, NEMorocco); horizon $\mathrm{CeH}-2$, probably Neoglyphioceras spirale Zone (middle Brigantian, Early Carboniferous).

Material. 26 limonitic steinkern specimens of phragmocones between 4 and $19 \mathrm{~mm}$ conch diameter from horizon $\mathrm{CeH}-2$ at localities Chebket el Hamra-F, I, and T.

Diagnosis. Metadimorphoceras with thinly pachyconic conch at $5 \mathrm{~mm}$ diameter $(\mathrm{ww} / \mathrm{dm}=0.65-0.70)$ and thickly discoidal conch at 12 $15 \mathrm{~mm}$ diameter $(\mathrm{ww} / \mathrm{dm}=0.50-0.60)$. Umbilicus funnel-shaped and almost closed in all stages. Suture line with tertiary subdivision of the external lobe, of which the dorsal side shows delicate denticulation, and primarily subdivided adventive lobe, of which the dorsal branch shows incipient secondary notching.

Description. The ontogenetic development (Figs 13D, E) is simple with a continuously decreasing ww/dm ratio $(\mathrm{ww} / \mathrm{dm}=0.80$ at $2 \mathrm{~mm} \mathrm{dm} ; 0.45$ at $19 \mathrm{~mm} \mathrm{dm})$ and a continuously increasing apertural height $(\mathrm{WER}=1.80$ at $2 \mathrm{~mm} \mathrm{dm} ; 2.65$ at $19 \mathrm{~mm} \mathrm{dm}$ ). The umbilicus is almost closed in all stages above $1.5 \mathrm{~mm}$ dm.

The sectioned paratype MB.C.13272.1 shows five whorls at a maximum diameter of $12 \mathrm{~mm}$ (Fig. 13A). At this diameter, the conch is thickly discoidal (ww/ $\mathrm{dm}=0.56$ ) with an almost completely closed, funnelshaped umbilicus and a rather high aperture (WER = 2.45). The conch is widest at the rounded umbilical margin, from which the flanks converge towards the narrowly rounded venter. Early whorls have, at $3 \mathrm{~mm} \mathrm{dm}$, continuously rounded flanks and venter as well as a very narrow umbilicus (uw $/ \mathrm{dm}=0.06$ ).

The suture line of the largest specimen, holotype MB.C.13233.1 (approximately $17 \mathrm{~mm}$ conch diameter) demonstrates that $M$. anguinosum belongs to the more advanced species of the genus (Fig. 13C). It has a strikingly subdivided external lobe, in which a very narrow, high median saddle is raised. Both secondary lobes of the external lobe are further denticulate, with the ven-
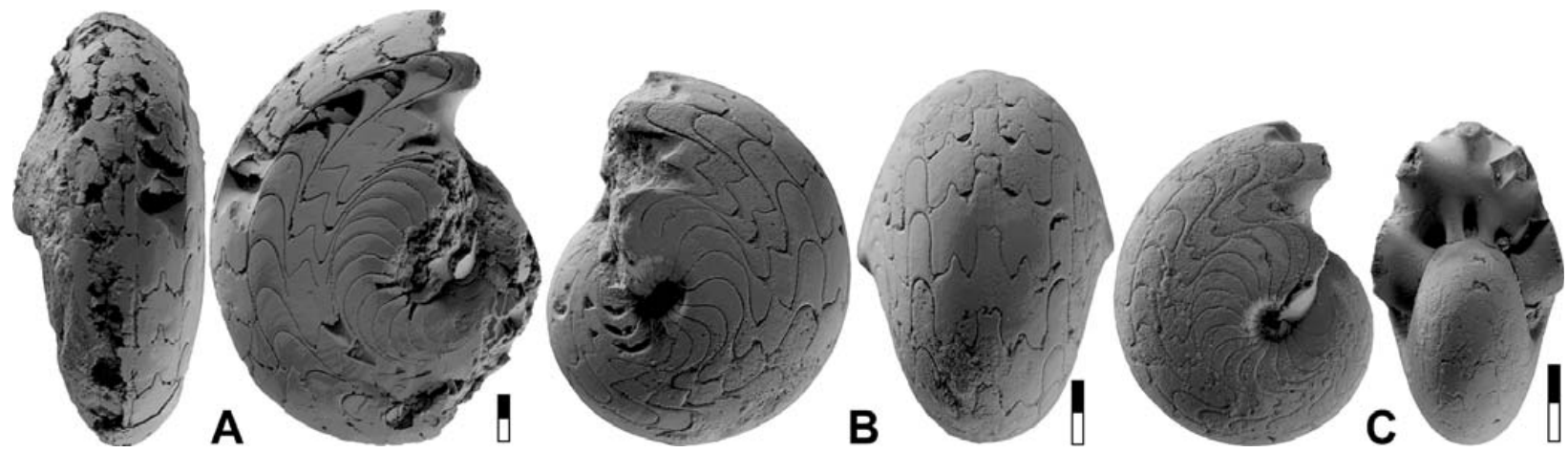

Figure 12. Metadimorphoceras anguinosum n. sp. A. Holotype MB.C.13233.1 from locality Chebket el Hamra-I; $\times 2.5$. B. Paratype MB.C.13216.1 from locality Chebket el Hamra-F; × 3.5. C. Paratype MB.C.13216.2 from locality Chebket el Hamra-F; $\times 4.0$. 

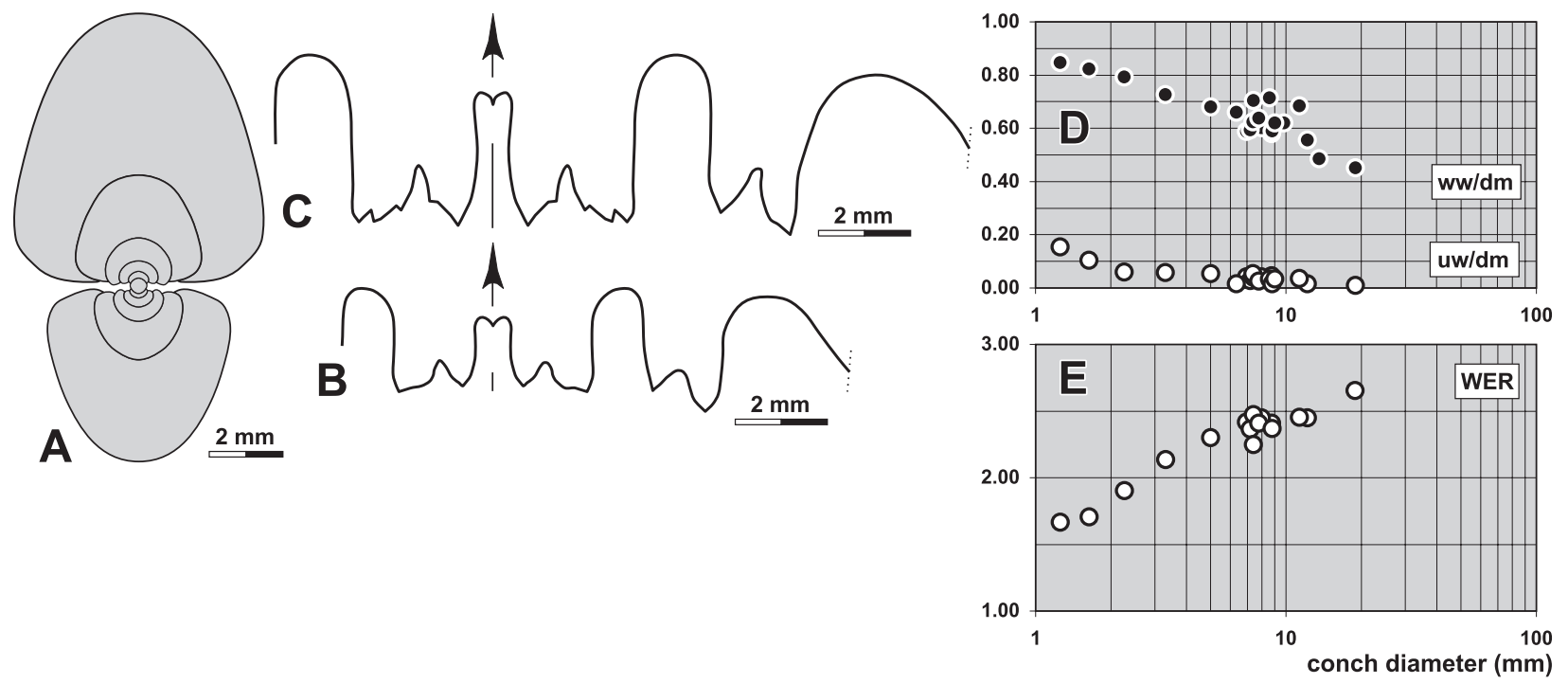

Figure 13. Metadimorphoceras anguinosum n. sp. A. Cross section of paratype MB.C.13272.1 from locality Chebket el Hamra-T; $\times$ 4.0. B. Suture line of paratype MB.C.13216.1 from locality Chebket el Hamra-F, at $10.8 \mathrm{~mm} \mathrm{dm}, 7.2 \mathrm{~mm} w w, 6.0 \mathrm{~mm}$ wh; $\times 5.0$. C. suture line of holotype MB.C.13233.1 from locality Chebket el Hamra-I, at $9.7 \mathrm{~mm}$ wh; $\times 5.0$. D, E. Ontogenetic development of the conch width index (ww/dm), umbilical width index (uw/dm) and whorl expansion rate (WER) of all available specimens.

tral side (E2) possessing a large dorsal prong and a very small ventral notch. The dorsal side (E1), which is separated from the E2 lobe by a narrow and acute saddle, is subdivided into three small notches. Behind the narrow, tongue-shaped ventrolateral saddle follows the bifid adventive lobe, of which the dorsal prong shows the indication of further subdivision.

A less advanced suture line can be studied in the smaller paratype MB.C.13216.1 (11 mm dm), in which the subdivision of the lobes is less striking (Fig. 13B). The external lobe shows only secondary subdivision, resulting in unequal E1 and E2 lobes, of which the E1 lobe is the deeper and wider element. The adventive lobe shows only primary subdivision with two prongs.

Discussion. Most species of Metadimorphoceras with a similarly advanced sutural subdivision are stratigraphically younger. M. anguinosum has, in the suture line, some resemblance to $M$. denticulatum, which has a similar pattern of sutural subdivision. Both are also similar in conch morphology, but in M. anguinosum, the E2 lobe has an incipient further subdivision.
M. hodsoni from the slightly younger horizon at Chebket el Hamra has a less advanced suture line, with a bifid adventive lobe, a bifid E1 lobe, and a simple E2 lobe.

\section{Metadimorphoceras hodsoni Moore, 1958}

Figures 14-15

1958 Dimorphoceras (Metadimorphoceras) hodsoni Moore, p. 223, pl. 14, figs 1,2 .

1988 Metadimorphoceras hodsoni. - Manger, textfig. 2B.

Holotype. Specimen GSM ZI4020 (Moore Coll.); figured by Moore (1958, pl. 14, fig. 2).

Type locality and horizon. Townland of Carraun, two miles southsouthwest of Kiltyclogher (Co. Leitrim, Ireland); P1c Subzone, associated with Neoglyphioceras spirale (Late Viséan).

Material. 16 limonitic steinkern specimens of phragmocones with conch diameters ranging from 7 and $13 \mathrm{~mm}$, from horizon $\mathrm{CeH}-4$ at localities Chebket el Hamra-A, B, C, and S.

Diagnosis. Metadimorphoceras with thinly pachyconic conch at $5 \mathrm{~mm}$ diameter $(\mathrm{ww} / \mathrm{dm}=0.65-0.70)$ and thickly discoidal conch at $12-$ $15 \mathrm{~mm}$ diameter $(\mathrm{ww} / \mathrm{dm}=0.50-0.60)$. Umbilicus funnel-shaped and almost closed in all stages. Suture line with secondarily subdivided
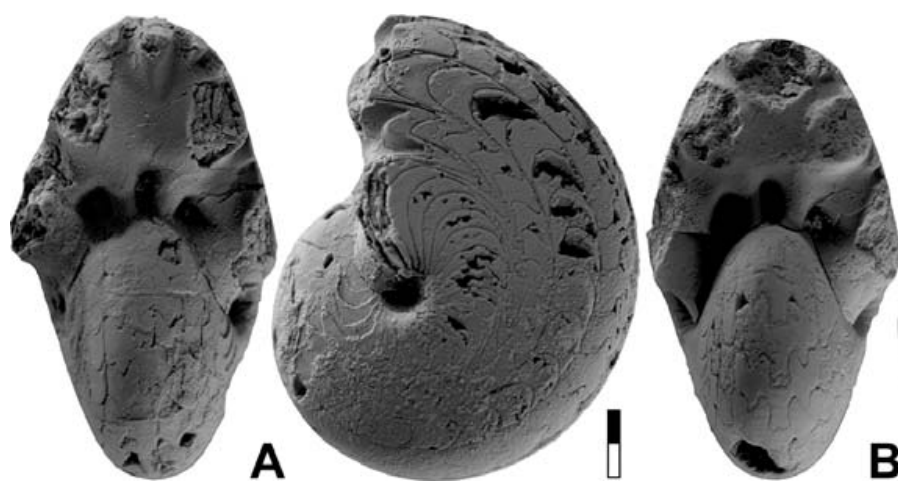

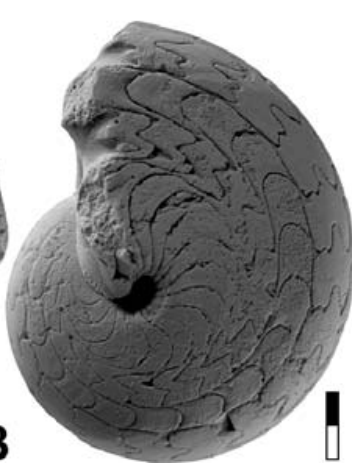

Figure 14. Metadimorphoceras hodsoni Moore, 1958. A. Specimen MB.C.13201.1 from locality Chebket el Hamra-A; $\times 3.5$. B. Specimen MB.C.13270.1 from locality Chebket el Hamra-S; $\times 3.5$. 


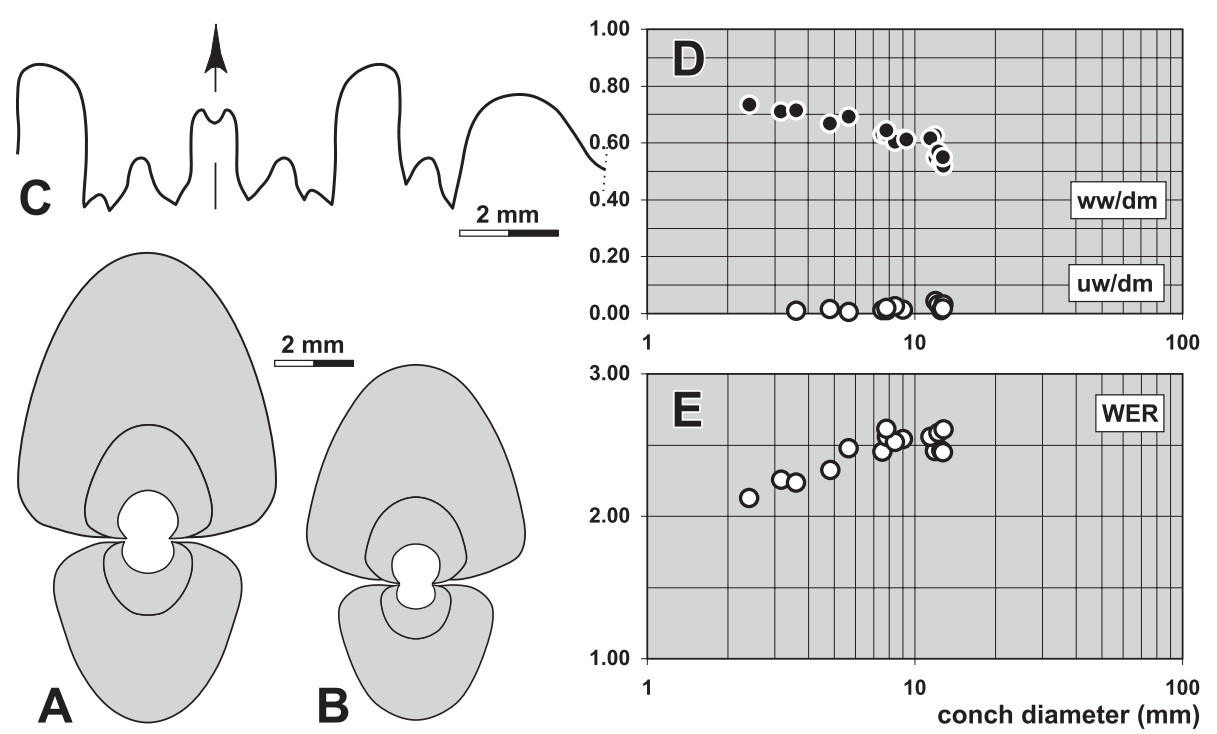

Figure 15. Metadimorphoceras hodsoni Moore, 1958. A. Cross section of specimen MB.C.13270.2 from locality Chebket el Hamra-S; $\times 4.0$. B. Cross section of specimen MB.C.13270.3 from locality Chebket el Hamra-S; $\times 4.0$. C. Suture line of specimen MB.C.13270.1 from locality Chebket el Hamra-S, at $12.0 \mathrm{~mm} \mathrm{dm}, 6.9 \mathrm{~mm}$ ww, $7.5 \mathrm{~mm} \mathrm{wh} \times 5.0$. D, E. Ontogenetic development of the conch width index (ww/dm), umbilical width index (uw/dm) and whorl expansion rate (WER) of all available specimens.

external lobe, of which the dorsal side shows tertiary denticulation, and primarily subdivided adventive lobe.

Description. Ontogenetic changes of the conch can be seen in the ww/dm ratio and also in the whorl expansion rate (Figs 15D, E). As characteristic for dimorphoceratids, the ww/dm ratio decreases continuously and the whorl expansion rate is heightened. Intraspecific variability is low within the investigated material.

The two sectioned specimens MB.C.13270.2 and MB.C.13270.3 do not show the inner whorls, but provide insight into the conch development between 2.5 and $12 \mathrm{~mm}$ diameter (Figs 15A, B). The general form is similar in these stages, with the exception of the ww/ $\mathrm{dm}$ ratio that decreases from 0.74 at $2.4 \mathrm{~mm} \mathrm{dm}$ to 0.55 at $12 \mathrm{~mm} \mathrm{dm}$. The umbilical margin becomes pronounced at $4 \mathrm{~mm}$ conch diameter, and separates the converging flanks from the almost closed, funnelshaped umbilicus. The aperture becomes rapidly higher during ontogeny, leading to a whorl expansion rate of almost 2.50 at $12 \mathrm{~mm} \mathrm{dm}$.

Specimen MB.C.13270.1 is well preserved and fully chambered at $12.5 \mathrm{~mm}$ diameter (Fig. 14B). In terms of conch ratios, it closely resembles cross section MB.C.13270.2, and also shows the funnel-shaped umbilicus, the strongly conversing flanks, and the narrowly rounded venter.

The suture line of specimen MB.C.13270.1 (drawn at $12 \mathrm{~mm} \mathrm{dm}$ ) shows an insignificant amount of asymmetry in the serration of the external lobe (Fig. 15C). Secondary and tertiary subdivision of the external lobe leads to a V-shaped to lanceolate and acute E2 prong and a bifid E1 prong, both with the same width. The adventive lobe is bifid with a deeper dorsal notch.

Discussion. The material closely resembles, in conch shape and degree of suture line subdivision, the Irish specimens. The faint keel of the type material from Carraun, however is not visible in the steinkern specimens from Chebket el Hamra.

M. hodsoni belongs to the less advanced species of the genus. The other species from Chebket el Hamra, $M$. anguinosum for instance, has a much more advanced suture line, although it is stratigraphically older.

Superfamily Goniatitoidea Hyatt, 1884

Family Goniatitidae de Haan, 1825

Included subfamilies.

Goniatitinae de Haan, 1825 - with narrowly umbilicate inner whorls, a narrow external lobe, and usually acute ventrolateral saddle,

Arnsbergitinae n. subfam. - with widely umbilicate inner whorls, a moderately wide external lobe, and usually subacute or rounded ventrolateral saddle,

Sygambritinae Korn, 1988 - with a narrow external lobe, and tectiform ventrolateral saddle,

Sudeticeratinae Korn \& Ebbighausen, 2006 in Klug et al. 2006 with moderately umbilicate inner whorls, a wide external lobe, a concave median saddle, and a rounded ventrolateral saddle.

Subfamily Goniatitinae de Haan, 1825

Included genera.

Progoniatites Korn, Bockwinkel, Ebbighausen \& Klug, 2003.

Goniatites de Haan, 1825.

Hypergoniatites Ruzhencev \& Bogoslovskaya, 1970.

Goniatitella Korn, 1988.

\section{Goniatites de Haan, 1825}

Type species. Conchiliolithus Nautilites (sphaericus) Martin, 1809 [nomen nudum], = Ammonites sphaericus Sowerby, 1814 (Opinion 420 ICZN, 1956). 
Discussion. Goniatites is a broad genus encompassing 30 species, of which 12 were erected on North Variscan material, listed in the AMMON database (Korn \& Ilg 2007). Many of the species are only briefly described, and some are based on poorly preserved material.

The well-known North-western and Central European species of Goniatites can be grouped as follows:

A - species with spiral ornament:

G. globostriatus (Schmidt, 1925): type material crushed, with coarse falcate ornament in the adult stage;

G. moorei Weyer, 1972: without falcate ornament in the adult stage;

G. spirifer Roemer, 1850: with weak falcate ornament in the adult stage;

G. wedberensis Bisat, 1934: an insufficiently described species, possibly a junior synonym of G. spirifer Roemer, 1850.

B - species without spiral ornament:

G. hudsoni Bisat, 1934: with highly variable, thickly pachyconic to globular conch $(\mathrm{ww} / \mathrm{dm}=0.75-$ 0.95 between 20 and $40 \mathrm{~mm} \mathrm{dm}$ ), distinct dorsolateral projection of the growth lines, a very narrow external lobe, and a low median saddle;

G. crenistria Phillips, 1836: with thinly to thickly pachyconic conch $(\mathrm{ww} / \mathrm{dm}=0.70-0.80$ at 20 and $0.60-0.70$ at $40 \mathrm{~mm} \mathrm{dm}$ ), low dorsolateral projection of the growth lines, a moderate external lobe, and a moderate median saddle;

G. sphaericus (Sowerby, 1814): only known from the holotype, possibly senior synonym of G. fimbriatus, but with lower median saddle;

G. fimbriatus (Foord \& Crick, 1897): with variable, thickly pachyconic to globular conch (ww/ $\mathrm{dm}=0.70-0.90$ between 20 and $40 \mathrm{~mm} \mathrm{dm}$ ), moderate dorsolateral projection of the growth lines, a moderate external lobe, and a moderate median saddle;

G. fuhrmanni Schindewolf, 1951: a problematic species, horizon not precisely known;

G. involutus de Koninck, 1880: a problematic species;

G. interruptus de Koninck, 1844: a problematic species;

G. antiquatus Bisat, 1934: an insufficiently described species, possibly a synonym of G. hudsoni Bisat, 1934.

\section{Goniatites crenistria Phillips, 1836}

Figures 16-21

1836 Goniatites crenistria Phillips, p. 234, pl. 19, figs 7-9.

1925 Glyphioceras crenistria. - Schmidt, p. 565, pl. 21, figs 1-3, pl. 23, figs $13-14$

1925 Glyphioceras crenistria var. globoides Schmidt, p. 566, pl. 21, fig. 1.

1928 Goniatites crenistria dinckleyense Bisat, p. 132, pl. 6A, fig. 1.

1963 Goniatites crenistria. - Nicolaus, p. 96, pl. 1, figs 1, 3.
1988 Goniatites crenistria. - Korn, p. 83, pl. 17, figs 1, 4, pl. 18, figs $1-11$.

Holotype. Specimen NHM c282 (Gilbertson Coll.); figured by Phillips (1836, pl. 19, figs 7-9), refigured here in Figure 16.

Type locality and horizon. 'Bolland' (West Yorkshire); 'Mountain Limestone' (Late Viséan).

Material. 76 specimens from horizon $\mathrm{CeH}-1$ of the locality Chebket el Hamra-N; they range in their size from 25 and $120 \mathrm{~mm}$ diameter. All are preserved as sideritic nodules in which usually only the body chamber is preserved. Inner whorls, if present at all, are preserved only as fragments.

Diagnosis. Goniatites with globular conch at $10 \mathrm{~mm}$ diameter (ww/ $\mathrm{dm}=0.90-1.00$ ), pachyconic conch at $30 \mathrm{~mm}$ diameter (ww/ $\mathrm{dm}=0.65-0.75)$, and thickly discoidal to thinly pachyconic conch at $50 \mathrm{~mm}$ diameter $(\mathrm{ww} / \mathrm{dm}=0.55-0.65)$. Umbilicus very narrow in all stages larger than $10 \mathrm{~mm} \mathrm{dm}(\mathrm{uw} / \mathrm{dm}=0.05-0.10)$, in the adult stage slightly opening; umbilical wall rounded. Ornamentation with crenulated biconvex and rectiradiate growth-lines with low dorsolateral projection and higher ventrolateral projection; external sinus deep. No spiral lines. Suture line with V-shaped, moderately narrow external lobe $(0.50$ of the external lobe depth, $0.90-1.00$ of the adventive lobe), and moderate median saddle ( 0.40 of the external lobe depth); E lobe Y-shaped in very large stages. Flanks of the external lobe almost straight, ventrolateral saddle acute, adventive lobe V-shaped with almost straight flanks.

Description. Growth stages between 18 and $120 \mathrm{~mm}$ are represented in the material from Chebket el Hamra, and cross sections of material from the Rhenish Mountains and Harz are shown for comparison. Intraspecific variability within the material from Chebket el Hamra is very low, all specimens plot within a very narrow range (Figs 18D, E). The ww/dm ratio decreases almost continuously within the observable growth interval, being $0.70-0.80$ at $20 \mathrm{~mm}, 0.60-0.70$ at $50 \mathrm{~mm} \mathrm{dm}$, and approximately 0.50 at $90 \mathrm{~mm} \mathrm{dm}$. At the same time, the umbilicus opens slightly from a uw/dm ratio of 0.10 at $20 \mathrm{~mm} \mathrm{dm}$ to 0.15 at $90 \mathrm{~mm} \mathrm{dm}$. The aperture becomes significantly higher during this interval, with a WER that increases from 1.50 at $30 \mathrm{~mm} \mathrm{dm}$ to almost 2.00 at $90 \mathrm{~mm} \mathrm{dm}$.

The two sectioned specimens from Germany (Figs 19-20) closely fit the conch geometry of the Moroccan material. Differences can only be seen in the whorl expansion rate, which is somewhat higher in the

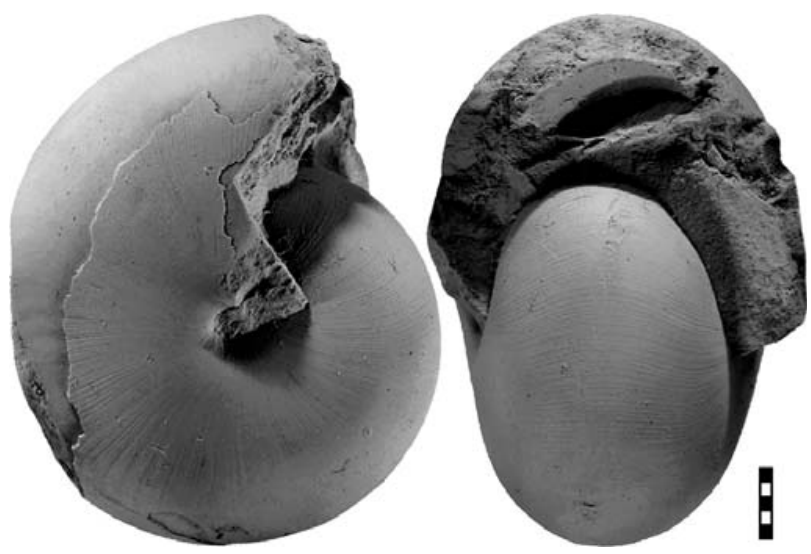

Figure 16. Goniatites crenistria Phillips, 1836, holotype NHM c282 from 'Bolland', West Yorkshire (Gilbertson Coll.); $\times 1.50$. 

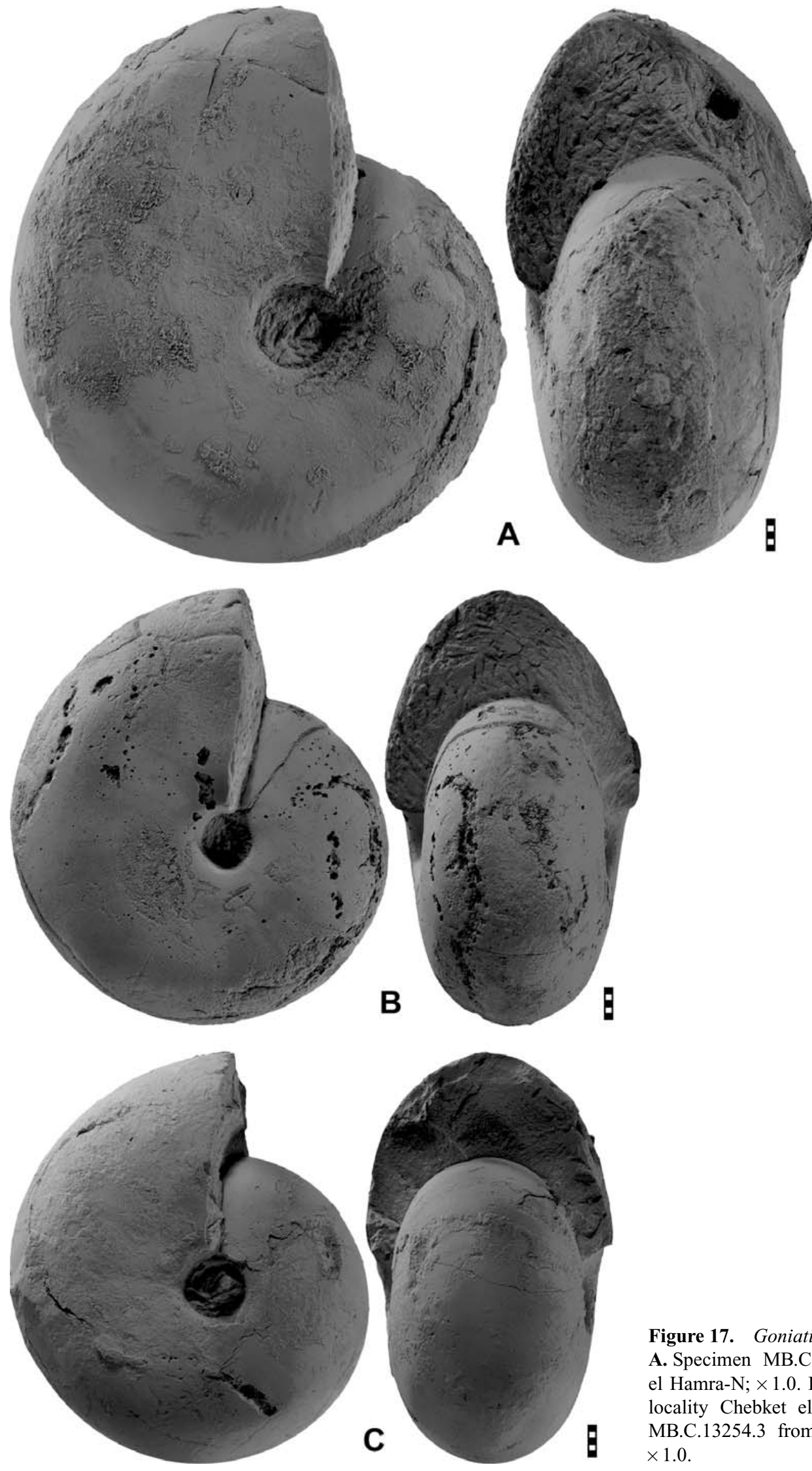

Figure 17. Goniatites crenistria Phillips, 1836 A. Specimen MB.C.13254.1 from locality Chebket el Hamra-N; × 1.0. B. Specimen MB.C.13254.2 from locality Chebket el Hamra-N; $\times 1.0$. C. Specimen MB.C.13254.3 from locality Chebket el Hamra-N; $\times 1.0$.

German specimens. However, these two specimens show differences in this character, with the specimen from the Harz possessing a much higher aperture in intermediate growth stages.
Specimen MB.C.13256.3 is the largest available specimen; it is, with $120 \mathrm{~mm}$ conch diameter, possibly the largest known individual of the genus Goniatites. The body chamber is slightly crushed, but it can be seen 

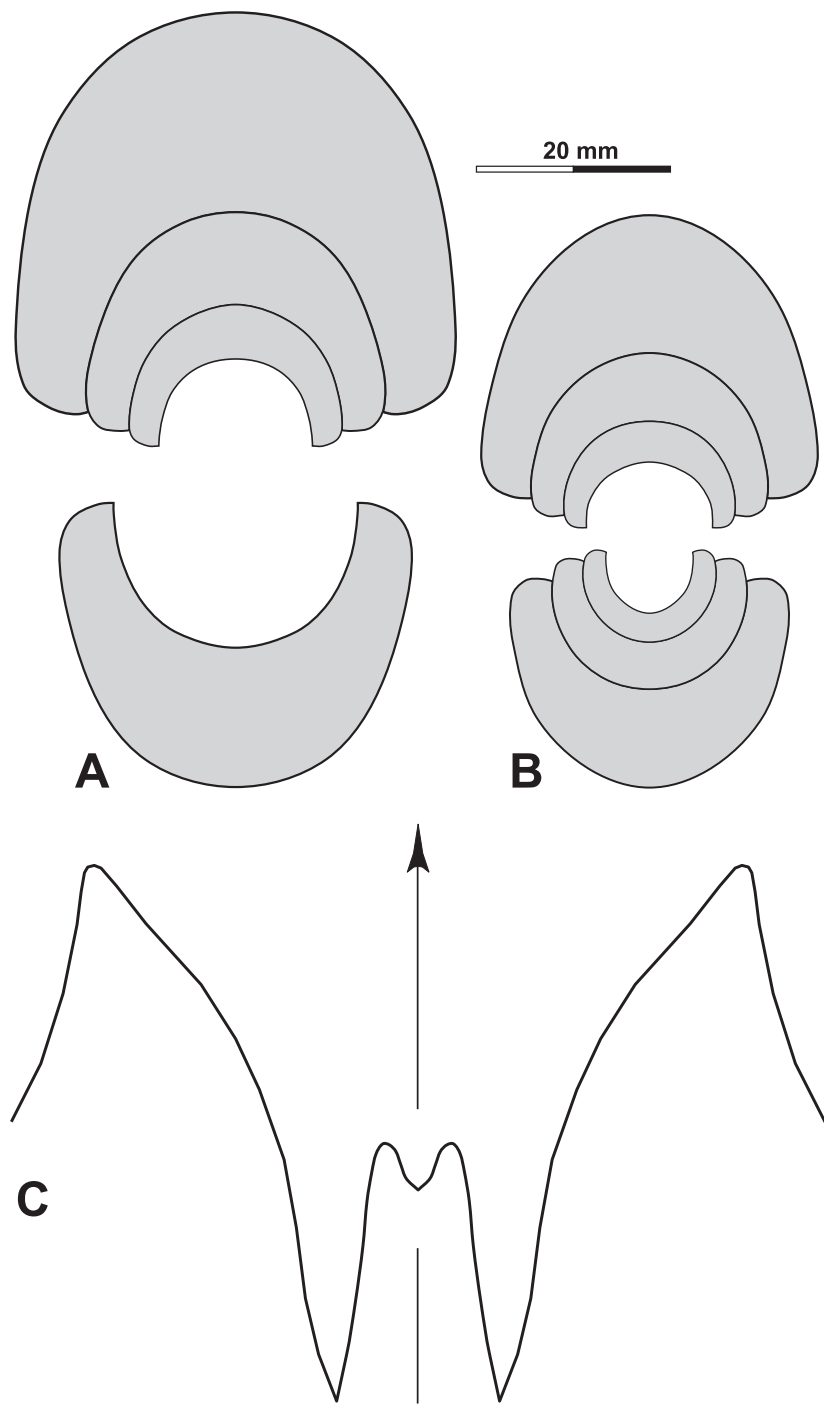

B
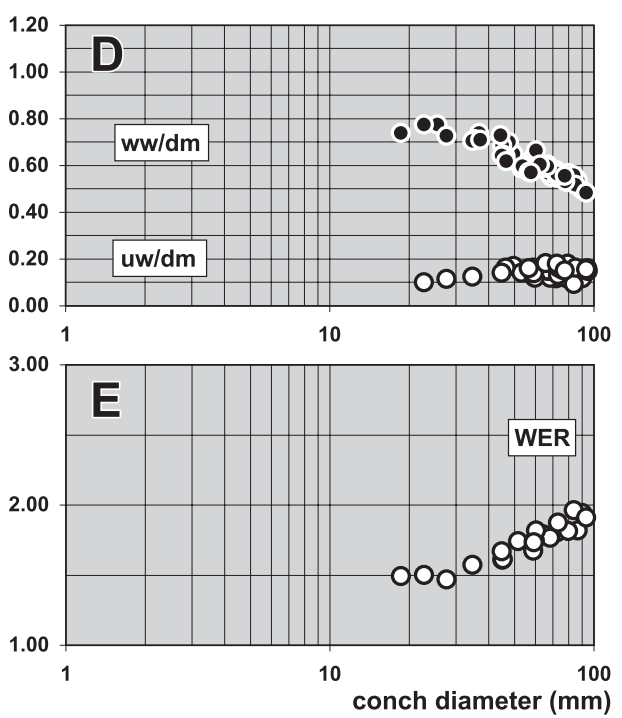

Figure 18. Goniatites crenistria Phillips, 1836. A. Cross section of specimen MB.C.13254.4 from locality Chebket el Hamra-N; $\times$ 1.0. B. Cross section of specimen MB.C.13256.1 from locality Chebket el Hamra-N; $\times 1.0$. C. Suture line of specimen MB.C.13256.2 from locality Chebket el Hamra-N, at $38 \mathrm{~mm}$ ww, $26 \mathrm{~mm}$ wh; $\times 3.5$. D, E. Ontogenetic development of the conch width index $(\mathrm{ww} / \mathrm{dm})$, umbilical width index (uw/dm) and whorl expansion rate (WER) of all available specimens.
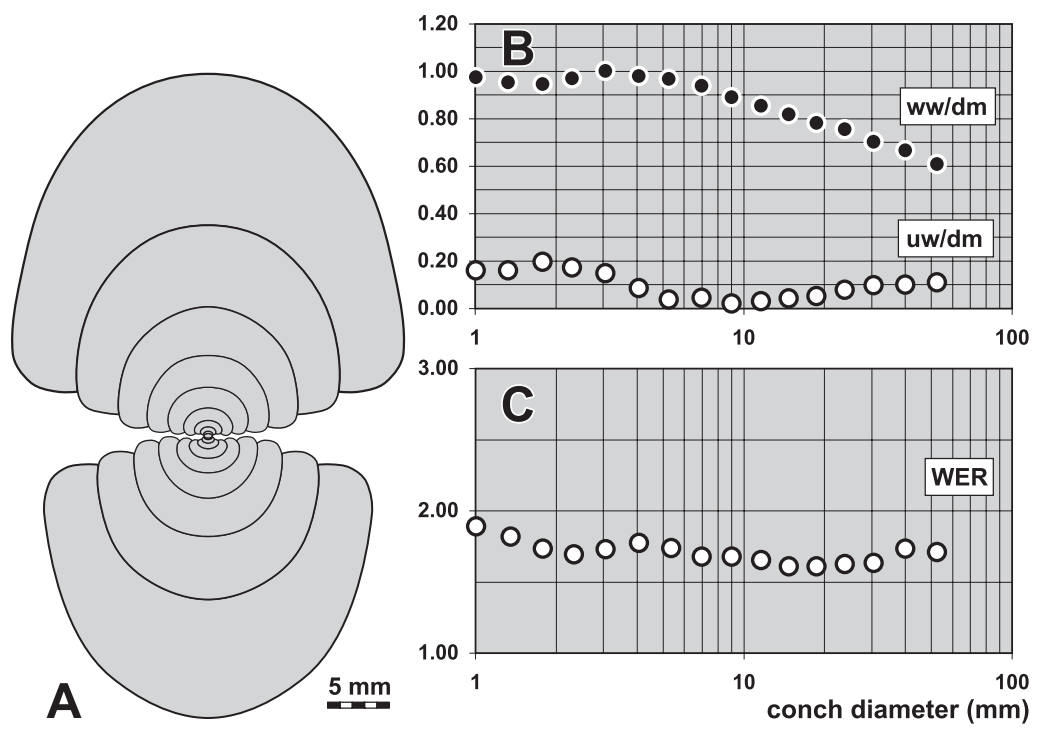

Figure 19. Goniatites crenistria Phillips, 1836 from Oese, Rhenish Mountains (Paproth Coll.). A. Cross section of specimen MB.C.13297; $\times 1.25$. B, C. Ontogenetic development of the conch width index (ww/ $\mathrm{dm})$, umbilical width index (uw/dm) and whorl expansion rate (WER) of specimen MB.C.13297. 

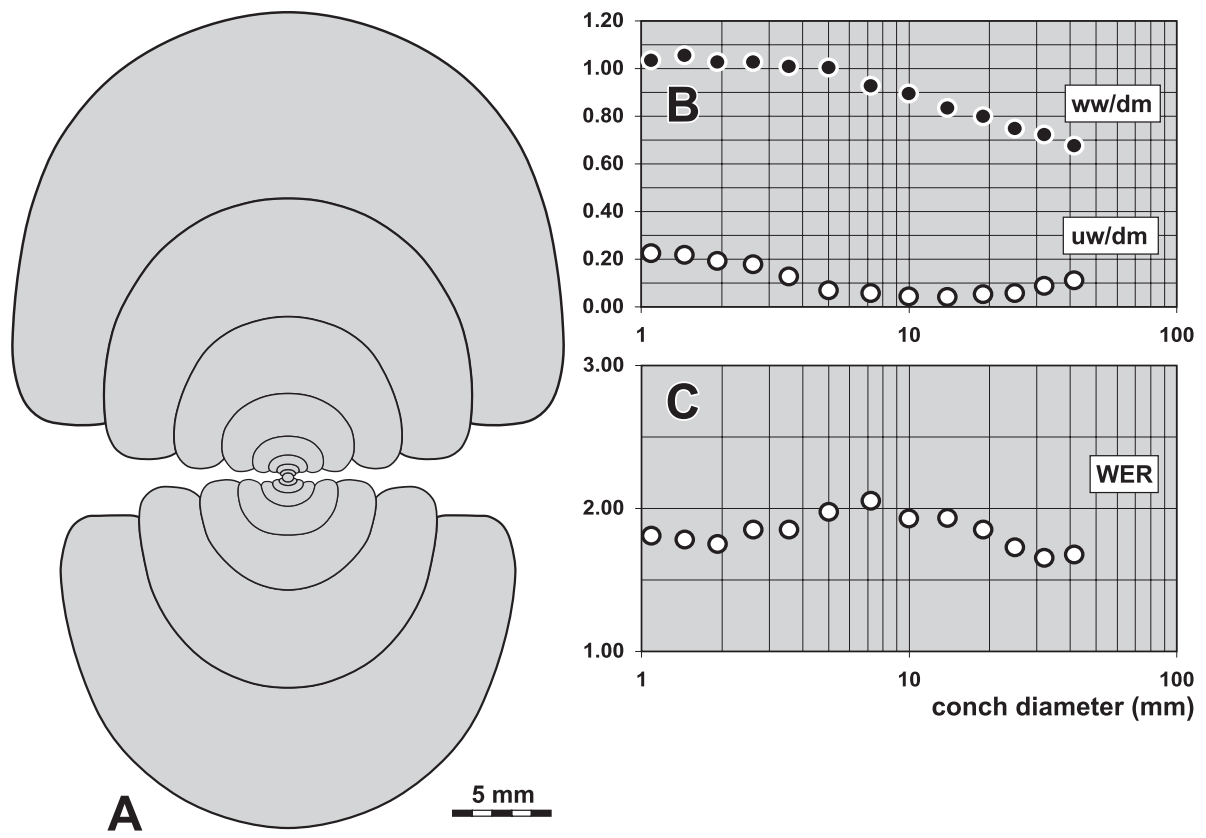

that the conch is discoidal in this stage (ww/ $\mathrm{dm}=0.48)$ with a narrow umbilicus $(\mathrm{uw} / \mathrm{dm}=0.16)$. It is probably fully mature, possessing a well-visible pairwise thickening of the internal shell in front of the last septum.

MB.C.13254.1 is also one of the larger, nearly complete specimens (Fig. 17A). It has a diameter of $86 \mathrm{~mm}$ and is thickly discoidal $(\mathrm{ww} / \mathrm{dm}=0.54)$ with a very narrow umbilicus (uw $/ \mathrm{dm}=0.15$ ) and a low aperture $(\mathrm{WER}=1.82)$. It is a smooth steinkern specimen that possesses, in the dorsal region, shell remains with crenulated growth lines these extend in a rectiradiate direction and with biconvex course across flanks and venter. The lateral sinus of these is very shallow, the ventrolateral projection is low, and the ventral sinus is very deep.

The two smaller specimens MB.C.13254.2 and MB.C.13254.3 (68 and $64 \mathrm{~mm}$ in $\mathrm{dm}$ ) are similar in their preservation with a smooth steinkern and well- preserved shell remains in the dorsal area (Figs 17B, C). They differ in the course of the growth lines, being slightly biconvex with shallow lateral sinus in MB.C.13254.3 though the lateral sinus is lacking in specimen MB.C.13254.2.

The material from Chebket el Hamra permits study of the suture line in a very large individual (Fig. 18C). Specimen MB.C.13256.2 (38 mm whorl width, corresponding to a conch diameter of about $64 \mathrm{~mm}$ ) shows a Yshaped external lobe with incurved flanks, a moderate median saddle ( 0.48 of the E lobe depth), an acute and asymmetric ventrolateral saddle, and a V-shaped, dorsally inclined adventive lobe. The external lobe is moderately narrow, being less wide than the adventive lobe, measured at half depth. Its width/depth ratio is only 0.54 .

Discussion. Goniatites crenistria can easily be separated from other crenistriate species of Goniatites. The
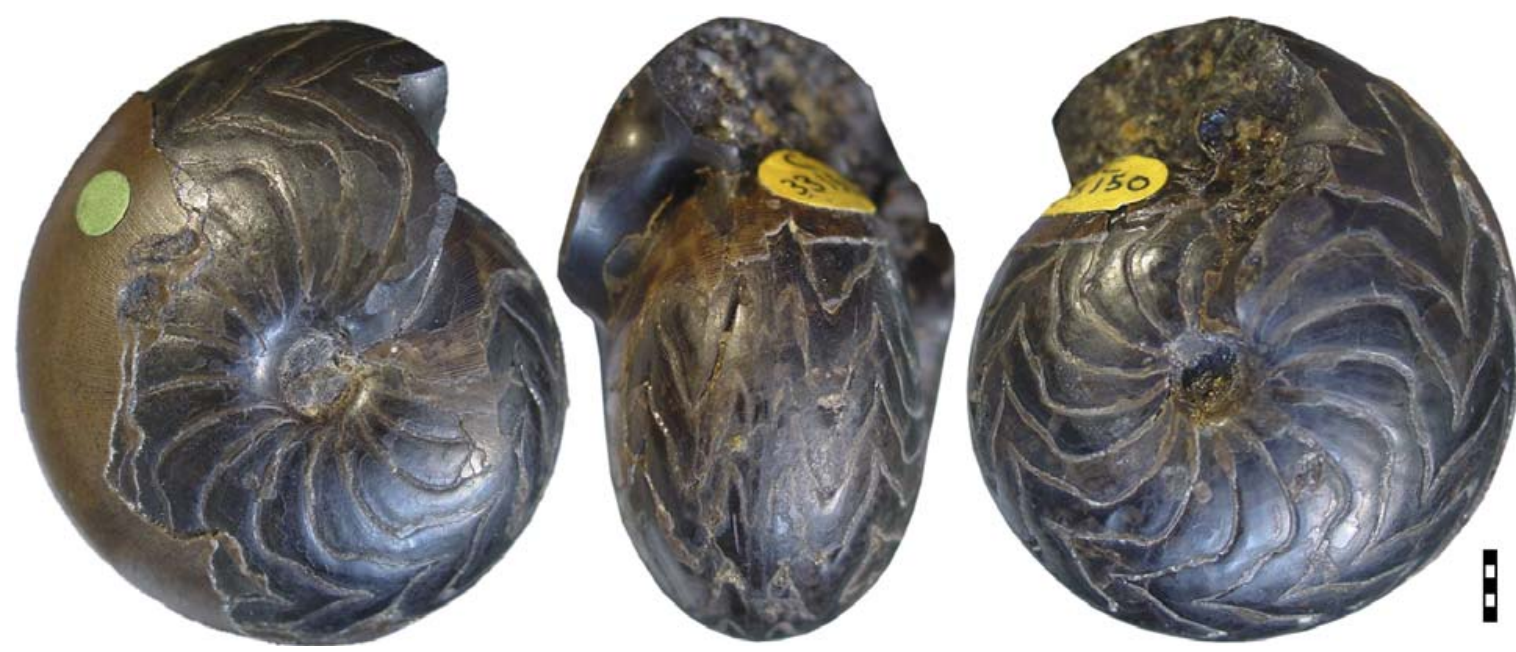

Figure 21. Goniatites crenistria Phillips, 1836 (holotype of 'Goniatites crenistria dinckleyense Bisat, 1928'), specimen NHM c33150 from Dinckley, Lancashire (Moore Coll.); $\times 1.50$. This figure is available in colour online at museum-fossilrecord.wiley-vch.de 


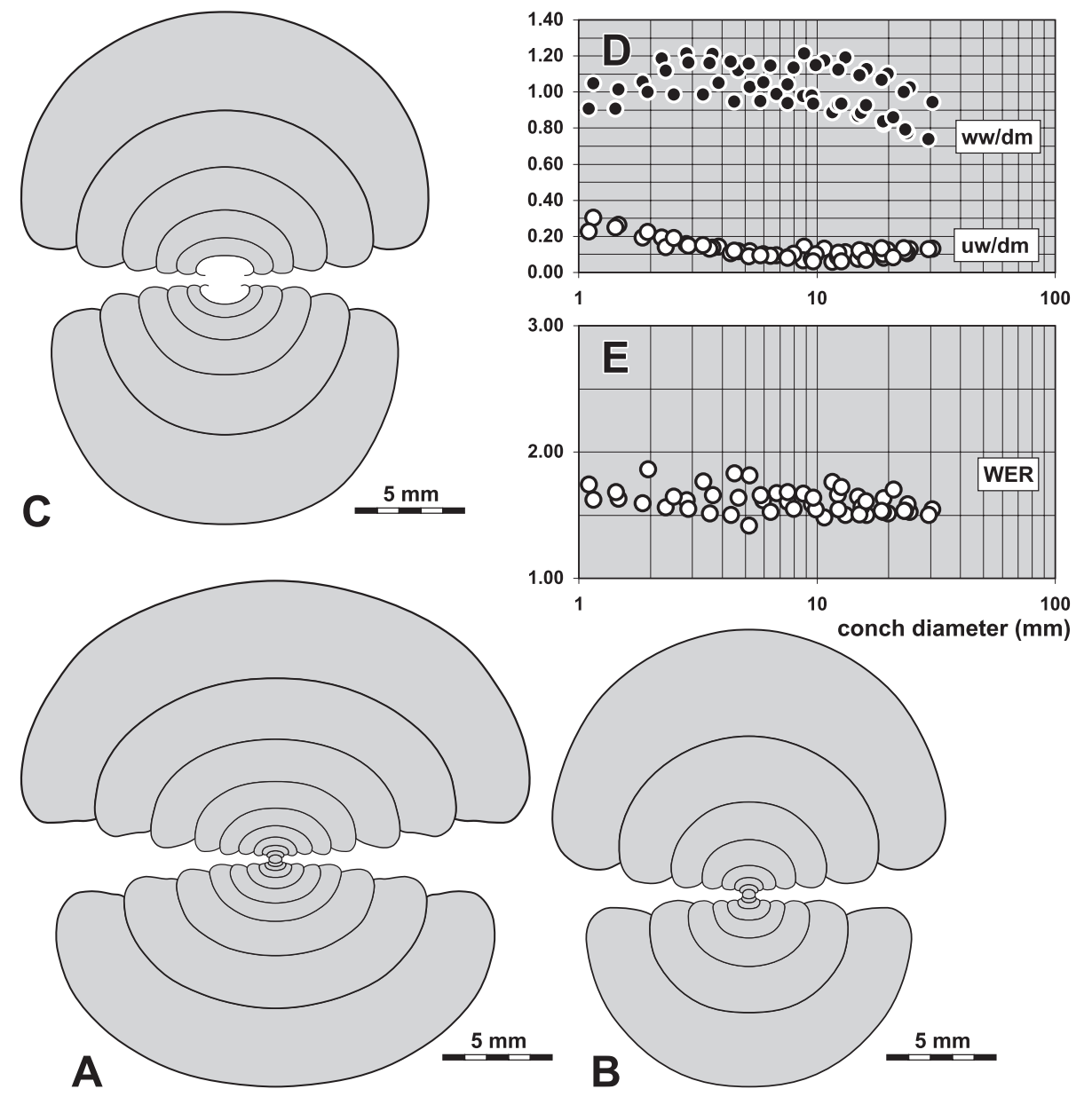

Figure 22. Goniatites hudsoni Bisat, 1934 from bed 100 of the Praia de Murração section (Korn \& Horn 1995 Coll.). A. Cross section of specimen MB.C.13310.1; $\times 2.5$ (cuboid variant). B. Cross section of specimen MB.C.13310.2 (non-cuboid variant with high aperture); $\times 2.5$. C. Cross section of specimen MB.C.13310.3 (non-cuboid variant with low aperture); $\times 2.5$. D, E. Ontogenetic development of the conch width index (ww/dm), umbilical width index (uw/dm) and whorl expansion rate (WER) of the four sectioned specimens MB.C.13310.1-MB.C.13310.4.

stratigraphically slightly older species G. hudsoni Bisat, 1934 (Fig. 22) has a distinct dorsolateral projection of the growth lines; G. americanus Gordon, 1971 from the Chainman Shale of Utah has a pronounced dorsolateral projection of the growth lines and also spiral lines around the umbilicus. The African species G. lazarus Korn, Klug \& Mapes, 2005 has an almost closed umbilicus in the adult stage and a narrowly rounded ventrolateral saddle, and G. rodioni Korn \& Ebbighausen, 2006 is globular in the adult stage and possesses a very narrow external lobe.

Goniatites fimbriatus (Foord \& Crick, 1897) is a variable species (Fig. 23), of which the more slender representatives are similar to G. crenistria. G. fimbriatus has a less pronounced ventrolateral projection of the growth lines, a wider external lobe, a wider umbilicus, and spindle-shaped juvenile conchs.

Remarks. Goniatites crenistria is a very common species at many places in central Europe, being the most celebrated index fossil because of its mass occurrence in the Crenistria Limestone of the Rhenish Mountains and Harz (Nicolaus 1963; Korn 1988; Mestermann
1998). It is also abundant at places in North England (Bisat 1924; Moore 1936), but has not been discovered in the fossiliferous sections of Ireland (Brandon \& Hodson 1985). Occurrences in the South Portuguese Zone are quite rare (Korn 1997). Reports from North America are doubtful. They may mostly belong to G. americanus Gordon, 1971.

\section{Goniatites globostriatus (Schmidt, 1925)}

Figures 24-25

1851 Goniatites crenistria. - Sandberger \& Sandberger, p. 74, pl. 5, figs $1 \mathrm{~b}, \mathrm{c}$.

1925 Glyphioceras crenistria var. globostriata Schmidt, p. 566, pl. 23, fig. 13.

1963 Goniatites striatus spirifer. - Nicolaus, p. 107, pl. 4, figs 8-9, pl. 5, figs $8-10$.

1988 Goniatites (?) globostriatus. - Korn, p. 94, pl. 19, figs 2-5, pl. 59, figs $1-4$.

1990a Goniatites (?) globostriatus. - Korn, p. 34, pl. 10, figs 6-9.

1997 Goniatites (?) globostriatus. - Korn, p. 50, pl. 4, fig. 9.

Holotype. Specimen GÖT 480-47 (H. Schmidt Coll.); figured by Schmidt (1925, pl. 23, fig. 13) and Korn (1988, pl. 19, figs 1-2). 


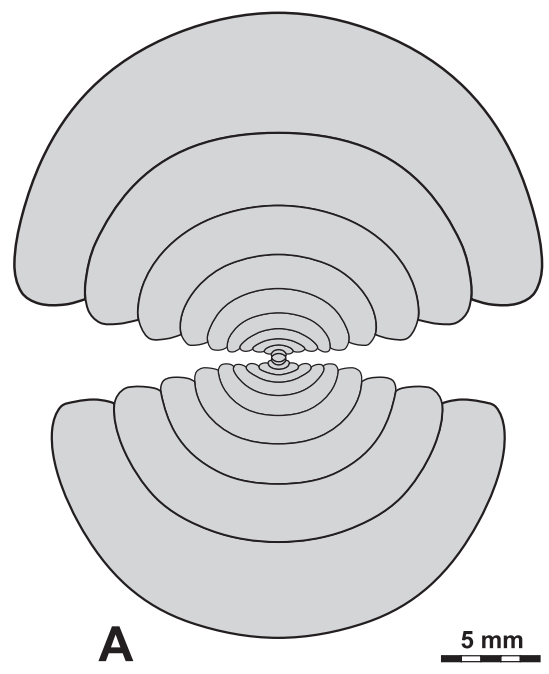

$5 \mathrm{~mm}$
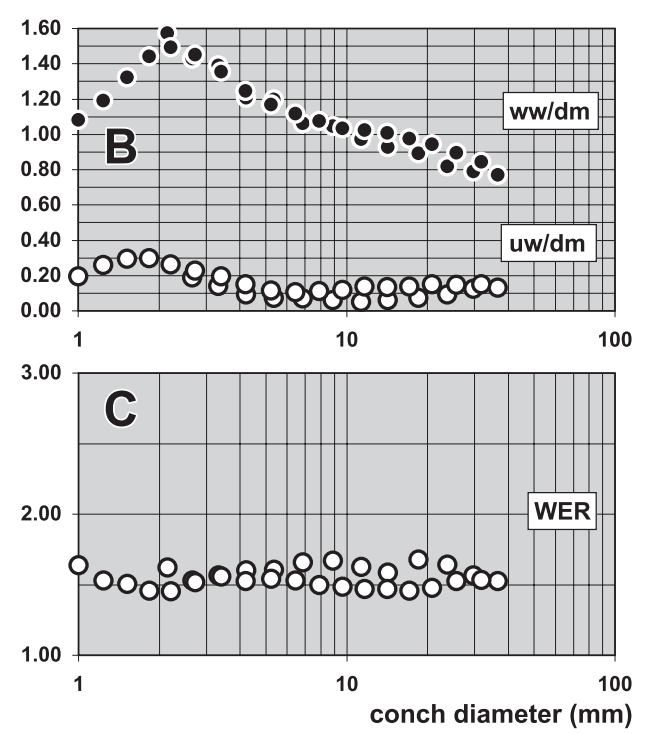

Figure 23. Goniatites fimbriatus (Foord \& Crick, 1897) from Nehden, Rhenish Mountains (Korn 1986 Coll.). A. Cross section of specimen MB.C.13299; $\times 2.0$. B, C. Ontogenetic development of the conch width index (ww/dm), umbilical width index (uw/dm) and whorl expansion rate (WER) of the two sectioned specimens MB.C.13299.1 and MB.C.13299.2.
Type locality and horizon. Oese near Menden (Rhenish Mountains); 'crenistria Zone' (most probably Goniatites globostriatus Zone, Late Viséan).

Material. Three sideritic specimens between 63 and $98 \mathrm{~mm}$ conch diameter from horizon $\mathrm{CeH}-1$ of the locality Chebket el Hamra-N.

Diagnosis. Goniatites with thickly discoidal to thinly pachyconic conch at $100 \mathrm{~mm}$ diameter $(\mathrm{ww} / \mathrm{dm}=0.50-0.55)$. Umbilicus very narrow (uw $/ \mathrm{dm}=0.15$ ); umbilical wall rounded. Ornamentation with crenulated biconvex and rectiradiate growth-lines with high dorsolateral projection and lower ventrolateral projection; external sinus deep. Approximately 180 spiral lines. Adult stage with coarse falcatoid ornament. Deep biconvex constrictions. Suture line with V-shaped (in juveniles) or Y-shaped (in adults), moderately narrow external lobe
( 0.60 of the external lobe depth, 1.20 of the adventive lobe), and moderate median saddle ( 0.45 of the external lobe depth). Flanks of the external lobe sharply incurved, ventrolateral saddle acute, adventive lobe V-shaped with almost straight flanks.

Description. Specimen MB.C.13255.1 is a beautiful individual with almost $100 \mathrm{~mm}$ diameter (Fig. 24). It is thickly discoidal $(\mathrm{ww} / \mathrm{dm}=0.53)$ with a very narrow umbilicus (uw $/ \mathrm{d}=0.14$ ) and a low aperture $(\mathrm{WER}=1.53)$. The conch appears to be laterally compressed with subparallel flanks that converge slowly toward the broadly rounded venter. The umbilical margin and the umbilical wall are rounded. Almost the entire
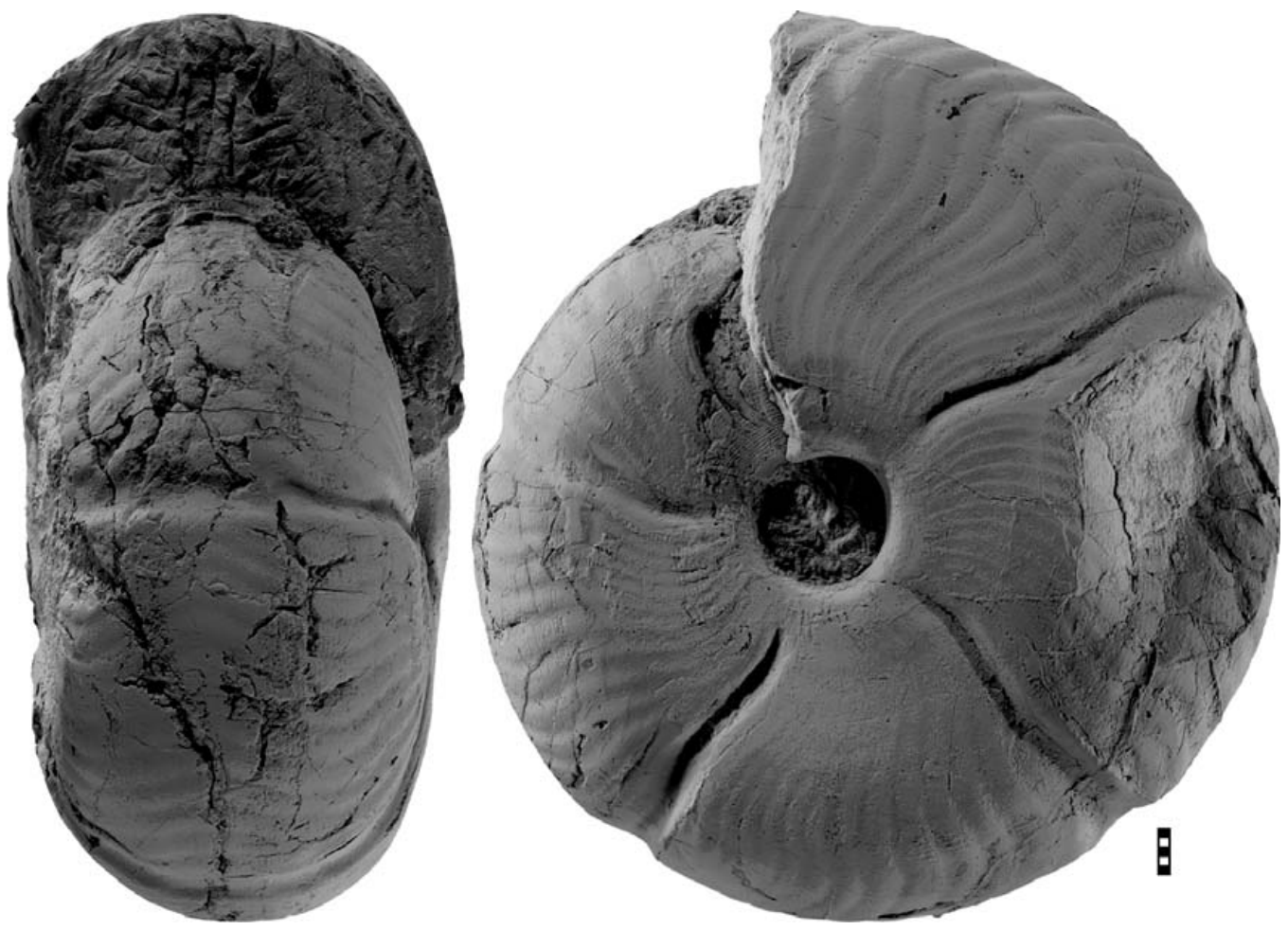

Figure 24. Goniatites globostriatus (Schmidt, 1925). Specimen MB.C.13255.1 from locality Chebket el Hamra-N; $\times 1.0$. 


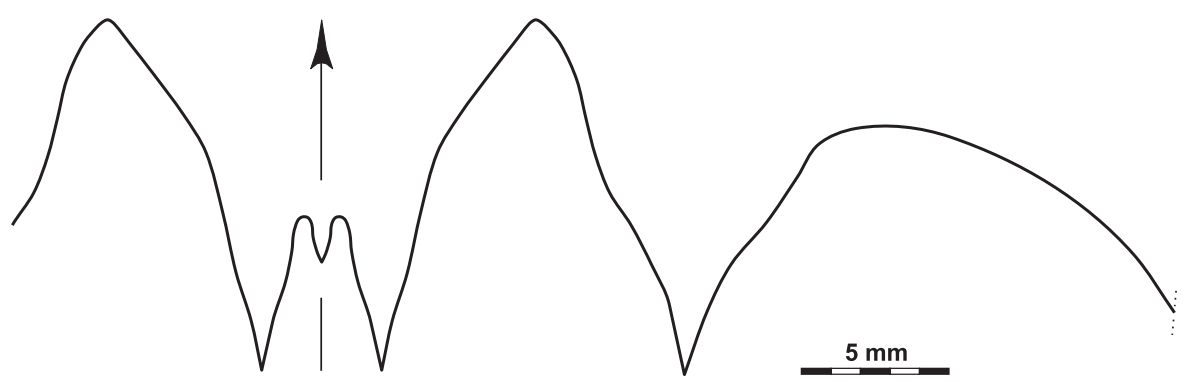

Figure 25. Goniatites globostriatus (Schmidt, 1925). Suture line of specimen MB.C.13255.2 from locality Chebket el Hamra-N, at $20 \mathrm{~mm}$ wh; $\times 3.0$. specimen is preserved as an internal mould with little shell remains. Impressions of the coarse ornament can be seen on the surface of the steinkern; they show that there is a combination of about 180 spiral lines with fine growth lines, which are periodically strengthened and produce a falcate ornament. The growth lines are strongly biconvex in their course with a rather prominent dorsolateral projection, a lower ventrolateral projection, and a rather deep ventral sinus. Deep constrictions with distances of approximately $75^{\circ}$ are visible on the steinkern; they do not run parallel to the growth lines but extend almost straight with a low dorsolateral projection across flanks and venter.

The suture line of specimen MB.C.13255.2 (20 mm whorl height) is typical for an adult specimen of Goniatites. It has an external lobe that shows the transformation from the V-shape into the Y-shape, with flanks possessing a conspicuous bend at two thirds of its height, and above which they strongly diverge (Fig. 25). The median saddle reaches 0.45 of the E lobe depth, and the secondary prongs of the E lobe are symmetric and narrowly V-shaped. The ventrolateral saddle is almost symmetric and acute, and the adventive lobe is Vshaped with slightly curved flanks.

Discussion. With this new discovery, the first representative of an adult specimen of Goniatites globostriatus can be shown. It clearly shows the differences with the probably contemporaneous species G. moorei Weyer, 1972 from the British Isles, which does not possess a falcatoid ornament in the adult stage (Korn \& Tilsley 2006).

Other species of Goniatites with a falcatoid ornament are G. spirifer Roemer, 1850, in which this type of ornament is not as strongly developed, and G. crenifalcatus Bogoslovskaya, 1966, in which the growth lines have a course with much higher ventrolateral projection.

\section{Subfamily Arnsbergitinae n. subfam.}

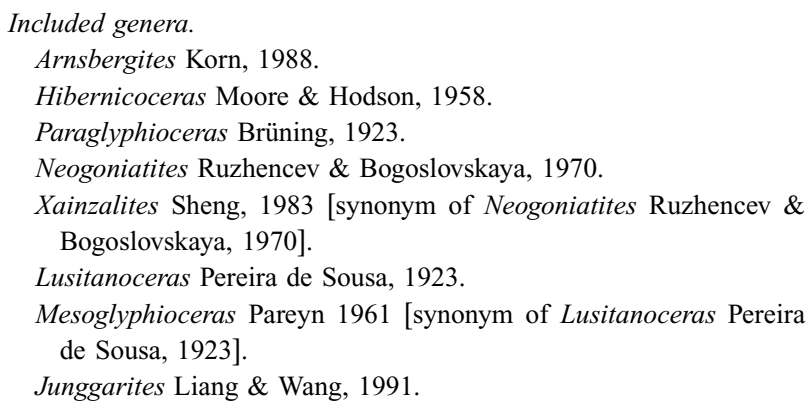

Discussion. The new subfamily is erected here for goniatitids with advanced conch morphology, displaying an ontogenetic development including a widely umbilicate stage for at least three whorls. Another separating criterion is the course of the growth lines in the late juvenile to preadult stage of many of the species, with a high ventral projection of the growth lines, which in representatives of the Goniatitinae is restricted to early juveniles.

\section{Arnsbergites Korn, 1988}

Type species. Goniatites falcatus Roemer, 1850.

Discussion. Seven valid species of Arnsbergites are listed in the AMMON database (Korn \& Ilg 2007). One of these, A. quinquagenarius (Hoeck, 1929) is based on crushed, poorly preserved material and thus very difficult to interpret. Of the remaining species, the three German species A.falcatus (Roemer, 1850), A. arnsbergensis (Brüning, 1923), and A. gracilis Korn, 1988 have been described with respect to their conch ontogeny (Korn 1988). For the three British and Irish species, the description of the inner whorls is still lacking.

The species of Arnsbergites can be grouped as follows:

A - species with falcate radial ornament:

A. falcatus (Roemer, 1850): with a thickly pachyconic conch $(\mathrm{ww} / \mathrm{dm}=0.75$ at $25 \mathrm{~mm} \mathrm{dm})$ and a coarse falcate ornament beginning at $25 \mathrm{~mm} \mathrm{dm}$;

A. sphaericostriatus (Bisat, 1924): with a thickly pachyconic conch $(\mathrm{ww} / \mathrm{dm}=0.75-0.85$ at $25 \mathrm{~mm}$ $\mathrm{dm}$ ), a weak falcate ornament beginning at $30 \mathrm{~mm}$ $\mathrm{dm}$, and a V-shaped external lobe that is very narrow at its base (0.30-0.35 of external lobe depth).

B - species without falcate radial ornament and a narrow external lobe (Fig. 26):

A. warslowensis (Bisat, 1957): with a thickly pachyconic to globular conch $(\mathrm{ww} / \mathrm{dm}=0.85$ at $25 \mathrm{~mm}$ $\mathrm{dm}$ ) and a V-shaped external lobe that is very narrow at its base (0.30-0.35 of external lobe depth), ventrolateral saddle subacute;

A. robustus (Moore \& Hodson, 1958): with a thickly pachyconic to globular conch $(\mathrm{ww} / \mathrm{dm}=0.85$ at $25 \mathrm{~mm} \mathrm{dm}$ ) and a V-shaped external lobe that is narrow at its base $(0.35-0.40$ of external lobe depth), ventrolateral saddle subacute; 


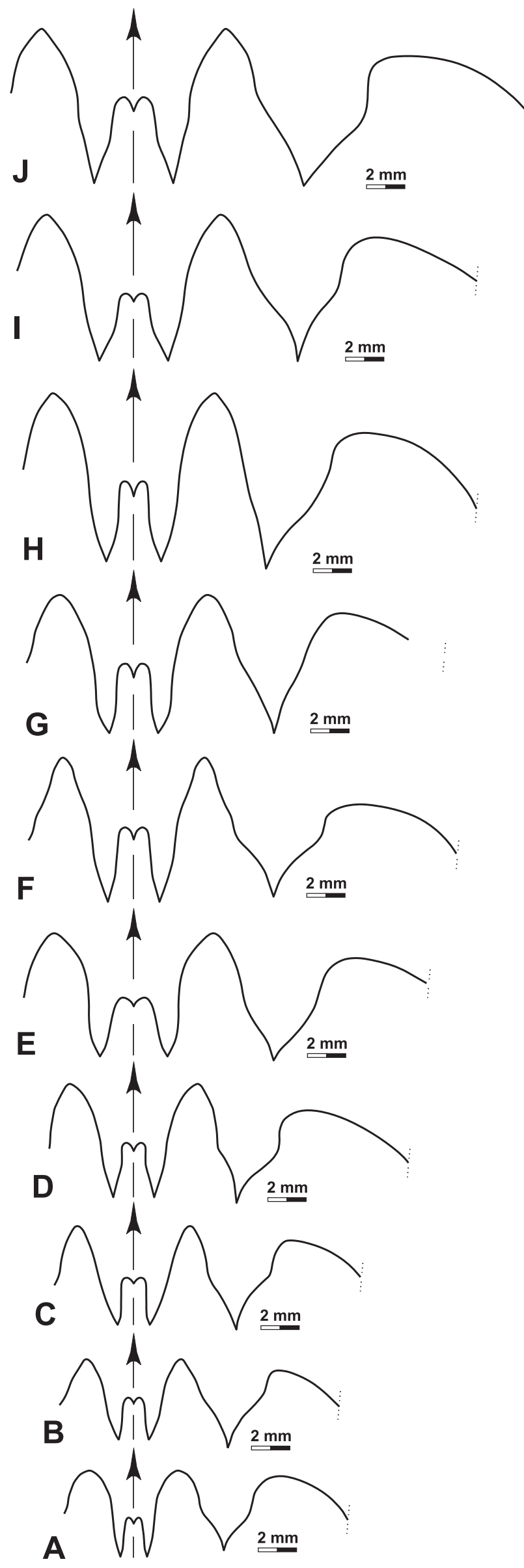

A. rufus n. sp.: with a thinly pachyconic conch (ww/ $\mathrm{dm}=0.60-0.65$ at $25 \mathrm{~mm} \mathrm{dm}$ ) and a V-shaped external lobe that is narrow at its base $(0.35-0.40$ of external lobe depth), ventrolateral saddle subacute;

A. proiecturus n. sp.: with a globular conch (ww/ $\mathrm{dm}=0.85-0.95$ at $25 \mathrm{~mm} \mathrm{dm})$ and a V-shaped external lobe that is very narrow at its base $(0.30$ 0.35 of external lobe depth), ventrolateral saddle rounded.

C - species without falcate radial ornament and a rather wide external lobe (Fig. 26):

A. arnsbergensis (Brüning, 1923): with a thickly pachyconic conch $(\mathrm{ww} / \mathrm{dm}=0.75$ at $25 \mathrm{~mm} \mathrm{dm})$ and a Y-shaped external lobe;

A. gracilis Korn, 1988: with a thickly pachyconic conch $(\mathrm{ww} / \mathrm{dm}=0.75$ at $25 \mathrm{~mm} \mathrm{dm})$ and a Vshaped external lobe that is moderately wide at its base ( $0.45-0.50$ of external lobe depth);

A. ferrus $\mathrm{n}$. sp.: with a thickly pachyconic conch (ww/ $\mathrm{dm}=0.75-0.85$ at $25 \mathrm{~mm} \mathrm{dm}$ ) and a V-shaped to Y-shaped external lobe that is moderately wide at its base ( 0.50 of external lobe depth).

\section{Arnsbergites sphaericostriatus (Bisat, 1924)}

Figures 27-29

1924 Goniatites sphaerico-striatus Bisat, p. 75.

1928 Goniatites waddingtoni Bisat, p. 131.

1936 Goniatites sphaerico-striatus. - Moore, p. 181, pl. 1, figs 6, 7.

1958 Goniatites sphaericostriatus. - Moore \& Hodson, p. 99, pl. 10, figs 6,7 .

Lectotype. Specimen GSM 71406 (Holmes Coll.).

Type locality and horizon. Dinckley Ferry, River Ribble (Lancashire, Great Britain); P1c Subzone (Late Viséan).

Figure 26. Suture lines of representatives of Arnsbergites, all $\times 3.0$. A. A. proiecturus n. sp., holotype MB.C.13219.1 from locality Chebket el Hamra-F, at $17.6 \mathrm{~mm} \mathrm{dm}, 15.9 \mathrm{~mm} \mathrm{ww}$, $6.5 \mathrm{~mm}$ wh. B. A. robustus (Moore \& Hodson, 1958), specimen GSM ZI5751 from Dough Mountain near Kiltyclogher (Ireland), at $16.3 \mathrm{~mm} \mathrm{dm}, 14.0 \mathrm{~mm}$ ww, $6.8 \mathrm{~mm}$ wh. C. A. warslowensis (Bisat, 1957), specimen GSM ZI5230 from Warslow Brook (Staffordshire), at $15.5 \mathrm{~mm} \mathrm{dm}, 15.2 \mathrm{~mm} \mathrm{ww}, 6.7 \mathrm{~mm}$ wh. D. Arnsbergites ferrus n. sp., paratype MB.C.13291.2 from Chebket el Hamra, at $19.2 \mathrm{~mm} \mathrm{dm}, 18.3 \mathrm{~mm}$ ww, $9.6 \mathrm{~mm}$ wh. E. A. arnsbergensis (Brüning, 1923), specimen MBG 4080 from Arnsberg (Rhenish Mountains), at $23.8 \mathrm{~mm} \mathrm{dm}, 20.1 \mathrm{~mm}$ ww, $12.1 \mathrm{~mm}$ wh. F. Arnsbergites rufus n. sp., paratype MB.C.13285.2 from Chebket el Hamra, at $28.2 \mathrm{~mm} \mathrm{dm}$, $18.6 \mathrm{~mm}$ ww, $6.5 \mathrm{~mm}$ wh. G. A. sphaericostriatus (Bisat, 1924), specimen GSM ZI2623 from Dough Mountain near Kilticlogher (Ireland), at $28.7 \mathrm{~mm} \mathrm{dm}, 21.8 \mathrm{~mm}$ ww, $13.0 \mathrm{~mm}$ wh. H. Arnsbergites sphaericostriatus (Bisat, 1924) n. sp., specimen MB.C.13290.1 from Chebket el Hamra, at $31.7 \mathrm{~mm} \mathrm{dm}$, $25.3 \mathrm{~mm}$ ww, $15.5 \mathrm{~mm}$ wh. I. A. gracilis Korn, 1988, specimen WMN 10122 from Holzen-Deinstrop (Rhenish Mountains), at $26.8 \mathrm{~mm} \mathrm{dm}, 19.5 \mathrm{~mm}$ ww, $11.6 \mathrm{~mm}$ wh. J. Arnsbergites ferrus n. sp., holotype MB.C.13291.1 from Chebket el Hamra, at $30.0 \mathrm{~mm} \mathrm{dm}, 24.7 \mathrm{~mm}$ ww, $16.4 \mathrm{~mm}$ wh. 

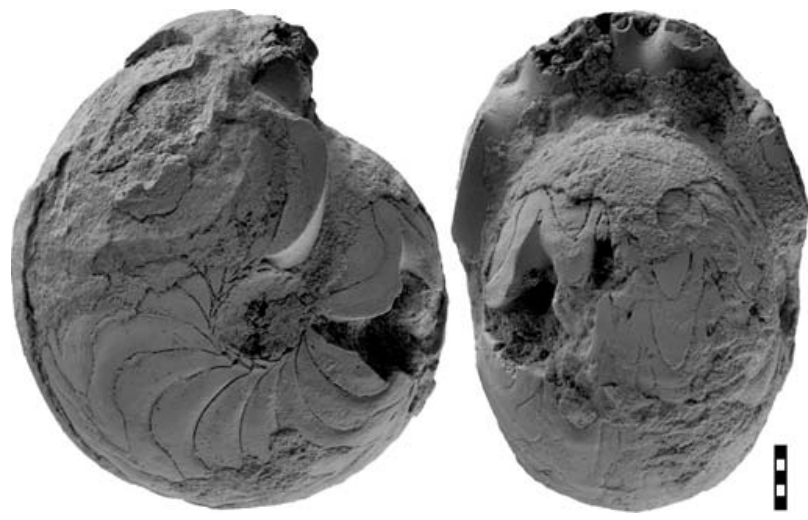

Figure 27. Arnsbergites sphaericostriatus (Bisat, 1924). Specimen MB.C.13290.1 from Chebket el Hamra; $\times 1.5$.

Material. 22 limonitic steinkern specimens ranging from 8 to $38 \mathrm{~mm}$ in conch diameter, from horizon $\mathrm{CeH}-2$ at localities Chebket el Hamra-F, I, T, and an unspecified locality.

Diagnosis. Arnsbergites with globular conch at $5 \mathrm{~mm}$ diameter (ww/ $\mathrm{dm}=0.85-0.95)$, globular conch at $10 \mathrm{~mm}$ diameter (ww/ $\mathrm{dm}=0.90-1.00)$, and thickly pachyconic conch at $25 \mathrm{~mm}$ diameter $(\mathrm{ww} / \mathrm{dm}=0.75-0.85)$. Umbilicus moderately wide to wide in early juveniles (uw/dm $=0.40-0.45$ at $2-5 \mathrm{~mm} \mathrm{dm}$ ) and continuously closing in later stages ( $\mathrm{uw} / \mathrm{dm}=0.10-0.15$ at $20 \mathrm{~mm} \mathrm{dm}$ ); umbilical margin and umbilical wall rounded. Ornamentation with 180 fine and granulated spiral lines. Suture line with V-shaped, moderately wide external lobe $(0.50-0.55$ of the external lobe depth; $1.00-1.10$ of the adventive lobe width), and moderate median saddle ( 0.45 of the external lobe depth). Flanks of the external lobe almost straight, ventrolateral saddle subacute to acute, adventive lobe with sinuous flanks.

Description. A cross section could only be produced from the small specimen MB.C.13234 (10 mm dm), but this displays the significant ontogenetic changes characteristic for the species (Fig. 28A). The early whorls have a wide umbilicus (uw/dm is more than 0.45 between 1.5 and $3.5 \mathrm{~mm} \mathrm{dm}$ ), which opens only slightly in the following whorls and thus leads to a rather rapid decrease of the $u w / d m$ ratio $(u w / d m=0.23$ at $10 \mathrm{~mm}$ $\mathrm{dm})$. The aperture is low in all stages $(\mathrm{WER}=1.50)$.

The largest specimen MB.C.13290.1 is a complete phragmocone specimen with $37 \mathrm{~mm}$ diameter but largely covered with an iron crust and bearing only few poorly preserved shell remains (Fig. 27). The conch is thinly pachyconic $(\mathrm{ww} / \mathrm{dm}=0.71)$ with a very narrow umbilicus $(u w / d m=0.14)$ and a very low aperture $($ WER $=1.53)$. The umbilical margin is rounded. On the internal mould and the iron crust, traces of a periodic strengthening of the growth lines are visible in the ventral and ventrolateral area; they suggest a falcate ornament.

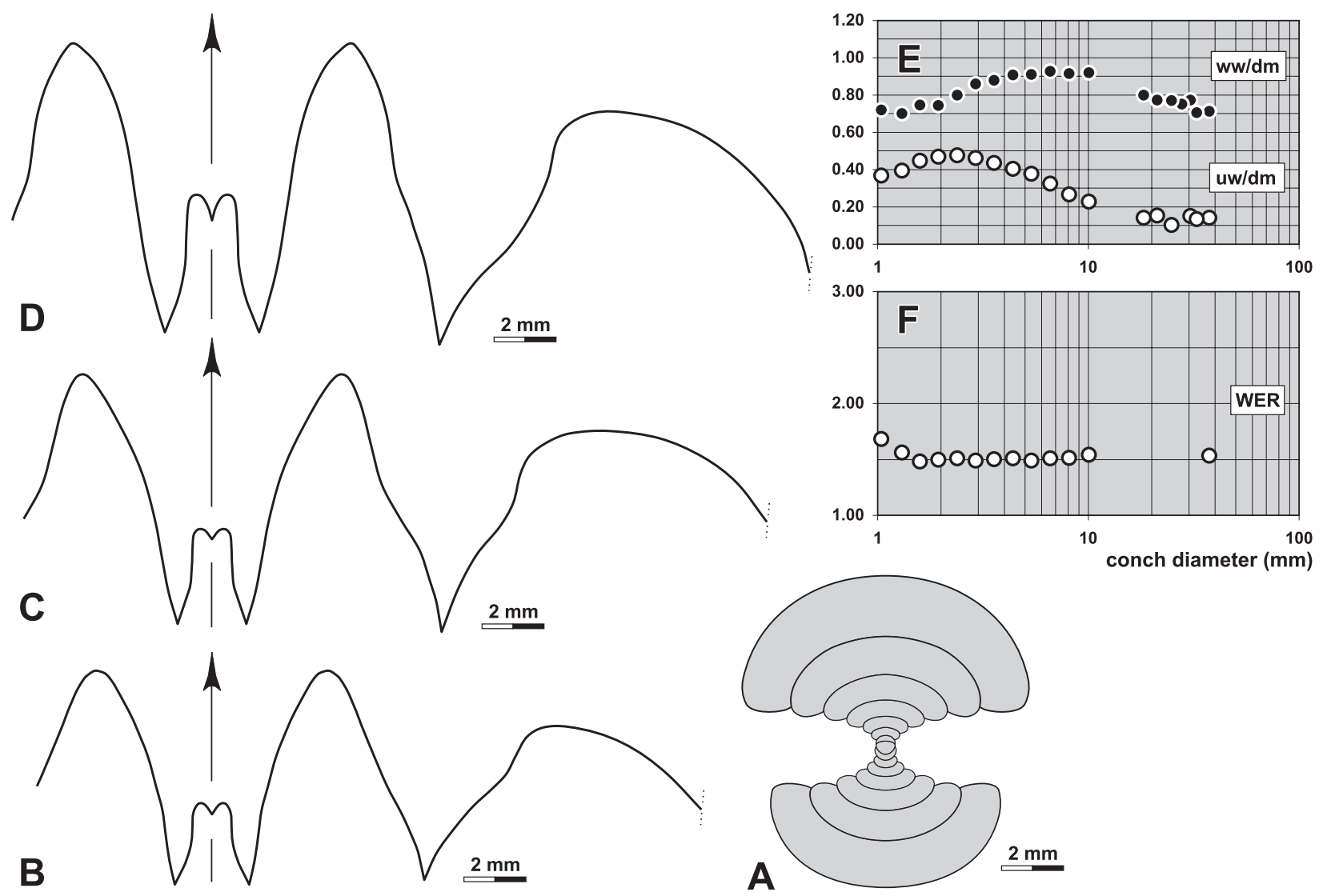

Figure 28. Arnsbergites sphaericostriatus (Bisat, 1924). A. Cross section of specimen MB.C.13234 from locality Chebket el Hamra-I; $\times$ 4.0. B. Suture line of specimen MB.C.13290.2 from Chebket el Hamra, at $22.0 \mathrm{~mm} \mathrm{dm}, 17.1 \mathrm{~mm}$ ww, $12.0 \mathrm{~mm}$ wh; $\times 4.0$. C. Suture line of specimen MB.C.13283 from Chebket el Hamra, at $27.5 \mathrm{~mm} \mathrm{dm}, 22.9 \mathrm{~mm} w w, 14.6 \mathrm{~mm}$ wh; $\times 4.0$. D. Suture line of specimen MB.C.13290.1 from Chebket el Hamra, at $31.7 \mathrm{~mm} \mathrm{dm}, 25.3 \mathrm{~mm}$ ww, $15.5 \mathrm{~mm}$ wh; $\times 4.0$. E, F. Ontogenetic development of the conch width index (ww/dm), umbilical width index (uw/dm) and whorl expansion rate (WER) of all available specimens. 


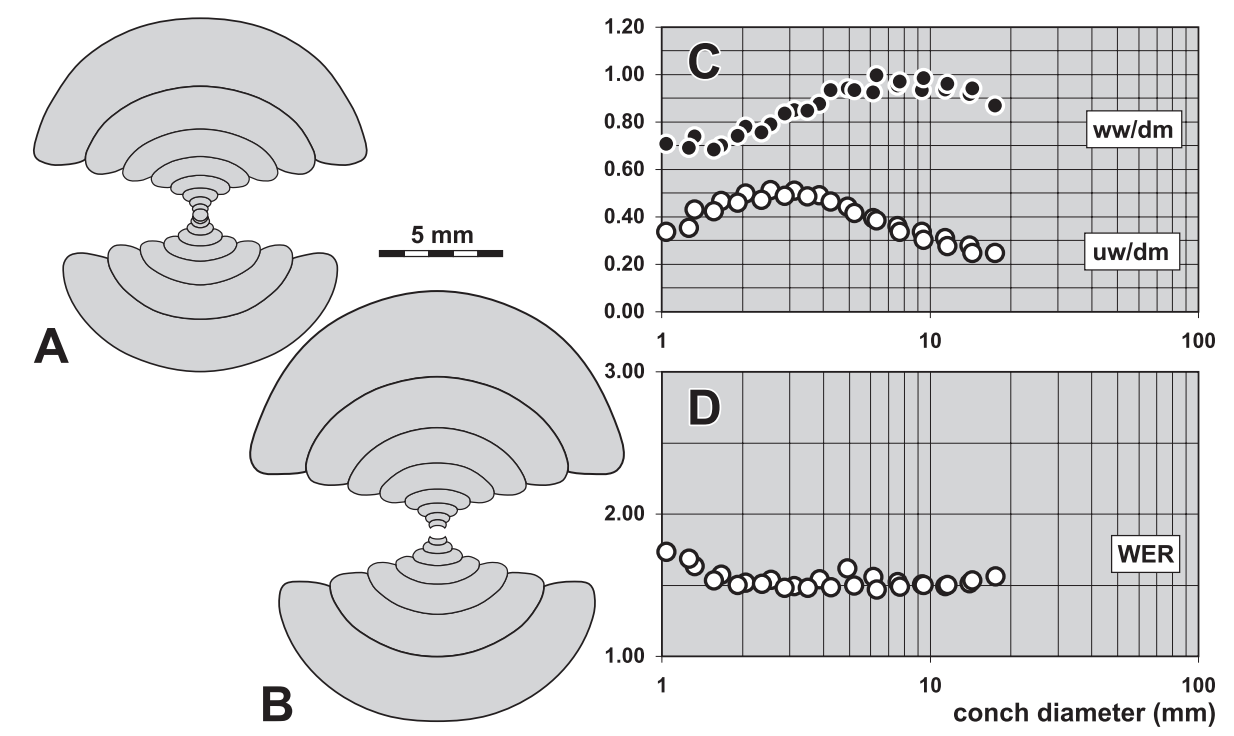

Figure 29. Arnsbergites sphaericostriatus (Bisat, 1924) from the highest of three horizons with Arnsbergites spp. at the base of the first shale member in the Carraun Shale Formation, north-western slope of Dough Mountain $3 \mathrm{~km}$ south-west of Kiltyclogher, Co. Leitrim, Ireland (Korn \& Ebbighausen 2007 Coll.). A. Cross section of specimen MB.C.13309.1; $\times 2.5$. B. Cross section of specimen MB.C.13309.2; $\times 2.5$. C, D. Ontogenetic development of the conch width index (ww/dm), umbilical width index (uw/ $\mathrm{dm})$ and whorl expansion rate (WER) of the two sectioned specimens.

The suture lines of the specimens are characterised by a narrow V-shaped external lobe, which has stronger diverging flanks in smaller specimens such as MB.C.13290.2 (22 mm dm; Fig. 28B). In the larger specimens MB.C.13283 (27.5 mm dm) and MB.C.13290.1 $(31.7 \mathrm{~mm} \mathrm{dm})$, the flanks tend to stand more parallel (Figs 28C, D). The ventrolateral saddle is almost symmetric in the three specimens, changing ontogenetically from subacute to acute. At the same time, the adventive lobe becomes narrower. This lobe has a weakly curved ventral and a more strongly curved dorsal flank.

Discussion. A. sphaericostriatus differs from similar species, such as A. gracilis, A. robustus, A. warslowensis, A. arnsbergensis, and A. ferrus in the presence of a weak falcate ornament at a conch diameter of $35 \mathrm{~mm}$. A. sphaericostriatus belongs with the other species of the genus that have a narrow external lobe, which is a good criterion for separating it from species with a similar conch geometry, such as A. gracilis and A. ferrus.

\section{Arnsbergites ferrus n. sp.}

Figures 30-31

Derivation of name. After Latin ferrus $=$ sword, because of the shape of the prongs of the external lobe.

Holotype. Specimen MB.C.13291.1 (Ebbighausen \& Weyer 2007 Coll.); illustrated in Figure 30A.

Type locality and horizon. Chebket el Hamra (Jerada Basin, NE-Morocco); horizon CeH-2, Arnsbergites gracilis or Neoglyphioceras spirale Zone (middle Brigantian, Early Carboniferous).

Material. 38 limonitic steinkern specimens between 8 and $31 \mathrm{~mm}$ conch diameter from horizon CeH-2 at localities Chebket el Hamra-F, $\mathrm{I}, \mathrm{T}$, and an unspecified locality.
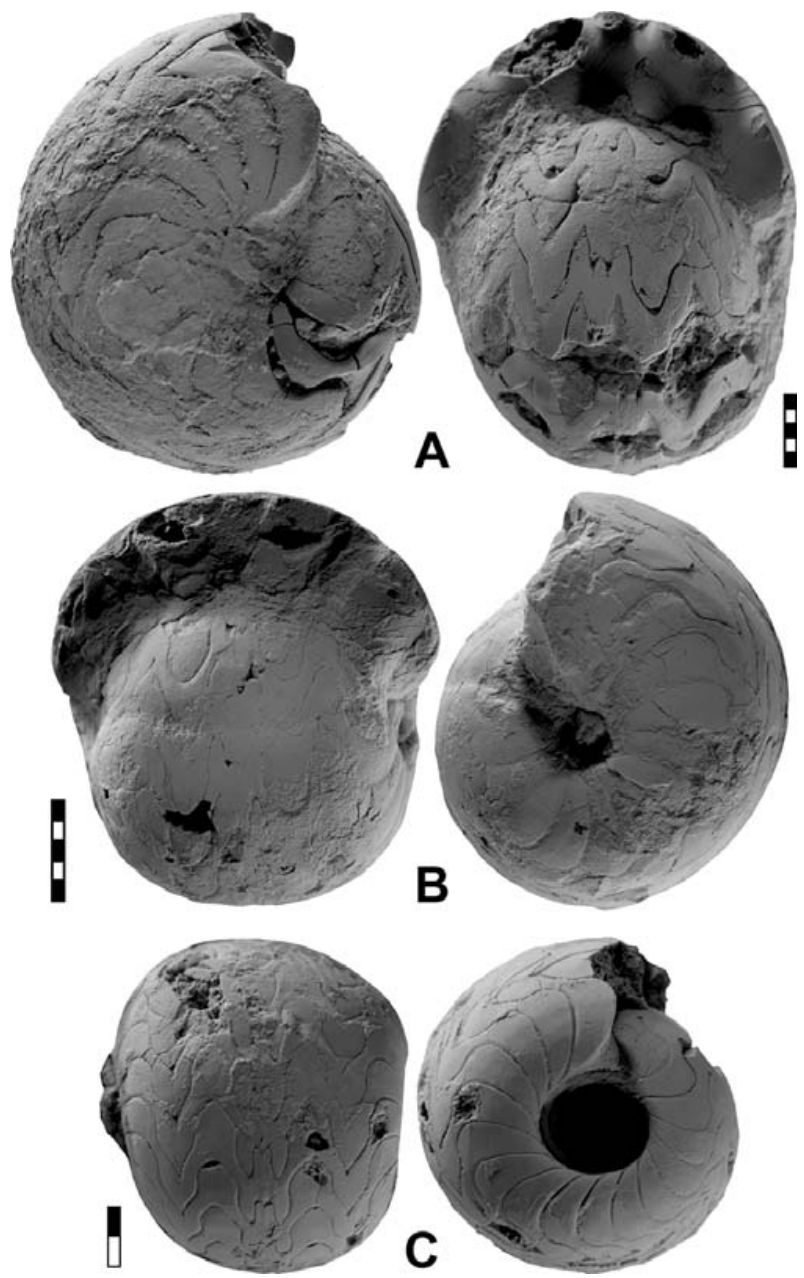

Figure 30. Arnsbergites ferrus

n. sp. A. Holotype MB.C.13291.1 from Chebket el Hamra; $\times 1.5$. B. Specimen MB.C.13291.2 from Chebket el Hamra; $\times 2.0$. C. Paratype MB.C.13218.1 from locality Chebket el Hamra-F; $\times 3.0$. 


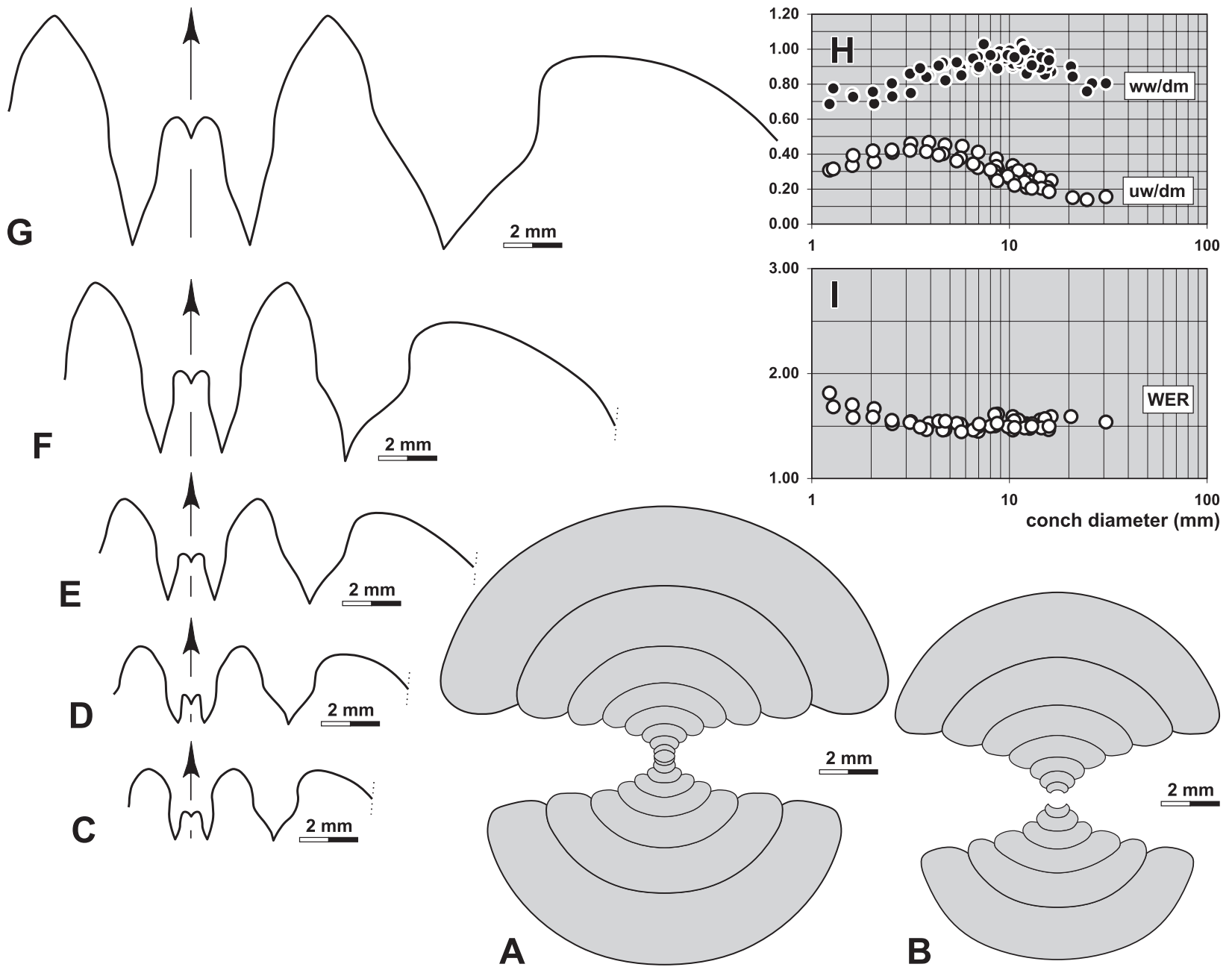

Figure 31. Arnsbergites ferrus n. sp. A. Cross section of paratype MB.C.13274.1 from locality Chebket el Hamra-T; $\times 4.0$. B. Cross section of paratype MB.C.13218.2 from locality Chebket el Hamra-F; × 4.0. C. Suture line of paratype MB.C.13218.1 from locality Chebket el Hamra-F, at $10.2 \mathrm{~mm} \mathrm{dm}, 9.2 \mathrm{~mm}$ ww, $4.2 \mathrm{~mm}$ wh; $\times 4.0$. D. Suture line of paratype MB.C.13218.3 from locality Chebket el Hamra-F, at $11.1 \mathrm{~mm} \mathrm{dm}, 11.2 \mathrm{~mm}$ ww, $4.3 \mathrm{~mm}$ wh; $\times 4.0$. E. Suture line of paratype MB.C.13218.4 from locality Chebket el Hamra-F, at $14.9 \mathrm{~mm} \mathrm{dm}, 13.1 \mathrm{~mm}$ ww, $6.3 \mathrm{~mm}$ wh; $\times 4.0$. F. Suture line of paratype MB.C.13291.2 from Chebket el Hamra, at $19.2 \mathrm{~mm} \mathrm{dm}, 18.3 \mathrm{~mm}$ ww, $9.6 \mathrm{~mm}$ wh; $\times 4.0$. G. Suture line of holotype MB.C.13291.1 from Chebket el Hamra, at $30.0 \mathrm{~mm} \mathrm{dm}, 24.7 \mathrm{~mm}$ ww, $16.4 \mathrm{~mm}$ wh; $\times 4.0$. H, I. Ontogenetic development of the conch width index (ww/dm), umbilical width index (uw/dm) and whorl expansion rate (WER) of all available specimens.

Diagnosis. Arnsbergites with globular conch at $5 \mathrm{~mm}$ diameter (ww/ $\mathrm{dm}=0.85-0.95)$, globular conch at $10 \mathrm{~mm}$ diameter $\quad(\mathrm{ww} /$ $\mathrm{dm}=0.90-1.00$ ), and thickly pachyconic conch at $25 \mathrm{~mm}$ diameter $(\mathrm{ww} / \mathrm{dm}=0.75-0.85)$. Umbilicus moderately wide to wide in early juveniles (uw/dm $=0.40-0.50$ at $2-5 \mathrm{~mm} \mathrm{dm}$ ) and continuously closing in later stages (uw $/ \mathrm{dm}=0.20-0.25$ at $15 \mathrm{~mm} \mathrm{dm}$ ); umbilical margin and umbilical wall rounded. Ornamentation with 180 fine and granulated spiral lines. Suture line with V-shaped to Y-shaped, moderately wide external lobe $(0.60-0.70$ of the external lobe depth; 1.10 of the adventive lobe width), and moderate median saddle ( 0.50 of the external lobe depth). Flanks of the external lobe slightly sinuous, ventrolateral saddle subacute, adventive lobe with sinuous flanks.

Description. The plot displaying the ontogeny of the cardinal conch parameters shows that the ontogenetic trends of the $\mathrm{ww} / \mathrm{dm}$ ratio and the $\mathrm{uw} / \mathrm{dm}$ ratio are unrelated, and that it is thus not possible to distinguish between distinct growth stages (Fig. 31H). The development of the conch width shows two phases. In the first growth interval, ranging up to about $11 \mathrm{~mm} \mathrm{dm}$, a continuous increase of the $\mathrm{ww} / \mathrm{dm}$ ratio can be seen from $0.70-0.75$ at $2 \mathrm{~mm}$ dm to $0.90-1.00$ at $11 \mathrm{~mm}$. A reverse development, i.e. a decrease of the ww/dm ratio to $\mathrm{ww} / \mathrm{dm}=0.80$ occurs the second growth interval. In the uw/dm ratio, also two growth intervals can be seen, but the first one is much shorter. The uw/dm ratio increases up to $4 \mathrm{~mm}$ conch diameter (uw/ $\mathrm{dm}=0.42-$ 0.47 ); thereafter, an almost continuous decrease to approximately 0.15 at $20 \mathrm{~mm} \mathrm{dm}$ can be seen. The aperture is very low in all stages above $2 \mathrm{~mm}$ conch diameter; the whorl expansion rate ranges between 1.50 and 1.60 (Fig. 31I).

A number of cross sections were produced to outline the ontogenetic changes, the intraspecific variability, and the differences with the co-occurring species of Arnsbergites (Figs 31A, B). The most complete of these is paratype MB.C.13274.1 with a maximum diameter 


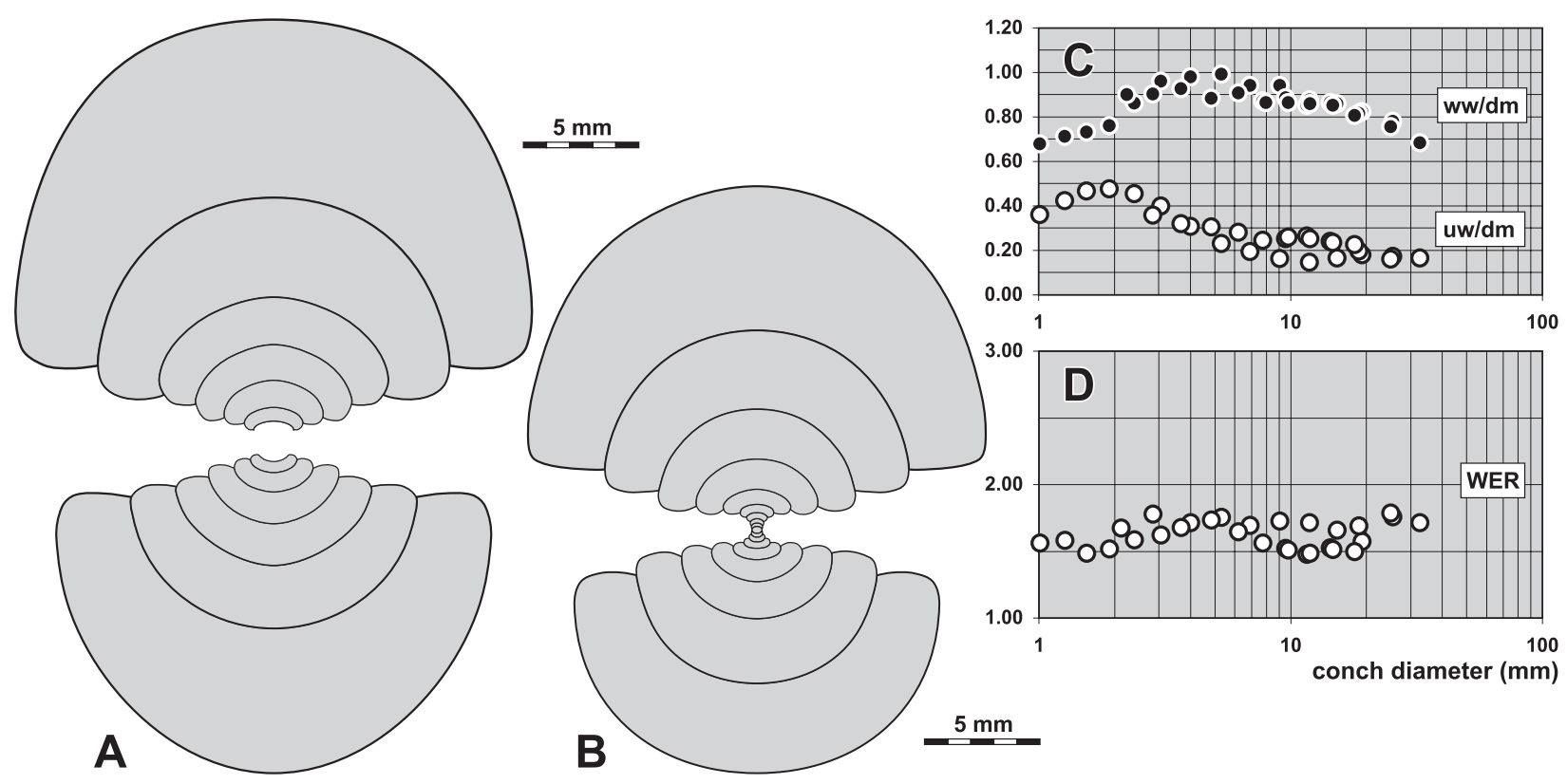

Figure 32. Arnsbergites gracilis Korn, 1988 from the Rhenish Mountains. A. Cross section of specimen MB.C.13300 from Nehden (Korn 1987 Coll.); $\times 2.5$. B. Cross section of specimen MB.C.13304 from the Eulenspiegel (Korn 1983 Coll.); $\times 2.5$. C, D. Ontogenetic development of the conch width index (ww/dm), umbilical width index (uw/dm) and whorl expansion rate (WER) of the sectioned specimens MB.C.13300, MB.C.13304, and the topotype (not figured) MB.C.13298.

of almost $16 \mathrm{~mm}$. It demonstrates the conspicuous ontogenetic changes, beginning with an open umbilicate conch with crescent-shaped whorl section, being transformed into C-shaped sections in later stages. The venter is broad and continuously rounded in all stages, and the umbilical margin is narrowly rounded.

Holotype MB.C.13291.1 (30 mm conch diameter) is the largest available specimen (Fig. 30A). It is fully chambered and slightly deformed tectonically. Most of the specimen is covered by an iron hydroxide crust, and ornament traces are thus only barely visible. The specimen is thickly pachyconic $(\mathrm{ww} / \mathrm{dm}=0.81)$, a narrow umbilicus (uw/dm $=0.16$ ), and a very low aperture $(\mathrm{WER}=1.54)$. The flanks and venter are continuously rounded. Some impressions of the ornament are visible near the aperture; they show fine spiral lines.

Other slightly deformed specimens are paratypes MB.C.13284.1 (24 mm dm) and MB.C.13291.2 (20 mm $\mathrm{dm}$ ). The first of these is thickly pachyconic (ww/ $\mathrm{dm}=0.78)$ and bears some shell remains. Its ornament is composed of fine and delicately granulated spiral lines, which are almost as wide as their interspaces. Constrictions are absent on the steinkern. The smaller paratype MB.C.13291.2 is globular $(\mathrm{ww} / \mathrm{dm}=0.90)$ with continuously rounded flanks and venter and a rounded umbilical margin (Fig. 30B). The specimen shows one almost linear constriction of the steinkern with a very low and wide ventral projection near the beginning of the last whorl.

Almost all specimens smaller than $16 \mathrm{~mm} \mathrm{dm}$ are globular and widely umbilicate. For instance, specimen MB.C.13218.4 has, at $16 \mathrm{~mm} \mathrm{dm}$, an umbilicus of one quarter of the conch diameter. This ratio is 0.31 in spe- cimen MB.C.13218.1 (11 $\mathrm{mm} \mathrm{dm})$ and 0.36 in specimen MB.C.13218.5 (9.5 $\mathrm{mm} \mathrm{dm})$. None of these three specimens shows constrictions of the steinkern.

A series of suture lines has been drawn to outline the ontogenetic changes and variability between various specimens. For this purpose, the five paratypes MB.C.13218.1 (10 mm dm), MB.C.13218.3 (11 mm $\mathrm{dm})$, MB.C.13218.4 (15 mm dm), MB.C.13291.2 $(19 \mathrm{~mm} \mathrm{dm})$, and MB.C.13291.1 (30 $\mathrm{mm} \mathrm{dm})$ are illustrated here (Figs 31C-G). Several general ontogenetic trends can be seen, (1) the heightening of the median saddle (less than 0.40 of the E lobe depth at $11 \mathrm{~mm}$ $\mathrm{dm} ; 0.56$ at $30 \mathrm{~mm} \mathrm{dm}$ ), (2) the transformation of a Yshaped external lobe in juveniles into a more V-shaped in adults, (3) the loss of pouching of the lower half of the external lobe, (4) the transformation of a rounded ventrolateral saddle into a subacute. It is only the adventive lobe that has a very similar outline in the studied growth interval of the specimens, possessing a gently curved ventral and a stronger curved dorsal flank.

Discussion. A.ferrus is the most common species of Arnsbergites at Chebket el Hamra. It differs from A. proiecturus in having stronger sinuous flanks of the external lobe, a subacute ventrolateral saddle, and in the narrower umbilicus in the intermediate stage. A. sphaericostriatus has a narrower conch than A. ferrus and a suture line with a much narrower external lobe.

Arnsbergites gracilis has a similar suture line with wide external lobe, but with a narrower conch and a narrower umbilicus in the intermediate stage (Fig. 32). A. robustus has a similar conch geometry, but possesses 


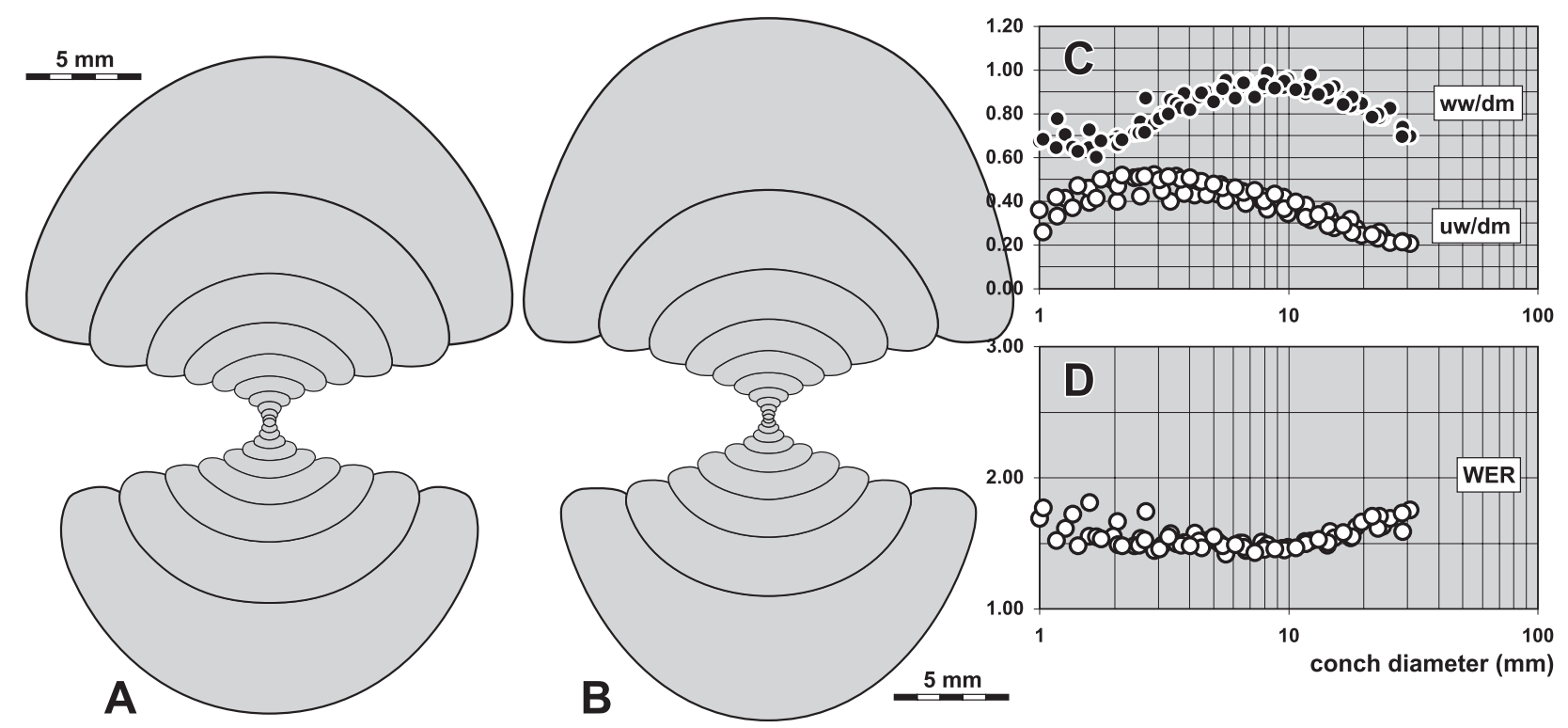

Figure 33. Arnsbergites robustus (Moore \& Hodson, 1958) from the Rhenish Mountains. A. Cross section of specimen MB.C.13306 from the Biesenberg (Korn 1983 Coll.); $\times 2.5$. B. Cross section of specimen MB.C.13301 from Nehden (Korn 1986 Coll.); $\times 2.5$. C, D. Ontogenetic development of the conch width index (ww/dm), umbilical width index (uw/dm) and whorl expansion rate (WER) of the four sectioned specimens MB.C.13302, MB.C.13301, MB.C.13305, and MB.C.13306.

a wider umbilicus and a narrower external lobe. Specimens of A. robustus from the Rhenish Mountains (Fig. 33) show that the ontogeny of the conch parameters is very similar.

\section{Arnsbergites proiecturus n. sp.}

Figures 34-36

Derivation of name. From Latin proiecturus $=$ projection, because of the course of the growth lines.

Holotype. Specimen MB.C.13219.1 (Korn \& Ebbighausen 2006 Coll.); illustrated in Figure 34A.

Type locality and horizon. Chebket el Hamra-F (Jerada Basin, NEMorocco); horizon $\mathrm{CeH}-2$, most probably Neoglyphioceras spirale Zone (middle Brigantian, Early Carboniferous).

Material. Five limonitic steinkern specimens ranging from 9 to $19 \mathrm{~mm}$ in conch diameter from horizon $\mathrm{CeH}-2$ at locality Chebket el Hamra-F.

Diagnosis. Arnsbergites with thickly pachyconic conch at $5 \mathrm{~mm}$ diameter $(\mathrm{ww} / \mathrm{dm}=0.75-0.85)$, globular conch at $10 \mathrm{~mm}$ diameter ( $w w /$ $\mathrm{dm}=0.85-0.95$ ), and globular conch at $25 \mathrm{~mm}$ diameter (ww/ $\mathrm{dm}=0.85-0.95)$. Umbilicus wide in early juveniles $(\mathrm{uw} / \mathrm{dm}=0.45-$ 0.50 at $2-5 \mathrm{~mm} \mathrm{dm}$ ) and continuously becoming narrower in later stages $(\mathrm{uw} / \mathrm{dm}=0.30$ at $20 \mathrm{~mm} \mathrm{dm}$ ); umbilical margin subangular, umbilical wall flattened. Ornamentation with fine and granulated spir- al lines. Suture line with Y-shaped, moderately narrow external lobe ( 0.50 of the external lobe depth; 0.90 of the adventive lobe width), and moderate median saddle ( 0.45 of the external lobe depth). Flanks of the external lobe slightly sinuous, ventrolateral saddle rounded, adventive lobe with sinuous flanks.

Description. The small sectioned paratype MB.C.13219.3 (Fig. 35A) shows the serpenticonic inner whorls $(\mathrm{ww} / \mathrm{dm}=0.50, \mathrm{uw} / \mathrm{dm}=0.46$ at $2 \mathrm{~mm} \mathrm{dm})$, which are transformed into a cadyconic shape that is present from 5 to $11 \mathrm{~mm}$ conch diameter (ww/ $\mathrm{dm}=0.86, \mathrm{uw} / \mathrm{dm}=0.36$ at $11 \mathrm{~mm} \mathrm{dm})$. The aperture is low in this growth interval, with a whorl expansion rate of 1.50 (Figs 35D, E).

The largest available specimen, holotype MB.C.13219.1 (Fig. 34A) has $18.6 \mathrm{~mm}$ conch diameter and is globular $(\mathrm{ww} / \mathrm{dm}=0.92)$ with a moderate umbilicus $(\mathrm{uw} / \mathrm{dm}=0.31)$. It has a subangular umbilical margin and a flattened and steep umbilical wall. Almost the entire specimen represents the body chamber, but the last suture line is only barely visible, probably due to incomplete mineralization of the septum. Two steinkern constrictions, arranged in opposite position, extend with a shallow lateral sinus and a wide rounded ventral projection. Traces of growth lines show the same
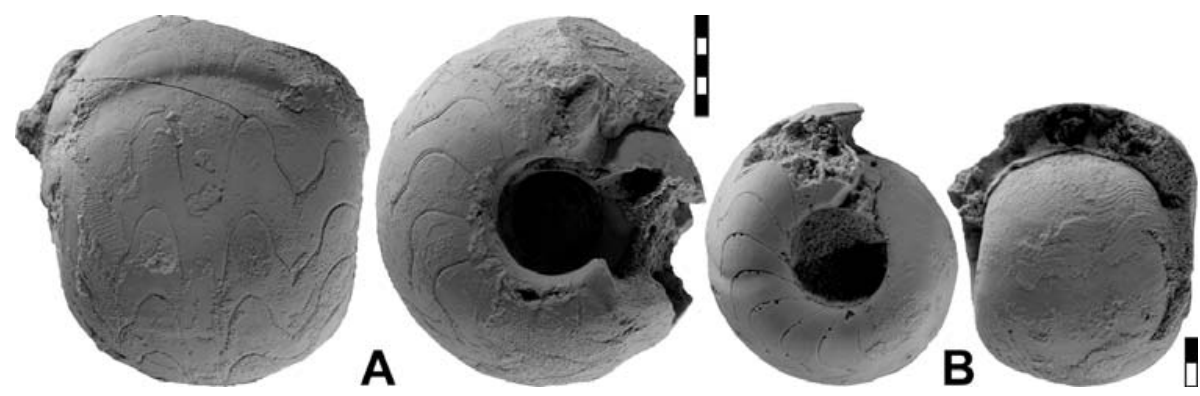

Figure 34. Arnsbergites proiecturus n. sp. A. Holotype MB.C.13219.1 from locality Chebket el Hamra-F; $\times 2.0$. B. Paratype MB.C. 13219.2 from locality Chebket el Hamra-F; $\times 2.5$. 

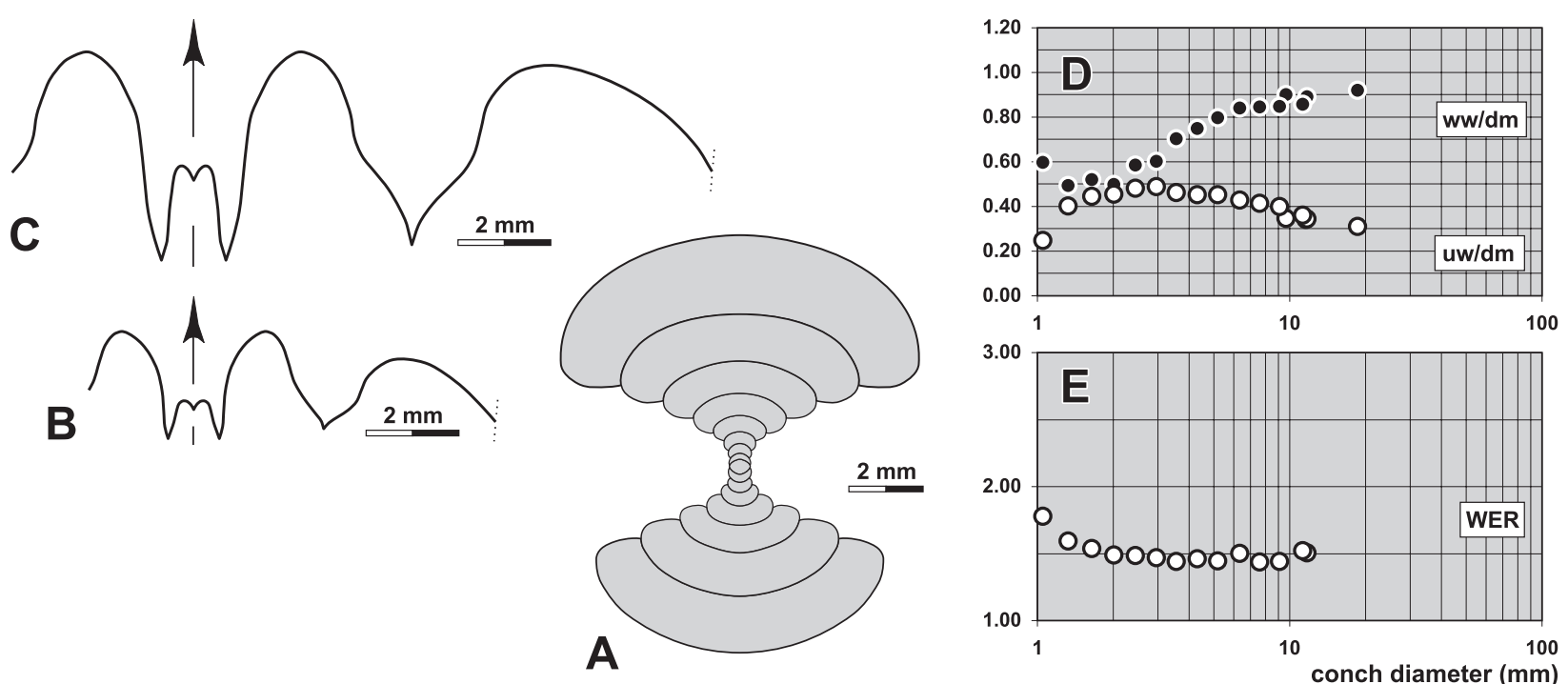

Figure 35. Arnsbergites proiecturus n. sp. A. Cross section of paratype MB.C.13219.3 from locality Chebket el Hamra-F; $\times 4.0$. B. Suture line of paratype MB.C.13219.2 from locality Chebket el Hamra-F, at $11.0 \mathrm{~mm} \mathrm{dm,} 9.9 \mathrm{~mm}$ ww, $4.1 \mathrm{~mm}$ wh; $\times 5.0$. C. Suture line of holotype MB.C.13219.1 from locality Chebket el Hamra-F, at $17.6 \mathrm{~mm} \mathrm{dm}, 15.9 \mathrm{~mm}$ ww, $6.5 \mathrm{~mm}$ wh; $\times 5.0$. D, E. Ontogenetic development of the conch width index (ww/dm), umbilical width index (uw/dm) and whorl expansion rate (WER) of all available specimens.

course, yielding evidence that, at this diameter, a ventral sinus had not yet developed. The sparse shell remains around the umbilicus show delicate spiral lines.

Paratype MB.C.13219.2 (11.7 mm dm; Fig. 34B) has similar conch geometry with a globular form (ww/ $\mathrm{dm}=0.89)$ and a moderate umbilicus $(\mathrm{uw} / \mathrm{dm}=0.35)$. One visible steinkern constriction follows a course in which the rounded and wide ventral projection is the dominant element. Shell remains at the beginning of the last whorl show rather coarse growth lines, which bend strongly forward to form a broad and flattened ventral projection.

The suture line of the holotype MB.C.13219.1 (drawn at $17.5 \mathrm{~mm} \mathrm{dm}$; Fig. 35B) has a rather narrow external lobe that has a width, at half depth, of half of the lobe depth, being narrower than the narrowly rounded ventrolateral saddle. The flanks of the external lobe are straight in the lower three quarters and form

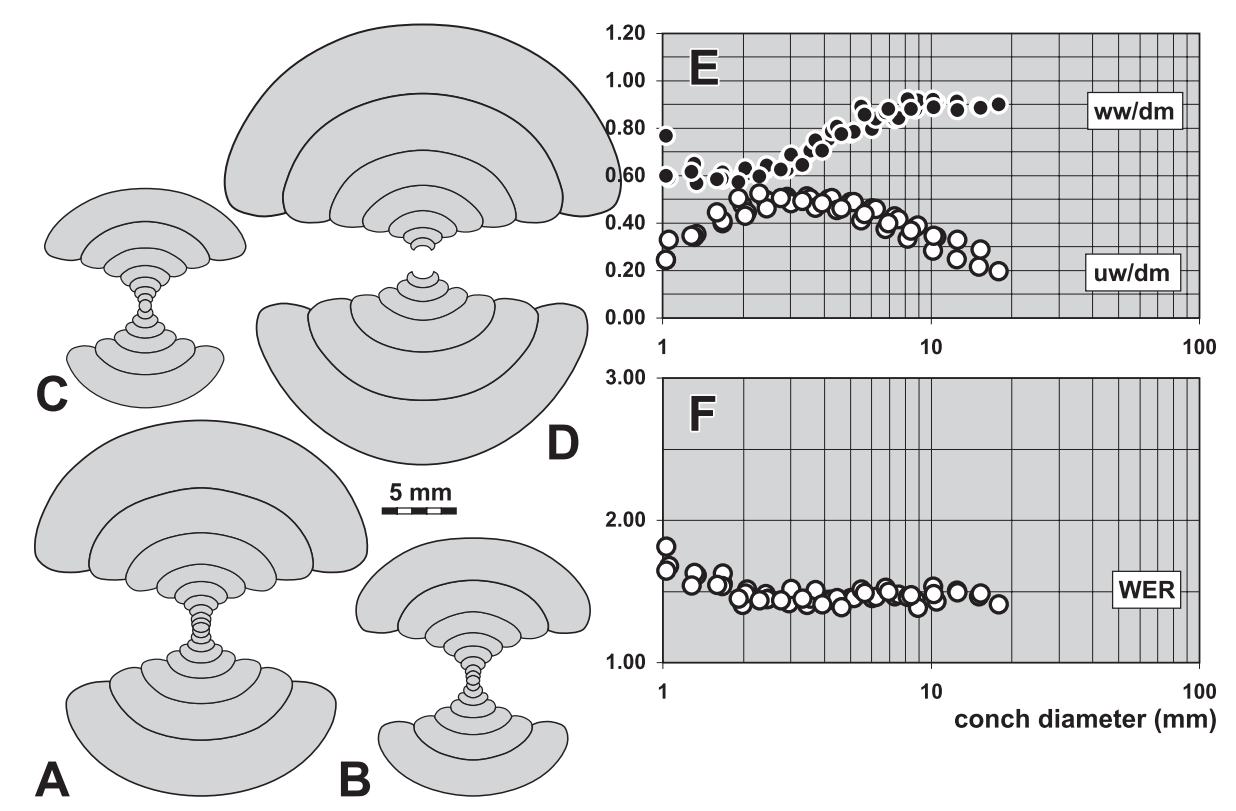

Figure 36. Arnsbergites proiecturus n. sp. from bed 144 of the Praia de Murração section (B) and from bed 134 of the Praia das Quebradas section (A, C, D), SW Portugal (Korn \& Horn 1995 Coll.). A. Cross section of specimen MB.C.13311.1; × 2.5. B. Cross section of specimen MB.C. $13312 ; \times 2.5$. C. Cross section of specimen MB.C.13311.2; $\times 2.5$. D. Cross section of specimen MB.C.13311.3; $\times 2.5$. E, F. Ontogenetic development of the conch width index (ww/dm), umbilical width index (uw/dm) and whorl expansion rate (WER) of the four sectioned specimens. 
narrow prongs together with the flanks of the median saddle that reaches 0.46 of the E lobe depth. The adventive lobe has rather strongly curved flanks.

The suture line of the juvenile paratype MB.C.13219.2 $(11 \mathrm{~mm} \mathrm{dm})$ has a Y-shaped external lobe with slightly diverging flanks in the lower half (Fig. 35C). The ventrolateral saddle is asymmetric and narrowly rounded, and the adventive lobe is wide with curved flanks.

Discussion. In conch shape and course of the constrictions, the new material from Chebket el Hamra closely resembles material from the South Portuguese Zone (Fig. 36) and the type specimen of 'Goniatites robustus Moore \& Hodson, 1958. However, the suture line of the Irish species has a subacute ventrolateral saddle with strongly converging flanks, whereas in A. proiecturus the ventrolateral saddle is rather broadly rounded.

A. proiecturus differs from the other Moroccan species of Arnsbergites in the much wider umbilicus in comparable stages. Furthermore, it differs from the others in the presence of a ventral projection of the growth lines in a rather large conch diameter of $18 \mathrm{~mm}$ (i.e. the absence of a ventral sinus). The narrow external lobe is another clear distinguishing character from $A$. ferrus.

\section{Arnsbergites rufus n. sp.}

Figures 37-38

Derivation of name. From Latin rufus $=$ red, after the colour of the specimens and the shales from which they derive.

Holotype. Specimen MB.C.13285.1 (Korn \& Ebbighausen 2006 Coll.); illustrated in Figure 37A.

Type locality and horizon. Chebket el Hamra (Jerada Basin, NE-Morocco); horizon CeH-2, Arnsbergites gracilis or Neoglyphioceras spirale Zone (middle Brigantian, Early Carboniferous).

Material. Seven limonitic specimens ranging from 23 and $38 \mathrm{~mm}$ conch diameter from horizon $\mathrm{CeH}-2$ of an unspecified locality at the Chebket el Hamra.

Diagnosis. Arnsbergites with thickly pachyconic conch at $20 \mathrm{~mm}$ diameter $(\mathrm{ww} / \mathrm{dm}=0.80-0.85)$ and thinly pachyconic conch at $25 \mathrm{~mm}$ diameter $(\mathrm{ww} / \mathrm{dm}=0.60-0.65)$. Umbilicus very narrow at $20-35 \mathrm{~mm}$ $\mathrm{dm} \quad(\mathrm{uw} / \mathrm{dm}=0.05-0.15)$; umbilical margin and umbilical wall rounded. Ornamentation with 150 lamellose and granulated spiral lines. Suture line with V-shaped, moderately wide external lobe $(0.60$ of the external lobe depth; 1.00 of the adventive lobe width), and moderate median saddle ( 0.50 of the external lobe depth). Flanks of the external lobe sinuous, ventrolateral saddle subacute, adventive lobe with sinuous flanks.

Description. None of the specimens shows the internal whorls, and they are not preserved in the sectioned specimen MB.C.13285.3 (Fig. 38A). The last whorl however shows the laterally slightly compressed whorl cross section, in which flanks and venter are separated by a broadly rounded ventrolateral shoulder.

Holotype MB.C.13285.1 is a well preserved haematitic specimen on which many shell remains are still attached (Fig. 37A). It has a diameter of $37.5 \mathrm{~mm}$, it is thinly pachyconic $(\mathrm{ww} / \mathrm{dm}=0.61)$ and laterally compressed with a very narrow umbilicus $(\mathrm{uw} / \mathrm{dm}=0.11)$ and a low aperture $(\mathrm{WER}=1.56)$. The well-preserved ornament consists of approximately 150 lamellose and faintly granulated spiral lines and growth lines, which extend with equally high lateral projections and a wide and shallow ventral sinus.

Paratype MB.C.13285.2 (32.5 mm dm; Fig. 37B) has a similar applanate shape $(\mathrm{ww} / \mathrm{dm}=0.64)$. It is slightly deformed and fully septate with 15 chambers. The steinkern bears one very shallow constriction, extending straight across flanks and venter.

The suture line of paratype MB.C.13285.2 (drawn at $28 \mathrm{~mm} \mathrm{dm}$ ) has a V-shaped external lobe with doublecurved flanks diverging towards the narrow, slightly asymmetric and subacute ventrolateral saddle (Fig. 38B). The median saddle reaches about the half height of the external lobe, producing two narrow and symmetric prongs of the E lobe.

Discussion. Arnsbergites rufus differs from the other species of the genus by its slender, laterally compressed conch shape. At $25 \mathrm{~mm}$ conch diameter, the ww/dm ratio is only $0.60-0.65$ in $A$. rufus, whereas all other species show a ratio of at least 0.75 . It is thus easily separable from the other species.
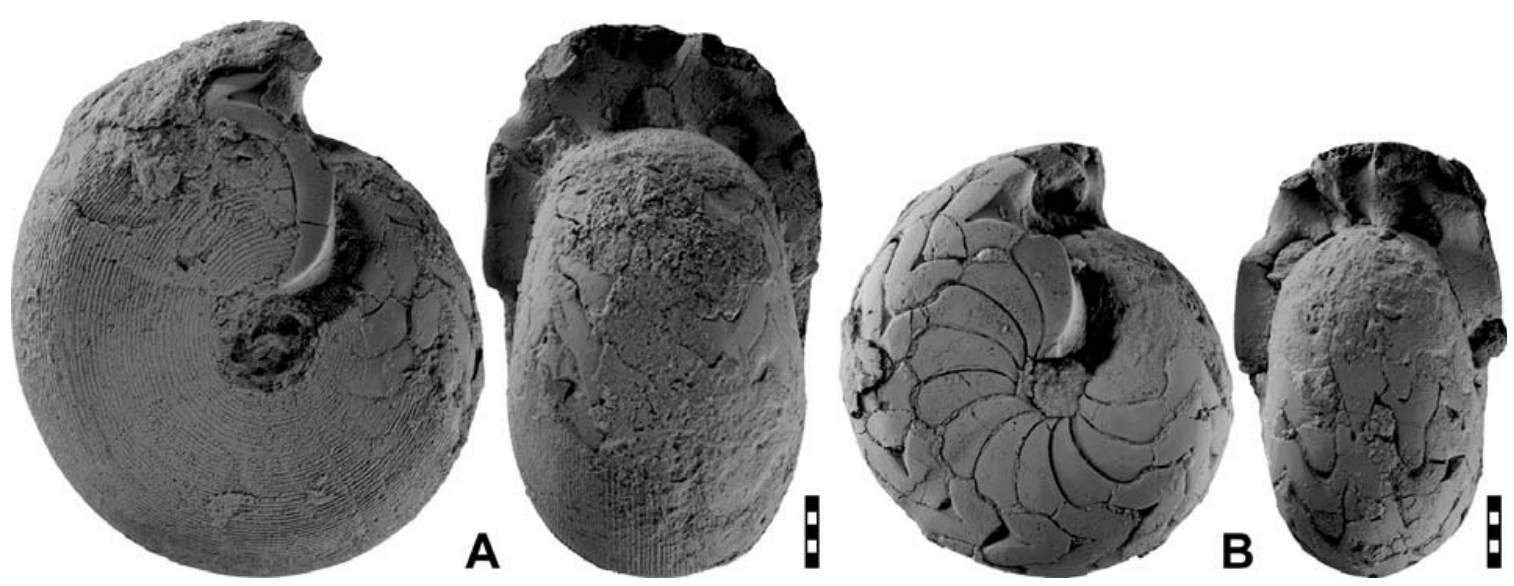

Figure 37. Arnsbergites rufus n. sp. A. Holotype MB.C.13285.1 from Chebket el Hamra; $\times 1.5$. B. Paratype MB.C.13285.2 from Chebket el Hamra; $\times 1.5$. 

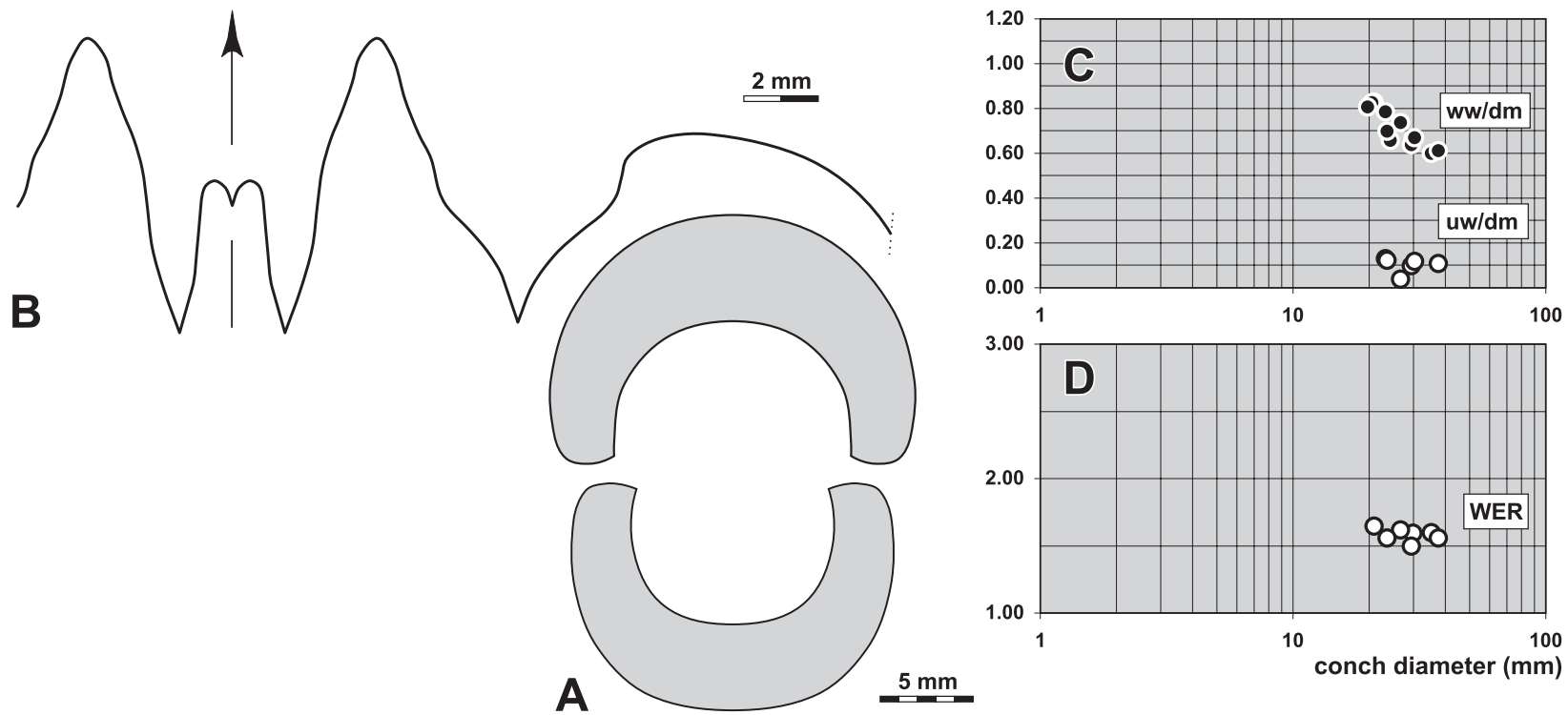

Figure 38. Arnsbergites rufus n. sp. A. Cross section of paratype MB.C.13285.3 from Chebket el Hamra; $\times 2.0$. B. Suture line of paratype MB.C.13285.2 from Chebket el Hamra, at $28.2 \mathrm{~mm} \mathrm{dm}, 18.6 \mathrm{~mm} w w, 6.5 \mathrm{~mm} \mathrm{wh} \times$ ×.0. C, D. Ontogenetic development of the conch width index (ww/dm), umbilical width index (uw/dm) and whorl expansion rate (WER) of all available specimens.

\section{Hibernicoceras Moore \& Hodson, 1958}

Type species. Hibernicoceras hibernicum Moore \& Hodson, 1958.

Discussion. At present, eleven species of Hibernicoceras have been described (AMMON database; Korn \& Ilg 2007). Two of these, H. mucronatum (Knopp, 1931) and H. waldeckense (Haubold, 1933) are based on crushed, poorly preserved material and are very difficult to interpret. Of the remaining species, only $H$. hibernicum Moore \& Hodson, 1958, H. tumidum Moore \& Hodson, 1958, H. striatosphaericum (Brüning, 1923), and H.doliolum Korn, 1988 have been described with respect to their conch ontogeny (Korn 1988, 1997).

The species of Hibernicoceras can be grouped as follows:

A - species with a prominent ventral projection of the growth lines, a ventral sinus is lacking or very shallow at $20 \mathrm{~mm}$ conch diameter; the external lobe has a width of 1.20-1.30 of the adventive lobe:

H. hibernicum Moore \& Hodson, 1958: with a thickly pachyconic conch $(\mathrm{ww} / \mathrm{dm}=0.80$ at $20 \mathrm{~mm} \mathrm{dm}$ ) and coarse growth lines;

H. touissitense $\mathrm{n}$. $\mathrm{sp}$.: with a thinly pachyconic conch $(\mathrm{ww} / \mathrm{dm}=0.63-0.70$ at $20 \mathrm{~mm} \mathrm{dm}$ ) and moderately coarse growth lines;

H. doliolum Korn, 1988: with a thickly pachyconic to globular conch $(\mathrm{ww} / \mathrm{dm}=0.85$ at $20 \mathrm{~mm} \mathrm{dm})$ and fine growth lines.

B - species with a ventral sinus of the growth lines; the external lobe has a width of $1.10-1.30$ of the adventive lobe:

H. striatosphaericum (Brüning, 1923) [= H. posthibernicum Moore \& Hodson, 1958]: with a spindle-shaped juvenile conch, a thinly pachyconic conch at $25 \mathrm{~mm} \mathrm{dm}(\mathrm{ww} / \mathrm{dm}=0.67)$, a comparatively high dorsolateral projection of the growth lines, and a Y-shaped external lobe;

H. tumidum Moore \& Hodson, 1958: with a globular juvenile conch, a thinly pachyconic conch at $25 \mathrm{~mm} \mathrm{dm}(\mathrm{ww} / \mathrm{dm}=0.67)$, a moderate dorsolateral projection of the growth lines, and a rather wide, V-shaped external lobe;

H. mediocris Moore \& Hodson, 1958: juvenile conch not known, with a thinly pachyconic conch at $25 \mathrm{~mm} \mathrm{dm}(\mathrm{ww} / \mathrm{dm}=0.67)$, a low dorsolateral projection of the growth lines, and a rather wide, V-shaped external lobe;

H. ramsbottomi Moore \& Hodson, 1958 [suture line not yet figured]: with a thinly pachyconic conch $(\mathrm{ww} / \mathrm{dm}=0.60-0.65$ at $30 \mathrm{~mm} \mathrm{dm})$ and closely spaced growth lines in larger growth stages;

H. artilobatum n. sp.: with a globular juvenile conch, a pachyconic conch at $25 \mathrm{~mm} \mathrm{dm} \mathrm{(ww/}$ $\mathrm{dm}=0.70$ ), a low dorsolateral projection of the growth lines, and a rather narrow, V-shaped external lobe.

C - species with a ventral sinus of the growth lines; the external lobe has a width of 1.40 of the adventive lobe:

H. carraunense Moore \& Hodson, 1958: with a thinly pachyconic conch $(\mathrm{ww} / \mathrm{dm}=0.65$ at $30 \mathrm{~mm}$ $\mathrm{dm}$ ) and widely spaced growth lines in larger growth stages, ventrolateral saddle rounded;

H. ultimum Korn, 1988: with a thickly pachyconic conch $(\mathrm{ww} / \mathrm{dm}=0.75$ at $20 \mathrm{~mm} \mathrm{dm})$ and moderately spaced growth lines in larger growth stages, ventrolateral saddle subacute; 
H. alentejoense Korn, 1997: with a thinly pachyconic conch $(\mathrm{ww} / \mathrm{dm}=0.70$ at $30 \mathrm{~mm} \mathrm{dm})$ and widely spaced growth lines in larger growth stages, ventrolateral saddle acute.

\section{Hibernicoceras carraunense Moore \& Hodson, 1958} Figures 39-40

1958 Hibernicoceras carraunense Moore \& Hodson, p. 89, pl. 4, fig. 2.

1997 Hibernicoceras carraunense. - Korn, p. 56, textfig. 45.

Holotype. Specimen GSM ZI3845 (Moore Coll.); figured by Moore \& Hodson (1958, pl. 4, fig. 2)

Type locality and horizon. Townland of Carraun, $3 \mathrm{~km}$ south-southwest of Kiltyclogher (Co. Leitrim, Ireland); P1c Subzone (Late Viséan).

Material. 38 limonitic steinkern specimens ranging from 6 and $33 \mathrm{~mm}$ in conch diameter from horizon $\mathrm{CeH}-2$ at localities Chebket el Hamra-E, F, I, and T.

Diagnosis. Hibernicoceras with globular conch at $5 \mathrm{~mm}$ diameter (ww/dm $=0.85-0.95)$, globular conch at $10 \mathrm{~mm}$ diameter (ww/ $\mathrm{dm}=0.85-0.95)$, and thinly pachyconic conch at $30 \mathrm{~mm}$ diameter (ww/dm $=0.65-0.70)$. Umbilicus very wide in early juvenile stage (uw/dm $=0.50$ at $2 \mathrm{~mm} \mathrm{dm}$ ) and becoming continuously narrower throughout ontogeny $(\mathrm{uw} / \mathrm{dm}=0.20-0.30$ at $10 \mathrm{~mm} \mathrm{dm}$, uw/ $\mathrm{dm}=0.10-0.20$ at $20 \mathrm{~mm} \mathrm{dm}$ ); umbilical margin and wall narrowly rounded. Ornamentation with fine, crenulated biconvex and rectiradiate growth-lines with rather high dorsolateral projection and lower ventrolateral projection; ventral sinus very shallow. Spiral lines in a narrow zone around the umbilicus. Suture line with Y-shaped external lobe in juveniles; in the adult stage with V-shaped, moderately wide external lobe $(0.70-0.80$ of the external lobe depth; 1.50 of the adventive lobe width), and moderate median saddle (almost 0.50 of the external lobe depth). Flanks of the external lobe almost straight, ventrolateral saddle narrowly rounded, adventive lobe with slightly sinuous flanks.

Description. Ontogenetic trends of the conch geometry can mainly be seen in the ww/dm ratio and in the uw/ $\mathrm{dm}$ ratio (Fig. 40G). The conch is thickest between 4 and $12 \mathrm{~mm}$ diameter, with a ww/dm ratio ranging from 0.80 to 0.94 . Later stages show a decrease of the relative conch width, and the largest specimens are thinly pachyconic at $33 \mathrm{~mm} \mathrm{dm}(\mathrm{ww} / \mathrm{dm}=0.69)$. The umbilical width index shows a continuous decrease from a value of $0.40-0.45$ to $0.12-0.20$ between 3 and $16 \mathrm{~mm} \mathrm{dm}$. Intraspecific variability is limited and exposed in both characters. A character rather stable during ontogeny is the apertural height; the whorl expansion rate is stable at 1.50 between 2.5 and $24 \mathrm{~mm}$ conch diameter, and only the adult conch shows a slight increase to 1.67 at $33 \mathrm{~mm} \mathrm{dm}$ (Fig. $40 \mathrm{H}$ ).

The two figured cross sections MB.C.13236.1 and MB.C.13236.2, both of specimens with $21 \mathrm{~mm}$ diameter, are very similar and differ only in minor details (Figs 40A, B). They possess the crescent-shaped juvenile whorls, which change into almost U-shaped outer whorls, which are widest at the umbilical margin. The flanks converge towards the rounded venter from the margin. The umbilical opening increases slowly in all stages represented by the specimens.

MB.C.13209.1 is the largest specimen (Fig. 39A); it is fully chambered at almost $33 \mathrm{~mm} \mathrm{dm}$ and does not show any shell remains. The conch is pachyconic (ww/ $\mathrm{dm}=0.71)$ with a narrow umbilicus $(\mathrm{uw} / \mathrm{dm}=0.16)$. It is widest at the narrowly rounded umbilical wall; the flanks converge to the widely rounded venter. The aperture is low, causing a whorl expansion rate of 1.73 . The internal mould possesses three shallow radial constrictions, which extend almost linearly across flanks and venter.

The smaller specimen MB.C.13209.2, reaching nearly $23 \mathrm{~mm} \mathrm{dm} \mathrm{(Fig.} \mathrm{39B),} \mathrm{is} \mathrm{stouter} \mathrm{(ww/}$ $\mathrm{dm}=0.77$ ), but otherwise closely resembles the larger specimen. It shows few shell remains with rather widely spaced, fine and crenulated growth lines. The specimen possesses three shallow radial constrictions.

Shell remains are only occasionally preserved. Specimen MB.C.13275.1 (19 mm dm) possesses fine, closely standing growth lines, which show a dorsolateral projection that is higher than the ventrolateral projection. A very shallow sinus is visible on the venter.

The suture line shows an ontogenetic modification from the condition with Y-shaped external lobe towards a V-shaped form (Figs 40C-E). This transformation takes place at approximately $20 \mathrm{~mm} \mathrm{dm}$, where the
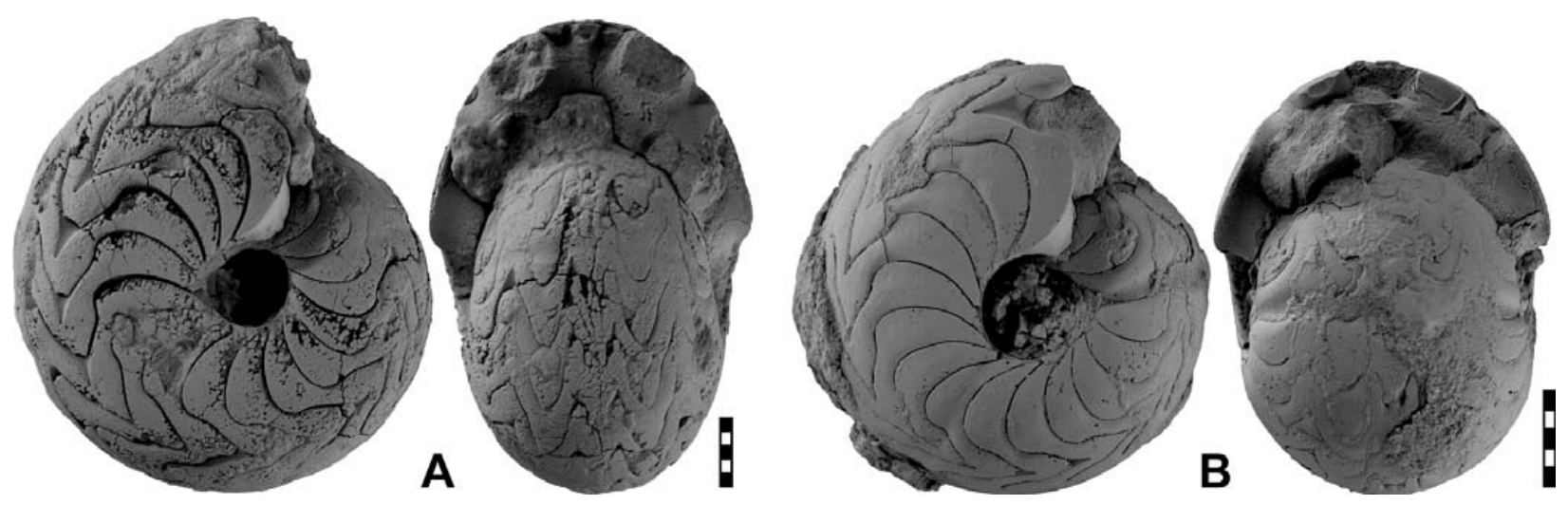

Figure 39. Hibernicoceras carraunense Moore \& Hodson, 1958. A. Specimen MB.C.13209.1 from locality Chebket el Hamra-E; $\times$ 1.5. B. Specimen MB.C.13209.2 from locality Chebket el Hamra-E; $\times 2.0$. 


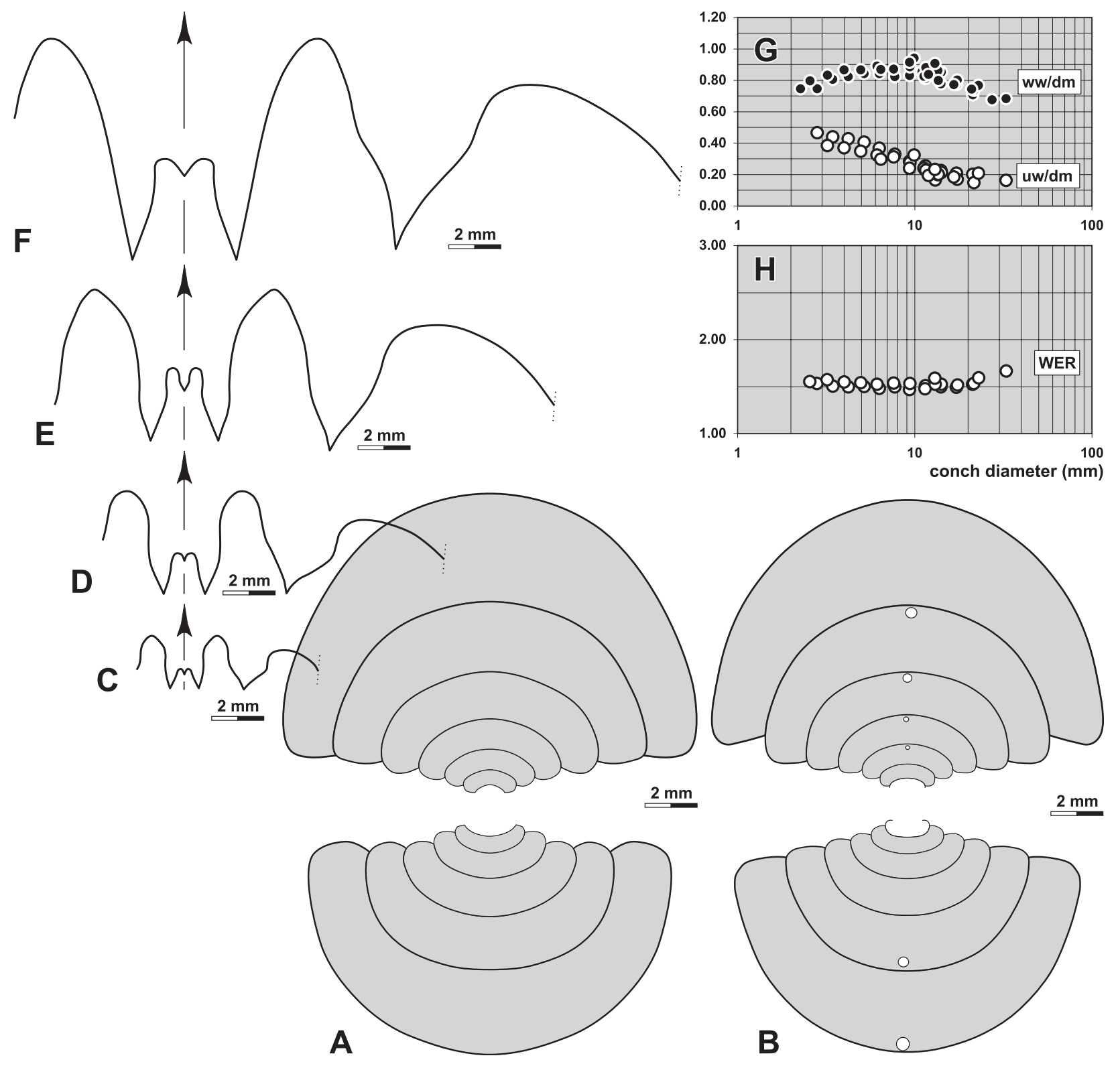

Figure 40. Hibernicoceras carraunense Moore \& Hodson, 1958. A. Cross section of specimen MB.C.13236.1 from locality Chebket el Hamra-I; $\times$ 4.0. B. Cross section of specimen MB.C.13236.2 from locality Chebket el Hamra-I; $\times 4.0$. C. Suture line of specimen MB.C.13236.3 from locality Chebket el Hamra-I, at $8.5 \mathrm{~mm} \mathrm{dm}, 7.4 \mathrm{~mm} w w, 4.2 \mathrm{~mm} w \mathrm{~m} ; \times 4.0$. D. Suture line of specimen MB.C.13236.4 from locality Chebket el Hamra-I, at $16.4 \mathrm{~mm} \mathrm{dm}, 14.1 \mathrm{~mm}$ ww, $7.8 \mathrm{~mm}$ wh; $\times 4.0$. E. Suture line of specimen MB.C.13209.2 from locality Chebket el Hamra-E, at $22.1 \mathrm{~mm} \mathrm{dm}, 17.6 \mathrm{~mm}$ ww, $10.8 \mathrm{~mm}$ wh; $\times 4.0$. F. Suture line of specimen MB.C.13209.1 from locality Chebket el Hamra-E, at $31.3 \mathrm{~mm} \mathrm{dm}, 22.5 \mathrm{~mm}$ ww, $15.3 \mathrm{~mm}$ wh; $\times 4.0$. G, H. Ontogenetic development of the conch width index (ww/dm), umbilical width index (uw/dm) and whorl expansion rate (WER) of all available specimens.

slightly pouched external lobe of the juvenile stage (specimens MB.C. 13236.3 at $8.5 \mathrm{~mm} \mathrm{dm}$; specimen MB.C.13236.4 at $16.6 \mathrm{~mm} \mathrm{dm}$ ) changes into a Vshaped external lobe (such as on specimen MB.C. 13209.2 at $22 \mathrm{~mm} \mathrm{dm}$ ).

The adult suture line (specimen MB.C.13209.1 with $31 \mathrm{~mm} \mathrm{dm}$ ) is characterised by a rather wide external lobe ( 1.40 of the adventive lobe) with almost uncurved flanks (Fig. 40F). The median saddle reaches almost half the external lobe, and the ventrolateral saddle is narrowly rounded. The V-shaped adventive lobe has moderately strongly curved flanks.
Discussion. Attribution to the Irish species is based on close resemblance of conch geometry and the suture line in specimens of $25-30 \mathrm{~mm}$ diameter. However, the Irish species needs to be described in greater detail, particularly with respect to its ontogenetic development to confirm this determination.

Hibernicoceras carraunense has a stouter conch than the co-occurring $H$. touissitense, a wider external lobe, and growth lines with a ventral sinus. The umbilical margin is less pronounced in H. carraunense. H. artilobatum has a lower median saddle and a V-shaped external lobe. 


\section{Hibernicoceras touissitense $\mathbf{n}$. sp.}

Figures $41-42$

Derivation of name. After the town of Touissit, where the material was collected.

Holotype. Specimen MB.C.13292.1 (Ebbighausen \& Weyer 2007 Coll.); illustrated in Figure 41A.

Type locality and horizon. Chebket el Hamra-U (Jerada Basin, NEMorocco); horizon CeH-2, Arnsbergites gracilis Zone or Neoglyphioceras spirale Zone (middle Brigantian, Early Carboniferous).

Material. 67 limonitic steinkern specimens ranging from 7 to $28 \mathrm{~mm}$ in conch diameter from horizon CeH-2 at localities Chebket el Hamra-F, I, T, and an unspecified locality.

Diagnosis. Hibernicoceras with globular conch at $5 \mathrm{~mm}$ diameter $(\mathrm{ww} / \mathrm{dm}=0.85-0.90)$, thickly pachyconic conch at $10 \mathrm{~mm}$ diameter $(\mathrm{ww} / \mathrm{dm}=0.75-0.85)$, and thickly discoidal conch at $30 \mathrm{~mm}$ diameter $(\mathrm{ww} / \mathrm{dm}=0.50-0.60)$. Umbilicus very wide in early juveniles (uw/dm $=0.50$ at $2 \mathrm{~mm} \mathrm{dm}$ ) and narrow to very narrow in all stages larger than $8 \mathrm{~mm} \mathrm{dm}(\mathrm{uw} / \mathrm{dm}=0.10-0.20)$; umbilical margin subangular, umbilical wall rounded. Ornamentation of rather coarse and weakly crenulated, biconvex and rectiradiate growth lines with dorsolateral projection and ventral projection of the same height; external sinus and spiral lines lacking. Suture line with V-shaped, moderately wide external lobe $(0.70$ of the external lobe depth; 1.30 of the adventive lobe width), and moderate median saddle ( 0.50 of the external lobe depth). Flanks of the external lobe slightly sinuous, ventrolateral saddle narrowly rounded, adventive lobe with sinuous flanks.

Description. The ontogeny of the species can be subdivided into three stages. The first $(0.5-2 \mathrm{~mm}$ diameter $)$ is characterised by a narrowing of the conch (ww/ $\mathrm{dm}=0.70$ ) and a widening of the umbilicus (uw/ $\mathrm{dm}=0.50)$. The second $(2-8 \mathrm{~mm} \mathrm{dm})$ likewise is characterised by a widening of the conch $(\mathrm{ww} / \mathrm{dm}=0.85-$ 0.90 ) and the narrowing of the umbilicus (uw/ $\mathrm{dm}=0.15-0.20$ ). In the third (above $8 \mathrm{~mm} \mathrm{dm}$ ), the conch becomes thinner again $(\mathrm{ww} / \mathrm{dm}=0.50-0.55$ at
$30 \mathrm{~mm} \mathrm{dm}$ ), and the umbilical width is stable. The aperture is low in all stages $(\mathrm{WER}=1.50-1.60)$, but there is a slow increase in apertural height in the largest specimens (WER $=1.70$ at $30 \mathrm{~mm} \mathrm{dm}$ ).

The two sectioned paratypes MB.C.13237.2 and MB.C.13237.3, both with about $15 \mathrm{~mm}$ diameter, display the ontogenetic development of the conch geometry from the initial to the preadult stage (Figs 42A-B). Beginning with a crescent-shaped whorl section, later whorls are U-shaped in section with a high rate of whorl overlap.

Paratype MB.C.13237.1 is with $30 \mathrm{~mm} \mathrm{dm}$ the largest of the specimens. It is fully septate and shows a thickly discoidal conch (ww/dm = appr. 0.55).

Smaller specimens, such as the holotype MB.C.13292.1 (18 $\mathrm{mm} \mathrm{dm}$ ) have a stouter conch (ww/ $\mathrm{dm}=0.74)$ with a low aperture $(\mathrm{WER}=1.53)$ and a subangular umbilical margin (Fig. 41A). This specimen possesses remains of the shell; the ornament consists of rather coarse growth lines, which show a dorsolateral projection, a shallow lateral sinus, and a low and wide ventral projection.

The suture line exhibits an ontogenetic development from a near parallel-sided to a V-shaped external lobe (Figs 42C-E). The typical adult suture line is shown in paratype MB.C.13237.1 (Fig. 42F) at almost $30 \mathrm{~mm}$ conch diameter. Smaller specimens of $10-15 \mathrm{~mm}$ diameter show some variability in the shape of the external lobe, which may possess either V-shaped or slightly pouched prongs (such as MB.C.13276.1; Fig. 42D).

Discussion. Hibernicoceras touissitense differs from the co-occurring $H$. carraunense in slightly deviating ontogenetic trajectories of the conch. H. touissitense is more slender in comparable growth stages and the closure of
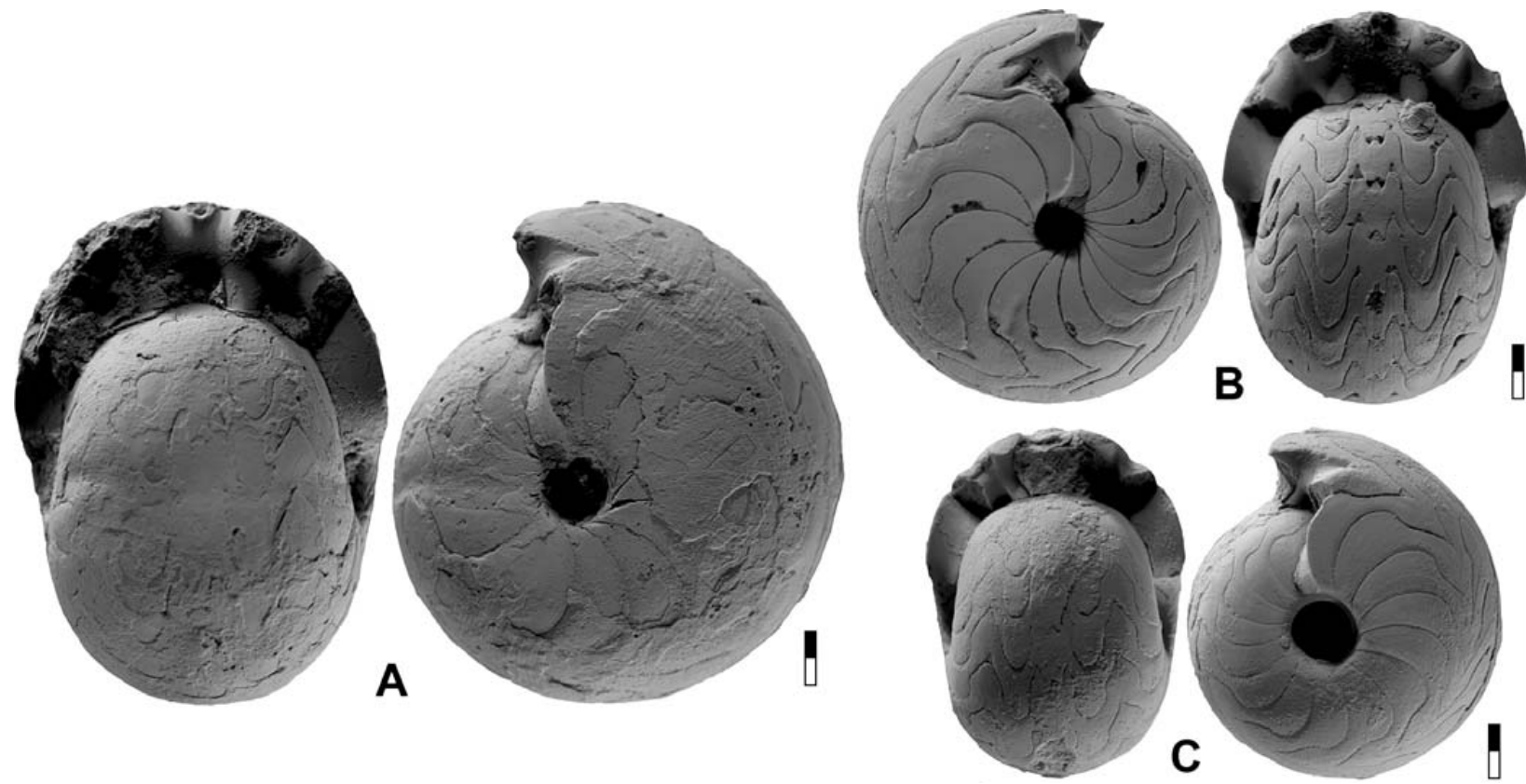

Figure 41. Hibernicoceras touissitense n. sp. A. Holotype MB.C.13292.1 from locality Chebket el Hamra-U; $\times 3.0$. B. Paratype MB.C.13276.1 from locality Chebket el Hamra-T; ×3.0. C. Paratype MB.C.13276.2 from locality Chebket el Hamra-T; $\times 3.0$. 

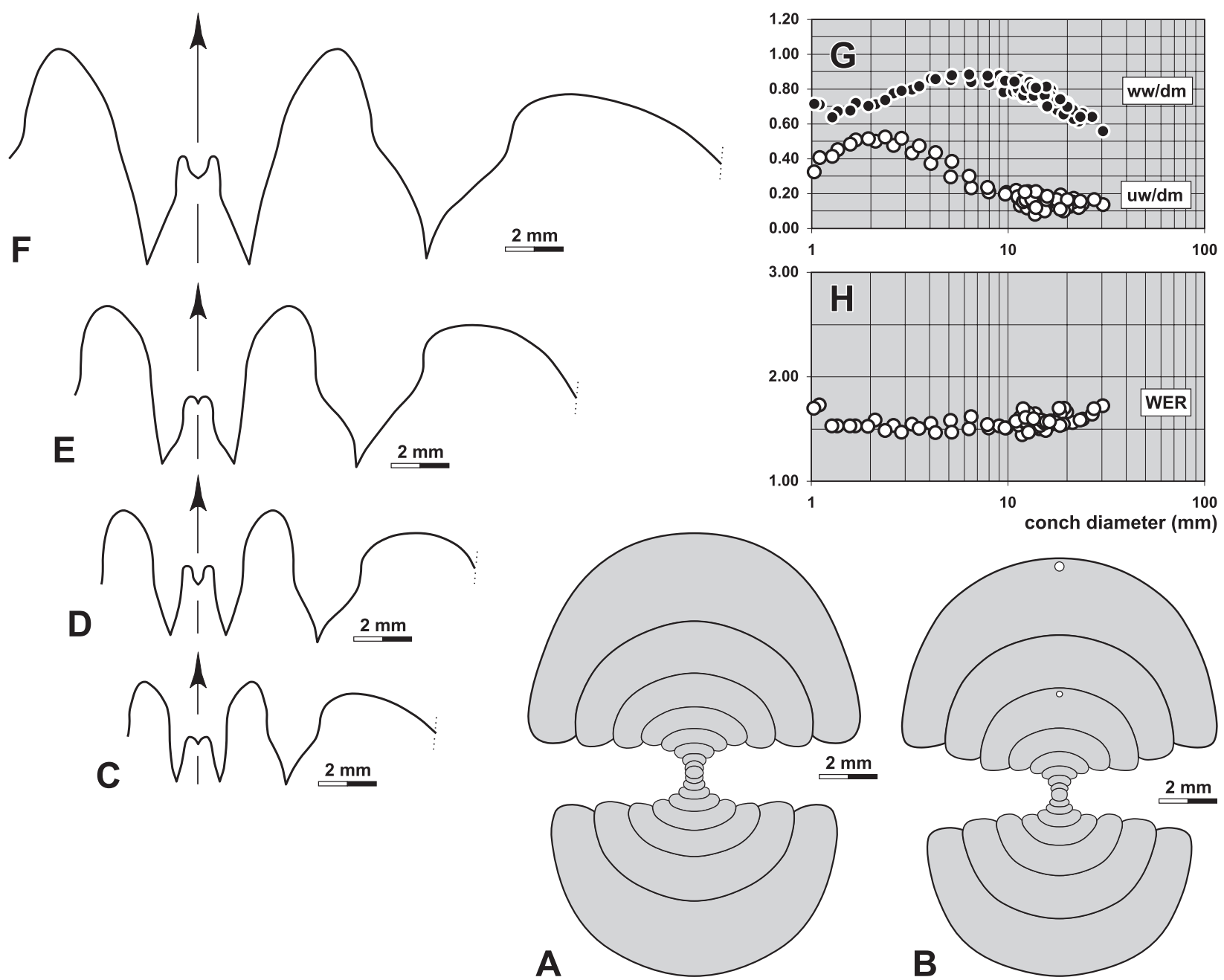

Figure 42. Hibernicoceras touissitense n. sp. A. Cross section of paratype MB.C.13237.2 from locality Chebket el Hamra-I; $\times 4.0$. B. Cross section of paratype MB.C.13237.3 from locality Chebket el Hamra-I; × 4.0. C. Suture line of paratype MB.C.13276.2 from locality Chebket el Hamra-T, at $12.5 \mathrm{~mm} \mathrm{dm}, 9.3 \mathrm{~mm}$ ww, $5.9 \mathrm{~mm}$ wh; $\times 4.0$. D. Suture line of paratype MB.C.13276.1 from locality Chebket el Hamra-T, at $14.1 \mathrm{~mm} \mathrm{dm}, 11.1 \mathrm{~mm} w w, 7.1 \mathrm{~mm}$ wh; $\times 4.0$. E. Suture line of paratype MB.C.13276.3 from locality Chebket el Hamra-T, at $19.7 \mathrm{~mm} \mathrm{dm}, 13.7 \mathrm{~mm}$ ww, $9.9 \mathrm{~mm}$ wh; $\times 4.0$. F. Suture line of paratype MB.C.13237.1 from locality Chebket el Hamra-I, at $29.5 \mathrm{~mm} \mathrm{dm}, 16.2 \mathrm{~mm}$ ww, $14.6 \mathrm{~mm}$ wh; $\times 4.0$. G, H. Ontogenetic development of the conch width index (ww/dm), umbilical width index (uw/dm) and whorl expansion rate (WER) of all available specimens.

the umbilicus is more rapid. H. touissitense has a more pronounced umbilical margin that marks the position where the conch is widest.

In terms of ornament, with the ventral projection of the growth lines (and the absence of a ventral sinus), H. touissitense is similar to H. hibernicum Moore \& Hodson, 1958, but has a more slender conch (ww/ $\mathrm{dm}=0.63-0.70$ in H. touissitense, but 0.79 in H. hibernicum at $21 \mathrm{~mm} \mathrm{dm}$ ).

H. mediocris Moore \& Hodson, 1958 has a similar conch shape and suture line, but possesses very fine growth lines, which form a shallow sinus on the venter.

\section{Hibernicoceras artilobatum n. sp.}

Figures 43-44

Derivation of name. From Latin artis = narrow, because of the narrow external lobe.
Holotype. Specimen MB.C.13286 (Korn \& Ebbighausen 2006 Coll.); illustrated in Figure 43.

Type locality and horizon. Chebket el Hamra (Jerada Basin, NE-Morocco); horizon CeH-2, Arnsbergites gracilis Zone or Neoglyphioceras spirale Zone (middle Brigantian, Early Carboniferous).
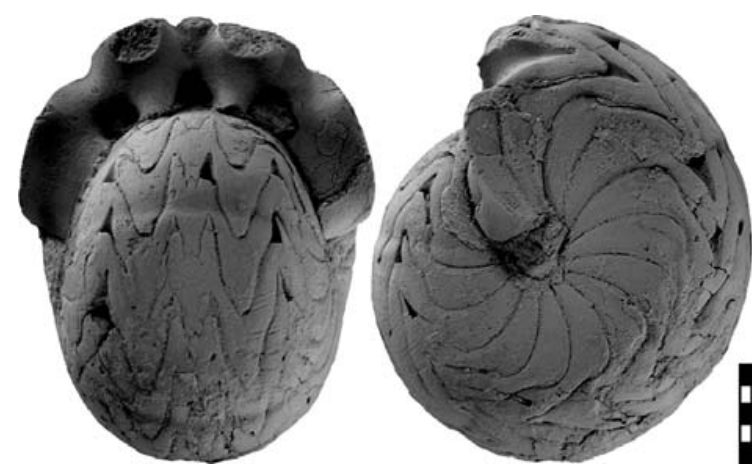

Figure 43. Hibernicoceras artilobatum n. sp. Holotype MB.C.13286 from Chebket el Hamra; $\times 2.0$. 

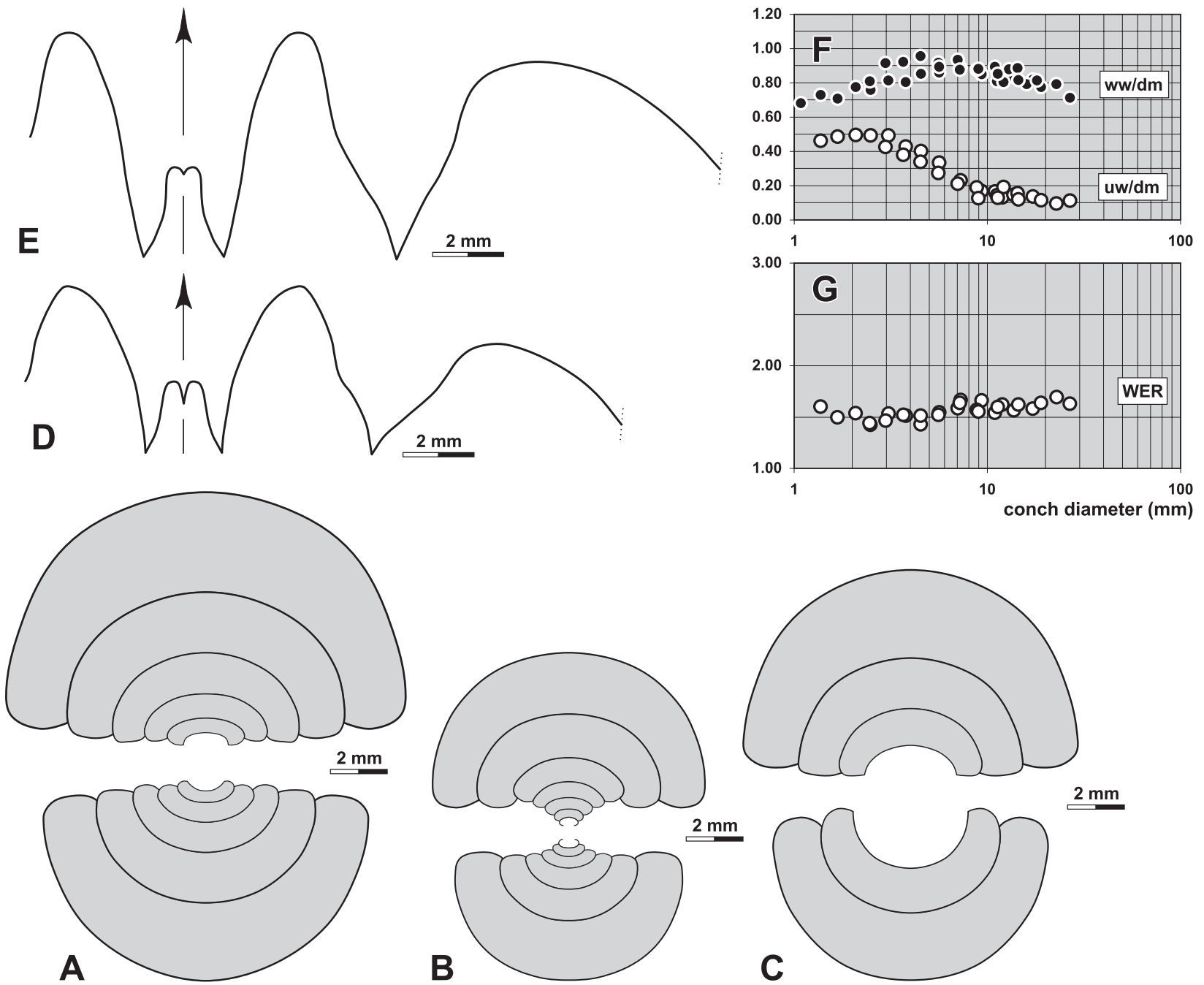

Figure 44. Hibernicoceras artilobatum n. sp. A. Cross section of paratype MB.C.13277.1 from locality Chebket el Hamra-T; $\times 4.0$. B. Cross section of paratype MB.C.13277.2 from locality Chebket el Hamra-T; $\times 4$.0. C. Cross section of paratype MB.C.13238.1 from locality Chebket el Hamra-I; $\times 4.0$. D. Suture line of paratype MB.C.13238.2 from locality Chebket el Hamra-I, at $18.3 \mathrm{~mm}$ $\mathrm{dm}, 15.3 \mathrm{~mm}$ ww, $9.5 \mathrm{~mm}$ wh; $\times 5.0$. E. Suture line of holotype MB.C.13286 from Chebket el Hamra, at $22.0 \mathrm{~mm} \mathrm{dm}, 17.2 \mathrm{~mm}$ ww, $11.6 \mathrm{~mm}$ wh; $\times 5.0$. F, G. Ontogenetic development of the conch width index (ww/dm), umbilical width index (uw/dm) and whorl expansion rate (WER) of all available specimens.

Material. 13 limonitic steinkern specimens varying from 10 to $27 \mathrm{~mm}$ in conch diameter from horizon $\mathrm{CeH}-2$ at localities Chebket el Hamra-F, I, T, and an unspecified locality.

Diagnosis. Hibernicoceras with globular conch at $5 \mathrm{~mm}$ diameter (ww/dm $=0.85-0.95)$, thickly pachyconic to globular conch at $10 \mathrm{~mm}$ diameter $(\mathrm{ww} / \mathrm{dm}=0.80-0.90)$, and thickly pachyconic conch at $20 \mathrm{~mm}$ diameter $(\mathrm{ww} / \mathrm{dm}=0.75-0.80)$. Umbilicus very wide in early juveniles (uw/dm $=0.50$ at $2 \mathrm{~mm} \mathrm{dm}$ ) and becoming continuously narrower throughout ontogeny (uw/ $/ \mathrm{dm}=0.12-0.16$ at $10 \mathrm{~mm}$ $\mathrm{dm}, u w / \mathrm{dm}=0.10-0.15$ at $20 \mathrm{~mm} \mathrm{dm}$ ); umbilical margin and wall rounded. Ornamentation with rather coarse, crenulated biconvex and rectiradiate growth-lines having rather high dorsolateral projection and lower ventrolateral projection; ventral sinus very shallow. Spiral lines in a narrow zone around the umbilicus. Suture line with Vshaped external lobe in juveniles; in the adult stage with V-shaped, narrow external lobe ( 0.55 of the external lobe depth; 1.10 of the adventive lobe width), and moderate median saddle (almost 0.40 of the external lobe depth). Flanks of the external lobe almost straight, ventrolateral saddle narrowly rounded, adventive lobe with slightly sinuous flanks.
Description. The species shows ontogenetic changes only in the ww/dm and the uw/dm ratios (Fig. 44F). Two phases of ontogeny can be distinguished. A first phase ranges up to about $9 \mathrm{~mm}$ conch diameter; this phase is characterised by a slow increase of the whorl width up $0.90-0.95$ and a reduction of the uw/dm ratio from 0.50 in early juveniles to $0.10-0.20$. The second phase shows a development towards a more slender conch $(w w / d m=0.70$ at $27 \mathrm{~mm} \mathrm{dm})$ and an umbilicus that remains narrow (uw/dm $=0.10$ at $15-27 \mathrm{~mm} \mathrm{dm}$ ). The aperture is low in all growth stages, with a WER very slowly increasing from 1.50 in early juveniles to $1.65-1.70$ at $20-27 \mathrm{~mm} \mathrm{dm}$ (Fig. 44G).

Holotype MB.C.13286 is the largest individual having a diameter of nearly $23 \mathrm{~mm}$ (Fig. 43). It is thickly pachyconic $(\mathrm{ww} / \mathrm{dm}=0.79)$ with a narrow umbilicus (uw/dm $=0.10)$ and a low aperture $(\mathrm{WER}=1.69)$. Flanks, venter, and umbilical margin are broadly 
rounded. Some remains of the shell are visible; they show rather coarse growth lines, which extend with biconvex course and form a wide and shallow ventral sinus. The steinkern has five shallow, almost linear constrictions.

A similar conch geometry can be seen in specimen MB.C.13238.2 with $19 \mathrm{~mm} \mathrm{dm}$. It possesses shell remains that show fine and crenulated growth lines and a few spiral lines around the umbilicus.

The suture line of specimen MB.C.13286 (22 mm $\mathrm{dm})$ differs from the suture lines of other species of $\mathrm{Hi}$ bernicoceras (Fig. 44E). Its external lobe is V-shaped with almost straight flanks, and the median saddle reaches only $40 \%$ of the depth of the E lobe. The E lobe is only little wider (1.10) than the adventive lobe, and the ventrolateral saddle is narrowly rounded.

A V-shaped external lobe with strongly diverging flanks is seen in the smaller specimen MB.C.13238.2 (18 mm dm; Fig. 44D). The median saddle has 0.40 of the E lobe depth, and the ventrolateral saddle is asymmetric with a blunt top. The adventive lobe is V-shaped with a stronger sinuous ventral flank.

Discussion. Hibernicoceras artilobatum differs from the other two species of the genus found at Chebket el Hamra in having a suture line that possesses a V-shaped external lobe in the intermediate growth stage. Additionally, the external lobe is much narrower and the median saddle is lower in H. artilobatum ( 0.40 of the $\mathrm{E}$ lobe depth). In these two respects, the new species differs from all other representatives of Hibernicoceras.

\section{Paraglyphioceras Brüning, 1923}

Type species. Paraglyphioceras rotundum Brüning, 1923.

Discussion. At present, 15 possible valid species of Paraglyphioceras have been described (AMMON database; Korn \& Ilg 2007). However, a number of these species, i.e. P. densiplicatum (Kumpera, 1971), P. dorsoplanum (Brüning, 1923), P. elegans (Bisat, 1928), P. kajlovecense (Patteisky, 1930), P. myrtilense (Feio, 1946), P. pseudostriatum (Bisat, 1924), P. reticulatum (Bisat, 1924), and P. semistriatum (Nicolaus, 1963) are based on crushed or otherwise poorly preserved material and are very difficult to interpret and determine. Of the remaining species, only $P$. radiatum Hodson \& Moore, 1959, P. rudis (Moore \& Hodson, 1958), P. rotundum (Brüning, 1923), and P. castor Korn, 1988 have been described with respect to their conch ontogeny (Korn 1988, 1990b).

The species of Paraglyphioceras can be grouped as follows:

A - species with a narrow external lobe (1.20 of the adventive lobe) and a weak ornament:

P. castor Korn, 1988: with a low aperture (WER $=1.55$ at $30 \mathrm{~mm} \mathrm{dm}$ ) and spiral lines around the narrow umbilicus;
P. bisati (Moore, 1936): with spiral lines around the narrow umbilicus and on the venter;

P. guadianense Korn, 1997: with spiral lines around the rather wide umbilicus and on the venter;

P. celeris n. sp.: with a moderately high aperture $(\mathrm{WER}=1.90-2.20$ in stages larger than $10 \mathrm{~mm}$ $\mathrm{dm})$.

B - species with a narrow external lobe (1.20 of the adventive lobe) and a coarse falcate ornament:

P. radiatum Hodson \& Moore, 1959.

C - species with a wide external lobe (1.40 of the adventive lobe or more):

P. striatum (Sowerby, 1814): with a well-rounded ventrolateral saddle and a pouched adventive lobe;

P. rudis (Moore \& Hodson, 1958): with a thickly discoidal to thinly pachyconic conch at $15 \mathrm{~mm}$ diameter $(\mathrm{ww} / \mathrm{dm}=0.55-0.65)$, a narrowly rounded ventrolateral saddle, and a simple V-shaped adventive lobe;

P. rotundum (Brüning, 1923): with a thickly pachyconic conch at $15 \mathrm{~mm}$ diameter $(\mathrm{ww} / \mathrm{dm}=0.75)$, a subacute ventrolateral saddle, and a simple Vshaped adventive lobe.

\section{Paraglyphioceras rudis (Moore \& Hodson, 1958) Figures 45-46}

Holotype. Specimen GSM ZI4083 (Moore Coll.); figured by Moore \& Hodson (1958, pl. 9, fig. 2).

Type locality and horizon. Townland of Carraun, $3 \mathrm{~km}$ south-west of Kiltyclogher (Co. Leitrim, Ireland); P1c Subzone, approximately $10 \mathrm{~m}$ above the highest occurrence of Arnsbergites sphaericostriatus (middle Brigantian, Late Viséan).

Material. 102 limonitic steinkern specimens from 8 and $38 \mathrm{~mm}$ in conch diameter, from horizon $\mathrm{CeH}-2$ at localities Chebket el HamraF, I, T, and an unspecified locality.

Diagnosis. Paraglyphioceras with thickly pachyconic to globular conch at $5 \mathrm{~mm}$ diameter $(\mathrm{ww} / \mathrm{dm}=0.80-0.90)$, thickly pachyconic conch at $10 \mathrm{~mm}$ diameter $(\mathrm{ww} / \mathrm{dm}=0.75-0.85)$, and thickly discoidal to thinly pachyconic conch at $25 \mathrm{~mm}$ diameter $(\mathrm{ww} / \mathrm{dm}=0.55-$ 0.65 ). Umbilicus wide in early juveniles (uw $/ \mathrm{dm}=0.40$ at $2 \mathrm{~mm} \mathrm{dm}$ ) and narrow to very narrow in all stages larger than $8 \mathrm{~mm} \mathrm{dm}$ (uw/ $\mathrm{dm}=0.05-0.12$ ); umbilical margin and umbilical wall rounded. Aperture moderately high, WER $=1.70-1.80$ in stages larger than $10 \mathrm{~mm} \mathrm{dm}$. Ornamentation with strongly crenulated bicovex and rectiradiate growth-lines; fine spiral lines on flanks and venter. Suture line with V-shaped, moderately wide external lobe $(0.70$ of the external lobe depth; 1.50 of the adventive lobe width), and moderate median saddle (almost 0.50 of the external lobe depth). Flanks of the Vshaped external lobe slightly sinuous, ventrolateral saddle subacute, adventive lobe with slightly sinuous flanks.

Description. The morphometric plots show that intraspecific variability is rather limited in this species (Figs 46H, I). Ontogenetic changes can, however, clearly be seen in the three cardinal conch parameters. The short juvenile stage with a wide umbilicus (uw/ $\mathrm{dm}=0.40-0.45$ at $2-3 \mathrm{~mm} \mathrm{dm}$ ) is replaced by a stage with thickly pachyconic to globular conch (ww/ 

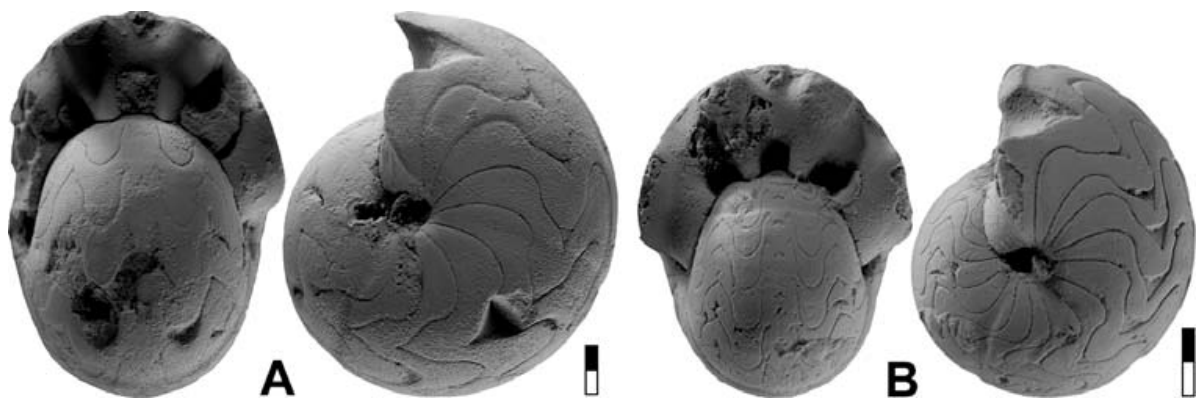

Figure 45. Paraglyphioceras rudis (Moore \& Hodson, 1958). A. Specimen MB.C.13278.1 from locality Chebket el Hamra-T; $\times 2.5$. B. Specimen MB.C.13278.2 from locality Chebket el Hamra-T; $\times 3.5$.
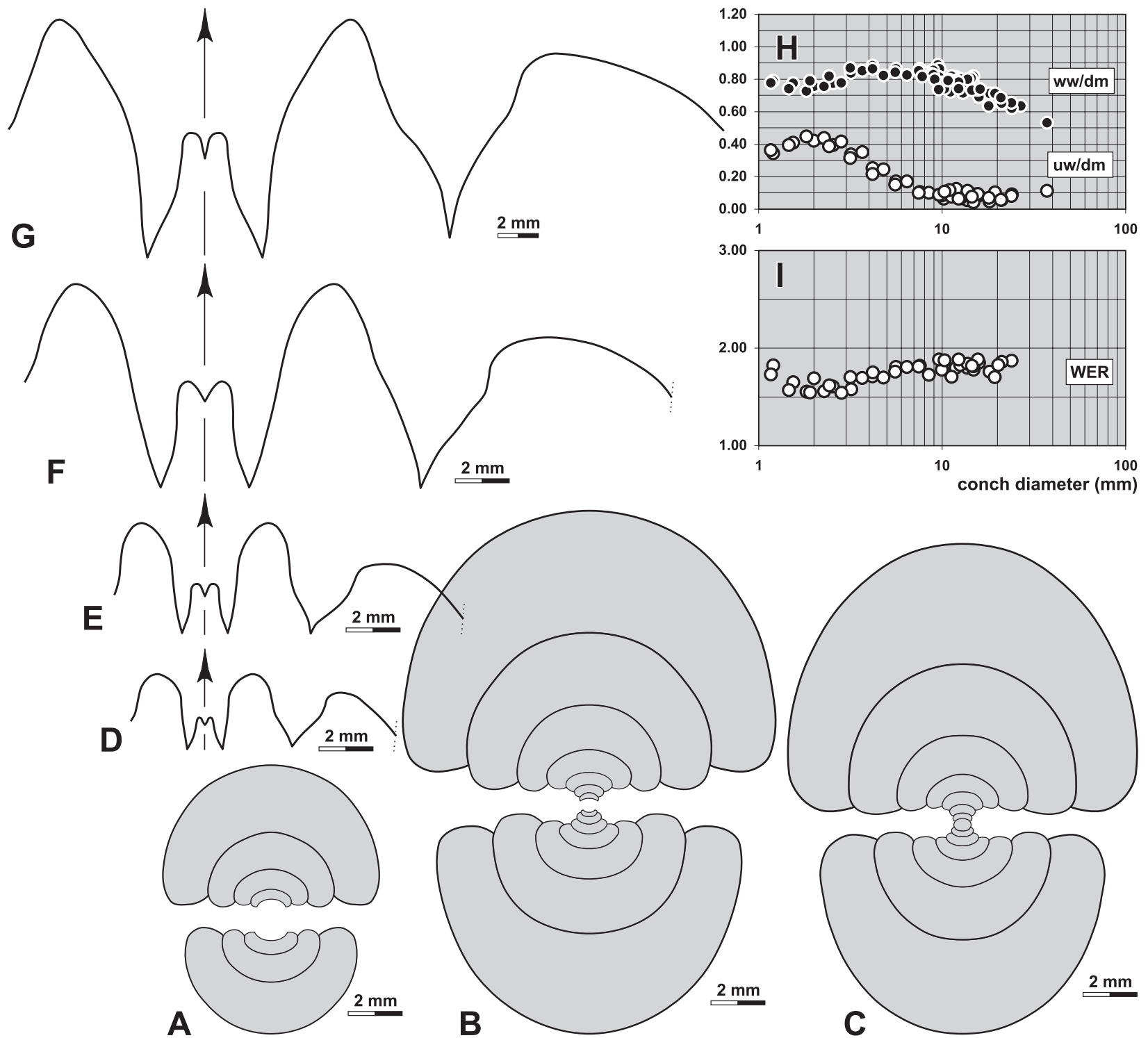

Figure 46. Paraglyphioceras rudis (Moore \& Hodson, 1958). A. Cross section of specimen MB.C.13278.3 from locality Chebket el Hamra-T; $\times 4.0$. B. Cross section of specimen MB.C.13223.1 from locality Chebket el Hamra-F; $\times 4.0$. C. Cross section of specimen MB.C.13239.1 from locality Chebket el Hamra-I; $\times$ 4.0. D. Suture line of specimen MB.C.13278.2 from locality Chebket el Hamra-T, at $9.2 \mathrm{~mm} \mathrm{dm}, 7.7 \mathrm{~mm}$ ww, $5.1 \mathrm{~mm}$ wh; $\times 4.0$. E. Suture line of specimen MB.C.13278.1 from locality Chebket el Hamra-T, at $14.0 \mathrm{~mm} \mathrm{dm}, 10.5 \mathrm{~mm}$ ww, $7.6 \mathrm{~mm}$ wh; $\times 4.0$. F. Suture line of specimen MB.C.13278.4 from locality Chebket el Hamra-T, at $16.7 \mathrm{~mm}$ ww, $14.8 \mathrm{~mm}$ wh; $\times 4.0$. G. Suture line of specimen MB.C.13278.5 from locality Chebket el Hamra-T, at $21.0 \mathrm{~mm}$ wh; $\times 3.0$. H, I. Ontogenetic development of the conch width index (ww/dm), umbilical width index (uw/dm) and whorl expansion rate (WER) of all available specimens. 
$\mathrm{dm}=0.80-0.90)$ and closure of the umbilicus between 3 and $9 \mathrm{~mm} \mathrm{dm}$. Later in ontogeny, the conch becomes more slender $(\mathrm{ww} / \mathrm{dm}=0.60-0.65$ at $25 \mathrm{~mm}$ $\mathrm{dm}$ ) and the umbilicus remains very narrow (uw/ $\mathrm{dm}=0.05-0.10)$. The aperture is low in early juveniles (WER $=1.55-1.70$ at $2-4 \mathrm{~mm} \mathrm{dm}$ ) and becomes slightly higher during ontogeny $(\mathrm{WER}=1.70-1.90$ between 10 and $25 \mathrm{~mm} \mathrm{dm}$ ).

The cross sections MB.C.13278.3, MB.C.13223.1, and MB.C.13239.1, display the characteristic conch development of the species (Figs 46A-C). The inner whorls are crescent-shaped and embrace the preceding to a small degree. From $2 \mathrm{~mm}$ conch diameter onward, there is a rather stable umbilical opening of approximately $1 \mathrm{~mm}$, resulting in a continuously decreasing uw/dm ratio. The whorls become rapidly wider and more embracing. The conch then becomes narrowly umbilicate with broadly rounded flanks and venter, and rounded umbilical wall at $10 \mathrm{~mm}$ diameter.

Unfortunately all large specimens are fragmentary. The largest consists of a phragmocone measuring about $50 \mathrm{~mm}$. It possesses few remains of the shell around the umbilicus; there are delicate spiral lines and fine backwardly directed growth lines.

Specimen MB.C.13278.1 is an immature individual of $15.5 \mathrm{~mm}$ diameter (Fig. 45A) and is thickly pachyconic $(\mathrm{ww} / \mathrm{dm}=0.74)$ with very narrow umbilicus (uw/ $\mathrm{dm}=0.09)$. It has broadly rounded flanks and venter and a rounded umbilical wall. The steinkern is smooth except for some very weak linear constrictions. Some ornament is preserved; it consists of very fine, almost linear growth lines. The fragmentary specimen MB.C.13278.6 contains the impression of shell ornament in the dorsal portion; at about a diameter of $20 \mathrm{~mm}$ fine spirals on flanks and venter, and biconvex, strongly crenulated growth lines appear.

The juvenile specimen MB.C.13278.2 is, at $9.5 \mathrm{~mm}$ diameter, similar in its conch geometry (Fig. 45B). It has four steinkern constrictions, which extend in a near-linear manner with a shallow ventral sinus.

The adult suture line, drawn from specimen MB.C.13278.5 (21 mm whorl height), as in most of the goniatitoid species, has a Y-shaped external lobe, which has a median saddle reaching about half height of the E lobe (Fig. 46G). The ventrolateral saddle is subacute and the adventive lobe is V-shaped with curved flanks; it is asymmetric with a slightly curved ventral flank and a stronger curved dorsal flank.

Smaller specimens, such as specimen MB.C.13278.4 (16.5 $\mathrm{mm} \mathrm{ww})$ possess a V-shaped external lobe and a narrowly rounded ventrolateral saddle (Fig. 46F). The median saddle reaches half the height of the external lobe. Juvenile specimens, such as MB.C.13278.1 $(14 \mathrm{~mm} \mathrm{dm})$ and MB.C.13278.2 (9 mm dm) show a more rounded ventrolateral saddle (Figs 46D, E), but have an adventive lobe similar to the larger specimens.

Discussion. Paraglyphioceras rudis and P. celeris possess similar conchs in terms of the ww/dm and uw/dm ratios, but they differ significantly in the ontogenetic development of the apertural height. In specimens between 10 and $25 \mathrm{~mm} \mathrm{dm}$, the whorl expansion rate reaches only 1.90 in $P$. rudis, but 2.20 in P. celeris. The suture line shows further differences, with $P$. celeris possessing a wider external lobe. P. rotundum is similar in the $\mathrm{E}$ lobe width, but has a stouter conch and a wider umbilicus.

\section{Paraglyphioceras celeris n. sp. \\ Figures 47-48}

Derivation of name. From Latin celeris = quick, because of the rapidly increasing apertural height.

Holotype. Specimen MB.C.13279.1 (Ebbighausen \& Weyer 2007 Coll.); illustrated in Figure 47A.

Type locality and horizon. Chebket el Hamra-T (Jerada Basin, NEMorocco); horizon CeH-2, Arnsbergites gracilis Zone or Neoglyphioceras spirale Zone (middle Brigantian, Late Viséan).

Material. 18 limonitic steinkern specimens between 7 and $28 \mathrm{~mm}$ conch diameter from horizon $\mathrm{CeH}-2$ at localities Chebket el Hamra-F, $\mathrm{I}$, and $\mathrm{T}$.

Diagnosis. Paraglyphioceras with globular conch at $5 \mathrm{~mm}$ diameter $(\mathrm{ww} / \mathrm{dm}=0.85-0.90)$, thickly pachyconic conch at $10 \mathrm{~mm}$ diameter $(\mathrm{ww} / \mathrm{dm}=0.80-0.85)$, and thinly pachyconic conch at $15 \mathrm{~mm} \mathrm{diam-}$ eter $(\mathrm{ww} / \mathrm{dm}=0.65-0.75)$. Umbilicus wide in early juveniles (uw/ $\mathrm{dm}=0.40$ at $2 \mathrm{~mm} \mathrm{dm}$ ) and narrow to very narrow in all stages larger than $8 \mathrm{~mm} \mathrm{dm}$ (uw/dm $=0.05-0.10)$; umbilical margin and umbilical wall rounded. Aperture moderately high, WER increases rapidly to $1.90-2.20$ in stages larger than $10 \mathrm{~mm} \mathrm{dm}$. Ornamentation with crenulated biconvex and rectiradiate growth-lines having low dorsolateral projection and higher ventrolateral projection; external sinus deep; spiral lines lacking. Suture line with V-shaped, moderately wide external lobe ( 0.65 of the external lobe depth; 1.10 of the adventive lobe width), and with moderate median saddle (almost 0.50 of the external lobe depth). Flanks of the V-shaped and later Y-shaped external lobe slightly incurved, ventrolateral saddle subacute, adventive lobe with strongly sinuous dorsal flank.

Description. Ontogenetic changes are mainly visible in the umbilical width and the apertural height, whereas the ww/dm ratio shows only minor changes (Figs $48 \mathrm{E}$, F). After the evolute juvenile stage (uw $/ \mathrm{dm}=0.40$ at $2-3 \mathrm{~mm} \mathrm{dm}$ ) a rapid reduction of the relative umbilical width towards less than 0.10 at $9 \mathrm{~mm} \mathrm{dm}$ follows. At the same time, the apertural height increases from $1.50-1.65$ in juvenile stages to $1.90-2.20$ in stages larger than $10 \mathrm{~mm} \mathrm{dm}$.

The two cross sections MB.C.13279.4 and MB.C.13279.5, both of specimens between about 15 and $16.5 \mathrm{~mm}$ diameter, are similar and show well the ontogenetic changes of the species (Figs 48A, B). The widely umbilicate juvenile stage that is replaced by a pachyconic stage with a stagnating absolute opening of the umbilicus, (and therefore a continuous lowering of the uw/dm ratio), may be seen, accompanied by an increase in height of the aperture.

The incomplete paratype MB.C.13279.6 has $22.5 \mathrm{~mm}$ diameter and belongs to the largest individuals. It is thinly pachyconic with a very narrow umbilicus and a high aperture $(\mathrm{WER}=2.17)$. Weak constrictions are 

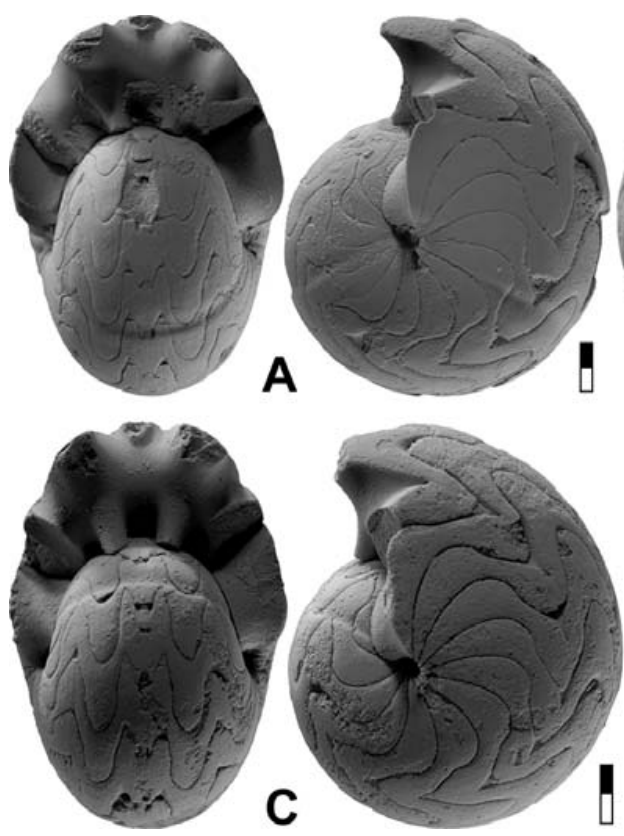
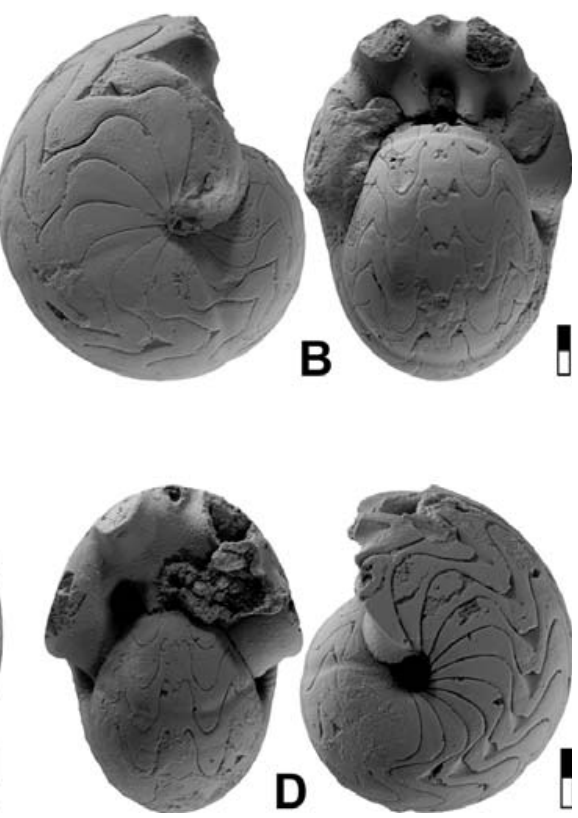

Figure 47. Paraglyphioceras celeris n. sp. A. Holotype MB.C.13279.1 from locality Chebket el Hamra-T; $\times 2.5$. B. Paratype MB.C.13279.2 from locality Chebket el Hamra-T; $\times 2.5$. C. Paratype MB.C.13279.3 from locality Chebket el Hamra-T; $\times 3.0$. D. Paratype MB.C.13224.1 from locality Chebket el Hamra-F; $\times 3.0$.

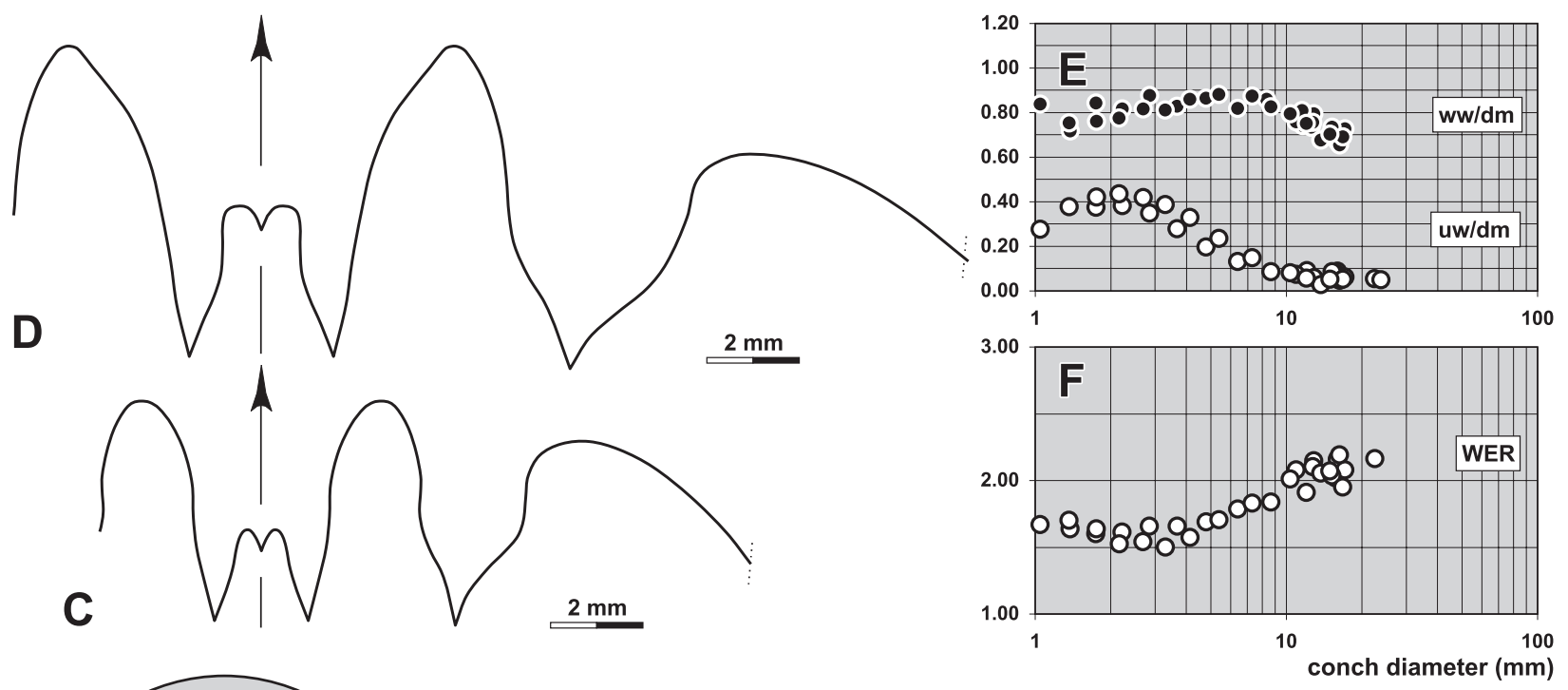

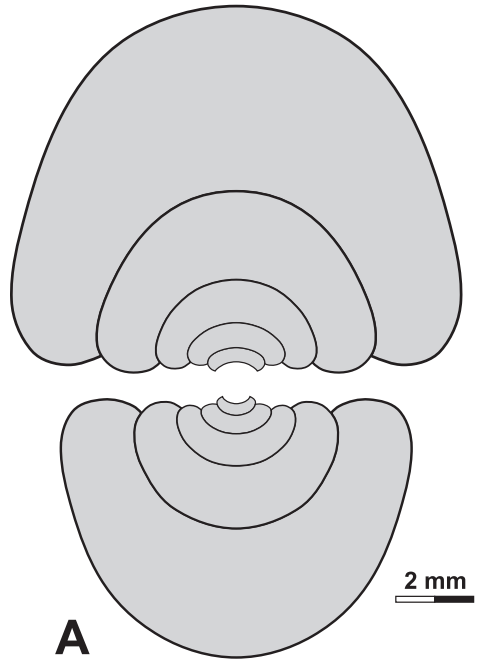

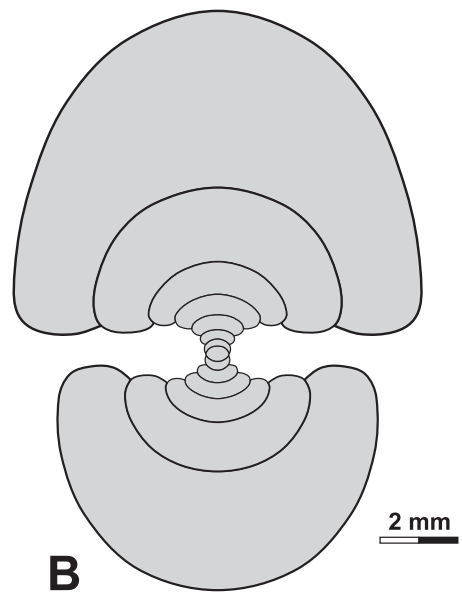

Figure 48. Paraglyphioceras celeris n. sp. A. Cross section of paratype MB.C.13279.4 from locality Chebket el Hamra-T; $\times 4.0$. B. Cross section of paratype MB.C.13279.5 from locality Chebket el Hamra-T; $\times 4.0$. C. Suture line of paratype MB.C.13279.2 from locality Chebket el Hamra-T, at $14.7 \mathrm{~mm} \mathrm{dm}, 11.1 \mathrm{~mm}$ ww, $7.8 \mathrm{~mm}$ wh; $\times 5.0$. D. Suture line of paratype MB.C.13279.6 from locality Chebket el Hamra-T, at $21.3 \mathrm{~mm} \mathrm{dm}$, $12.8 \mathrm{~mm}$ wh; $\times 5.0$. E, F. Ontogenetic development of the conch width index (ww/dm), umbilical width index (uw/dm) and whorl expansion rate (WER) of all available specimens. 
visible on the internal mould; these run almost straight across the flanks and then bend back to form a shallow ventral sinus.

Holotype MB.C.13279.1 shows the morphology of the intermediate growth stage (Fig. 47A). It has a conch diameter of about $15.5 \mathrm{~mm}$ and is thinly pachyconic (ww/ $\mathrm{dm}=0.72$ ) with a very narrow umbilicus (uw/ $\mathrm{dm}=0.08)$ and a rather high aperture (WER $=2.02)$. Flanks and venter are broadly rounded. It is a fully septate internal mould showing weak radial constrictions standing $90-120^{\circ}$ apart; these extend almost linearly across the flanks and venter but form a shallow ventral sinus.

Paratype MB.C.13279.2 (15.2 $\mathrm{mm} \mathrm{dm})$ is very similar in its conch ratios. It also possesses irregularly arranged steinkern constrictions, but here these are curved with a shallow lateral sinus and a more pronounced ventral sinus (Fig. 47B).

The suture line of paratype MB.C.13279.6 (drawn at $21 \mathrm{~mm} \mathrm{dm}$ ) shows the Y-shaped external lobe, which has almost straight flanks in the lower three quarters (Fig. 48D). A median saddle is raised up to almost half the depth of the E lobe and produces two slightly asymmetric, narrow prongs of the E lobe. The subacute and rather narrow ventrolateral saddle is asymmetric with a blunt top. The asymmetric adventive lobe has a much stronger curved dorsal flank.

Smaller stages differ significantly in the suture line. Specimen MB.C.13279.2 (14.7 $\mathrm{mm} \mathrm{dm}$ ) has an external lobe with stronger sinuous flanks, a lower median saddle, a very narrow and narrowly rounded ventrolateral saddle, and an almost lanceolate, pouched adventive lobe (Fig. 48C).

Discussion. For a comparison with the co-occurring $P$. rudis, see discussion under that species. $P$. celeris differs from the species P. castor and P. bisati in its wider external lobe.

\section{Lusitanoceras Pereira de Sousa, 1923}

Type species. Lusitanoceras algarviense Pereira de Sousa, 1923.

Discussion. Thirteen possibly valid species of Lusitanoceras are currently known (AMMON database; Korn \& Ilg 2007). The genus is widely distributed from the western United States across North Africa, Iberia, Northwest and Central Europe to the South Urals, Novaya Zemlya, Northwest China, and Mongolia. Only some of the species have been described with respect to their complete morphological inventory.

The European species of Lusitanoceras can be grouped as follows:

A - species with falcate ornament in the adult stage:

L. algarviense Pereira de Sousa, 1923: with weak spiral ornament (120-150 spiral lines at $30 \mathrm{~mm}$ conch diameter);

L. zirari n. sp.: with coarse spiral ornament (approximately 80-90 spiral lines at $30 \mathrm{~mm}$ conch diameter).
B - species without falcate ornament in the adult stage:

L. poststriatum (Brüning, 1923): with weak spiral ornament (approximately 120 spiral lines at $30 \mathrm{~mm}$ conch diameter);

L. granosum (Portlock, 1843): with coarse spiral ornament (approximately 80 spiral lines).

\section{Lusitanoceras zirari n. sp.}

Figures 49-50

Derivation of name. After Yahia Zirar (Touissit), for his assistance in the field.

Holotype. Specimen MB.C.13296 (Ebbighausen \& Weyer 2007 Coll.); illustrated in Figure 49C.

Type locality and horizon. Chebket el Hamra (Jerada Basin, NE-Morocco); horizon $\mathrm{CeH}-5$, probably Lusitanoceras poststriatum Zone (late Brigantian, Early Carboniferous).

Material. 58 limonitic and phosphatic specimens ranging in diameter from 12 and $71 \mathrm{~mm}$ from horizon $\mathrm{CeH}-5$ at localities Chebket el Hamra-K, L, O, P, and an unspecified locality.

Diagnosis. Lusitanoceras with thickly pachyconic to globular conch at $10 \mathrm{~mm}$ diameter $(\mathrm{ww} / \mathrm{dm}=0.80-0.90)$, pachyconic conch at $30 \mathrm{~mm}$ diameter $(\mathrm{ww} / \mathrm{dm}=0.65-0.80)$, and thinly pachyconic conch at $50 \mathrm{~mm}$ diameter $(\mathrm{ww} / \mathrm{dm}=0.60-0.65)$. Umbilicus very narrow in all stages larger than $10 \mathrm{~mm} \mathrm{dm}(\mathrm{uw} / \mathrm{dm}=0.08-0.18)$; umbilical wall rounded. Ornamentation at $6 \mathrm{~mm} \mathrm{dm}$ with coarse, crenulated biconvex and prorsiradiate growth-lines; over $30 \mathrm{~mm}$ dm with $80-90$ granulated spiral lines as well as crenulated, biconvex and rectiradiate growth lines with low dorsolateral projection and higher ventrolateral projection; external sinus deep. Weak constrictions of the shell cause a falcate ornament in the adult stage. Suture line with Y-shaped, moderately wide external lobe $(0.70-0.75$ of the external lobe depth, 1.00 1.20 of the adventive lobe), and moderately high median saddle (slightly above 0.50 of the external lobe depth). Flanks of the external lobe strongly sinuous, ventrolateral saddle subacute, adventive lobe Vshaped with inflexed flanks.

Description. Ontogenetic changes in conch form are well visible in the species. A juvenile thickly pachyconic and evolute stage $(\mathrm{ww} / \mathrm{dm}=0.80, \mathrm{uw} / \mathrm{dm}=0.35-$ 0.40 at $2 \mathrm{~mm} \mathrm{dm}$ ) is replaced by a globular involute stage at $5-8 \mathrm{~mm} \mathrm{dm}(\mathrm{ww} / \mathrm{dm}=0.85-1.00, \mathrm{uw} / \mathrm{dm} \mathrm{de}-$ creasing to 0.12 ), followed by a continuous decreasing of the ww/dm ratio to 0.60 in the adult stage. The uw/ $\mathrm{dm}$ ratio stabilizes at $\mathrm{uw} / \mathrm{dm}=0.08-0.18$ (Fig. 50G). The aperture is very low in all stages between 2 and $30 \mathrm{~mm} \mathrm{dm}$ (WER around 1.50) and shows a slight increase in height in the adult stage (1.70-1.80; Fig. 50H).

The material from Chebket el Hamra suggests that intraspecific variability is particularly well expressed in the growth interval between 4 and $30 \mathrm{~mm}$ conch diameter. The sectioned specimens MB.C.13206.1 (cuboid form; Fig. 50A) and MB.C.13206.2 (non-cuboid form; Fig. 50B) demonstrate the range of variability, with cross section MB.C.13247.2 being an intermediate form (Fig. 50C).

The largest specimens are incompletely preserved and somewhat distorted. Paratype MB.C.13250.1 is such a specimen; it has a ww/dm ratio of 0.63 at 

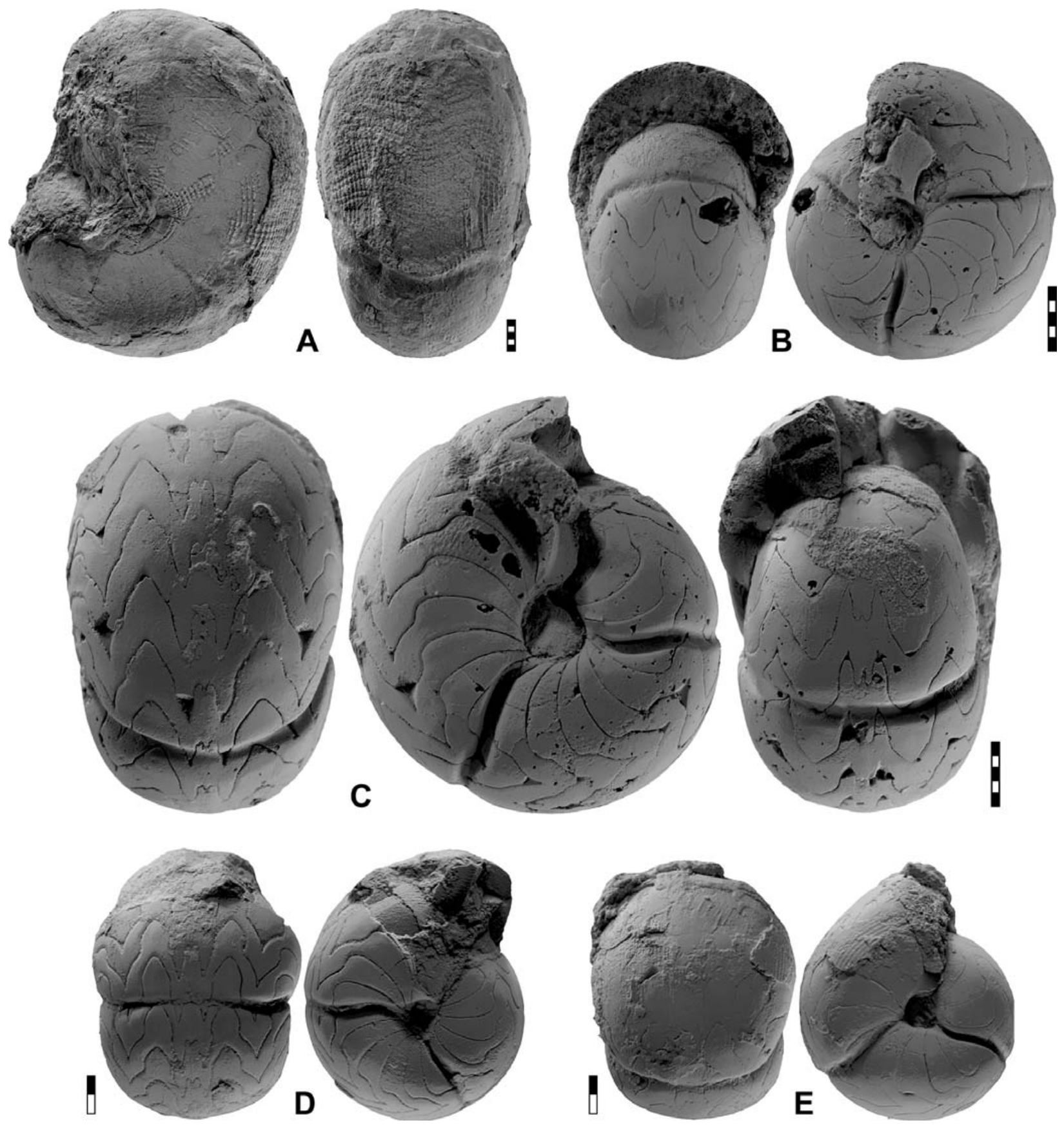

Figure 49. Lusitanoceras zirari n. sp. A. Paratype MB.C.13250.1 from locality Chebket el Hamra-L; $\times 1.0$. B. Paratype MB.C.13288 from Chebket el Hamra; × 2.0. C. Holotype MB.C.13296 from Chebket el Hamra; × 2.0. D. Paratype MB.C.13247.1 from locality Chebket el Hamra-K; × 3.0. E. Paratype MB.C.13261.1 from locality Chebket el Hamra-P; $\times 3.0$.

$55 \mathrm{~mm}$ conch diameter (Fig. 49A). It possesses shell remains, which show the falcate ornament composed of rhythmic narrow-spaced constrictions, crossing the coarse and granulated spiral lines, of which approximately 90 can be counted from umbilicus to umbilicus.

Some of the smaller specimens are well preserved as limonitic internal moulds. The largest of these, holotype MB.C.13296 with $31 \mathrm{~mm}$ conch diameter, is fully septate with about 20 chambers (Fig. 49C). It is thinly pachyconic $(\mathrm{ww} / \mathrm{dm}=0.69)$ with a narrow umbilicus $(\mathrm{uw} / \mathrm{dm}=0.16)$ and represents the typical conch geo- metry of the species. The last volution of the specimen possesses three deep constrictions of the steinkern, standing in angles of $120^{\circ}$. They extend with a low dorsolateral projection in slight backward direction across the flank to form a very low ventrolateral projection and a very low ventral sinus. The steinkern possesses traces of approximately 100 spiral lines.

Paratype MB.C.13288 belongs to the more slender specimens (Fig. 49B); at $23.5 \mathrm{~mm}$ conch diameter the $\mathrm{ww} / \mathrm{dm}$ ratio is 0.74 and the $u w / \mathrm{dm}$ ratio 0.15 . It also shows three steinkern constrictions, but these are ar- 

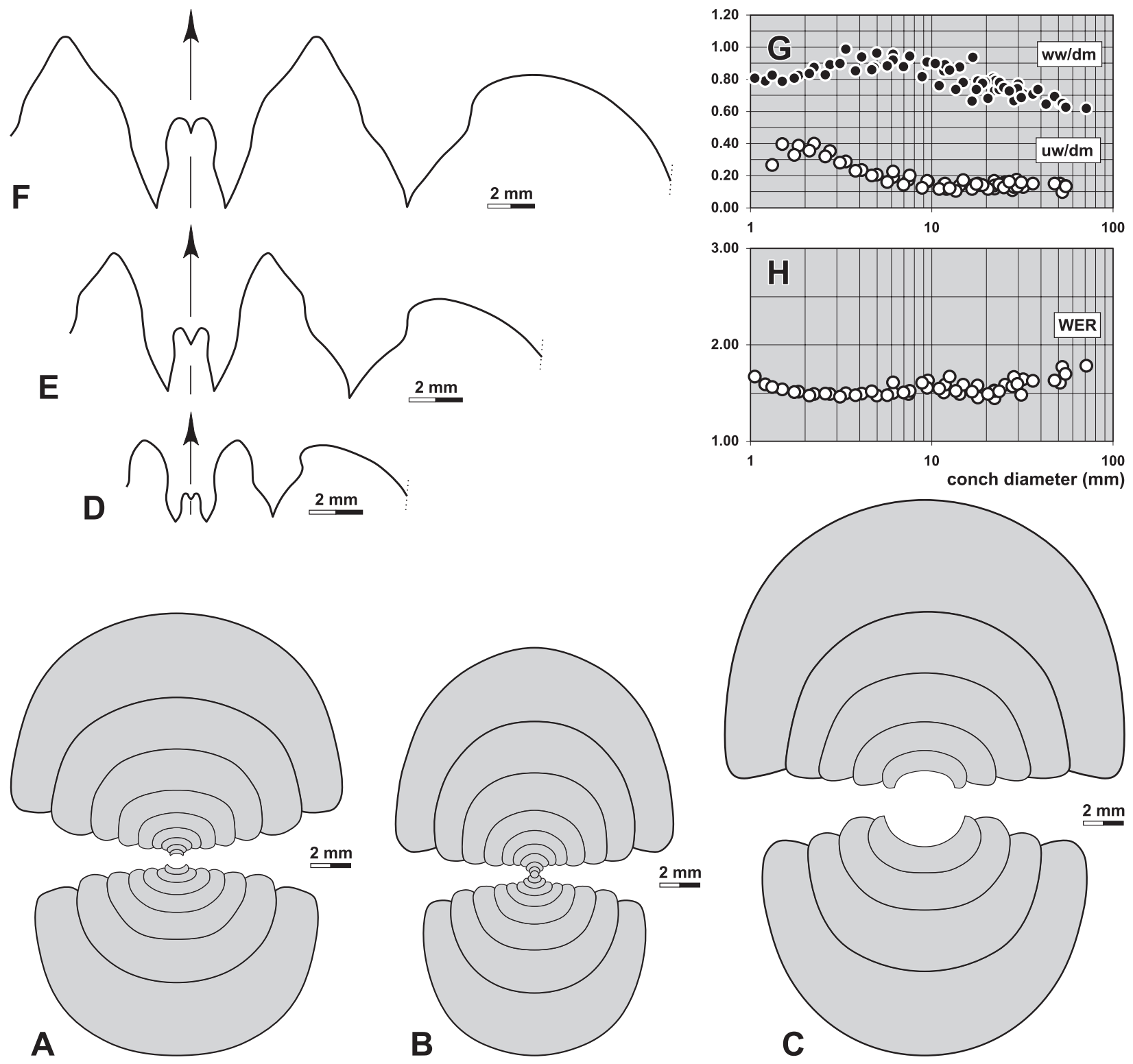

Figure 50. Lusitanoceras zirari n. sp. A. Cross section of paratype MB.C.13206.1 from locality Chebket el Hamra-D; $\times 3.0$. B. Cross section of paratype MB.C.13206.2 from locality Chebket el Hamra-D; × 3.0. C. Cross section of paratype MB.C.13247.2 from locality Chebket el Hamra-K; $\times 3.0$. D. Suture line of paratype MB.C.13261.1 from locality Chebket el Hamra-P, at $10.4 \mathrm{~mm}$ ww, $9.4 \mathrm{~mm}$ wh; $\times$ 4.0. E. Suture line of paratype MB.C.13288 from Chebket el Hamra, at $20.4 \mathrm{~mm} \mathrm{dm}, 15.5 \mathrm{~mm}$ ww, $10.7 \mathrm{~mm}$ wh; $\times$ 4.0. F. Suture line of holotype MB.C.13296 from Chebket el Hamra, at $30.6 \mathrm{~mm} \mathrm{dm}, 21.3 \mathrm{~mm}$ ww, $13.8 \mathrm{~mm}$ wh; $\times 3.5$. G, H. Ontogenetic development of the conch width index (ww/dm), umbilical width index $(\mathrm{uw} / \mathrm{dm})$ and whorl expansion rate (WER) of all available specimens.

ranged with slightly irregular distances. They extend across flanks and venter with a low dorsolateral projection, a shallow lateral sinus and a wide and low ventral projection.

Two smaller well-preserved steinkern specimens MB.C.13247.1 and MB.C.13261.1, both with about $12 \mathrm{~mm}$ conch diameter, give an impression of the variable morphology at this growth stage (Figs 49D, E). Both are similar in their globular shape (ww/ $\mathrm{dm}=0.86-0.88$ ) and their very narrow umbilicus (uw/ $\mathrm{dm}=0.12-0.14)$. They differ in the strength of the constrictions, which are arranged more or less at intervals of $120^{\circ}$. They are weaker on the midventer in spe- cimen MB.C.13247.1. Both specimens show traces of the spiral ornament, which consists of 70-80 fine lines.

The three figured suture lines demonstrate the significant ontogenetic changes in this feature (Figs 50D-F). A Y-shaped, partly parallel-sided external lobe is present in the juvenile stage (specimen MB.C.13261.1, $10 \mathrm{~mm} \mathrm{dm}$ ), and the median saddle reaches one third of the E lobe depth. The pouched adventive lobe has strongly curved flanks.

An ontogenetic trend towards a widening of the sutural elements can be seen in the studied specimens. The shape of the external lobe changes strikingly, being 

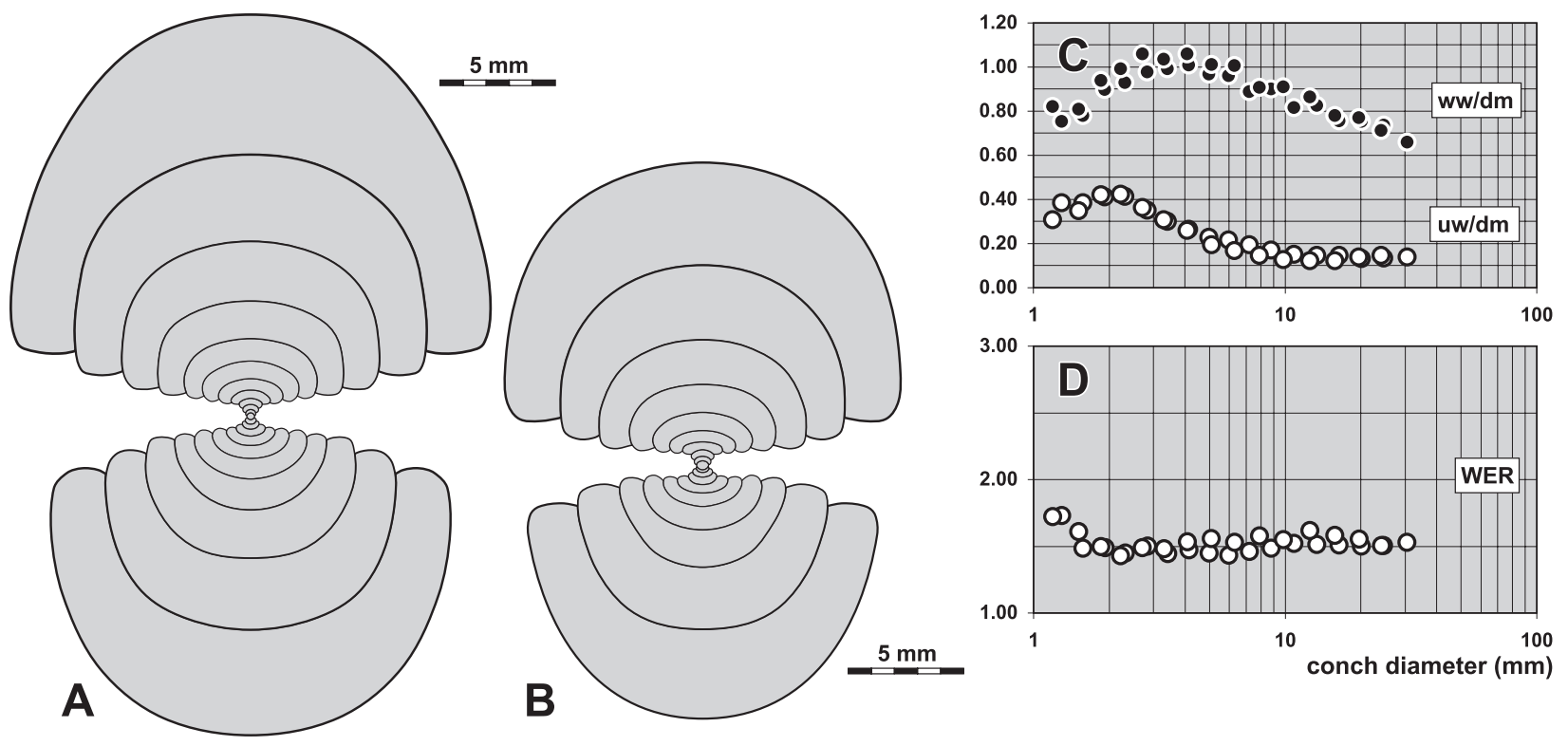

Figure 51. Lusitanoceras poststriatum (Brüning, 1923) from the Rhenish Mountains. A. Cross section of specimen MB.C.13307 (cuboid variant) from Mälers Länder (Korn 1986 Coll.); $\times 2.5$. B. Cross section of specimen MB.C.13303 (non-cuboid variant) from Nehden (Korn 1986 Coll.); $\times 2.5$. C, D. Ontogenetic development of the conch width index (ww/dm), umbilical width index (uw/dm) and whorl expansion rate (WER) of the two sectioned specimens.

moderately wide in paratype MB.C.13288 $(20 \mathrm{~mm} \mathrm{dm}$; Fig. 50E) and widely Y-shaped in holotype MB.C.13296 (30 mm dm; Fig. 50F). In the latter, the flanks are strongly sinuous with a sharp bend at half height, above which the flanks diverge prominently. At this stage, the height of the median saddle is slightly more than 0.50 of the external lobe depth. The subacute ventrolateral saddle is almost symmetric in holotype MB.C.13296. While the flanks of the ventral lobe become more sinuous during ontogeny, the flanks of the adventive lobe lose their strong sinuosity of the juvenile stage. However, rather sharp bends are still visible at half the depth of the adventive lobe.

Discussion. The similar species L. algarviense is so far only known from crushed or otherwise incompletely preserved material (Korn 1997), but never the less it can easily be distinguished from the well preserved new material from Chebket el Hamra. The two species differ mainly in the strength of the spiral ornament, with 110 spiral lines at $10-12 \mathrm{~mm} \mathrm{dm}$ in L. algarviense and only $70-80$ in L. zirari. This difference is even more striking in adult specimens, with $80-100$ spirals in L. zirari and approximately 150 in L. algarviense.

The new material shows that the differences with the other European species L. poststriatum (Brüning, 1923) are most discernible in adult specimens (lack of the falcate ornament and straight constrictions in L. poststriatum). Juvenile conchs, however, are very similar and may be difficult to separate. As demonstrated by Brüning (1923a) and Korn (1988), L. poststriatum occurs, like L.zirari, in cuboid and non-cuboid variants (Fig. 51). This phenomenon was analysed by Korn et al. (2004) for a number of goniatites. The number of spiral lines is higher in L.poststriatum (more than 100 at $12 \mathrm{~mm} \mathrm{dm}$ ).

More difficult is a clear separation from the still problematic Irish species L. granosum (Portlock, 1843), of which no additional material has been collected. The partly crushed original specimen shows fewer spiral lines and no indication of a falcate ornament.

\section{Subfamily Sudeticeratinae Korn \& Ebbighausen, 2006}

Included genus.

Sudeticeras Patteisky, 1930.

Discussion. Based on similarities in the suture lines Sudeticeras was usually included in subfamily Sudeticeratinae along with Anthracoceras Frech, 1899 in the Anthracoceratidae Plummer \& Scott, 1937 (see for instance Ruzhencev \& Bogoslovskaya 1971, who also attributed Beyrichoceras to this family). This arrangement cannot be supported because of major differences in the conch shapes between these genera, with Anthracoceras possessing a high aperture; in addition the suture line of Sudeticeras shows a clear development from a goniatitid origin, but in Anthracoceras it is very simple with very low median saddle and small and rounded adventive lobe. Therefore, Korn \& Ebbighausen (in Klug et al. 2006) erected the new family Sudeticeratidae, which will be downgraded here to the rank of subfamily and placed in the Goniatitidae.

The new material shows that the stratigraphically oldest species of Sudeticeras are very close to representatives of genera such as Hibernicoceras and Paragly- 
phioceras, and that there appears to be an almost continuous morphocline between these genera. The conch ontogeny of Sudeticeras closely resembles these two genera, and the suture line also indicates close relationships. These data suggest that Sudeticeras derives from the Goniatitida as a side branch, in which the ventrolateral saddle became secondarily rounded as in other representatives such as Hibernicoceras. The Sudeticeras group is therefore thought to represent a subfamily within the Goniatitidae.

\section{Sudeticeras Patteisky, 1930}

Type species. Homoceratoides Hoeferi Patteisky, 1929.

Discussion. Sudeticeras is a genus with an almost global occurrence (except for central North America) and 27 valid species are listed in the AMMON database (Korn \& Ilg 2007). Unfortunately, many of these species, including the type material, are based on insufficiently preserved material and are thus very difficult to interpret. Seventeen of the species were erected on material from Europe; few of these were described with the full inventory of conch geometry, ornament, and suture line. Therefore Sudeticeras can be regarded as a somewhat problematic genus.

The Western and Central European species of Sudeticeras can be grouped as follows:

A - species with a wide external lobe (1.50 of the adventive lobe width or more):

S. regina Bisat, 1952: very slender form (ww/ $\mathrm{dm}=0.54$ at $39 \mathrm{~mm} \mathrm{dm}$ ) with fine crenulated growth lines and without spiral lines, very low ventrolateral projection of the growth lines;

S. murracaoense Korn, 1997: slender form (ww/ $\mathrm{dm}=0.60$ at $25 \mathrm{~mm} \mathrm{dm}$ ) with fine, barely crenulated growth lines and without spiral lines, very low ventrolateral projection of the growth lines;

S. turneri Moore \& Hodson, 1958: slender form $(\mathrm{ww} / \mathrm{dm}=0.60$ at $30 \mathrm{~mm} \mathrm{dm}$ ) with fine crenulated growth lines and without spiral lines, moderate ventrolateral projection of the growth lines;

S. varians (Bisat, 1950): very slender form (ww/ $\mathrm{dm}=0.48$ at $25 \mathrm{~mm} \mathrm{dm}$ ) with delicate growth lines but without spiral lines, moderate ventrolateral projection of the growth lines.

B - species with a rather narrow external lobe (less than 1.50 of the adventive lobe) and a moderately narrow umbilicus (uw/dm more than 0.15):

S. newtonense Moore, 1950: very slender form (ww/ $\mathrm{dm}=0.55$ at $38 \mathrm{~mm} \mathrm{dm}$ ) with fine crenulated growth lines and without spiral lines, very low ventrolateral projection of the growth lines;

S. adeps Moore, 1950: stout form $(\mathrm{ww} / \mathrm{dm}=0.80$ at $20 \mathrm{~mm} \mathrm{dm}$ ) with roughened growth lines and without spiral lines, very low ventrolateral projection of the growth lines.
C - species with a rather narrow external lobe (less than 1.50 of the adventive lobe), a very narrow umbilicus (uw/dm less than 0.15 ), and a rather prominent ventrolateral projection of the growth lines:

S. splendens (Bisat, 1928): slender form (ww/ $\mathrm{dm}=0.67$ at $25 \mathrm{~mm} \mathrm{dm}$ ) with spiral lines on venter and ventrolateral shoulder;

$S$. horoni n. sp.: very slender form $(\mathrm{ww} / \mathrm{dm}=0.55-$ 0.65 at $24 \mathrm{~mm} \mathrm{dm}$ ) with spiral lines on venter, ventrolateral shoulder, and around the umbilicus;

S. ordinatum Moore, 1950: stout form (ww/ $\mathrm{dm}=0.75$ at $25 \mathrm{~mm} \mathrm{dm}$ ) with spiral lines on venter, ventrolateral shoulder, and flanks;

S. subtilis Moore, 1950: very slender form (ww/ $\mathrm{dm}=0.57$ at $21 \mathrm{~mm} \mathrm{dm}$ ) with fine crenulated growth lines and without spiral lines.

D - species with a rather narrow external lobe (less than 1.50 of the adventive lobe), a very narrow umbilicus (uw/dm less than 0.12 ), and without or with a very low ventrolateral projection of the growth lines:

S. crenistriatum (Bisat, 1928): very slender form $(\mathrm{ww} / \mathrm{dm}=0.58$ at $24 \mathrm{~mm} \mathrm{dm})$ with fine crenulated growth lines and without spiral lines;

S. procerum Moore, 1950: slender form (ww/ $\mathrm{dm}=0.62$ at $21 \mathrm{~mm} \mathrm{dm}$ ) with fine crenulated growth lines and few spiral lines around the umbilicus;

S. delepinei Moore, 1950: very slender form (ww/ $\mathrm{dm}=0.55$ at $27 \mathrm{~mm} \mathrm{dm}$ ) with fine crenulated growth lines and without spiral lines;

S. laevigatum Ruprecht, 1937: stout form (ww/ $\mathrm{dm}=0.70$ at $17 \mathrm{~mm} \mathrm{dm}$ ) with rather coarsely crenulated growth lines and without spiral lines, without ventrolateral projection of the growth lines.

\section{Sudeticeras murracaoense Korn, 1997}

Figures 52-54

1997 Sudeticeras murracaoense Korn, p. 40, pl. 2, figs 6-8.

Holotype. Specimen IGML250 (Korn \& Horn 1995 Coll.); figured by Korn (1997, pl. 2, fig. 6).

Material. 382 limonitic steinkern specimens varying from a conch diameter of 5 and $22 \mathrm{~mm}$ from horizon $\mathrm{CeH}-3$ at localities Chebket el Hamra-A, B, C, and S.

Diagnosis. Sudeticeras with highly variable pachyconic conch at $10 \mathrm{~mm}$ diameter $(\mathrm{ww} / \mathrm{dm}=0.68-0.82)$ and thinly pachyconic conch at $20 \mathrm{~mm}$ diameter $(\mathrm{ww} / \mathrm{dm}=0.60-0.65)$. Umbilicus moderately wide in early juveniles ( $\mathrm{uw} / \mathrm{dm}=0.30$ at $2 \mathrm{~mm} \mathrm{dm}$ ) and then continuously closing (uw/dm $=0.05-0.10$ at $20 \mathrm{~mm} \mathrm{dm}$ ); umbilical margin broadly rounded, umbilical wall rounded. Ornamentation with delicate, crenulated rectiradiate growth-lines, which extend almost straight across the flanks and form a shallow ventral sinus; spiral lines lacking. Suture line with moderately wide external lobe $(0.70-$ 0.80 of the external lobe depth, $1.30-1.50$ of the adventive lobe), Vshaped in the juvenile stage and Y-shaped in the adult, and moderate median saddle ( 0.50 of the external lobe depth). Ventrolateral saddle narrowly rounded, adventive lobe V-shaped with strongly sinuous flanks. 

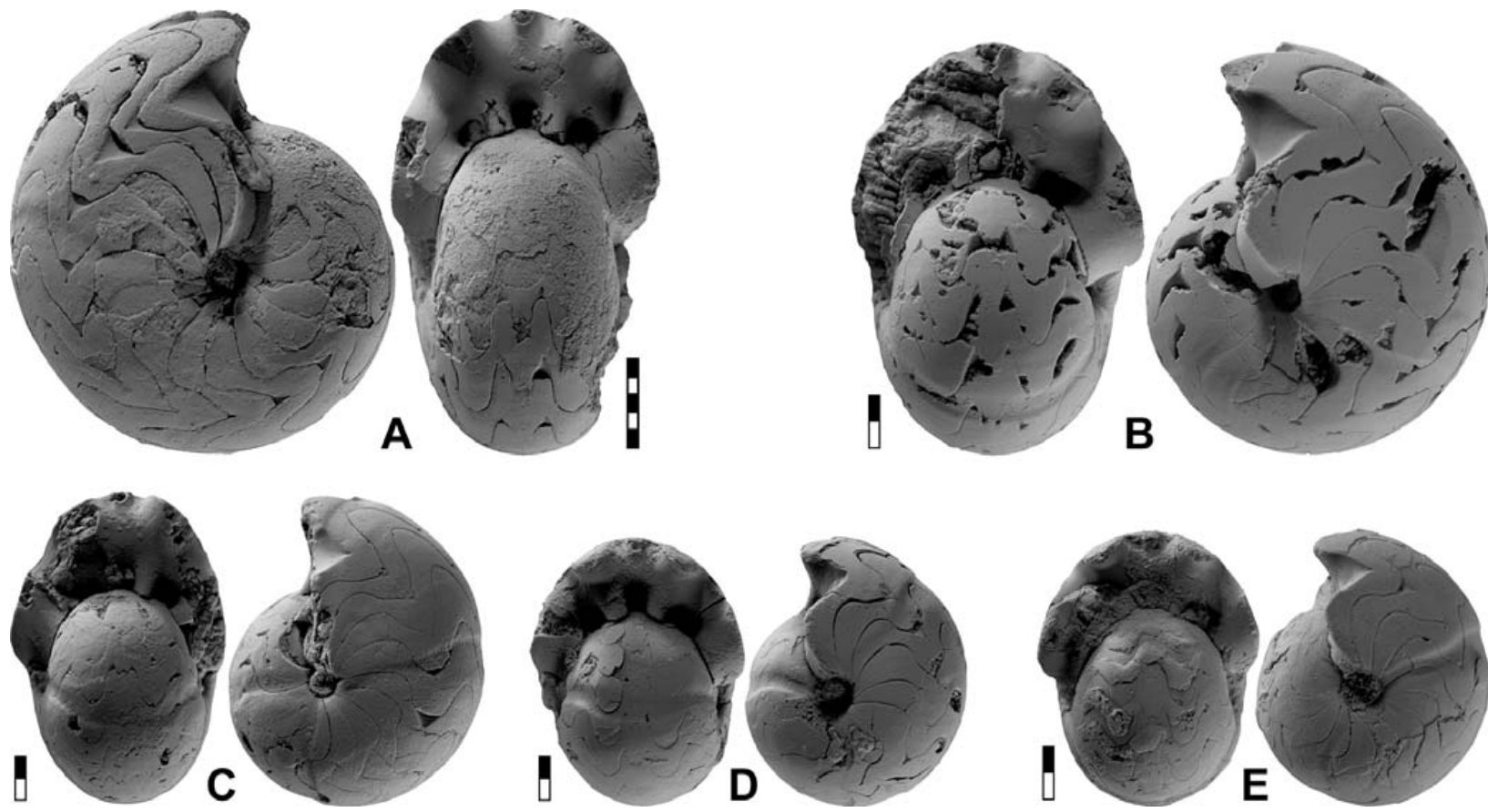

Figure 52. Sudeticeras murracaoense Korn, 1997. A. Specimen MB.C.13202.1 from locality Chebket el Hamra-A; $\times 2.0$. B. Specimen MB.C.13271.1 from locality Chebket el Hamra-S; $\times 3.0$. C. Specimen MB.C.13271.2 from locality Chebket el Hamra-S; $\times 2.5$. D. Specimen MB.C.13202.2 from locality Chebket el Hamra-A; $\times 2.5$. E. Specimen MB.C.13203.1 from locality Chebket el Hamra-B; $\times 3.0$.

Description. The plots of the major conch parameters show two phenomena (Figs 53G, H): (1) the ontogenetic changes from the moderately umbilicate, pachyconic to globular inner whorls with low aperture (ww/ $\mathrm{dm}=0.85, \mathrm{uw} / \mathrm{dm}=0.30, \mathrm{WER}=1.70$ at $2 \mathrm{~mm} \mathrm{dm})$ to the involute, thickly discoidal large stage with moderately high aperture $(\mathrm{ww} / \mathrm{dm}=0.55, \mathrm{uw} / \mathrm{dm}=0.10$, WER $=2.00-2.10$ at $25 \mathrm{~mm} \mathrm{dm}$ ). (2) the significant variability of the ww/dm ratio and the whorl expansion rate.

Only a few specimens have well-preserved inner whorls, and specimen MB.C.13271.3 is the best preserved of these (Fig. 53A). The cross section allows study of all inner whorls up to $14 \mathrm{~mm} \mathrm{dm}$; it displays the ontogenetic modifications beginning with an evolute initial stage and ending with the involute, pachyconic shape at $14 \mathrm{~mm} \mathrm{dm} \quad(\mathrm{ww} / \mathrm{dm}=0.66 ; \quad \mathrm{uw} /$ $\mathrm{dm}=0.07)$. The last half whorl shows a section that is widest at the rounded umbilical margin, from which the flanks converge toward the broadly rounded venter.

MB.C.13271.4 is one of the larger sectioned specimens in which the internal whorls are not preserved. The umbilical margin is more pronounced in this specimen and separates the converging flanks and the flattened umbilical wall.

Specimen MB.C.13202.1 belongs to the larger individuals (Fig. 52A); it is, at a diameter of nearly $25 \mathrm{~mm}$, thickly discoidal $(\mathrm{ww} / \mathrm{dm}=0.58)$ with a very narrow umbilicus (uw $/ \mathrm{dm}=0.08)$ and a moderately high aperture $($ WER $=2.02)$. It is fully septate with 16 chambers, of which the last are shorter than the average. The steinkern has weak constrictions, which extend with a very shallow lateral sinus and a deeper ventral sinus; remains of the shell show fine and crenulated growth lines with the same course.

Smaller specimens such as MB.C.13271.1 (15 mm $\mathrm{dm})$ and MB.C.13271.2 (13 $\mathrm{mm} \mathrm{dm})$ have a similar conch geometry (Figs 52B, C), but are somewhat stouter $(\mathrm{ww} / \mathrm{dm}=0.70)$. The umbilicus is very narrow in these two specimens $(\mathrm{uw} / \mathrm{dm}=0.07)$. Both show the same type of irregularly distributed constrictions on the steinkern, but no shell remains.

Juveniles such as specimen MB.C.13203.1 (10 mm $\mathrm{dm}$ ) tend to have a thickly discoidal conch (ww/ $\mathrm{dm}=0.79)$ with a lower aperture (WER $=1.87)$. The steinkern of this specimen has two broad and shallow constrictions, which extend almost straight across flanks and venter (Fig. 52E).

The atypical suture line of the large specimen MB.C.13202.1 (drawn at $23.5 \mathrm{~mm} \mathrm{dm}$ ) shows a Yshaped external lobe, whose lower part has nearly parallel flanks (Fig. 53F). A narrow median saddle, reaching the half height of the $\mathrm{E}$ lobe depth produces asymmetric prongs with strongly curved ventral flank. The ventrolateral saddle is strongly asymmetric and appears dorsally inclined. It is narrowly rounded at its top and continues into the deep and narrow adventive lobe.

Differences can be recognised in the suture line of the smaller specimens MB.C.13271.1 (15 mm dm) and MB.C.13203.1 (10 $\mathrm{mm} \mathrm{dm})$; these have a V-shaped external lobe with strongly diverging flanks (Figs 53D, E). 


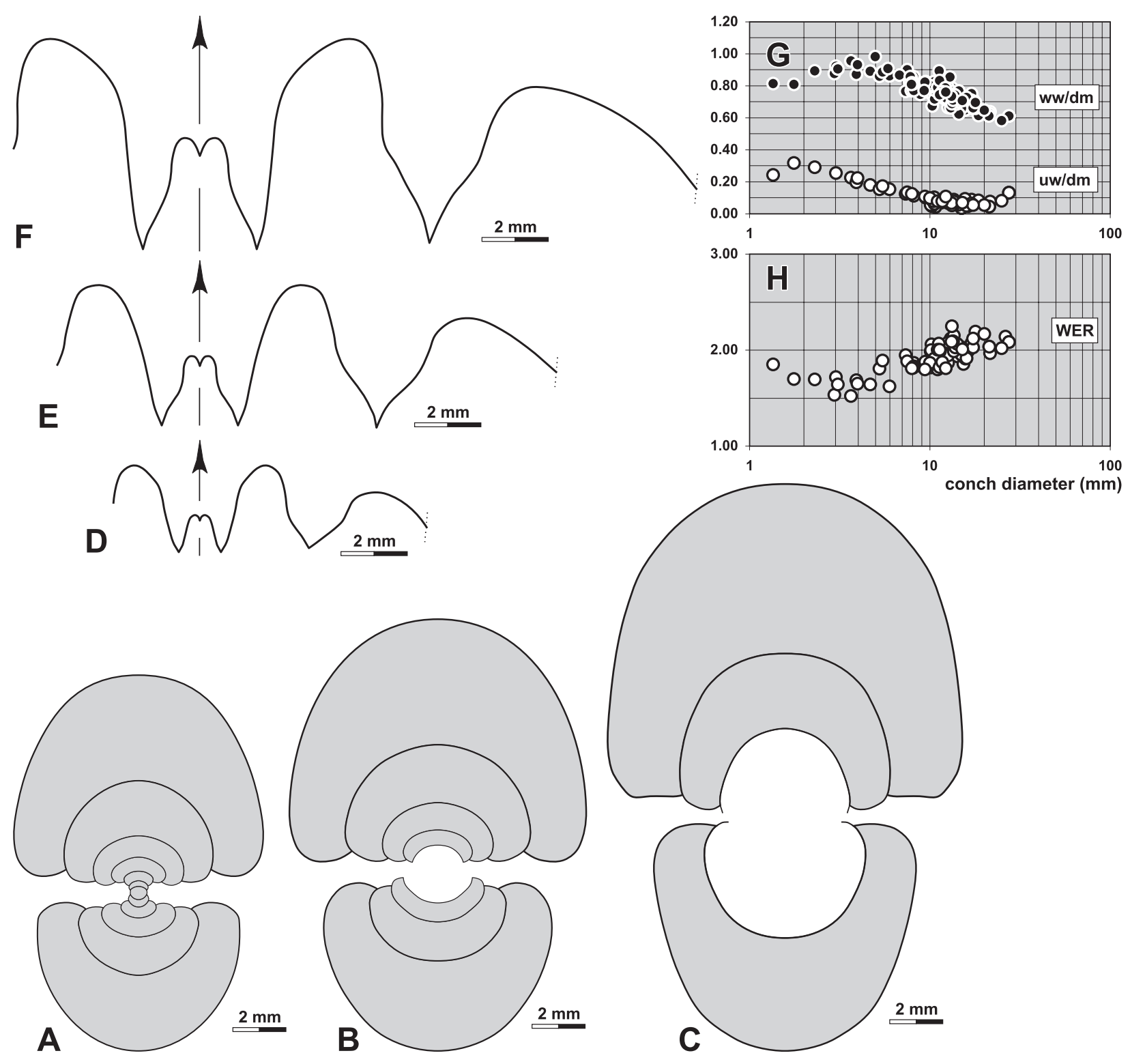

Figure 53. Sudeticeras murracaoense Korn, 1997. A. Cross section of specimen MB.C.13271.3 from locality Chebket el Hamra-S; $\times$ 4.0. B. Cross section of specimen MB.C.13205.1 from locality Chebket el Hamra-C; $\times 4.0$. C. Cross section of specimen MB.C.13271.4 from locality Chebket el Hamra-S; $\times$ 4.0. D. Suture line of specimen MB.C.13203.1 from locality Chebket el Hamra-B, at $10.3 \mathrm{~mm} \mathrm{dm}, 8.1 \mathrm{~mm}$ ww, $5.8 \mathrm{~mm}$ wh; $\times 5.0$. E. Suture line of specimen MB.C.13271.1 from locality Chebket el Hamra-S, at $15.1 \mathrm{~mm} \mathrm{dm}, 10.7 \mathrm{~mm}$ ww, $8.1 \mathrm{~mm}$ wh; $\times 5.0$. F. Suture line of specimen MB.C.13202.1 from locality Chebket el Hamra-A, at $23.6 \mathrm{~mm} \mathrm{dm}, 14.9 \mathrm{~mm}$ ww, $12.8 \mathrm{~mm}$ wh; $\times 5.0$. G, H. Ontogenetic development of the conch width index (ww/dm), umbilical width index (uw/dm) and whorl expansion rate (WER) of all available specimens.

Discussion. The material from the Chebket el Hamra closely resembles the Portuguese material in the development of conch shape and suture line (for a comparison, see Fig. 54). S. murracaoense is one of the few species of the genus that lacks spiral ornament, and can thus be separated from a number of other Sudeticeras species. Furthermore, the species has a wide external lobe with diverging flanks, which separates it from many other species with subparallel flanks of the external lobe. S. turneri Moore \& Hodson, 1958 is closely related but this species has an even wider external lobe and a higher ventrolateral projection of the growth lines.
Sudeticeras ibnbajjahi n. sp.

Figures 55-56

Derivation of name. After Ibn Bajjah (Avempace) one of the most important medieval Arab scientists.

Holotype. Specimen MB.C.13241.1 (Korn \& Ebbighausen 2006 Coll.); illustrated in Figure 55A.

Type locality and horizon. Chebket el Hamra-I (Jerada Basin, NEMorocco); horizon $\mathrm{CeH}-2$, most probably Neoglyphioceras spirale Zone (middle Brigantian, Early Carboniferous).

Material. 35 limonitic steinkern specimens ranging from 8 and $37 \mathrm{~mm}$ in conch diameter from horizon $\mathrm{CeH}-2$ at localities Chebket el Hamra-F, I, and T. 

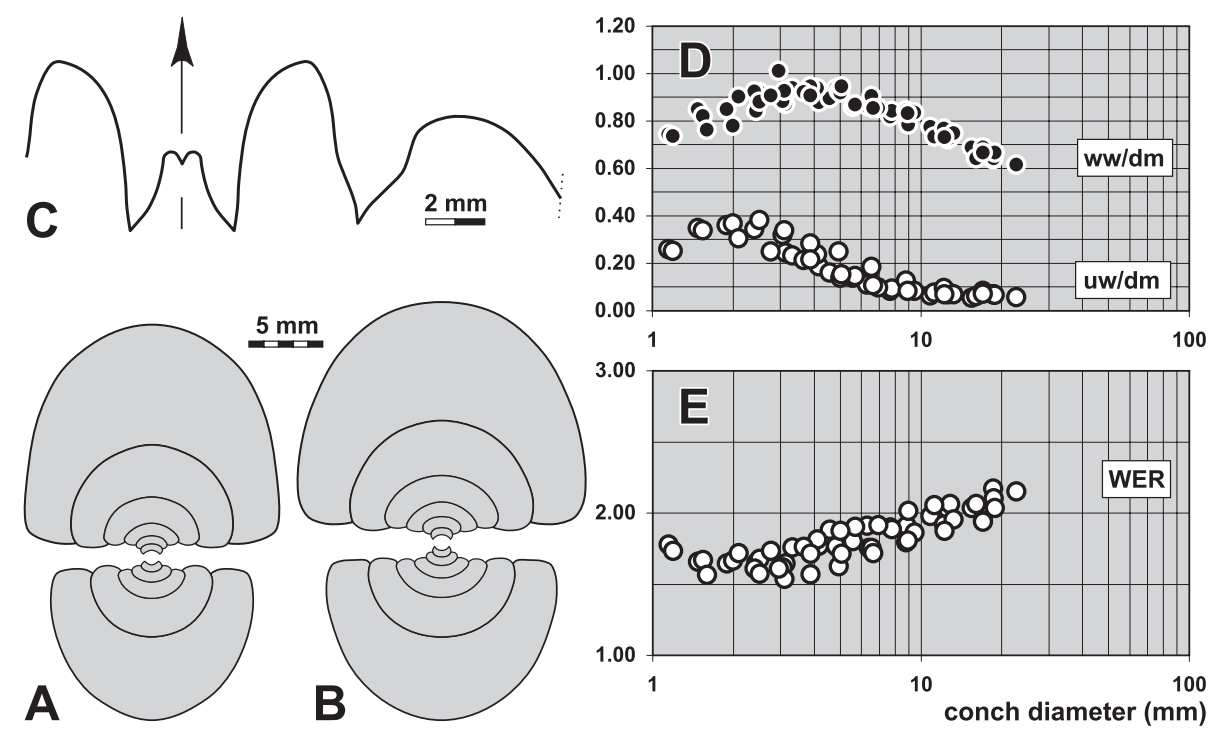

Figure 54. Sudeticeras murracaoense Korn, 1997 from bed 145 of the Praia das Quebradas section, SW Portugal (Korn 2000 Coll.). A. Cross section of specimen MB.C.13313.1; $\times 2.5$. B. Cross section of specimen MB.C.13313.2; $\times 2.5$. C. Suture line of specimen MB.C.13313.8, at $16.5 \mathrm{~mm} \mathrm{dm}, 11.8 \mathrm{~mm}$ ww, $8.6 \mathrm{~mm}$ wh; x 3.0. D, E. Ontogenetic development of the conch width index $(\mathrm{ww} / \mathrm{dm})$, umbilical width index $(\mathrm{uw} / \mathrm{dm})$ and whorl expansion rate (WER) of the seven sectioned specimens MB.C.13313.1-MB.C.13313.7.

\begin{abstract}
Diagnosis. Sudeticeras with thickly pachyconic conch at $10 \mathrm{~mm}$ diameter $(\mathrm{ww} / \mathrm{dm}=0.75-0.85)$ and thinly pachyconic conch at $20 \mathrm{~mm}$ diameter $(\mathrm{ww} / \mathrm{dm}=0.60-0.65)$. Umbilicus very narrow in specimens larger than $8 \mathrm{~mm} \mathrm{dm}(\mathrm{uw} / \mathrm{dm}=0.05-0.15)$, in the adult stage slightly opening; umbilical margin broadly rounded, umbilical wall rounded. Ornamentation with delicate, weakly crenulated rectiradiate growthlines, which extend almost straight across the flanks and form a shallow external sinus; spiral lines lacking. Suture line with V-shaped, moderately wide external lobe $(0.70$ of the external lobe depth, 1.30 of the adventive lobe), and moderate median saddle ( 0.45 of the external lobe depth). Ventrolateral saddle narrowly rounded, adventive lobe V-shaped with weakly sinuous flanks.
\end{abstract}

Description. The morphometric plots demonstrate that the short early juvenile growth stage individuals possess a moderately wide umbilicus (uw/dm $=0.30-0.35$ at $1.5-2 \mathrm{~mm} \mathrm{dm}$ ), with a rapid closure of the umbilicus (uw $/ \mathrm{dm}=0.10$ at $5 \mathrm{~mm} \mathrm{dm}$ ), and a very narrow umbilicus in all later stages (Fig. 56H). The conch is widest at $4 \mathrm{~mm} \mathrm{dm}(\mathrm{ww} / \mathrm{dm}=1.00)$ and becomes continuously narrower during growth, being thickly discoidal at $37 \mathrm{~mm} \mathrm{dm}(\mathrm{ww} / \mathrm{dm}=0.56)$. During ontogeny, there is a continuous heightening of the aperture, visible in the increase of the whorl expansion rate from 1.70 at $2 \mathrm{~mm} \mathrm{dm}$ to 2.00 at $20 \mathrm{~mm} \mathrm{dm} \mathrm{(Fig.} \mathrm{56I).}$

The two cross sections show similar pictures. Paratype MB.C.13225.4 is the more complete of these; it has a maximum diameter of almost $15 \mathrm{~mm}$ and displays five and a half whorls (Fig. 56B). Early whorls are ventrally depressed and semilunate in cross section (ww/ $\mathrm{dm}=1.00$ at $4.8 \mathrm{~mm} \mathrm{dm}$ ), but an increase in height of the aperture leads to the thinly pachyconic conch at $15 \mathrm{~mm} \mathrm{dm}(\mathrm{ww} / \mathrm{dm}=0.67)$. The umbilical margin and also the umbilical wall are rounded in all stages.

The incompletely preserved holotype MB.C.13241.1 with a conch diameter of $21 \mathrm{~mm}$ belongs among the largest specimens (Fig. 55A). It is thinly pachyconic (ww/dm appr. 0.67) with a rather high aperture $(\mathrm{WER}=2.02)$ and is fully septate with a smooth internal mould. Two very weak constrictions are visible; they extend straight across the flanks and form a shallow ventral sinus.
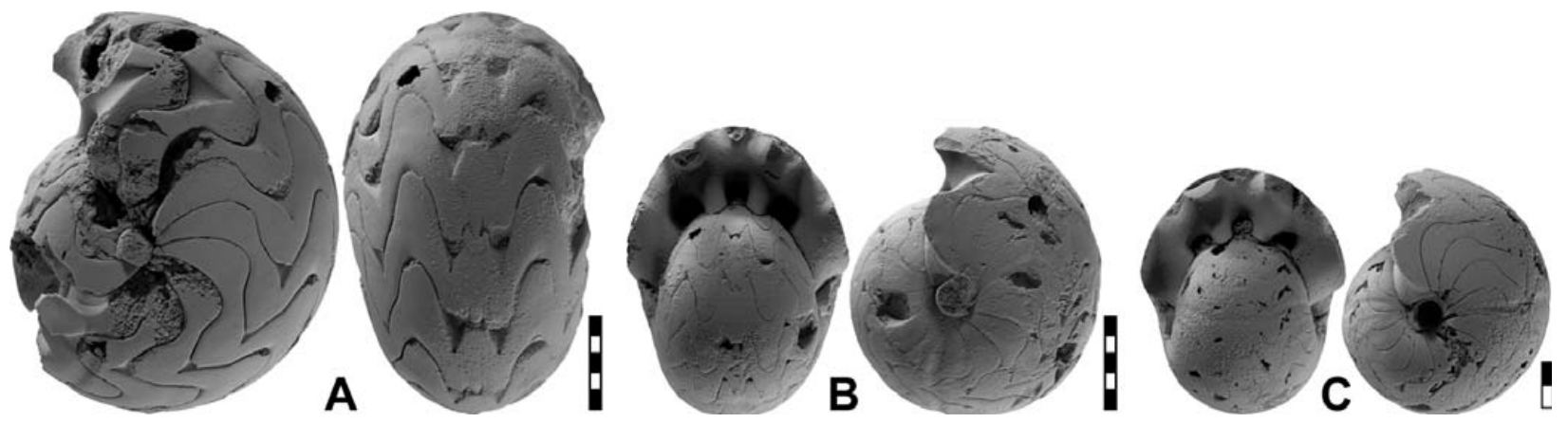

Figure 55. Sudeticeras ibnbajjahi n. sp. A. Holotype MB.C.13241.1 from locality Chebket el Hamra-I; $\times 2.0$. B. Specimen MB.C.13225.1 from locality Chebket el Hamra-F; $\times 2.0$. C. Specimen MB.C.13225.2 from locality Chebket el Hamra-F; $\times 2.5$. 


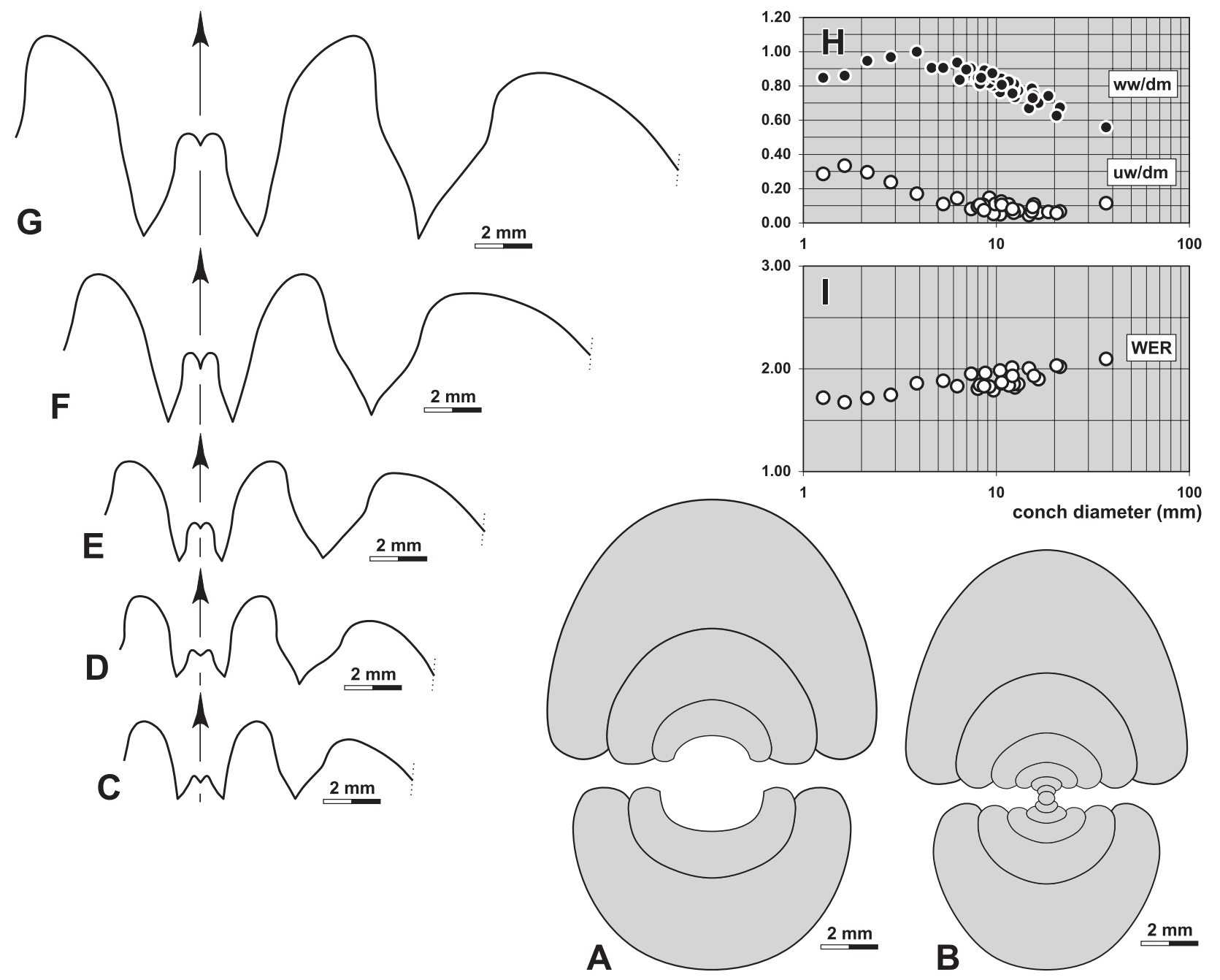

Figure 56. Sudeticeras ibnbajjahi n. sp. A. Cross section of paratype MB.C.13225.3 from locality Chebket el Hamra-F; $\times 4.0$. B. Cross section of paratype MB.C.13225.4 from locality Chebket el Hamra-F; × 4.0. C. Suture line of paratype MB.C.13225.2 from locality Chebket el Hamra-F, at $10.3 \mathrm{~mm}$ dm, $8.6 \mathrm{~mm}$ ww, $5.8 \mathrm{~mm}$ wh; × 4.0. D. Suture line of paratype MB.C.13225.5 from locality Chebket el Hamra-F, at $11.3 \mathrm{~mm} \mathrm{dm}, 9.3 \mathrm{~mm}$ ww, $6.1 \mathrm{~mm}$ wh; $\times 4.0$. E. Suture line of paratype MB.C.13225.1 from locality Chebket el Hamra-F, at $15.1 \mathrm{~mm} \mathrm{dm}, 11.7 \mathrm{~mm}$ ww, $8.6 \mathrm{~mm}$ wh; $\times 4.0$. F. Suture line of holotype MB.C.13241.1 from locality Chebket el Hamra-I, at $20.0 \mathrm{~mm} \mathrm{dm}, 10.3 \mathrm{~mm}$ wh; $\times 4.0$. G. Suture line of paratype MB.C.13280.1 from locality Chebket el Hamra-T, at $13.6 \mathrm{~mm}$ wh; $\times$ 4.0. H, I. Ontogenetic development of the conch width index (ww/dm), umbilical width index (uw/ $\mathrm{dm})$ and whorl expansion rate (WER) of all available specimens.

Paratype MB.C.13225.1 shows the characteristic morphology of the immature stage $(\mathrm{ww} / \mathrm{dm}=0.75, \mathrm{uw} /$ $\mathrm{dm}=0.11, \mathrm{WER}=1.93$ at $15 \mathrm{~mm} \mathrm{dm})$. The specimen possesses some minor remains of the shell, which show that the delicate, finely crenulated growth lines extend almost straight across the flanks and form a shallow ventral sinus. The steinkern has two very shallow constrictions (Fig. 55B).

Suture lines of the adult stage have a Y-shaped external lobe, of which the flanks are particularly strongly diverging in the upper quarter (paratype MB.C.13280.1 at $13 \mathrm{~mm}$ whorl height; Fig. 56G). The external lobe is wide ( 0.80 of the lobe depth at half height; 1.55 of the adventive lobe) and is subdivided by a median saddle that has the half height of the E lobe depth. The ventrolateral saddle is asymmetric and narrowly rounded, and the adventive lobe is deep with curved flanks.
The suture line of holotype MB.C.13241.1, drawn at $20 \mathrm{~mm}$ conch diameter, displays the $\mathrm{V}$-shaped external lobe with almost linear flanks in the lower three quarters (Fig. 56F). The median saddle is raised to nearly half the height of the external lobe and generates two slightly asymmetric prongs of the external lobe. A slightly asymmetric ventrolateral saddle follows, and then a V-shaped adventive lobe with barely curved ventral and strongly sinuous dorsal flank.

The smaller specimens MB.C.13225.1 (15 mm dm) and MB.C.13225.2 (10 $\mathrm{mm} \mathrm{dm})$ principally resemble the suture line of MB.C.13241.1, but have a lower median saddle and a broader rounded ventrolateral saddle (Figs 56C, E).

Discussion. Sudeticeras ibnbajjahi is the species that shows most resemblance to species of other genera, 
such as Hibernicoceras and Paraglyphioceras. The resemblance is close particularly among juvenile conchs, but distinguishable differences can be seen in the suture line. S. ibnbajjahi possesses an external lobe in which the prongs are strikingly asymmetric, with the flanks of the median saddle being characteristically concave.

Sudeticeras murracaoense is very similar in conch geometry and suture line, but possesses strong steinkern constrictions in juveniles, which are only very weakly developed in S. ibnbajjahi. S. murracaoense has a higher aperture in specimens between 15 and $25 \mathrm{~mm} \mathrm{dm}$ (WER $=2.00-2.20)$ in contrast to S. ibnbajjahi, in which it is below 2.00 .

\section{Sudeticeras splendens (Bisat, 1928)}

Figures 57-60

1928 Goniatites crenistriatus var. splendens Bisat, p. 43, pl.6A, fig. 3.

1929 Sudeticeras stolbergi Patteisky, p. 279, pl. 15, figs 1-2, pl. 20, figs $10 \mathrm{a}, 10 \mathrm{~b}, 11$, pl. 15 , fig. 3 , pl. 22, fig. 6, pl. 23, figs 29-30.

1931 Glyphioceras stolbergi. - Knopp, p. 19, pl. 3, figs 1-6.

1937 Sudeticeras stolbergi. - Ruprecht, p. 269, pl. 9, figs 10-15.

1950 Sudeticeras splendens. - Moore, p. 40, pl. 1, figs 3-5, pl. 2, fig. 6, pl. 3, figs $4-5$.

1988 Sudeticeras splendens. - Korn, p. 43, pl. 15, fig. 7.

Holotype. Specimen NHM c33151 (Moore Coll.); figured by Bisat (1928, pl. 6A, figs 3, 3a).

Type locality and horizon. Eastby Beck near Skipton (West Yorkshire, Great Britain); P2 Zone (Late Viséan)

Material. 46 limonitic steinkern specimens ranging from conch diameter of 30 to $58 \mathrm{~mm}$ from horizon CeH-6 at localities Chebket el Hamra-D, L, M, O, P, and R.

Diagnosis. Sudeticeras with thickly discoidal conch at $10 \mathrm{~mm}$ diameter $(\mathrm{ww} / \mathrm{dm}=0.75)$, thickly discoidal to thinly pachyconic conch at $30 \mathrm{~mm}$ diameter $(\mathrm{ww} / \mathrm{dm}=0.55-0.65)$, and thickly discoidal conch at $50 \mathrm{~mm}$ diameter $(\mathrm{ww} / \mathrm{dm}=0.45-0.55)$. Umbilicus very narrow in stages between 10 and $30 \mathrm{~mm} \mathrm{dm}$ (uw $/ \mathrm{dm}=0.08-0.12$ ), but opening slightly in the adult stage (uw/dm $=0.15-0.20$ at $50 \mathrm{~mm}$ $\mathrm{dm}$ ); umbilical wall oblique, incurved in the adult stage. Ornamentation with crenulated biconvex and rectiradiate growth-lines having a low dorsolateral projection and pronounced ventrolateral projection; external sinus deep. Spiral lines around the umbilicus and on the out- er flanks and venter. Suture line with V-shaped, moderately wide external lobe (0.65-0.75 of the external lobe depth, $1.30-1.40$ of the adventive lobe), and moderate median saddle ( 0.50 of the external lobe depth). Ventrolateral saddle rounded, adventive lobe V-shaped with weakly sinuous flanks.

Description. Nearly all attempts to produce a usable cross section failed, and hence only the growth stages from conch diameters 14 to $60 \mathrm{~mm}$ can be studied (Figs 58C, D). Ontogenetic changes during this interval are best seen in the ww/dm ratio, which continuously decreases from 0.71 at $14 \mathrm{~mm} \mathrm{dm}$ to 0.47 at $58 \mathrm{~mm}$ $\mathrm{dm}$. The uw/dm ratio remains almost stable during this growth interval; there is only a slight increase from 0.13 to 0.17 . The aperture also becomes higher, resulting in an increase of the whorl expansion rate from 1.74 to approximately 2.00 .

The sectioned specimen MB.C.13248.1 shows the compressed whorl cross section $(\mathrm{ww} / \mathrm{dm}=0.51$ at $47 \mathrm{~mm} \mathrm{dm}$ ) with the rounded flanks converging toward the broadly rounded venter (Fig. 58A). The umbilical margin is rounded, and the umbilical wall is obliquely oriented and, in the last two volutions, sinuously curved in the section.

Larger specimens, such as MB.C.13264.1 (55 mm $\mathrm{dm}$ ), develop a subangular ventrolateral margin that separates the flanks from the slightly flattened venter (Fig. 57A). This specimen also shows the slight adult opening of the umbilicus (uw/dm $=0.15$ ) and the longitudinal groove on the umbilical wall. The entire specimen represents the body chamber, which is smooth except for four shallow constrictions on the last third of the volution. These begin on the flanks at some distance from the umbilicus and show a shallow lateral sinus, a pronounced angular ventrolateral salient, and a deep ventral sinus. Remains of the shell ornament are only visible in the umbilicus, where spiral lines and growth lines of equal strength occur.

Shell remains are very rare in this material. Specimens MB.C.13264.4 (50 mm dm) and MB.C.13258.1 $(46 \mathrm{~mm} \mathrm{dm})$ display traces of the ornament that are impressed on the steinkern. They show spiral lines on the
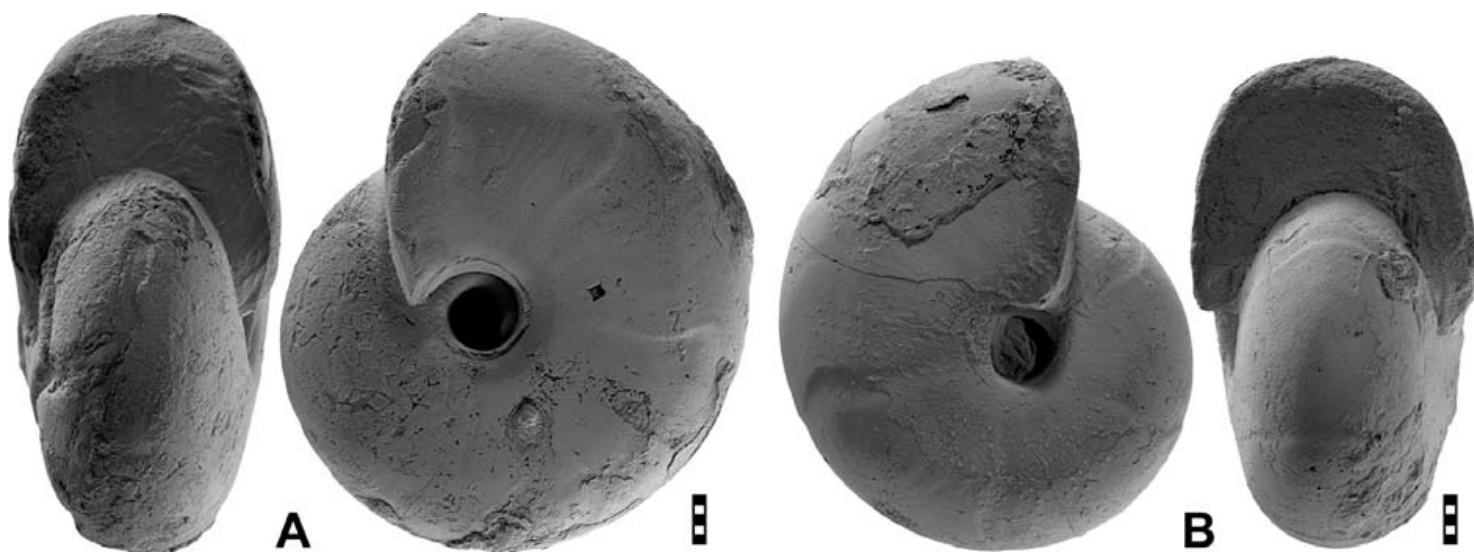

Figure 57. Sudeticeras splendens (Bisat, 1928). A. Specimen MB.C.13264.1 from locality Chebket el Hamra-P; $\times 1.0$. B. Specimen MB.C.13264.2 from locality Chebket el Hamra-P; $\times 1.0$. 

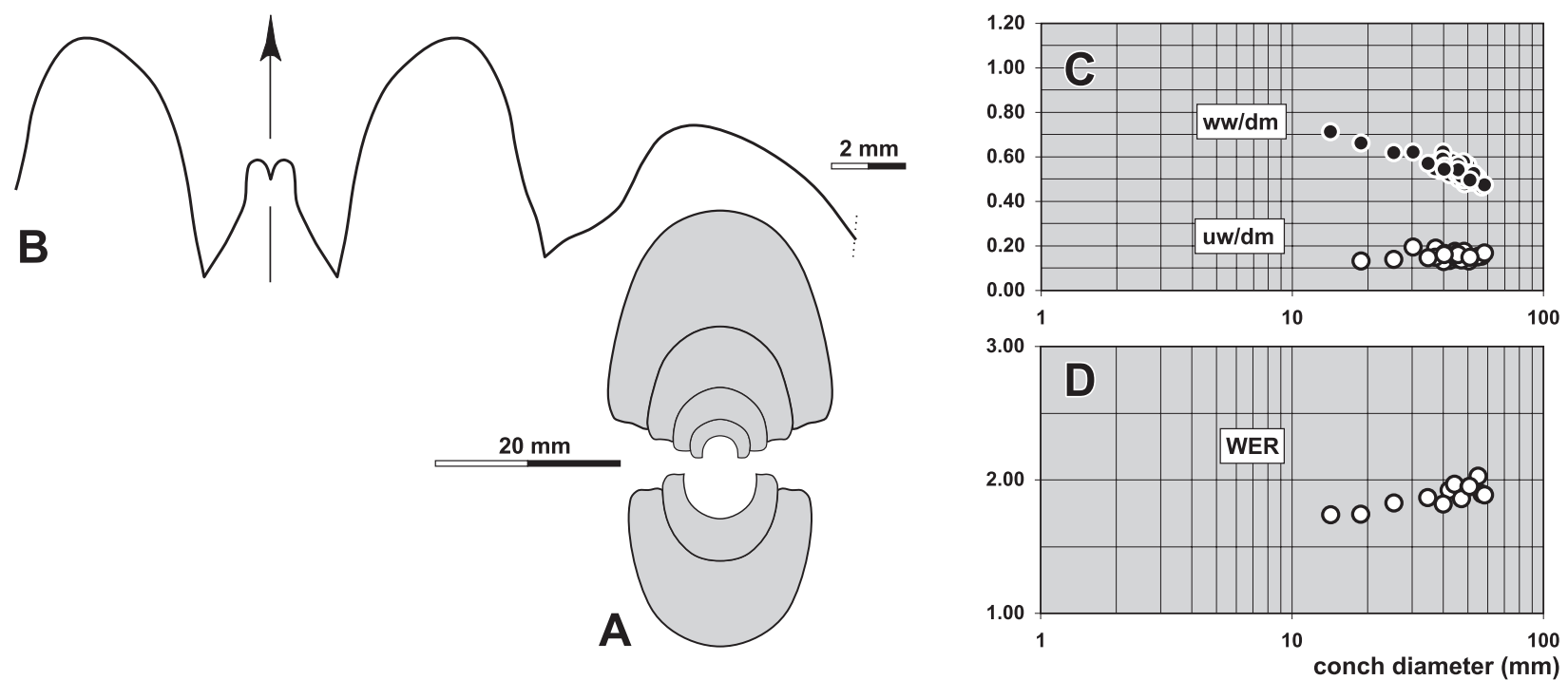

Figure 58. Sudeticeras splendens (Bisat, 1928). A. Cross section of specimen MB.C.13248.1 from locality Chebket el Hamra-K; $\times$ 1.0. B. Suture line of specimen MB.C.13264.3 from locality Chebket el Hamra-P, at $13 \mathrm{~mm} \mathrm{wh;} \times 4.0$. C, D. Ontogenetic development of the conch width index (ww/dm), umbilical width index (uw/dm) and whorl expansion rate (WER) of all available specimens.

venter and in the area of the ventrolateral projection; these spirals become weaker on the flanks and disappear in the midflank area. Specimen MB.C.13264.4 in particular exhibits the spiral lines do not follow an exact spiral course, but are frequently dislocated.

The suture line was drawn from specimen MB.C.13264.3 at a whorl height of $13 \mathrm{~mm}$ (corresponding to a conch diameter of $30 \mathrm{~mm}$ ). The rather wide external lobe renders it characteristic for Sudeticeras, whose incurved flanks strongly converge (Fig. 58B). The median saddle reaches exactly the half the height of the external lobe depth; its flanks are inwardly curved forming asymmetric prongs of the external lobe. The ventrolateral saddle is broadly rounded; the adventive lobe is less deep as the external lobe. It has a slightly curved ventrally and has a stronger curved dorsal flank.

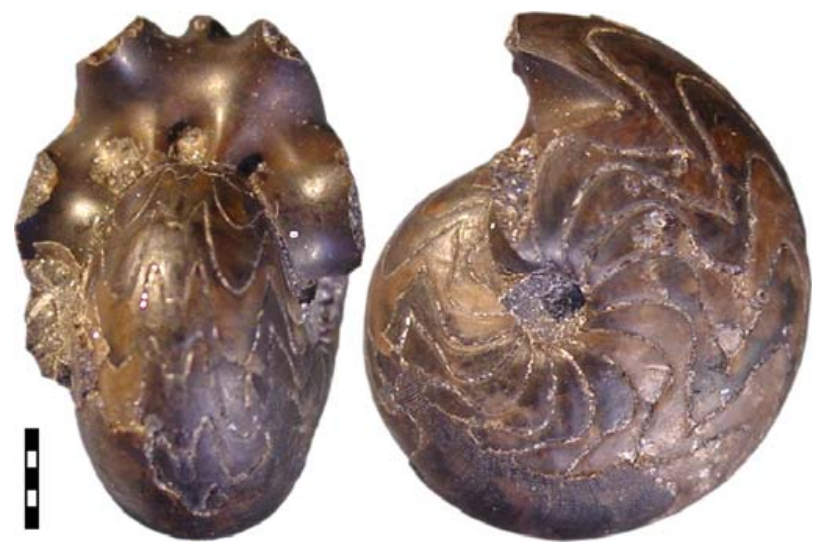

Figure 59. Sudeticeras splendens (Bisat, 1928), specimen NHM c38123 from Hilly Clough Farm near Barnoldswick, Lancashire (Moore Coll.); $\times 2.0$. This figure is available in colour online at museum-fossilrecord.wiley-vch.de
Discussion. Comparison of the British and Moroccan material is difficult because of different modes of preservation. The suture lines published by Moore (1950, pl. 3, figs 4,5 ) are too schematic to be diagnostic (the external lobe is drawn asymmetrically in nearly all the figures); however, his figure 4 shows that the ventrolateral saddle is narrowly rounded at $33 \mathrm{~mm}$ conch diameter and differs from the Moroccan specimen MB.C.13264.3, in which the saddle is rounded. The suture line of the beautifully preserved specimen NHM c38123 (Figs 59, 60) from Hilly Clough Farm near Barnoldswick has a rounded ventrolateral saddle. It also has a moderately wide external lobe $(0.65$ of the $E$ lobe depth; 1.30 of the adventive lobe) and a moderate median saddle ( 0.40 of the E lobe depth).

Sudeticeras splendens differs from most of the other species of the genus in its strong spiral ornament on the venter and ventrolateral shoulder. Only $S$. ordinatum Moore, 1950 is very similar; it is a stout form (ww/ $\mathrm{dm}=0.75$ at $25 \mathrm{~mm} \mathrm{dm}$ ) with spiral lines on venter and ventrolateral area. However, S. ordinatum also has spiral ornament on the flanks. The co-occurring $S$. horoni has a narrower umbilicus, a less well developed

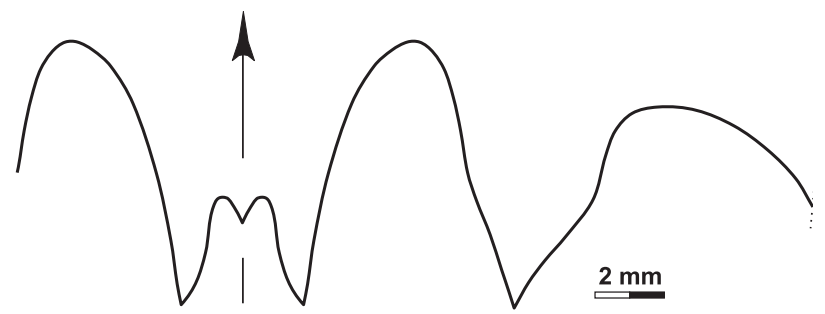

Figure 60. Sudeticeras splendens (Bisat, 1928), suture line of specimen NHM c38123 from Hilly Clough Farm near Barnoldswick, Lancashire (Moore Coll.), at $26.7 \mathrm{~mm} \mathrm{dm}, 17.2 \mathrm{~mm}$ ww, $13.3 \mathrm{~mm}$ wh; $\times 3.5$. 
ventrolateral angularity of the conch, and weaker spiral lines.

\section{Sudeticeras horoni $\mathbf{n}$. sp.}

Figures 61-63

Derivation of name. After O. Horon, one of the pioneers who investigated the geology of the Jerada Basin.

Holotype. Specimen MB.C.13212.1 (Korn \& Ebbighausen 2006 Coll.); illustrated in Figure 61C.

Type locality and horizon. Chebket el Hamra-E (Jerada Basin, NEMorocco); horizon CeH-4 (late Brigantian, Early Carboniferous).

Material. 163 sideritic specimens ranging from a conch diameter 21 to $76 \mathrm{~mm}$, from horizon CeH-4 at localities Chebket el Hamra-E, J, $\mathrm{O}, \mathrm{P}, \mathrm{Q}$, and R, of which many were collected as float material.

Diagnosis. Sudeticeras with thickly pachyconic conch at $10 \mathrm{~mm}$ diameter $(\mathrm{ww} / \mathrm{dm}=0.75-0.85)$, thickly discoidal conch at $30 \mathrm{~mm}$ diameter $(\mathrm{ww} / \mathrm{dm}=0.50-0.60)$, and discoidal conch at $50 \mathrm{~mm}$ diameter $(\mathrm{ww} / \mathrm{dm}=0.40-0.50)$. Umbilicus very narrow in all stages larger than $10 \mathrm{~mm} \mathrm{dm}$ (uw $/ \mathrm{dm}=0.05-0.12$ ), but opening slightly in the adult stage; umbilical margin broadly rounded, umbilical wall rounded. Ornamentation with strongly crenulated biconvex and rectiradiate growth-lines having a low dorsolateral projection and low ventrolateral projection; external sinus deep. Weak spiral lines mainly caused by crenulation of the growth lines; in the adult stage rather strong spirals in the ventrolateral area. Suture line with V-shaped, moderately wide external lobe $(0.80$ of the external lobe depth, 1.30 of the adventive lobe), and moderate median saddle ( 0.50 of the external lobe depth). Ventrolateral saddle broadly rounded, adventive lobe V-shaped with weakly sinuous flanks.

Description. The morphometric plots illustrate limited intraspecific variability (Figs 62F, G). A number of cross sections have been produced, but only three are suitable for a description of conch ontogeny. The best belongs to specimen MB.C.13246 (Fig. 62A), which displays the conch ontogeny between 1.4 and $51 \mathrm{~mm}$ $\mathrm{dm}$. The conch shape has a continuous trend toward become slender after a maximum of $w w / d m=0.96$ at $4.5 \mathrm{~mm}$ conch diameter. In the largest specimen of $76 \mathrm{~mm} \mathrm{dm}$, the ratio is at 0.42 . After a widely umbilicate juvenile stage (uw/dm $=0.34$ at $2.5 \mathrm{~mm} \mathrm{dm}$ ), the conch becomes involute with a very narrow umbilicus throughout ontogeny (uw/dm around 0.10 between 13 and $40 \mathrm{~mm} \mathrm{dm}$ ). Later stages show a slight increase of the ratio.

The partly crushed paratype MB.C.13260.1 $(68 \mathrm{~mm}$ $\mathrm{dm})$ displays the adult morphology $(\mathrm{ww} / \mathrm{dm}=0.44$;
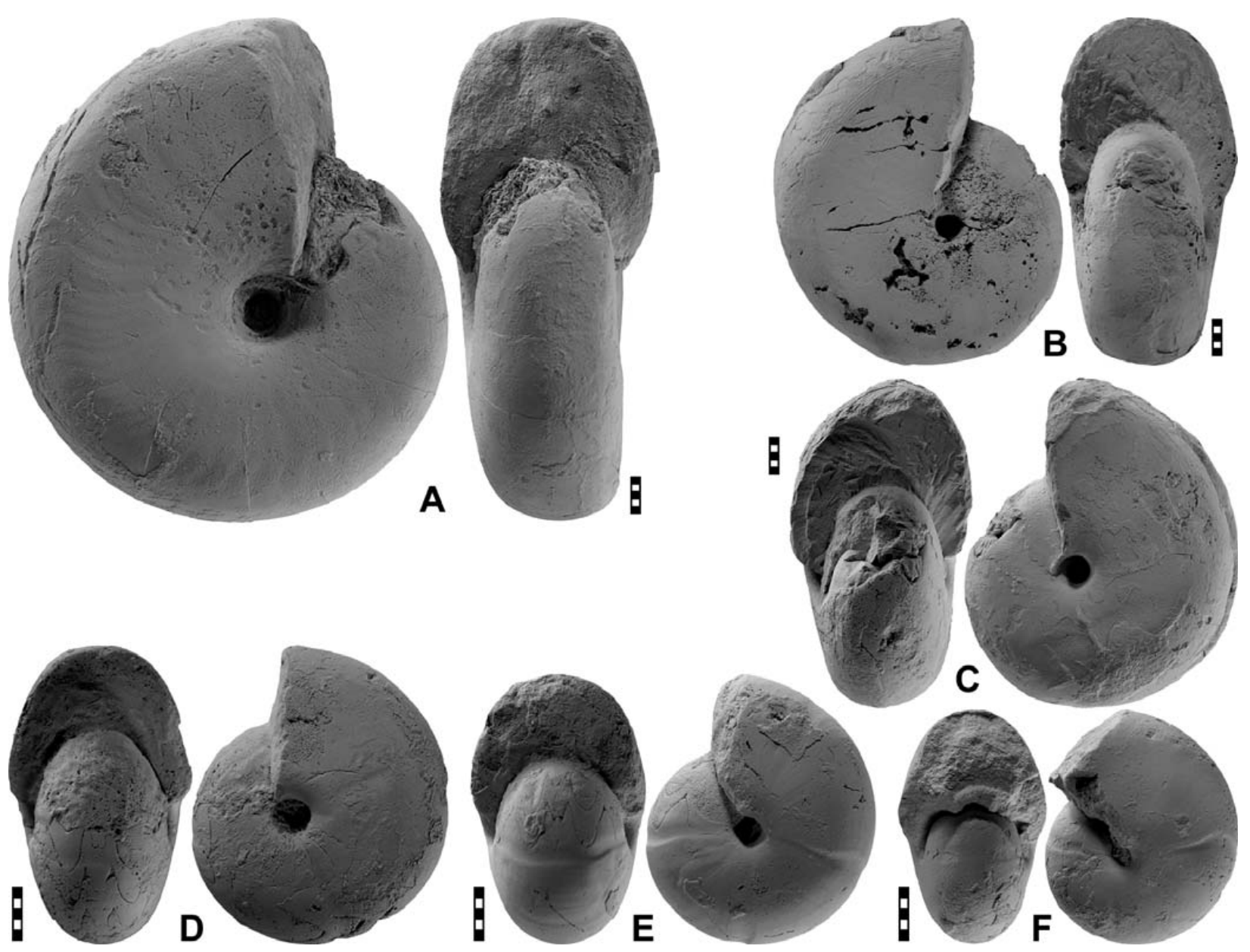

Figure 61. Sudeticeras horoni n. sp. A. Paratype MB.C.13260.1 from locality Chebket el Hamra-O; $\times 1.0$. B. Paratype MB.C.13212.2 from locality Chebket el Hamra-E. C. Holotype MB.C.13212.1 from locality Chebket el Hamra-E; $\times 1.0$. D. Paratype MB.C.13212.4 from locality Chebket el Hamra-E; $\times 1.5$. E. Paratype MB.C.13212.3 from locality Chebket el Hamra-E; $\times 1.5$. F. Specimen MB.C.13260.2 from locality Chebket el Hamra-O; $\times 1.5$. 


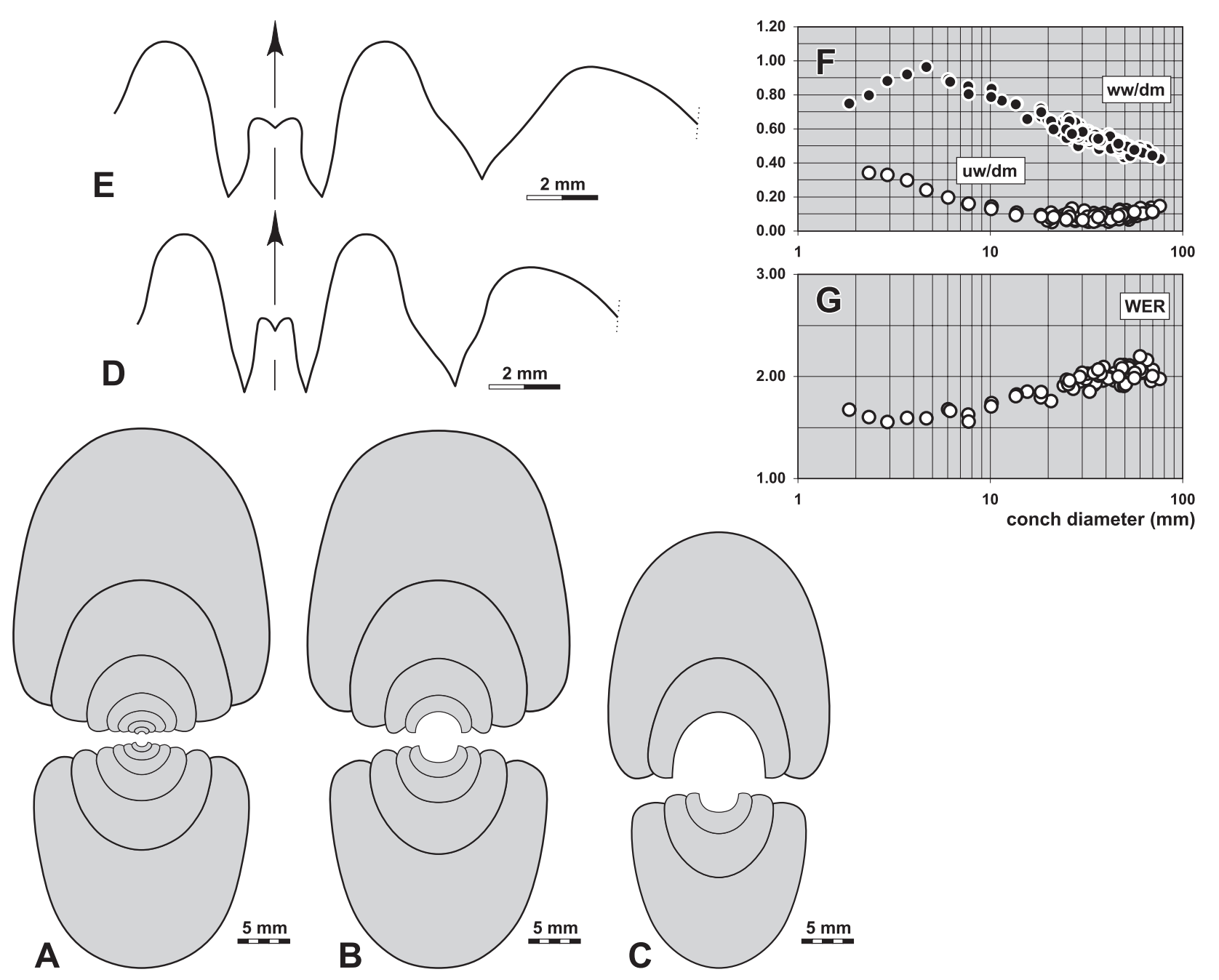

Figure 62. Sudeticeras horoni n. sp. A. Cross section of paratype MB.C.13246 from locality Chebket el Hamra-J; $\times 1.5$. B. Cross section of paratype MB.C.13266.1 from locality Chebket el Hamra-Q; $\times 1.5$. C. Cross section of paratype MB.C.13289.1 from Chebket el Hamra; $\times$ 1.5. D. Suture line of paratype MB.C.13212.3 from locality Chebket el Hamra-E, at $11.1 \mathrm{~mm} w w, 8.0 \mathrm{~mm}$ wh; $\times 5.0$. E. Suture line of paratype MB.C.13212.4 from locality Chebket el Hamra-E, at $12.7 \mathrm{~mm}$ ww, $8.3 \mathrm{~mm}$ wh; $\times 5.0$. F, G. Ontogenetic development of the conch width index (ww/dm), umbilical width index (uw/dm) and whorl expansion rate (WER) of all available specimens.

$\mathrm{uw} / \mathrm{dm}=0.14 ; \quad \mathrm{WER}=1.96)$ in which, after about $54 \mathrm{~mm} \mathrm{dm}$, slowly converging flanks stand almost parallel, being separated from the slightly flattened venter by a subangular margin (Fig. 61A). The whorl is widest at the inner third of the flank; the umbilical margin is broadly rounded and allows the flank to continue slowly into the rounded umbilical wall. Almost the entire last whorl of the specimen belongs to the body chamber, which is smooth except for impressions of a rhythmical strengthening of the growth lines particular on the last half volution. This pattern is particularly well-developed on the outer flank.

A similar conch geometry is displayed by paratype MB.C.13212.2 with $47 \mathrm{~mm} \mathrm{dm}(\mathrm{ww} / \mathrm{dm}=0.49$; uw/ $\mathrm{dm}=0.09$; WER $=1.99$ ). This specimen is remarkable for its shell remains, which show a development from strongly crenulated growth lines, which cause a fine spiral ornament at the beginning of the last volution, towards a rather strong spiral ornamentation half a vo- lution later (Fig. 61B). This consists of sharp, irregularly arranged spirals, which are strongest on the venter and ventrolateral shoulder. These spirals differ in their strength and have the same width as their interspaces.

The smaller, somewhat distorted but otherwise rather well-preserved holotype MB.C.13212.1 (44 mm dm) still displays the stage in which flanks and venter are broadly rounded (Fig. 61C). The flanks are widest near the very narrow umbilicus ( $\mathrm{uw} / \mathrm{dm}=0.09$ ). The specimen displays beautifully preserved shell ornament, which is composed of slightly biconvex, strongly crenulated growth lines with a very low dorsolateral projection, a low ventrolateral projection, and a deep ventral sinus. The strong crenulation causes a delicate spiral ornament particularly in the umbilical area, which in association with the growth lines, forms a spider-web like pattern.

Shell remains are also preserved on the small paratype MB.C.13260.2 (20 $\mathrm{mm} \mathrm{dm})$. The growth lines are 


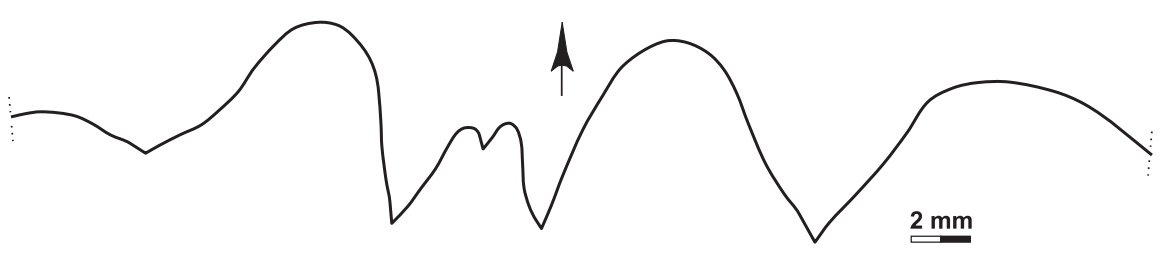

Figure 63. Sudeticeras horoni $\mathrm{n}$. sp. Suture line of the pathologic paratype MB.C.13260.3 from locality Chebket el Hamra-O, at $19.4 \mathrm{~mm}$ ww, $15.5 \mathrm{~mm}$ wh; $\times 5.0$.

delicate in this stage; they are crenulated and form spirals only in a narrow zone around the umbilicus (Fig. 61F). The growth lines run with equally high lateral projections and a low ventral sinus across flanks and venter. A few irregularly arranged shallow constrictions can be seen on the steinkern.

Suture lines can be studied in three specimens. The first of these, MB.C.13260.3, is a pathologic specimen in which the external lobe of the strikingly asymmetric suture line does not have a midventral position (Fig. 63). The adventive lobe is conspicuously deformed on one side, being much lower than in normal suture lines.

The suture line of specimen MB.C.13212.4 (at $12.7 \mathrm{~mm} \mathrm{ww}$, corresponding to $20 \mathrm{~mm}$ conch diameter) has a broad V-shaped external lobe with moderately strong diverging flanks (Fig. 62E). The median saddle is raised to half the height of the external lobe and subdivides the external lobe into slightly asymmetric prongs. The ventrolateral saddle is also asymmetric and rounded; it is followed by the V-shaped adventive lobe with slightly curved flanks. The suture line of the smaller specimen MB.C.13212.3 is similar but has a narrower external lobe (Fig. 62D).

Discussion. Sudeticeras horoni differs from most species of Sudeticeras in the strong spiral ornament, particularly on the venter and ventrolateral shoulder. Of these species, S. ordinatum has a stouter conch (ww/ $\mathrm{dm}=0.66$ at $38 \mathrm{~mm} \mathrm{dm}$, in contrast to $0.50-0.55$ in S. horoni).

S. splendens possesses a similar ornament but has a wider umbilicus (uw $/ \mathrm{dm}=$ less than 0.10 between 20 and $60 \mathrm{~mm} \mathrm{dm}$ in $S$. horoni, but $0.12-0.16$ in S. splendens) and lacks steinkern constrictions in the larger growth stage. A further criterion to separate the two species is the shape of the umbilical wall, being simply rounded in $S$.horoni but sinuous in cross section in S. splendens.

Family Neoglyphioceratidae Plummer \& Scott, 1937

\section{Neoglyphioceras Brüning, 1923}

Type species. Goniatites spiralis Phillips, 1841.

Discussion. Neoglyphioceras is a species-rich genus, of which about 25 species have been described (AMMON database; Korn \& Ilg 2007). The genus is almost globally distributed, with the various species having been described from North America (4 species), Northwest and Central Europe (3 species), the South Urals and Central Asia (5 species), Novaya Zemlya (3 species), Iran (1 species), the Far East (2 species), and China (7 species).

The European species of Neoglyphioceras can be grouped as follows:

A - species with a slender conch $(\mathrm{ww} / \mathrm{dm}=$ less than 0.60):

N. spirale (Phillips, 1841): with 55-60 spiral lines;

N. suerlandense Korn, 1988: with 30 spiral lines.

B - species with a stout conch $\quad(\mathrm{ww} / \mathrm{dm}=$ more than 0.70):

N. orculum Korn, 1988: with 40 spiral lines.

\section{Neoglyphioceras spirale (Phillips, 1841)}

Figures 64-65

1841 Goniatites spiralis Phillips, p. 121, pl. 50, fig. 233.

1937 Goniatites spiralis. - Ruprecht, p. 266, pl. 9, figs 8-9.

1955 Neoglyphioceras spirale. - Bisat, p. 15, pl. A, figs 1-9.

1958 Neoglyphioceras spirale. - Moore \& Hodson, p. 101, pl. 8, fig. 5.

1988 Neoglyphioceras spirale. - Korn, p. 157, pl. 52, figs 1-7.

1992 Neoglyphioceras spirale. - Gischler \& Korn, p. 283, textfigs 4J, $5 \mathrm{D}, 6 \mathrm{I}$.

1997 Neoglyphioceras spirale. - Korn, p. 63, pl. 8, figs 5-6.

Neotype. Specimen NHM c1640 (Lee Coll.); figured by Bisat (1955, pl. A, fig. 1).

Type locality and horizon. Bampton (Devonshire, Great Britain); probably P1d Subzone of the British zonation (Late Viséan).

Material. 16 limonitic steinkern specimens at conch diameters ranging between 12.5 to $18 \mathrm{~mm}$ from horizon $\mathrm{CeH}-2$ at localities Chebket el Hamra-E, F, I, and T.

Diagnosis. Neoglyphioceras with thickly discoidal conch at $12 \mathrm{~mm}$ diameter $(\mathrm{ww} / \mathrm{dm}=0.55-0.60)$ and discoidal conch at $20 \mathrm{~mm}$ diameter $(\mathrm{ww} / \mathrm{dm}=0.50)$. Umbilicus narrow in juveniles and very narrow in adults (uw/dm less than 0.10 at $20 \mathrm{~mm} \mathrm{dm}$ ). Ornamentation with 55-60 spiral lines. Strong constrictions of the internal mould. Suture line with V-shaped narrow external lobe having widely diverging flanks; ventrolateral saddle wide, parabolic; adventive lobe Vshaped.

Description. Most of the specimens are fragmentary or otherwise poorly preserved, and hence a complete description of conch and ornament details is not possible. The cross section MB.C.13226.2 does not show the innermost whorls, but permits the study of the growth interval from 3 to $17 \mathrm{~mm}$ diameter (Fig. 65A). 

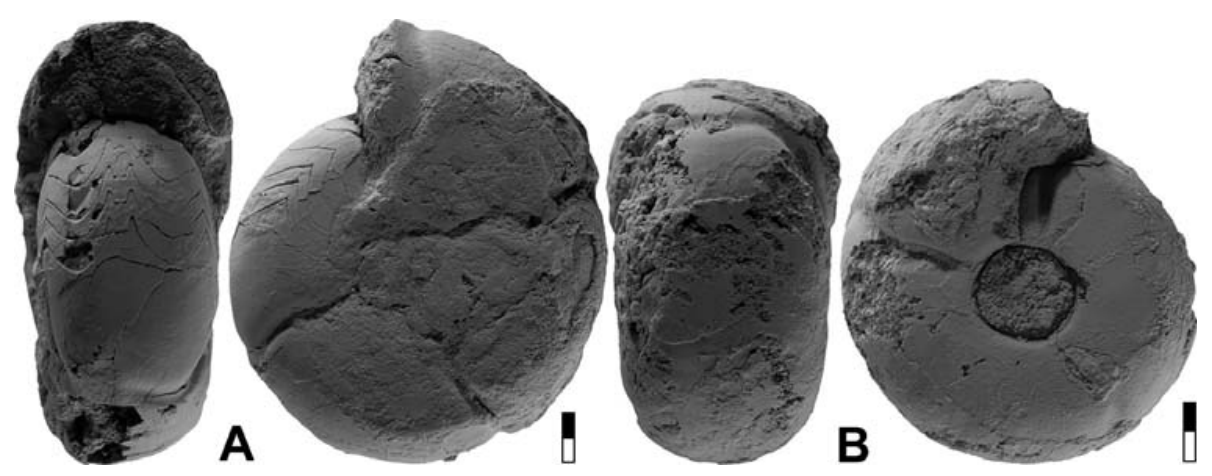

Figure 64. Neoglyphioceras spirale (Phillips, 1841). A. Specimen MB.C.13242.1 from locality Chebket el Hamra-I; $\times 2.5$. B. Specimen MB.C.13226.1 from locality Chebket el Hamra-F; $\times 3.0$.
A second not figured cross section differs in some conch parameters, with specimen MB.C.13226.2 being the wider umbilicate form (uw $/ \mathrm{dm}=0.19$ at $16 \mathrm{~mm}$ $\mathrm{dm})$ with lower aperture $(\mathrm{WER}=1.47$ at $16 \mathrm{~mm}$ $\mathrm{dm})$.

The larger of the two figured specimens (MB.C.13242.1, $18 \mathrm{~mm} \mathrm{dm}$; Fig. 64A) is partly covered by limonite matrix that obscures the umbilicus; it is a discoidal conch $(\mathrm{ww} / \mathrm{dm}=0.50)$ with a low aperture $(\mathrm{WER}=1.65)$. It has four deep constrictions on the last volution, arranged in distances slightly below $90^{\circ}$, and running with low dorsolateral and higher ventrolateral projection as well as a shallow ventral sinus across flanks and venter. It is estimated that 55-60 spiral lines, which are impressed on the internal mould, exist on the flanks and venter.

The smaller and better preserved specimen MB.C.13226.1 (Fig. 64B) has $12.5 \mathrm{~mm}$ diameter and is thickly discoidal $(\mathrm{ww} / \mathrm{dm}=0.58)$ with a narrow umbilicus (uw/dm $=0.27$ ). It possesses three irregularly distributed constrictions on the steinkern, having a concave course on the flanks, turning forward to create a distinct ventrolateral projection, and form a shallow ventral sinus. In this specimen, spiral lines are barely visible on the internal mould; therefore their number cannot be estimated.

The suture line of specimen MB.C.13242.1 (7 mm whorl width) is remarkable because of its low amplitude, expressed in very low and wide lobes and saddles (Fig. 65B). The external lobe and the adventive lobe are almost equally wide, separated by a much wider parabolic and almost symmetric ventrolateral saddle.

Discussion. It is easy to separate $N$. spirale from the other species of Neoglyphioceras by its suture line with low amplitude and its very wide ventrolateral saddle. Only N. suerlandense Korn, 1988, is similar in this respect but this species has much fewer spiral lines (about 30) than $N$. spirale (about 55-60).

\section{Lusitanites Ruzhencev \& Bogoslovskaya, 1971}

Type species. Goniatites subcircularis Miller, 1889.

Discussion. Six species of Lusitanites have been described (AMMON database; Korn \& Ilg 2007). The genus is widely distributed from the western United States across North Africa, Iberia, Northwest and Central Europe to the South Urals and Central Asia.

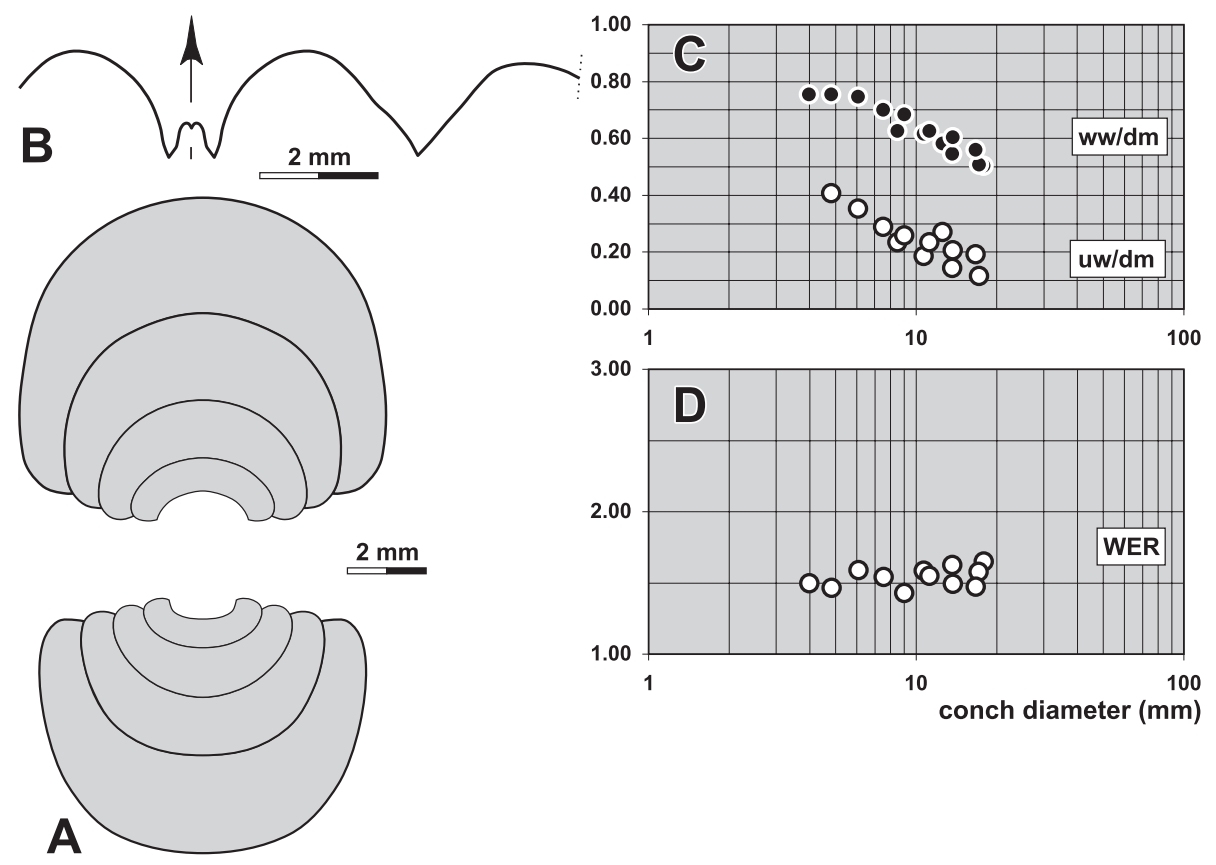

Figure 65. Neoglyphioceras spirale (Phillips, 1841). A. Cross section of specimen MB.C.13226.2 from locality Chebket el Hamra-I; $\times 2.5$. B. Suture line of specimen MB.C.13242.1 from locality Chebket el Hamra-I, at $7.1 \mathrm{~mm}$ ww, $5.2 \mathrm{~mm}$ wh; $\times 5.0$. C, D. Ontogenetic development of the conch width index (ww/dm), umbilical width index (uw/dm) and whorl expansion rate (WER) of all available specimens. 
The species of Lusitanites can be grouped as follows:

A - species with a moderate umbilicus $(\mathrm{uw} / \mathrm{dm}=$ more than 0.12):

L. subcircularis (Miller, 1889): with 30 spiral lines and numerous constrictions across flanks and venter;

L. clitheroensis Korn, 1988: with 35 spiral lines and a few constrictions across flanks and venter.

B - species with a very narrow umbilicus (uw/ $\mathrm{dm}=$ less than 0.12):

L. concavus Ruzhencev \& Bogoslovskaya, 1971: with 35 spiral lines and a few very short constrictions;

L. multicavus Ruzhencev \& Bogoslovskaya, 1971: with 40 spiral lines and numerous short constrictions;

L. zousfanensis (Dollé, 1912): with 40 spiral lines and a few short constrictions;

L. circularis Korn, 1988: with 50 spiral lines and numerous constrictions across flanks and venter.

\section{Lusitanites circularis Korn, 1988}

Figures 66-67

1925 Glyphioceras subcircularis subcircularis. - Schmidt, p. 573 , pl. 21, fig. 12, pl. 24, figs 1, 2.

1933 Glyphioceras subcircularis subcircularis. - Kobold, p. 500, pl. 22, figs 18-21.

1937 Goniatites subcircularis subcircularis. - Ruprecht, p. 263, pl. 9, figs $1,2$.

1988 Lusitanites circularis Korn, p. 162, pl.56, figs 1-10, pl. 57, figs 1-6.

Holotype. Specimen GÖT480-70 (H. Schmidt Coll.); figured by Schmidt (1925, pl. 24, fig. 1) and Korn (1988, pl. 56, figs 1-3).

Type locality and horizon. Oelinghausen (Rhenish Mountains, Germany); probably Lusitanoceras poststriatum Zone (Late Viséan).

Material. Seven limonitic or phosphatic steinkern specimens ranging from 17 to $18 \mathrm{~mm}$ in conch diameter, from horizon $\mathrm{CeH}-5$ at localities Chebket el Hamra-D, K, and P.

Diagnosis. Lusitanites with thickly discoidal conch at $10 \mathrm{~mm}$ diameter $(\mathrm{ww} / \mathrm{dm}=0.50-0.55)$ and discoidal to thinly pachyconic conch at $20 \mathrm{~mm}$ diameter $(\mathrm{ww} / \mathrm{dm}=0.40-0.45)$. Umbilicus very narrow in all stages larger than $10 \mathrm{~mm} \mathrm{dm}(\mathrm{uw} / \mathrm{dm}=0.08-0.15)$. Ornamentation of approximately 50 spiral lines. Three to five strong constrictions on the internal mould, extending in a markedly sinuous manner with flat- tened ventral projection. Suture line with V-shaped narrow external lobe and widely diverging flanks; ventrolateral saddle wide, parabolic; adventive lobe V-shaped

Description. The largest of the available specimens MB.C.13262.1 (21 $\mathrm{mm} \mathrm{dm})$ has a crushed body chamber, but the phragmocone is rather well preserved (Fig. 66A). It shows five irregularly arranged strongly curved steinkern constrictions and 55-60 fine spiral lines, which are visible as traces on the steinkern.

Specimen MB.C.13208.1 is better preserved (Fig. 66B), being an almost fully septate individual of $17.5 \mathrm{~mm} \mathrm{dm}$. It is discoidal $(\mathrm{ww} / \mathrm{dm}=0.43)$ with a very narrow umbilicus $(\mathrm{uw} / \mathrm{dm}=0.14)$. The steinkern has four constrictions, arranged in distances of a little more than $90^{\circ}$. They are deepest on the outer flank where they form a shallow lateral sinus, and almost disappear at the transitions to the venter where they turn forward to form a rather narrow ventral projection. About 55 spiral lines, preserved as traces on the steinkern, can be counted from umbilicus to umbilicus. They are best visible in the ventrolateral area and on the venter.

Suture lines of the three better preserved specimens show, in the same growth stage, conspicuous variation (Fig. 67). The suture line of the largest specimen MB.C.13262.1 (7.2 $\mathrm{mm} \mathrm{ww)} \mathrm{is} \mathrm{remarkable} \mathrm{because} \mathrm{of}$ its wide external lobe with strongly diverging, slightly sinuous flanks (Fig. 67C). The median saddle reaches slightly more than 0.30 of the E lobe depth; it produces two small asymmetric prongs with a hook-like base. On the ventrolateral shoulder a wide and parabolic ventrolateral saddle follows that continues into the rather small, V-shaped adventive lobe. This suture line is the last one of a series of six rather closely spaced septa, in which the external lobe widens markedly; most probably it represents an adult modification.

The suture lines of the two specimens MB.C.13262.2 and MB.C.13208.1 (both drawn at $16.5 \mathrm{~mm} \mathrm{dm}$ ) differ from the above, but resemble each other to some degree (Figs 67A-B). The external lobe is rather narrow and $\mathrm{V}$-shaped in both, the ventrolateral saddle is parabolic, and the adventive lobe is small and V-shaped. Differences can be seen in the median saddle, which is much higher in specimen MB.C.13262.2.
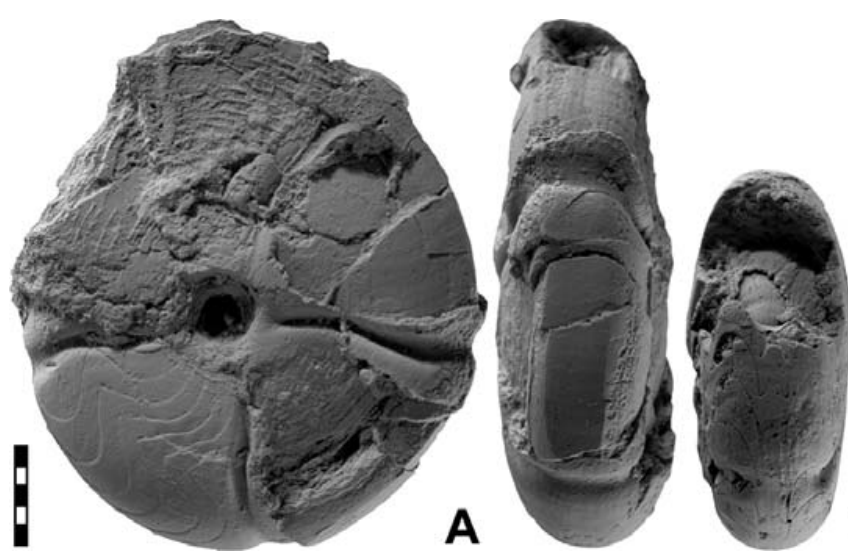

Figure 66. Lusitanites circularis Korn, 1988. A. Specimen MB.C.13262.1 from locality Chebket el Hamra-P; $\times 2.0$. B. Specimen MB.C.13208.1 from locality Chebket el Hamra-D; $\times 2.0$. 


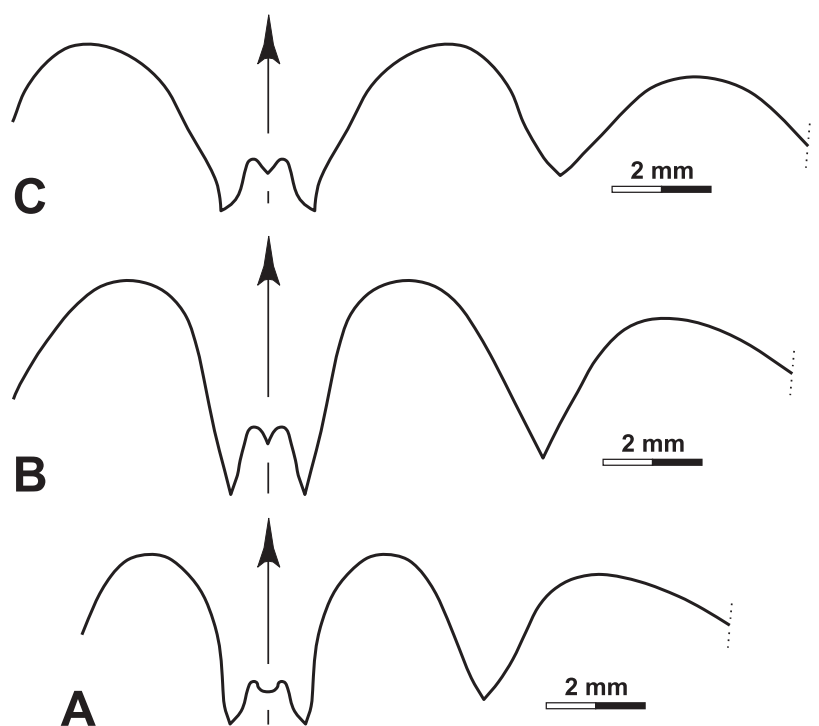

Figure 67. Lusitanites circularis Korn, 1988 A. Suture line of specimen MB.C.13208.1 from locality Chebket el Hamra-D, at $16.5 \mathrm{~mm} \mathrm{dm}, 7.7 \mathrm{~mm} w w, 7.7 \mathrm{~mm}$ wh; $\times 5.0$. B. Suture line of specimen MB.C.13262.2 from locality Chebket el Hamra-P, at $16.8 \mathrm{~mm} \mathrm{dm}, 8.0 \mathrm{~mm}$ ww, $7.8 \mathrm{~mm}$ wh; $\times 5.0$. C. Suture line of specimen MB.C.13262.1 from locality Chebket el Hamra-P, at $7.2 \mathrm{~mm}$ ww, $9.4 \mathrm{~mm}$ wh; $\times 5.0$.

Discussion. The material from Chebket el Hamra is not particularly well-preserved, but can be attributed to the Rhenish species because of its very narrow umbilicus (wider than in L. clitheroensis) and high number of spiral lines (55-60 in contrast to 35 in L. clitheroensis). This high number of spiral lines allows rather clear separation from the other species of Lusitanites.

Family Ferganoceratidae Ruzhencev, 1960

\section{Ferganoceras Librovitch, 1957}

Type species. Ferganoceras elegans Librovitch, 1957.

Discussion. Ferganoceras is a genus that is known from localities in Central Asia, the South Urals (Ruzhencev \& Bogoslovskaya 1971), North Africa (Pareyn 1961; Klug et al. 2006), southern France (Delépine 1935; Korn \& Feist 2007) and Arkansas (Malinky \& Mapes 1982). The genus was so far not known from any North Variscan occurrences.

\section{Ferganoceras sp.}

Figure 68

Material. One whorl fragment from horizon CeH-5 of locality Chebket el Hamra-P.

Description. The only known specimen MB.C.13263 of this species is a whorl fragment of an individual having a conch diameter of $20 \mathrm{~mm}$ (Fig. 68). It is poorly preserved but shows all characters typical for the genus Ferganoceras, i.e. the slightly flattened venter that is bordered by a narrow but rather deep ventrolateral fur-
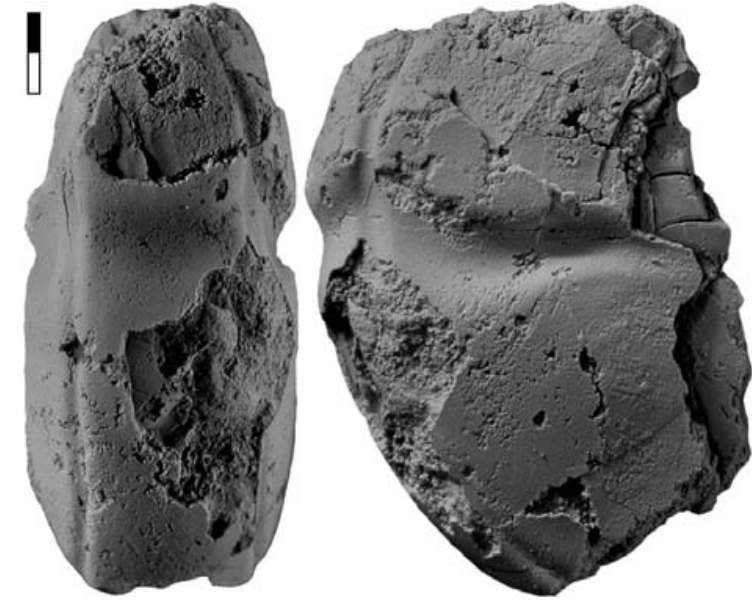

Figure 68. Ferganoceras sp., specimen MB.C.13263 from locality Chebket el Hamra-P; $\times 4.0$.

row. The flanks are also flattened and stand almost parallel. The whorl fragment possesses a deep constriction following a biconvex course; it shows a rather wide dorsolateral projection, a shallow lateral projection on the outer flank, a high ventrolateral projection at the ventrolateral furrow, and a semicircular ventral sinus. A weak indication of fine spiral lines is visible on the flanks.

Order Prolecanitida Hyatt, 1884

Suborder Prolecanitina Hyatt, 1884

Superfamily Prolecanitoidea Hyatt, 1884

Family Daraelitidae Tchernow, 1907

\section{Praedaraelites Schindewolf, 1934}

Type species. Daraelites culmiensis Kobold, 1933.

Discussion. Twenty-one species of Praedaraelites have been described thus far (AMMON database; Korn \& Ilg 2007), and fourteen of these alone from occurrences in China. Most of the species are not well characterised and some of these may be treated synonyms. The genus is widely distributed, but very rare in the western United States. It is restricted to distinct stratigraphic horizons in North Africa, Iberia, Northwest and Central Europe and more common in the South Urals and North China. Only one species is known from Central and North-western Europe.

\section{Praedaraelites culmiensis (Kobold, 1933)}

Figures 69-70

1933 Daraelites culmiensis Kobold, p. 506, pl. 23, figs 45-48. 1952 Epicanites bowlandensis Moore, p. 73, pl. 7, fig. 3, textfig. 4. 1988 Praedaraelites culmiensis. - Korn, p. 33, pl. 1, figs 1-4. 1997 Praedaraelites culmiensis. - Korn, p. 36, pl. 1, fig. 11, textfig. 21.

Lectotype. The specimen figured by Kobold (1933, pl. 23, fig. 6).

Type locality and horizon. Steigertal near Lautenthal (Harz); 'III $\gamma 1$ ' of Kobold (1933) = Neoglyphioceras spirale Zone (Late Viséan). 


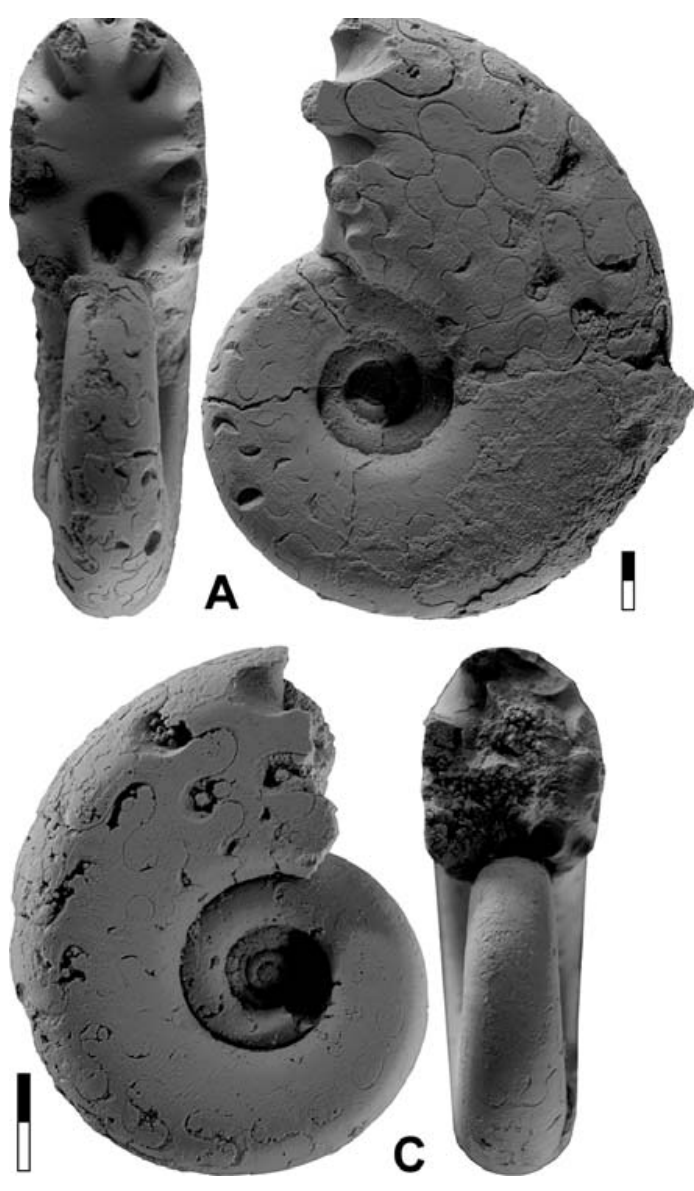

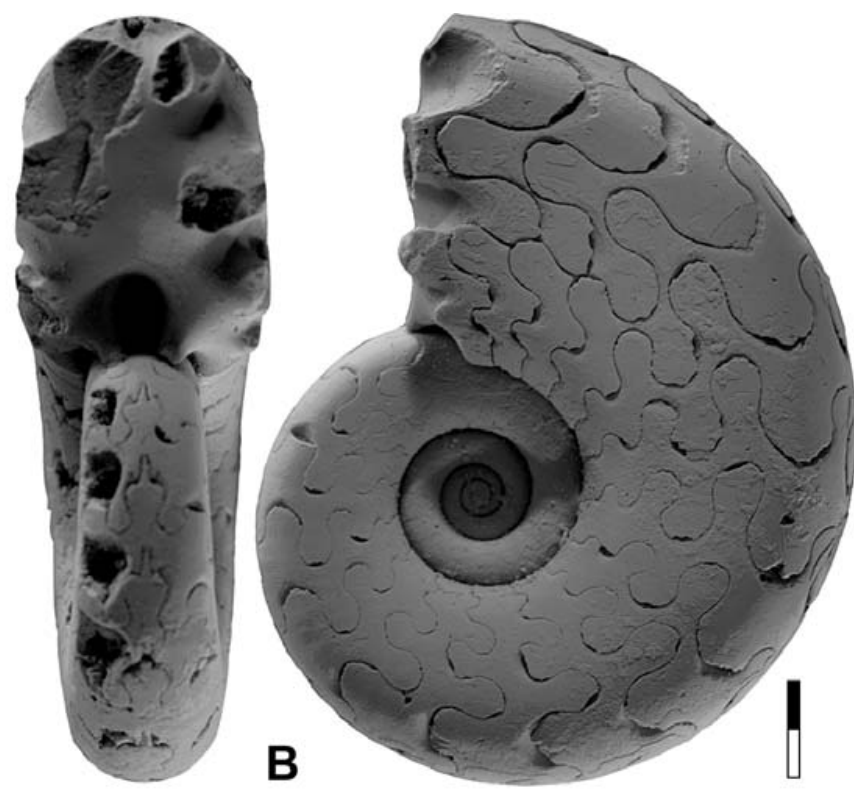

Figure 69. Praedaraelites culmiensis (Kobold, 1933). A. Specimen MB.C.13231.1 from locality Chebket el Hamra-G; $\times 3.0$. B. Specimen MB.C.13227.1 from locality Chebket el Hamra-F; $\times 5.0$. C. Specimen MB.C.13227.2 from locality Chebket el Hamra-F; $\times 5.0$.
Material. 38 limonitic steinkern specimens ranging from 10 to $22 \mathrm{~mm}$ in conch diameter from horizon $\mathrm{CeH}-2$ at localities Chebket el Hamra-E, F, G, I, and an unspecified locality.

Diagnosis. Praedaraelites with thinly discoidal conch (ww/dm $0.30-$ 0.35 ) in all growth stages; umbilicus moderately wide in juveniles and later becoming narrow (uw/dm 0.35 at $10 \mathrm{~mm} \mathrm{dm}, 0.25-0.30$ at $20 \mathrm{~mm} \mathrm{dm}$ ). Whorl cross section compressed, flanks and venter rounded. Shell almost smooth with very fine growth lines. Suture line with strongly pouched external lobe, asymmetric and serrated adventive lobe, barely serrated first lateral lobe, and tongue-shaped second lateral lobe.

Description. The material exhibits only minor intraspecific variability and only little ontogenetic change. The trait that best shows the visible ontogenetic modification is the apertural height, which, in the sectioned specimen MB.C.13227.3 causes the whorl to expand from 2.25 up to $4 \mathrm{~mm}$ diameter, but thereafter increases to 2.70 at $21 \mathrm{~mm} \mathrm{dm} \mathrm{(Fig.} \mathrm{70G).} \mathrm{The} \mathrm{whorl} \mathrm{width/}$ conch diameter ratio is stable around 0.40 up to $8 \mathrm{~mm}$ $\mathrm{dm}$ and then is reduced to 0.33 . The cross section of the slightly embracing whorls is almost circular up to $8 \mathrm{~mm}$ conch diameter and becomes then laterally compressed (Fig. 70A).

The largest specimens MB.C.13295 and MB.C.13231.1 (Fig. 69A) exceed $20 \mathrm{~mm}$ in diameter and are thinly discoidal $(\mathrm{ww} / \mathrm{dm}=0.30)$ with a narrow umbilicus (uw $/ \mathrm{dm}=0.27$ ). These specimens show slightly flattened flanks, which are clearly bordered against the rounded venter and the flat, oblique umbili- cal wall. Smaller specimens such as MB.C.13227.1 $(15 \mathrm{~mm} \mathrm{dm})$ and MB.C.13227.2 (10 $\mathrm{mm} \mathrm{dm})$ are similar in general morphology but show more regularly rounded flanks (Figs 69B, C).

The suture lines of different specimens exhibit some variability, particularly compared to the degree of serration of the adventive lobe (Figs 70B-D). The external lobe has the same shape in the three specimens MB.C.13243.1, MB.C.13227.4, and MB.C.13295 (all three with $18-19 \mathrm{~mm}$ conch diameter) and is strongly pouched in the lower two thirds. An inflated saddle and then the asymmetric adventive lobe follow on the ventrolateral shoulder. This is serrated with only two little notches (specimen MB.C.13243.1), three notches (specimen MB.C.13227.4), or more conspicuously serrated with several denticles of different size (specimen MB.C.13295). Two further, rounded lobes are located on the flank. The first shows an incipient beginning of serration. A small lobe occupies the umbilical margin.

Discussion. Praedaraelites culmiensis is a widely distributed species in the northern Variscides; it is known from the Harz and Rhenish Mountains of Germany, North England, Ireland, and South-western Portugal. All occurrences are obviously time equivalents, making the species a valuable index for the Late Viséan sediments.

Clear separation from other species of the genus is problematic because of the poor descriptions of many 


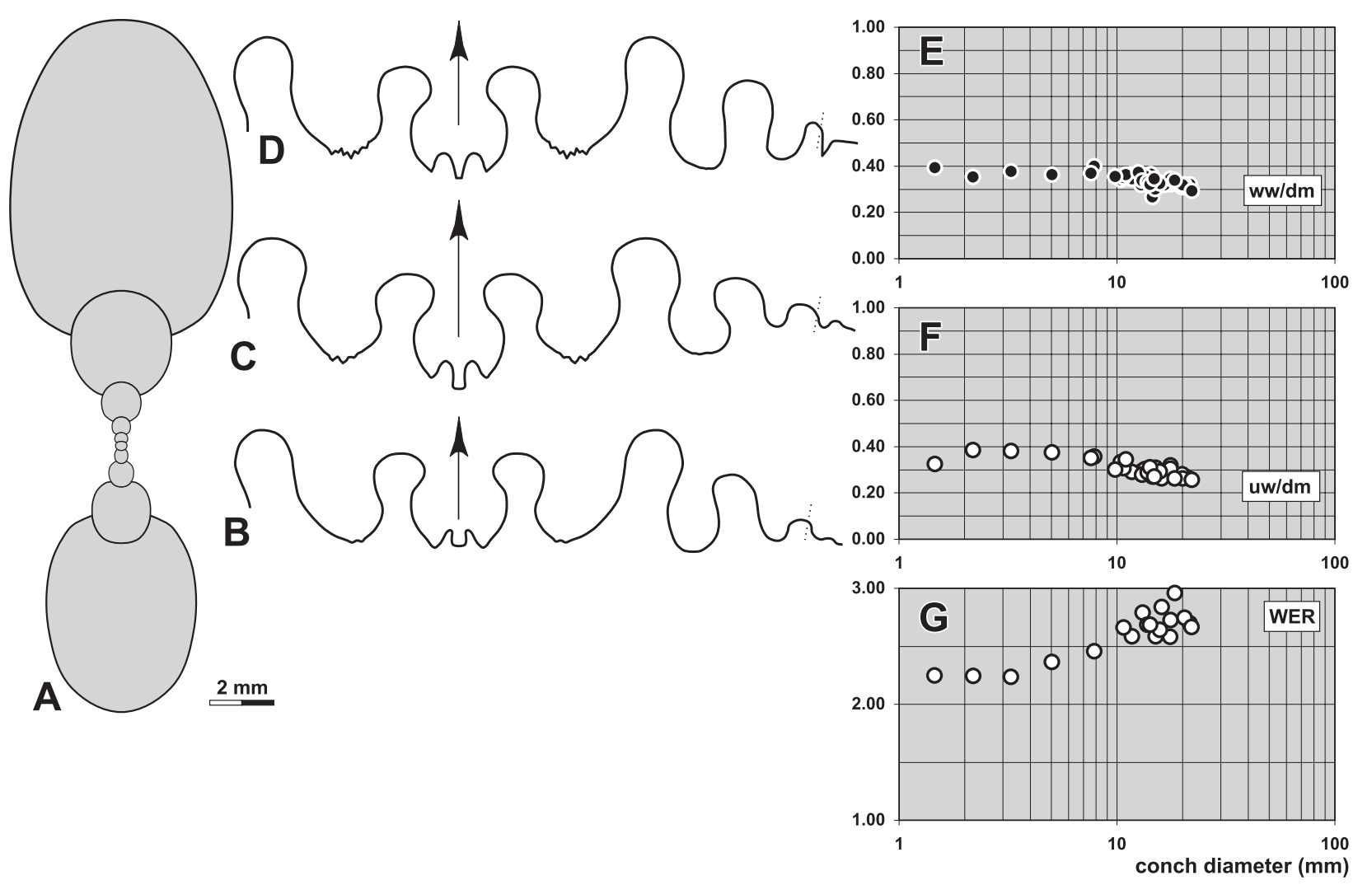

Figure 70. Praedaraelites culmiensis (Kobold, 1933). A. Cross section of specimen MB.C.13227.3 from locality Chebket el Hamra-F; $\times$ 4.0. B. Suture line of specimen MB.C.13243.1 from locality Chebket el Hamra-I, at $5.4 \mathrm{~mm}$ ww, $7.5 \mathrm{~mm}$ wh; $\times 5.0$. C. Suture line of specimen MB.C.13227.4 from locality Chebket el Hamra-F, $6.2 \mathrm{~mm}$ ww, $9.0 \mathrm{~mm}$ wh; $\times 5.0$. D. Suture line of specimen MB.C.13295 from locality Chebket el Hamra-X, at $19.0 \mathrm{~mm} \mathrm{dm}, 6.4 \mathrm{~mm}$ ww, $9.1 \mathrm{~mm}$ wh; $\times 5.0$. E-G. Ontogenetic development of the conch width index (ww/dm), umbilical width index (uw/dm) and whorl expansion rate (WER) of all available specimens.

specimens. Serration of the lobes is less well developed than in the well-known latest Viséan to earliest Serpukhovian species P. aktubensis Ruzhencev, 1949.

Superfamily Medlicottioidea Karpinsky, 1889 Family Pronoritidae Frech, 1901

\section{Pronorites Mojsisovics, 1882}

Type species. Goniatites cyclolobus Phillips, 1836.

Discussion. Eight species of Pronorites are listed in the AMMON database (Korn \& Ilg 2007). The genus has a distribution from the western United States across North Africa, Iberia, Northwest and Central Europe to the South Urals. Some of the species were first described in Europe; they can be grouped as follows:

A - species with a moderate umbilicus:

P. cyclolobus (Phillips, 1836): with the conch ratios $\mathrm{ww} / \mathrm{dm}=0.30, \mathrm{uw} / \mathrm{dm}=0.30$ at $32 \mathrm{~mm} \mathrm{dm}$ and $\mathrm{a}$ strongly pouched first lateral lobe;

P. molaris Korn, 1988: with the conch ratios ww/ $\mathrm{dm}=0.32, \mathrm{uw} / \mathrm{dm}=0.25$ at $35 \mathrm{~mm} \mathrm{dm}$ and a lanceolate first lateral lobe;

P. meridionalis Korn, 1997: with the conch ratios $\mathrm{ww} / \mathrm{dm}=0.26, \mathrm{uw} / \mathrm{dm}=0.28$ at $40 \mathrm{~mm} \mathrm{dm}$ and $\mathrm{a}$ weakly pouched first lateral lobe.
B - species with a narrow umbilicus:

P. ludfordi Bisat, 1955: with a narrow umbilicus (uw/ $\mathrm{dm}$ appr. 0.20 at $25 \mathrm{~mm} \mathrm{dm}$ ) and a strongly pouched first lateral lobe and pouched and narrow additional lateral lobes;

P. owodenkoi n. sp.: with the conch ratios ww/ $\mathrm{dm}=0.35, \mathrm{uw} / \mathrm{dm}=0.20$ at $30-40 \mathrm{~mm} \mathrm{dm}$ and a weakly pouched first lateral lobe and lanceolate additional lateral lobes.
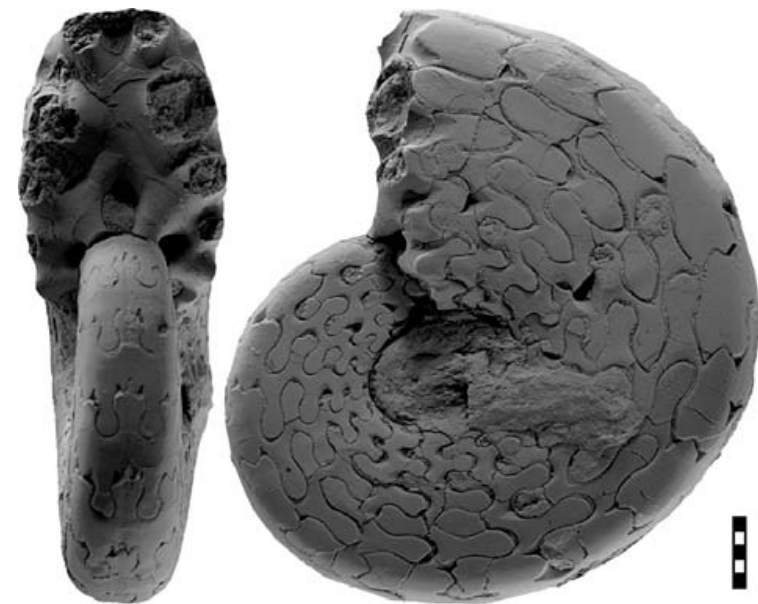

Figure 71. Pronorites owodenkoi n. sp., holotype MB.C.13287.1 from Chebket el Hamra; × 1.5. 


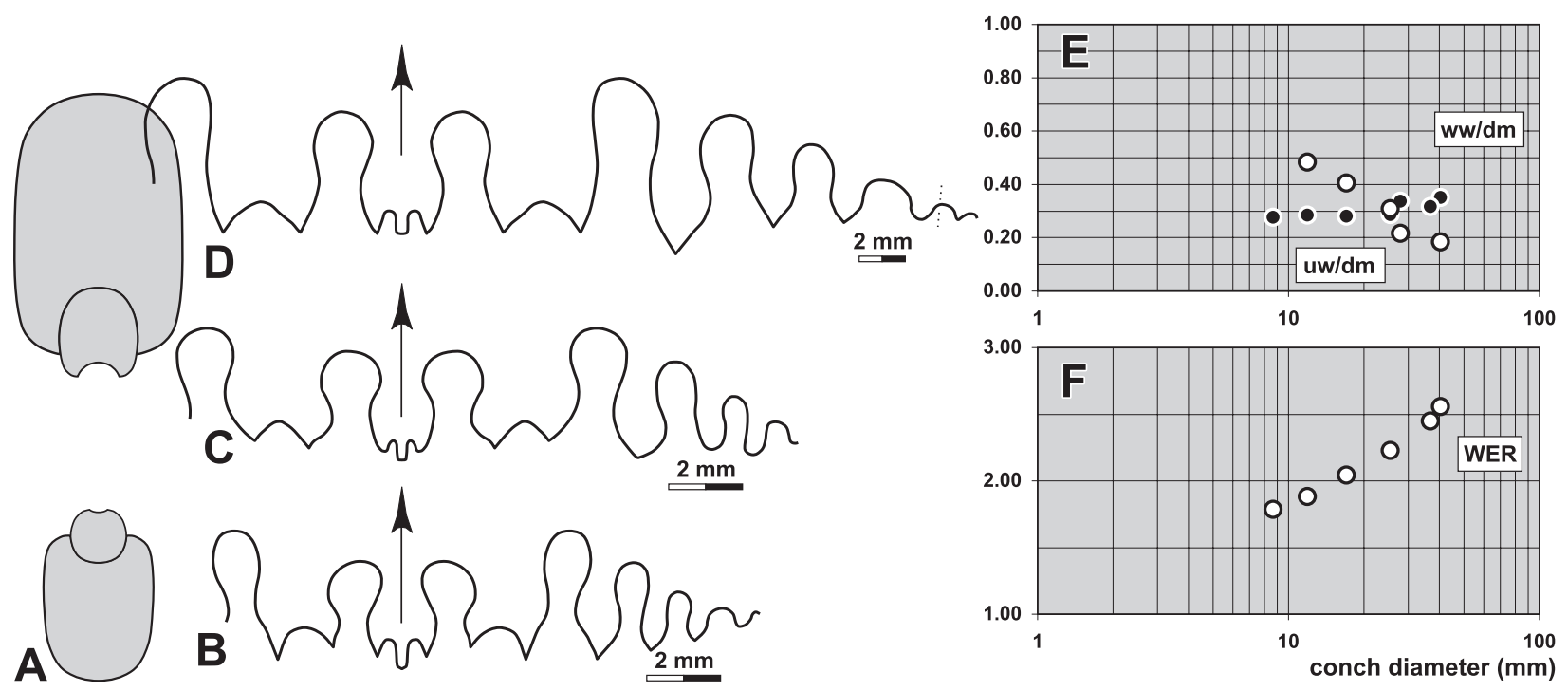

Figure 72. Pronorites owodenkoi n. sp. A. Cross section of paratype MB.C.13244.1 from locality Chebket el Hamra-I; $\times 2.5$. B. Suture line of paratype MB.C.13282.1 from locality Chebket el Hamra-T, at $5.4 \mathrm{~mm}$ ww, $7.7 \mathrm{~mm}$ wh; $\times 4.0$. C. Suture line of holotype MB.C.13287.1 from Chebket el Hamra, at $7.3 \mathrm{~mm} w w, 9.2 \mathrm{~mm}$ wh; $\times 4.0$. D. Suture line of holotype MB.C.13287.1 from Chebket el Hamra, at $40.3 \mathrm{~mm} \mathrm{dm}, 13.1 \mathrm{~mm}$ ww, $20.5 \mathrm{~mm}$ wh; $\times 2.5$. E, F. Ontogenetic development of the conch width index (ww/dm), umbilical width index (uw/dm) and whorl expansion rate (WER) of all available specimens.

\section{Pronorites owodenkoi n. sp.}

Figures $71-72$

Derivation of name. After Boris Owodenko, the pioneer mapping geologist in the Jerada Basin.

Holotype. Specimen MB.C.13287.1 (Korn \& Ebbighausen 2006 Coll.); illustrated in Figure 71.

Type locality and horizon. Chebket el Hamra (Jerada Basin, NE-Morocco); horizon CeH-2, Arnsbergites gracilis Zone or Neoglyphioceras spirale Zone (late Brigantian, Early Carboniferous).

Material. 15 limonitic steinkern specimens of 20 to $41 \mathrm{~mm}$ in conch diameter, from horizon CeH-2 at localities Chebket el Hamra-I, T, and an unspecified locality.

Diagnosis. Pronorites with thinly discoidal conch (ww/dm 0.28-0.35) in all growth stages; umbilicus wide in juveniles $(\mathrm{ww} / \mathrm{dm}=0.48$ at $10 \mathrm{~mm} \mathrm{dm}$ ) and later moderately narrow (uw/dm 0.20 at $30-40 \mathrm{~mm}$ $\mathrm{dm})$. Whorl cross section compressed, flanks flattened and venter rounded. Shell almost smooth with very fine growth lines. Suture line with strongly pouched external lobe, a weakly pouched first lateral lobe and lanceolate additional lateral lobes.

Description. The morphometric data show the ontogenetic changes typical for a Pronorites species (Figs 72E, F). While the whorl width ratio is almost constant at 0.30 between 10 and $40 \mathrm{~mm}$ conch diameter, the umbilical width ratio decreases from 0.50 to 0.20 during this growth interval. At the same time, the apertural height increases rapidly, being visible in the whorl expansion rate of 1.80 at $10 \mathrm{~mm} \mathrm{dm}$ and 2.50 at $40 \mathrm{~mm} \mathrm{dm}$.

Cross section MB.C.13244.1 shows only two preserved whorls but allows insight into the ontogenetic changes between 8 and $25 \mathrm{~mm} \mathrm{dm}$ (Fig. 72A). The whorl cross section is almost circular at $8.6 \mathrm{~mm} \mathrm{dm}$, but half a whorl later, at $11.9 \mathrm{~mm} \mathrm{dm}$, the flanks become somewhat compressed. The last preserved whorl shows flattened parallel flanks and a rounded venter.
Holotype MB.C.13287.1 is the largest individual at a conch diameter of $40 \mathrm{~mm}$ and is fully chambered (Fig. 71). It is somewhat distorted tectonically but otherwise well preserved. The end of the last whorl shows a modification of the arrangement of the flattened parallel flanks, which become subparallel and converging because of a rather rapid widening of the whorl in the umbilical area. The umbilical wall is oblique at this stage.

The suture line of the holotype MB.C.13287.1 shows, at a conch diameter of $40 \mathrm{~mm}$, a strongly pouched external lobe, a weakly pouched adventive lobe and five lateral lobes. The outer three are on the flanks, the fourth on the umbilical margin, and the fifth on the umbilical wall. The first lateral lobe is narrow and pouched, the second and third are lanceolate (Fig. 72D).

Suture lines in smaller stages, such as those on the same specimen at $7.3 \mathrm{~mm}$ ww and paratype MB.C. 13282.1 at $5.4 \mathrm{~mm}$ ww are generally similar but show some variability in the shapes of lobes and saddles (Figs 72B, C).

Discussion. Pronorites owodenkoi differs from the two British species P. cyclolobus and P. ludfordi in having lesser pouched lateral lobes, from the South Portuguese $P$. meridionalis in the narrower umbilicus, and from the Rhenish P. molaris in the stronger pouched first lateral lobe.

\section{Acknowledgements}

We are deeply indebted to Yahia Zirar (Touissit) for his assistance during the collecting of samples from the Chebket el Hamra; Markus Aretz and Hans-Georg Herbig (Köln) for the introduction to the geol- 
ogy of the Jerada Basin, and Dieter Weyer (Berlin) for accompanying $\mathrm{VE}$ on the second field excursion. Permission for the field work was generously given by the local authorities.

We thank Sarah Long (British Museum of Natural History, London) for access to the Carboniferous ammonoid collections during a stay of DK in the course of a SYNTHESYS grant. The German Research Foundation (DFG) supported the field work in North Africa with research grant KO1829-3. Many thanks to Evelin Stenzel and Markus Brinkmann (Berlin) for the mechanical preparation of a number of specimens, and to Wolfgang Gerber (Tübingen) for taking the photographs. Many thanks to Kristin Polizzotto (New York), Markus Aretz (Köln), Christian Klug (Zürich), and John Malinky (San Diego) for the careful review of the manuscript.

\section{References}

Berkhli, M., Paicheler, J.-C. \& Vachard, D. 1993. Données nouvelles sur la stratigraphie des terrains Carbonifères de la Meseta orientale marocaine (boutonnières de Debdou, Mekam et Jerada). Geologische Rundschau 82: 84-100.

Berkhli, M., Vachard, D., Paicheler, J.-C. \& Tahiri, A. 1999a. Séries volcano-sédimentaires du Carbonifère inférieur du Maroc oriental; datation, composition et implication structurale. - Comptes Rendus de l'Académie des Sciences, Série II. Sciences de la Terre et des Planètes 329 (2): 89-94.

Berkhli, M., Vachard, D., Tahiri, A. \& Paicheler, J.-C. 1999b. Stratigraphie séquentielle du Viséen supérieur du bassin de Jerada (Maroc Oriental). - Eclogae geologicae Helveticae 92: 285-294.

Bisat, W. S. 1924. The Carboniferous goniatites of the north of England and their zones. - Proceedings of the Yorkshire Geological Society 20: 40-124.

Bisat, W. S. 1928. The Carboniferous goniatite zones of England and their continental equivalents. - Compte Rendue Congrès International de Stratigraphie et de Géologie du Carbonifère (Heerlen 1927), 117-133.

Bisat, W. S. 1934. The goniatites of the Beyrichoceras Zone in the north of England. - Proceedings of the Yorkshire Geological Society 22: 280-309.

Bisat, W. S. 1950. The junction faunas of the Viséan and Namurian. Transactions of the Leeds Geological Association 6: 10-26.

Bisat, W. S. 1952. The goniatite succession al Cowdale Clough, Barnoldswick, Yorkshire. - Transactions of the Leeds Geologists Association 6 (4): 155-181.

Bisat, W. S. 1955. On Neoglyphioceras spirale (Phill.) and allied species. - Publication de 1'Association pour l'Étude de la Paléontologie de la Stratigraphie Houillères 21 (8): 13-28.

Bisat, W. S. 1957. Upper Viséan goniatites from the Manifold Valley, North Staffordshire. - Palaeontology 1: 16-21.

Bockwinkel, J. \& Ebbighausen, V. 2006. A new ammonoid fauna from the Gattendorfia-Eocanites Genozone of the Anti-Atlas (Early Carboniferous, Morocco). - Fossil Record 9 (1): 87-129.

Bogoslovskaya, M. F. 1966. Rod Goniatites i ego predstavateli na Yuzhnom Urale. - Paleontologicheskiy Zhurnal 1966 (1): 38-46.

Bouckaert, J. \& Owodenko, B. 1965. Namurian Goniatite succession in the Coalfield of Djerada (Eastern Morocco). - Bulletin de la Société belge de Géologie, Paléontologie et Hydrologie 73: 454-463.

Brandon, A. \& Hodson, F. 1984. The stratigraphy and palaeontology of the late Visean and early Namurian rocks of North-east Connaught. - Geological Survey of Ireland, Special Paper 6: 1-54.

Brichant, A. L. 1932. Observations sur les terrains paléozoïques du Maroc oriental. - Compte Rendu de la Société géologique de France 1932 (5): 66-68.

Brichant, A. L. 1935. Contribution a la connaissance de la stratigraphie et de la tectonique des terrains antéhercyniens du Maroc oriental. - Bulletin de la Société géologique de France, 5ème série 5: $541-558$.
Brown, T. 1841. Description of some new species of fossil shells, found chiefly in the Vale of Todmorden, Yorkshire. - Transactions of the Manchester Geological Society 1: 212-229.

Brüning, K. 1923a. Beiträge zur Kenntnis des Rheinisch-westfälischen Unterkarbons, insbesondere der Goniatiten und Korallen in der stratigraphischen Stellung und Gliederung. Marburg: 1-59.

Brüning, K. 1923b. Beiträge zur Kenntnis des rheinisch-westfälischen Unterkarbons. - Geologisches Archiv 1: 263-266.

Clariond, L. 1933. A propos d'un forage exécuté à l'Ouest du Bassin houiller de Djerada (Région d'Oudjda-Maroc Oriental). - Compte Rendu de la Societé géologique de France 1933 (7): 83-84.

Clariond, L. \& Termier, H. 1933. La base du Carbonifère dans le bassin de Djerada (Maroc oriental). - Compte Rendu de la Societé géologique de France 1933 (12): 176-178.

Delépine, G. 1935. Contribution à l'étude de la faune du Dinantien des Pyrénées. Première partie. Goniatites et Crustacés des nodules phosphatés de l'Ariège. - Bulletin de la Société Géologique de France 5 (5): 65-75.

Delépine, G. 1940. Les goniatites du Dinantien de la Belgique. Mémoires du Musée Royal d'Histoire Naturelle de Belgique 91: $1-91$.

Delépine, G. 1941. Les goniatites du Carbonifère du Maroc et des confins Algéro-Marocains du sud (Dinantien-Westphalien). Notes et Mémoires, Service géologique, Protectorat de l'État Français au Maroc 56: 1-111.

Dollé, L. 1912. Le Dinantien supérieur (Viséen) de la vallée de l'Oued-Zousfana. - Annales de la Société Géologique du Nord 41: 240-261.

Ebbighausen, V. \& Bockwinkel, J. 2007. Tournaisian (Early Carboniferous/Mississippian) ammonoids from the Ma'der Basin (Anti-Atlas, Morocco). - Fossil Record 10 (2): 125-163.

Ebbighausen, V., Bockwinkel, J., Korn, D. \& Weyer, D. 2004. Early Tournaisian ammonoids from Timimoun (Gourara, Algeria). Mitteilungen aus dem Museum für Naturkunde Berlin, Geowissenschaftliche Reihe 7: 133-152.

Feio, M. 1946. Note sur un gisement de fossiles viséen dans les environs de Mértola. - Comunicações dos Serviços Geológicos de Portugal 27: 99-117.

Foord, A. H. \& Crick, G. C. 1897. Catalogue of the fossil Cephalopoda in the British Museum (Natural History). Part III. Containing the Bactritidae, and part of the suborder Ammonoidea. London: 303 pp.

Frech, F. 1897-1902. Lethaea geognostica oder Beschreibung und Abbildung der für die Gebirgs-Formationen bezeichnendsten Versteinerungen. I. Theil. Lethaea palaeozoica. 2. Band.

Girty, G. H. 1909. The fauna of the Caney Shale of Oklahoma. Bulletin of the U.S. Geological Survey 377: 1-106.

Gischler, E. \& Korn, D. 1992. Goniatiten des Ober-Viseums aus Decksedimenten des Iberger Riffes, Oberharz. - Neues Jahrbuch für Geologie und Paläontologie, Abhandlungen 185 (3): 271-288.

Gordon, M. 1971. Goniatites americanus n. sp., a late Meramec (Mississippian) index fossil. - U.S. Geological Survey Professional Paper 750-C: C39-C43.

Haan, G. de 1825. Monographia Ammoniteorum et Goniatiteorum. Lugduni Batavorum, Hazenberg: 168 pp.

Hall, J. 1860. Notes and observations upon fossils of the Goniatite Limestone in the Marcellus shale of the Hamilton group, in the eastern and central parts of the State of New York, and those of the Goniatite beds of Rockford, Indiana; with some analagous forms from the Hamilton group proper. - Annual Reports of the Regents of the University of the State New York, on the condition of the State Cabinet of Natural History, and the Historical and Antiquarian Collection annexed thereto 13: 59-112, 125.

Harroy, J. \& Brichant, A. 1928. Note préliminaire sur la découverte d'un basin houiller au Maroc oriental. - Annales de la Société géologique de Belgique 52: 53-54. 
Haubold, W. 1933. Über das Unterkarbon auf Blatt Goddelsheim am Ostrande des Rheinischen Schiefergebirges. - Jahrbuch der PreuBischen Geologischen Landesanstalt 53 (for 1932): 208-246.

Hind, W. 1918. On the distribution of the British Carboniferous Goniatites, with a description of one new genus and some new species. - Geological Magazine 5 (10): 434-450.

Hodson, F. 1954. A new species of Dimorphoceras from the Homoceras Zone of the Irish Millstone Grit. - Annual Magazine of natural History, Zoology, Botany, Geology, new series 12 (7), N77: 362-366.

Hodson, F. \& Moore, E. W. J. 1959. Goniatites striatus and related forms from the Viséan of Ireland. - Palaeontology 1 (4): 384-396.

Hoeck, H. 1929. Ueber den Culm an der Edertalsperre. Ein Beitrag zur Kenntnis des Culms am Ostrande der Rheinischen Masse. Neues Jahrbuch für Mineralogie, Geologie und Paläontologie, Beilage-Band B61: 1-40.

Horon, O. 1952. Contribution a l'étude du bassin houiller de Djerada (Maroc oriental) (Résultats des recherches exécutées par le bureau recherches et de participations minières dès 1946 à 1951). Notes et Mémoires, protectorat de la république française au Maroc. Direction de la production industrielle et des mines. Division des mines et de la géologie. Service géologique 83: 1-180.

Hyatt, A. 1883-1884. Genera of fossil cephalopods. - Proceedings of the Boston Society of Natural History 22: 253-338 (253-272 publ. 1883, 273-338 publ. 1884).

Karpinsky, A. P. 1889. Über die Ammoneen der Artinsk-Stufe und einige mit denselben verwandte carbonische Formen. - Mémoires de l'Académie Impériale des Sciences de St. Pétersbourg, VIIe Série 37 (2): 1-104,

Klug, C., Döring, S., Korn, D. \& Ebbighausen, E. 2006. The Viséan sedimentary succession at the Gara el Itima (Anti-Atlas, Morocco) and its ammonoid faunas. - Fossil Record 9 (1): 3-60.

Knopp, L. 1931. Ueber die unterkarbonischen Goniatiten der Ostsudeten. - Lotos 79 (1): 8-33.

Kobold, A. 1933. Die Gliederung des Oberharzer Kulms nach Goniatiten. Stratigraphische Beobachtungen im Kulm des nordwestlichen Oberharzes unter besonderer Berücksichtigung der Grauwacken. Jahrbuch der Preußischen Geologischen Landesanstalt 53 (for 1932): 450-515.

Koninck, L.-G. de 1844. Description des animaux fossiles qui se trouvent dans le terrain Carbonifère de la Belgique. Liège: I-IV, 1716.

Koninck, L.-G. de 1880. Faune du Calcaire Carbonifère de la Belgique. Deuxième partie. Genres: Gyroceras, Cyrtoceras, Gomphoceras, Orthoceras, Subclymenia et Goniatites. - Annales du Musée Royal d'Histoire Naturelle de Belgique, Série Paléontologique 5: $1-133$.

Korn, D. 1988. Die Goniatiten des Kulmplattenkalkes (Cephalopoda, Ammonoidea; Unterkarbon; Rheinisches Schiefergebirge). - Geologie und Paläontologie in Westfalen 11: 1-293.

Korn, D. 1990a. Weitere Goniatiten aus dem Ober-Visé des Rheinischen Schiefergebirges. - Geologie und Paläontologie in Westfalen 15: 11-69.

Korn, D. 1990b. The goniatite succession in the Lower Carboniferous P1b Zone in North Leitrim. - Irish Journal of Earth Sciences 10 (1990): 109-114.

Korn, D. 1996. Revision of the Late Viséan goniatite stratigraphy. Annales de la Société géologique de Belgique 117 (1): 205-212.

Korn, D. 1997. The Palaeozoic ammonoids of the South Portuguese Zone. - Memórias do Instituto Geológico e Mineiro de Portugal 33: 1-132.

Korn, D. 2000. Morphospace occupation of ammonoids over the Devonian-Carboniferous boundary. - Paläontologische Zeitschrift 74 (3): $247-257$.

Korn, D., Bockwinkel, J. \& Ebbighausen, V. 2007. The Tournaisian and Viséan ammonoid stratigraphy in North Africa. - Neues Jahrbuch für Geologie und Paläontologie 243 (2): 127-148.
Korn, D., Bockwinkel, J., Ebbighausen, V. \& Klug, C. 2003. Palaeobiogeographic and evolutionary meaning of an early Late Tournaisian ammonoid fauna from the Tafilalt of Morocco. - Acta Palaeontologica Polonica 48 (1): 71-92.

Korn, D., Ebbighausen, V., Bockwinkel, J. \& Klug, C. 2003. The Amode sutural ontogeny in prolecanitid ammonoids. - Palaeontology 46 (6): 1123-1132.

Korn, D. \& Feist, R. 2007. Early Carboniferous ammonoid faunas and stratigraphy of the Montagne Noire (France). - Fossil Record 10 (2): 99-124.

Korn, D. \& Ilg, A. 2007. AMMON, www.wahre-staerke.com/ammon/

Korn, D., Klug, C. \& Mapes, R. 2004. Cuboid Carboniferous ammonoids. - Mitteilungen aus dem Geologisch-Paläontologischen Institut der Universität Hamburg 88: 79-97.

Korn, D., Klug, C. \& Mapes, R. 2005. The Lazarus ammonoid genus Goniatites, the tetrangularly coiled Entogonites, and Early Carboniferous biogeography. - Journal of Paleontology 79 (2): 149158.

Korn, D. \& Tilsley, J. 2006. Ammonoid assemblages from the Asbian $\mathrm{B}_{2 \mathrm{~b}}$ (Early Carboniferous: Mississippian) buildups of the Peak District, England. - Proceedings of the Yorkshire Geological Society 56 (2): 101-150.

Kumpera, O. 1971. Faunistické lokality a prehled fauny Moravického souvrství (Svrchní Visé). - Sborník vedeckých prací Vysoké Skoly Bánské v Ostrave 17 (1): 107-124.

Liang Xi-luo \& Wang Mingqian 1991. Carboniferous cephalopods of Xinjiang. - Paleontologica Sinica, new series B 180: 1-171.

Librovitch, L. S. 1957. O nekotorykh novykh gruppakh goniatitov iz kamennougol'nykh otlozheniy SSSR. - Ezhegodnik Vsesoyuznogo Paleontologicheskogo Obshchestva 16: 246-272.

Malinky, J. M. \& Mapes, R. H. 1982. A new ferganoceratin ammonoid from the Mississippian (Lower Chesterian) of Arkansas. Journal of Paleontology 56 (2): 308-314.

Manger, W. L. 1988. Phylogeny of the Carboniferous Ammonoid Family Dimorphoceratidae. In Wiedmann, J. \& Kullmann, J. (eds). Cephalopods - Present and Past. Schweizerbart, Stuttgart: pp. 29-42.

Martin, W. 1809. Petrificata Derbiensia; or, Figures and Descriptions of Petrifactions collected in Derbyshire. Wigan: $28 \mathrm{pp}$.

Menchikoff, N. 1930. Recherches géologiques et morphologiques dans le nord du Sahara occidental. - Revue de Géographie physique et de Géologie dynamique 3 (2): 103-247.

Mestermann, B. 1998. Mikrofazies, Paläogeographie und Eventgenese des crenistria-Horizontes (Obervisé, Rhenohercynicum). - Kölner Forum für Geologie und Paläontologie 2: 1-77.

Miller, S. A. 1889. North American geology and palaeontology. Cincinatti, Ohio: pp. 1-793.

Mojsisovics, E. von Mojsvar 1882. Die Cephalopoden der mediterranen Triasprovinz. - Abhandlungen der kaiserlichen und königlichen geologischen Reichsanstalt 10: 1-322.

Moore, E. W. J. 1936. The Bowland Shales from Pendle to Dinckley. - Journal of the Manchester Geological Association 1: 167-192.

Moore, E. W. J. 1939. The goniatite genus Dimorphoceras and its development in the British Carboniferous. - Proceedings of the Yorkshire Geological Society 24 (2): 103-128.

Moore, E. W. J. 1946. The Carboniferous Goniatite Genera Girtyoceras and Eumorphoceras. - Proceedings of the Yorkshire Geological Society 25: 387-445.

Moore, E. W. J. 1950. The Genus Sudeticeras and its Distribution in Lancashire and Yorkshire. - Journal of the Manchester Geological Association 1950 (2): 31-50.

Moore, E. W. J. 1952. Notes on the genera Prolecanites and Epicanites with description of two new species. - Liverpool and Manchester Geological Journal 1 (1): 71-76.

Moore, E. W. J. 1958. Dimorphoceratidae from the Upper Visean shales of County Leitrim, Eire. - Proceedings of the Yorkshire Geological Society 31 (3): 219-226. 
Moore, E. W. J. \& Hodson, F. 1958. Goniatites from the Upper Viséan shales of County Leitrim, Eire. - Liverpool and Manchester geological Journal 2 (1): 86-105.

Nicolaus, H.-J. 1963. Zur Stratigraphie und Fauna der crenistria-Zone im Kulm des Rheinischen Schiefergebirges. - Beihefte zum Geologischen Jahrbuch 53: 1-246.

Owodenko, B. 1946. Mémoire explicatif de la carte géologique du bassin houiller de Djerada et la région au sud d'Oujda (Maroc oriental français). - Mémoires du Société Géologique de Belgique 70: 3-163.

Owodenko, B. 1976. Le bassin houiller de Jerada (Maroc oriental). Essai de synthèse et de paléogéographique. - Notes et Mémoires du Service géologique du Maroc 285: 1-148.

Owodenko, B. \& Horon, O. 1952. Échelle stratigraphique du basin houiller de Djérada (Maroc Oriental). - Compte Rendue Troisième Congrès pour l'avancementdes études de stratigraphie et de géologie du Carbonifère 1: 487-492.

Pareyn, C. 1961. Les Massifs Carbonifères du Sahara Sud-Oranais. Tome II. Paléontologie stratigraphique. - Publications du Centre de Recherches Sahariennes, Série Géologie 1: 1-244.

Patteisky, K. 1930. Die Geologie und Fossilführung der mährischschlesischen Dachschiefer und Grauwackenformationen. Naturwissenschaftlicher Verein Troppau: I-XI, pp. 1-354.

Pereira de Sousa, F. L. 1923. Sur un nouveau genre de Goniatite: Lusitanoceras. - Compte Rendu Sommaire et Bulletin de la Société Géologique de France, ser. 4 23: 304.

Phillips, J. 1836. Illustrations of the geology of Yorkshire; or a description of the strata and organic remains; accompanied by a geological map, sections, and diagrams, and figures of the fossils. Part II. The Mountain Limestone District. London: I-XX, pp. 1-259.

Phillips, J. 1841. Figures and descriptions of the Palaeozoic fossils of Cornwall, Devon, and West Somerset. London: I-XII, pp. 1-231.

Plummer, F. B. \& Scott, G. 1937. Upper Paleozoic Ammonites in Texas. In The Geology of Texas, Vol. III, Pt. 1, University of Texas Bulletin 3701: 1-516.

Portlock, J. E. 1843. Report on the geology of the county of Londonderry, and parts of Tyrone and Fermanagh. Dublin: I-XXXI, pp. 1-784.

Riley, N. J. 1996. Mid-Dinantian ammonoids from the Craven Basin, northwest England. - Special papers in Palaeontology 53: 1-87.

Roemer, F. A. 1850. Beiträge zur geologischen Kenntnis des nordwestlichen Harzgebirges. - Palaeontographica 3: 1-69.

Ruprecht, L. 1937. Die Biostratigraphie des obersten Kulm im Sauerlande. - Jahrbuch der Preußischen Geologischen Landesanstalt 57 (for 1936): 238-283.

Ruzhencev, V. E. 1960. Printsipy sistematiki, sistema i filogeniya paleozoyskikh ammonoidey. - Trudy Paleontologicheskogo Instituta Akademiya Nauk SSSR 133: 1-331.

Ruzhencev, V. E. \& Bogoslovskaya, M. F. 1970. Reviziya nadsemeystva Goniatitaceae. - Paleontologicheskiy Zhurnal 1970 (4): 52-65.
Ruzhencev, V. E. \& Bogoslovskaya, M. F. 1971. Namyurskiy etap v evolyutsii ammonoidey. Rannenamyurskie ammonoidei. - Trudy Paleontologicheskogo Instituta Akademiya Nauk SSSR 133: 1382

Sandberger, G. \& Sandberger, F. 1850-1856. Die Versteinerungen des rheinischen Schichtensystems in Nassau. Mit einer kurzgefassten Geognosie dieses Gebietes und mit steter Berücksichtigung analoger Schichten anderer Länder. Wiesbaden: XIV + $564 \mathrm{pp}$.

Schindewolf, O. H. 1934. Über zwei jungpaläozoische Cephalopodenfaunen von Menorca. - Abhandlungen der Gesellschaft der Wissenschaften in Göttingen, Mathematisch-Physikalische Klasse III (10): 159-191.

Schindewolf, O. H. 1951. Über ein neues Vorkommen unterkarbonischer Pericyclus-Schichten im Oberharz. - Neues Jahrbuch für Geologie und Paläontologie, Abhandlungen 93 (1): 23-116.

Schmidt, H. 1925. Die carbonischen Goniatiten Deutschlands. - Jahrbuch der Preußischen Geologischen Landesanstalt 45 (for 1924): 489-609.

Sheng Huaibin 1983. The ammonoids of late Lower Carboniferous from Yongzhu village, Xainza district in North Xizang. In The Geology of the Qinghai-Xizang (Tibet) Plateau: pp. 41-68.

Sowerby, J. 1812-1814. The mineral conchology of Great Britain; or coloured figures and descriptions of those remains of testaceous animals or shells, which have been preserved at various times and depths in the earth. Vol. I. London: 234 pp.

Tchernow, A. A. 1907. Artinskiy yarus. I. ammonei basseynov Yayvy, Kos'vy i Chusovoy. Vypusk' I. Vvedenie. Obzor izsledovanoy mestnosti. Prolecanitidae. - Byulleten' Moskovskaya obshchestva ispytatelei prirody $20(3,4)$ : 270-401.

Termier, H. 1936a. Études géologiques sur le Maroc Central et le Moyen Atlas Septentrional. Tome I. Les Terrains Primaires et le Permo-Trias. - Protectorat de la République Française au Maroc, Direction Générale des Travaux Publics, Service des Mines et de la Carte Géologique, Notes et Mémoires 33: 1-743.

Termier, H. 1936b. Études géologiques sur le Maroc Central et le Moyen Atlas Septentrional. Tome III. Paléontologie, Pétrographie. - Protectorat de la République Française au Maroc, Direction Générale des Travaux Publics, Service des Mines et de la Carte Géologique, Notes et Mémoires 33: 1087-1421.

Vachard, D. \& Berkhli, M. 1992. Importance des coupes du Bassin de Jerada (Maroc) pour la connaissance du Viséen terminal. - Revue de Micropaléontologie 35 (4): 307-332.

Wedekind, R. 1918. Die Genera der Palaeoammonoidea Goniatiten). Mit Ausschluß der Mimoceratidae, Glyphioceratidae und Prolecanitidae. - Paläontographica 62: 85-184.

Weyer, D. 1972. Trilobiten und Ammonoideen aus der Entogonites nasutus-Zone (Unterkarbon) des Büchenberg-Sattels (Elbingeröder Komplex, Harz). Teil I. - Geologie 21 (2): 166-184. 


\section{Appendix}

A. List of sampled localities at the Chebket el Hamra with their ammonoid material.

Locality CeH-A (Korn \& Ebbighausen 2006 coll.), limonitic material (horizon CeH-3): Metadimorphoceras hodsoni Moore, 1958

Sudeticeras murracaoense Korn, 1997

3 specimens (MB.C.13201.1-3)

Locality CeH-B (Korn \& Ebbighausen 2006 coll.), limonitic material (horizon $\mathrm{CeH}-3$ ): Sudeticeras murracaoense Korn, 1997

60 specimens (MB.C.13202.1-60)

Locality CeH-C (Korn \& Ebbighausen 2006 coll.), limonitic material (horizon $\mathrm{CeH}-3$ ): Metadimorphoceras hodsoni Moore, 1958

Sudeticeras murracaoense Korn, 1997

Locality CeH-D (Korn \& Ebbighausen 2006 coll.), limonitic material and phosphatic nodules (horizon $\mathrm{CeH}-5$ ):

1 specimen (MB.C.13204)

30 specimens (MB.C.13205.1-30)

Lusitanoceras zirari $\mathrm{n}$. sp.

Sudeticeras splendens (Bisat, 1928)

Lusitanites circularis Korn, 1988

Locality CeH-E (Korn \& Ebbighausen 2006 coll.), limonitic material (horizon CeH-2): Hibernicoceras carraunense Moore \& Hodson, 1958

Neoglyphioceras spirale (Phillips, 1841)

Praedaraelites culmiensis (Kobold, 1933)

Same locality, drifted sideritic nodules (horizon $\mathrm{CeH}-4$ ):

Sudeticeras horoni $\mathrm{n}$. sp.

Locality CeH-F (Korn \& Ebbighausen 2006 coll.), limonitic material (horizon CeH-2):

Girtyoceras luscinia Korn, 1988

Girtyoceras ibnkhaldouni n. sp.

Sulcogirtyoceras sp.

Metadimorphoceras anguinosum $\mathrm{n}$. $\mathrm{sp}$.

Arnsbergites sphaericostriatus (Bisat, 1924)

Arnsbergites ferrus n. sp.

Arnsbergites proiecturus n. sp.

Hibernicoceras carraunense Moore \& Hodson, 1958

Hibernicoceras touissitense $\mathrm{n}$. $\mathrm{sp}$.

Hibernicoceras artilobatum $\mathrm{n}$. sp.

Paraglyphioceras rudis (Moore \& Hodson, 1958)

Paraglyphioceras celeris n. $\mathrm{sp}$.

Sudeticeras ibnbajjahi n. sp.

Neoglyphioceras spirale (Phillips, 1841)

Praedaraelites culmiensis (Kobold, 1933)

Locality CeH-G (Korn \& Ebbighausen 2006 coll.), limonitic material (horizon CeH-2):

Girtyoceras luscinia Korn, 1988

Girtyoceras ibnkhaldouni n. sp.

Girtyoceras sp.

Praedaraelites culmiensis (Kobold, 1933)

Locality CeH-H (Korn \& Ebbighausen 2006 coll.), from sideritic nodules (horizon CeH-1): Goniatites crenistria Phillips, 1836

Locality CeH-I (Korn \& Ebbighausen 2006 coll.), limonitic material (horizon CeH-2):

Metadimorphoceras anguinosum $\mathrm{n}$. sp.

Arnsbergites sphaericostriatus (Bisat, 1924)

Arnsbergites ferrus n. sp.

Hibernicoceras carraunense Moore \& Hodson, 1958

Hibernicoceras touissitense $\mathrm{n}$. sp.

Hibernicoceras artilobatum $\mathrm{n} . \mathrm{sp}$.

Paraglyphioceras rudis (Moore \& Hodson, 1958)

Paraglyphioceras celeris $\mathrm{n}$. $\mathrm{sp}$.

Sudeticeras ibnbajjahi n. sp.

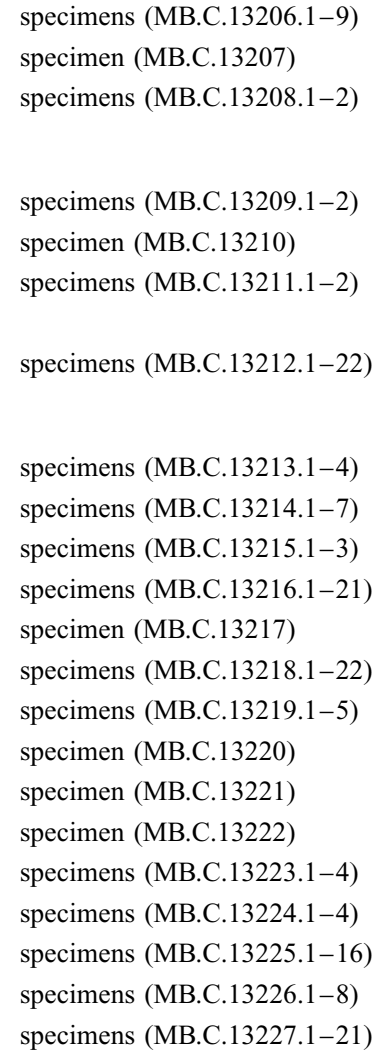

specimens (MB.C.13232.1-3)

specimens (MB.C.13233.1-2)

specimen (MB.C.13234)

specimens (MB.C.13235.1-6)

specimens (MB.C.13236.1-12)

specimens (MB.C.13237.1-39)

specimens (MB.C.13238.1-3)

specimens (MB.C.13239.1-13)

specimens (MB.C.13240.1-4)

specimens (MB.C.13241.1-4) 
Neoglyphioceras spirale (Phillips, 1841)

Praedaraelites culmiensis (Kobold, 1933)

Pronorites owodenkoi n. sp.

Locality CeH-J (Korn \& Ebbighausen 2006 coll.), exposed in small gully (Liassic):

Dactylioceras sp.

Same locality, drifted sideritic nodules (horizon $\mathrm{CeH}-4$ ):

Sudeticeras horoni $\mathrm{n}$. sp. specimens (MB.C.13242.1-6)

specimens (MB.C.13243.1-5)

5 specimens (MB.C.13244.1-5)

2 specimens (MB.C.13245.1-2)

1 specimen (MB.C.13246)

Locality CeH-K (Korn \& Ebbighausen 2006 coll.), limonitic material and phosphatic nodules (horizon CeH-5):

Lusitanoceras zirari $\mathrm{n}$. sp.

Sudeticeras splendens (Bisat, 1928)

Lusitanites circularis Korn, 1988 specimens (MB.C.13247.1-16)

specimens (MB.C.13248.1-2) specimens (MB.C.13249.1-2)

Locality CeH-L (Korn \& Ebbighausen 2006 coll.), limonitic material and phosphatic nodules (horizon CeH-5):

Lusitanoceras zirari $\mathrm{n}$. sp.

Same locality (horizon CeH-6)

Sudeticeras splendens (Bisat, 1928)

Locality CeH-M (Korn \& Ebbighausen 2006 coll.), limonitic material and phosphatic nodules (horizon $\mathrm{CeH}-6)$ :

Sudeticeras splendens (Bisat, 1928)

Sudeticeras sp.

Locality CeH-N (Korn \& Ebbighausen 2006 coll.), from sideritic nodules (horizon CeH-1):

Goniatites crenistria Phillips, 1836

Goniatites globostriatus (Schmidt, 1925)

Same locality (Ebbighausen \& Weyer 2007 coll.)

Goniatites crenistria Phillips, 1836
3 specimens (MB.C.13250.1-3)

4 specimens (MB.C.13251.1-4)

specimens (MB.C.13252.1-3)

specimen (MB.C.13253)

specimens (MB.C.13254.1-30)

specimens (MB.C.13255.1-3)

specimens (MB.C.13256.1-43)

Locality CeH-O (Ebbighausen \& Weyer 2007 coll.), limonitic material and phosphatic nodules (horizon CeH-5):

Lusitanoceras zirari $\mathrm{n}$. sp.

Same locality, sideritic nodules (horizon $\mathrm{CeH}-6)$

Sudeticeras splendens (Bisat, 1928)

Sudeticeras sp.

Same locality, drifted sideritic nodules (horizon $\mathrm{CeH}-4$ )

Sudeticeras horoni $\mathrm{n}$. sp.

Locality CeH-P (Ebbighausen \& Weyer 2007 coll.), limonitic material and phosphatic nodules (horizon CeH-5)

Lusitanoceras zirari $\mathrm{n}$. sp.

Lusitanites circularis Korn, 1988

Ferganoceras sp.

Same locality, sideritic nodules (horizon $\mathrm{CeH}-6$ )

Sudeticeras splendens (Bisat, 1928)

Same locality, drifted sideritic nodules (horizon $\mathrm{CeH}-4$ )

Sudeticeras horoni $\mathrm{n}$. sp.

Locality CeH-Q (Ebbighausen \& Weyer 2007 coll.), sideritic nodules (horizon CeH-4):

Sudeticeras horoni $\mathrm{n}$. sp.

6 specimens (MB.C.13257.1-6)

4 specimens (MB.C.13258.1-4)

3 specimens (MB.C.13259.1-3)

99 specimens (MB.C.13260.1-99)

Locality CeH-R (Ebbighausen \& Weyer 2007 coll.), drifted sideritic nodules (horizon CeH-4):

Sudeticeras horoni $\mathrm{n}$. sp.

21 specimens (MB.C.13261.1-21)

3 specimens (MB.C.13262.1-3)

1 specimen (MB.C.13263)

31

specimens (MB.C.13264.1-31)

8

specimens (MB.C.13265.1-8)

22

specimens (MB.C.13266.1-22)

5

specimens (MB.C.13267.1-5)

Same locality (horizon CeH-6)

Sudeticeras splendens (Bisat, 1928)

1 specimen (MB.C.13268)

Locality CeH-S (Ebbighausen \& Weyer 2007 coll.), limonitic material (horizon CeH-3):

Eoglyphioceras minutum n. sp.

Metadimorphoceras hodsoni Moore, 1958

Sudeticeras murracaoense Korn, 1997

specimens (MB.C.13269.1-3)

specimens (MB.C.13270.1-11)

specimens (MB.C.13271.1-255)

Locality CeH-T (Ebbighausen \& Weyer 2007 coll.), limonitic material (horizon CeH-2):

Metadimorphoceras anguinosum n. sp.

Arnsbergites sphaericostriatus (Bisat, 1924)

Arnsbergites ferrus n. sp.

Hibernicoceras carraunense Moore \& Hodson, 1958 specimens (MB.C.13272.1-3)

specimens (MB.C.13273.1-16)

specimens (MB.C.13274.1-6)

specimens (MB.C.13275.1-23) 


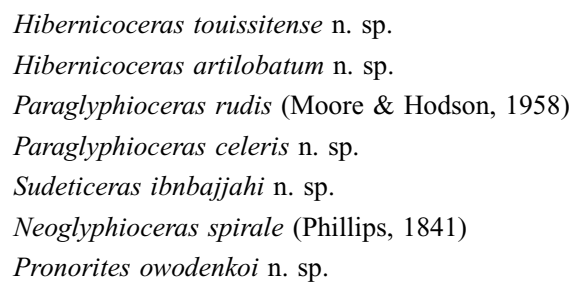

24 specimens (MB.C.13276.1-24)

7 specimens (MB.C.13277.1-7)

81 specimens (MB.C.13278.1-81)

10 specimens (MB.C.13279.1-10)

15 specimens (MB.C.13280.1-15)

1 specimen (MB.C.13281)

8 specimens (MB.C.13282.1-8)

Locality not specified (Korn \& Ebbighausen 2006 purchased), limonitic material and sideritic nodules (horizon CeH-2):

Arnsbergites sphaericostriatus (Bisat, 1924)

Arnsbergites ferrus n. sp.

Arnsbergites rufus n. sp.

Hibernicoceras artilobatum n. sp.

Pronorites owodenkoi n. sp.

Same locality (horizon $\mathrm{CeH}-5$ )

Lusitanoceras zirari $\mathrm{n}$. sp.

Same locality (horizon $\mathrm{CeH}-4$ )

Sudeticeras horoni $\mathrm{n}$. sp.

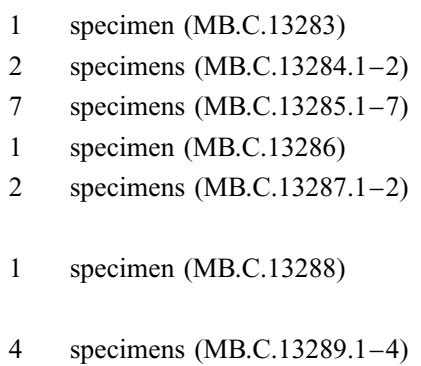

4 specimens (MB.C.13289.1-4)

Locality not specified (Ebbighausen \& Weyer 2007 purchased), limonitic material and sideritic nodules (horizon CeH-2):

Arnsbergites sphaericostriatus (Bisat, 1924)

Arnsbergites ferrus n. sp.

Hibernicoceras touissitense $\mathrm{n}$. $\mathrm{sp}$.

Hibernicoceras artilobatum $\mathrm{n} . \mathrm{sp}$.

Paraglyphioceras rudis (Moore \& Hodson, 1958)

Praedaraelites culmiensis (Kobold, 1933)

Same locality (horizon $\mathrm{CeH}-5$ )

Lusitanoceras zirari $\mathrm{n}$. sp. specimens (MB.C.13290.1-3)
specimens (MB.C.13291.1-2)
specimens (MB.C.13292.1-3)
specimen (MB.C.13293)
specimens (MB.C.13294.1-4)
specimen (MB.C.13295)
specimen (MB.C.13296)

B. Conch dimensions and ratios of ammonoids from the Chebket el Hamra.

\begin{tabular}{|c|c|c|c|c|c|c|c|c|c|c|}
\hline & $\mathrm{dm}$ & ww & wh & uw & ah & ww/dm & ww/wh & $\mathrm{uw} / \mathrm{dm}$ & WER & IZW \\
\hline \multicolumn{11}{|c|}{ Eoglyphioceras minutum n. sp. } \\
\hline MB.C.13269.1 & 11.90 & 7.30 & 6.10 & 1.00 & 3.60 & 0.62 & 1.20 & 0.08 & 2.04 & 0.42 \\
\hline MB.C.13269.3 & 8.60 & 5.40 & 4.40 & 0.80 & 2.30 & 0.63 & 1.24 & 0.10 & 1.88 & 0.50 \\
\hline \multirow[t]{10}{*}{ MB.C.13269.2 } & 10.63 & 6.63 & 5.70 & 0.97 & 2.86 & 0.62 & 1.16 & 0.09 & 1.87 & 0.50 \\
\hline & 7.76 & 5.26 & 3.96 & 0.99 & 1.98 & 0.68 & 1.33 & 0.13 & 1.80 & 0.50 \\
\hline & 5.78 & 4.28 & 2.82 & 1.01 & 1.42 & 0.74 & 1.52 & 0.17 & 1.75 & 0.50 \\
\hline & 4.37 & 3.51 & 1.96 & 0.98 & 1.00 & 0.80 & 1.80 & 0.22 & 1.68 & 0.49 \\
\hline & 3.37 & 2.75 & 1.43 & 0.89 & 0.77 & 0.82 & 1.93 & 0.26 & 1.68 & 0.46 \\
\hline & 2.60 & 2.08 & 1.05 & 0.77 & 0.57 & 0.80 & 1.98 & 0.29 & 1.65 & 0.45 \\
\hline & 2.03 & 1.60 & 0.78 & 0.62 & 0.45 & 0.79 & 2.05 & 0.31 & 1.65 & 0.42 \\
\hline & 1.58 & 1.26 & 0.62 & 0.45 & 0.37 & 0.80 & 2.01 & 0.29 & 1.72 & 0.40 \\
\hline & 1.20 & 1.01 & 0.50 & 0.30 & 0.29 & 0.84 & 2.04 & 0.25 & 1.75 & 0.41 \\
\hline & 0.91 & 0.95 & 0.41 & 0.09 & 0.27 & 1.04 & 2.31 & 0.09 & 2.01 & 0.35 \\
\hline \multicolumn{11}{|c|}{ Girtyoceras Iuscinia Korn, 1988} \\
\hline MB.C.13213.1 & 20.30 & 7.20 & 10.50 & 3.20 & - & 0.35 & 0.68 & 0.16 & - & - \\
\hline MB.C.13228 & 18.80 & 6.90 & 9.00 & 3.90 & 5.20 & 0.37 & 0.76 & 0.21 & 1.93 & 0.42 \\
\hline MB.C.13213.2 & 15.50 & 6.60 & 7.30 & 3.20 & 4.30 & 0.43 & 0.91 & 0.21 & 1.91 & 0.41 \\
\hline MB.C.13213.3 & 8.70 & 4.80 & 3.60 & 2.70 & 2.00 & 0.56 & 1.34 & 0.31 & 1.70 & 0.44 \\
\hline \multirow[t]{8}{*}{ MB.C.13213.4 } & 13.50 & 6.00 & 6.01 & 3.22 & 3.46 & 0.44 & 1.00 & 0.24 & 1.81 & 0.42 \\
\hline & 10.04 & 5.25 & 4.27 & 2.85 & 2.44 & 0.52 & 1.23 & 0.28 & 1.74 & 0.43 \\
\hline & 7.60 & 4.63 & 2.92 & 2.41 & 1.61 & 0.61 & 1.59 & 0.32 & 1.61 & 0.45 \\
\hline & 5.99 & 3.83 & 2.27 & 1.99 & 1.24 & 0.64 & 1.69 & 0.33 & 1.59 & 0.45 \\
\hline & 4.75 & 3.20 & 1.74 & 1.66 & 0.96 & 0.67 & 1.84 & 0.35 & 1.57 & 0.45 \\
\hline & 3.79 & 2.54 & 1.35 & 1.42 & 0.81 & 0.67 & 1.88 & 0.37 & 1.62 & 0.40 \\
\hline & 2.98 & 1.97 & 1.02 & 1.18 & 0.64 & 0.66 & 1.94 & 0.40 & 1.62 & 0.37 \\
\hline & 2.34 & 1.58 & 0.78 & 0.96 & 0.50 & 0.68 & 2.03 & 0.41 & 1.62 & 0.36 \\
\hline
\end{tabular}


B. (continued)

\begin{tabular}{rcccccccccc}
\hline $\mathrm{dm}$ & ww & wh & uw & ah & ww/dm & ww/wh & uw/dm & WER & IZW \\
\hline 1.84 & 1.31 & 0.60 & 0.75 & 0.39 & 0.71 & 2.17 & 0.41 & 1.60 & 0.36 \\
1.46 & 0.98 & 0.49 & 0.57 & 0.32 & 0.67 & 2.00 & 0.39 & 1.64 & 0.35 \\
1.14 & 0.80 & 0.40 & 0.40 & 0.27 & 0.71 & 2.02 & 0.35 & 1.70 & 0.34 \\
0.87 & 0.68 & 0.34 & 0.21 & 0.24 & 0.79 & 2.01 & 0.24 & 1.89 & 0.30
\end{tabular}

Girtyoceras ibnkhaldouni n. sp.

\begin{tabular}{ccccccccccc} 
MB.C.13214.1 & 14.80 & 6.60 & 8.00 & 2.30 & - & 0.45 & 0.83 & 0.15 & - & - \\
\hline MB.C.13214.5 & 11.70 & 5.80 & 5.90 & 2.30 & 3.60 & 0.49 & 0.98 & 0.20 & 2.06 & 0.40 \\
MB.C.13229.1 & 11.40 & 5.50 & 5.60 & 2.20 & 3.60 & 0.48 & 0.99 & 0.19 & 2.15 & 0.35 \\
MB.C.13214.3 & 17.63 & 7.39 & 9.47 & 2.36 & 6.03 & 0.42 & 0.78 & 0.13 & 2.31 & 0.36 \\
& 11.60 & 5.98 & 5.80 & 2.32 & 3.49 & 0.52 & 1.03 & 0.20 & 2.05 & 0.40 \\
& 8.11 & 4.82 & 3.48 & 2.32 & 2.04 & 0.59 & 1.38 & 0.29 & 1.79 & 0.41 \\
MB.C.13214.4 & 11.13 & 5.28 & 5.31 & 2.42 & 3.35 & 0.47 & 0.99 & 0.22 & 2.05 & 0.37 \\
& 7.78 & 4.35 & 3.40 & 2.18 & 2.09 & 0.56 & 1.28 & 0.28 & 1.87 & 0.39 \\
& 5.69 & 3.61 & 2.20 & 1.98 & 1.30 & 0.63 & 1.64 & 0.35 & 1.68 & 0.41 \\
& 4.39 & 2.91 & 1.51 & 1.71 & 0.96 & 0.66 & 1.92 & 0.39 & 1.64 & 0.37 \\
& 3.43 & 2.33 & 1.16 & 1.43 & 0.75 & 0.68 & 2.00 & 0.42 & 1.63 & 0.36 \\
& 2.69 & 1.76 & 0.84 & 1.19 & 0.56 & 0.65 & 2.09 & 0.44 & 1.60 & 0.33 \\
& 2.12 & 1.38 & 0.65 & 0.97 & 0.44 & 0.65 & 2.12 & 0.46 & 1.60 & 0.32 \\
& 1.68 & 1.04 & 0.50 & 0.78 & 0.35 & 0.62 & 2.10 & 0.47 & 1.59 & 0.30 \\
& 1.33 & 0.87 & 0.40 & 0.61 & 0.27 & 0.65 & 2.17 & 0.45 & 1.56 & 0.34 \\
& 1.07 & 0.70 & 0.33 & 0.45 & 0.23 & 0.66 & 2.15 & 0.42 & 1.63 & 0.29 \\
& 0.84 & 0.65 & 0.30 & 0.22 & 0.22 & 0.78 & 2.19 & 0.26 & 1.87 & 0.24 \\
& 0.61 & 0.66 & 0.32 & 0.04 & 0.14 & 1.08 & 2.08 & 0.06 & 1.70 & 0.55
\end{tabular}

Sulcogirtyoceras sp.

\begin{tabular}{|c|c|c|c|c|c|c|c|c|c|c|}
\hline MB.C.13215.2 & 12.90 & 6.20 & 5.00 & 4.30 & 3.00 & 0.48 & 1.24 & 0.33 & 1.71 & 0.40 \\
\hline \multicolumn{11}{|c|}{ Metadimorphoceras anguinosum $\mathrm{n}$. sp. } \\
\hline MB.C.13233.1 & 18.90 & 8.60 & 11.60 & 0.20 & 7.30 & 0.45 & 0.74 & 0.01 & 2.65 & 0.37 \\
\hline MB.C.13216.1 & 11.30 & 7.80 & 6.60 & 0.40 & 4.10 & 0.69 & 1.17 & 0.04 & 2.45 & 0.38 \\
\hline MB.C.13216.2 & 8.80 & 5.20 & 5.00 & 0.20 & 3.10 & 0.59 & 1.05 & 0.02 & 2.37 & 0.38 \\
\hline \multirow[t]{9}{*}{ MB.C. 13272.1} & 12.16 & 6.77 & 7.29 & 0.20 & 4.39 & 0.56 & 0.93 & 0.02 & 2.45 & 0.40 \\
\hline & 7.77 & 4.97 & 4.68 & 0.21 & 2.77 & 0.64 & 1.06 & 0.03 & 2.41 & 0.41 \\
\hline & 5.00 & 3.41 & 2.89 & 0.28 & 1.70 & 0.68 & 1.18 & 0.05 & 2.30 & 0.41 \\
\hline & 3.30 & 2.40 & 1.84 & 0.19 & 1.04 & 0.73 & 1.30 & 0.06 & 2.14 & 0.43 \\
\hline & 2.26 & 1.79 & 1.27 & 0.13 & 0.62 & 0.79 & 1.41 & 0.06 & 1.90 & 0.51 \\
\hline & 1.64 & 1.35 & 0.85 & 0.17 & 0.38 & 0.82 & 1.58 & 0.11 & 1.71 & 0.55 \\
\hline & 1.25 & 1.06 & 0.61 & 0.19 & 0.28 & 0.85 & 1.74 & 0.15 & 1.67 & 0.54 \\
\hline & 0.97 & 0.80 & 0.45 & 0.19 & 0.25 & 0.83 & 1.79 & 0.20 & 1.79 & 0.45 \\
\hline & 0.73 & 0.56 & 0.33 & 0.14 & 0.18 & 0.77 & 1.68 & 0.19 & 1.80 & 0.44 \\
\hline
\end{tabular}

Metadimorphoceras hodsoni Moore, 1958

\begin{tabular}{lrlllllllll} 
MB.C.13201.1 & 12.70 & 7.00 & 7.50 & 0.20 & 4.60 & 0.55 & 0.94 & 0.02 & 2.45 & 0.39 \\
\hline MB.C.13270.1 & 12.60 & 6.70 & 7.60 & 0.20 & 4.60 & 0.53 & 0.88 & 0.01 & 2.46 & 0.40 \\
\hline MB.C.13270.2 & 11.93 & 6.55 & 6.82 & 0.53 & 4.37 & 0.55 & 0.96 & 0.04 & 2.49 & 0.36 \\
& 7.56 & 4.77 & 4.58 & 0.09 & 2.73 & 0.63 & 1.04 & 0.01 & 2.46 & 0.40 \\
& 4.82 & 3.22 & 2.89 & 0.08 & 1.66 & 0.67 & 1.12 & 0.02 & 2.33 & 0.42 \\
& 3.16 & 2.25 & 1.86 & - & 1.06 & 0.71 & 1.21 & - & 2.26 & 0.43 \\
\hline MB.C.13270.3 & 9.02 & 5.55 & 5.46 & 0.14 & 3.36 & 0.61 & 1.02 & 0.01 & 2.54 & 0.38 \\
& 5.66 & 3.92 & 3.43 & 0.04 & 2.06 & 0.69 & 1.14 & 0.01 & 2.48 & 0.40 \\
& 3.59 & 2.57 & 2.19 & 0.04 & 1.19 & 0.71 & 1.17 & 0.01 & 2.24 & 0.46 \\
& 2.40 & 1.77 & 1.37 & - & 0.76 & 0.74 & 1.30 & - & 2.13 & 0.45
\end{tabular}

Goniatites crenistria Phillips, 1836

\begin{tabular}{lrlllllllll} 
MB.C.13256.3 & 120.10 & 58.20 & 59.30 & 18.60 & - & 0.48 & 0.98 & 0.16 & - & - \\
MB.C.13256.2 & 93.30 & 45.10 & 46.20 & 14.70 & 25.80 & 0.48 & 0.98 & 0.16 & 1.91 & 0.44 \\
\hline
\end{tabular}


B. (continued)

\begin{tabular}{|c|c|c|c|c|c|c|c|c|c|c|}
\hline & $\mathrm{dm}$ & ww & wh & uw & ah & ww/dm & ww/wh & $\mathrm{uw} / \mathrm{dm}$ & WER & IZW \\
\hline MB.C.13254.1 & 86.50 & 46.70 & 44.40 & 12.70 & 22.40 & 0.54 & 1.05 & 0.15 & 1.82 & 0.50 \\
\hline MB.C. 13254.2 & 68.20 & 40.20 & 35.80 & 8.20 & 16.90 & 0.59 & 1.12 & 0.12 & 1.77 & 0.53 \\
\hline MB.C.13254.3 & 64.10 & 38.10 & 30.50 & 9.70 & 16.20 & 0.59 & 1.25 & 0.15 & 1.79 & 0.47 \\
\hline \multirow[t]{3}{*}{ MB.C. 13254.4} & 79.84 & 45.37 & 41.41 & 9.15 & 20.60 & 0.57 & 1.10 & 0.11 & 1.82 & 0.50 \\
\hline & 59.25 & 36.33 & 29.29 & 7.41 & 14.36 & 0.61 & 1.24 & 0.13 & 1.74 & 0.51 \\
\hline & 44.88 & 30.85 & 22.54 & - & 9.52 & 0.69 & 1.37 & - & 1.61 & 0.58 \\
\hline \multirow[t]{6}{*}{ MB.C.13256.1 } & 59.00 & 34.70 & 29.18 & 8.28 & 14.22 & 0.59 & 1.19 & 0.14 & 1.74 & 0.51 \\
\hline & 44.78 & 28.77 & 21.54 & 6.41 & 10.16 & 0.64 & 1.34 & 0.14 & 1.67 & 0.53 \\
\hline & 34.63 & 24.43 & 16.83 & 4.34 & 7.03 & 0.71 & 1.45 & 0.13 & 1.57 & 0.58 \\
\hline & 27.59 & 20.09 & 13.45 & 3.17 & 4.85 & 0.73 & 1.49 & 0.11 & 1.47 & 0.64 \\
\hline & 22.75 & 17.66 & 10.97 & 2.29 & 4.19 & 0.78 & 1.61 & 0.10 & 1.50 & 0.62 \\
\hline & 18.55 & 13.73 & 9.48 & - & 3.37 & 0.74 & 1.45 & - & 1.49 & 0.64 \\
\hline \multicolumn{11}{|c|}{ Goniatites globostriatus (Schmidt, 1925) } \\
\hline MB.C.13255.1 & 98.00 & 52.00 & 44.80 & 13.70 & 18.80 & 0.53 & 1.16 & 0.14 & 1.53 & 0.58 \\
\hline MB.C. 13255.3 & 63.40 & 41.10 & 32.40 & 7.50 & - & 0.65 & 1.27 & 0.12 & - & - \\
\hline \multicolumn{11}{|c|}{ Arnsbergites sphaericostriatus (Bisat, 1924) } \\
\hline MB.C.13290.1 & 37.40 & 26.70 & 17.20 & 5.30 & 7.20 & 0.71 & 1.55 & 0.14 & 1.53 & 0.58 \\
\hline MB.C.13283 & 32.60 & 23.00 & 15.40 & 4.40 & 6.50 & 0.70 & 1.49 & 0.13 & 1.56 & 0.58 \\
\hline MB.C.13290.2 & 24.80 & 19.10 & 13.20 & 2.60 & - & 0.77 & 1.45 & 0.10 & - & - \\
\hline MB.C.13234 & 9.90 & 9.40 & 4.10 & 2.40 & 2.10 & 0.95 & 2.33 & 0.24 & 1.60 & 0.49 \\
\hline \multirow[t]{13}{*}{ MB.C.13234 } & 10.06 & 9.25 & 4.40 & 2.31 & 1.96 & 0.92 & 2.11 & 0.23 & 1.54 & 0.55 \\
\hline & 8.10 & 7.41 & 3.36 & 2.16 & 1.51 & 0.92 & 2.21 & 0.27 & 1.51 & 0.55 \\
\hline & 6.58 & 6.11 & 2.59 & 2.14 & 1.23 & 0.93 & 2.36 & 0.33 & 1.51 & 0.52 \\
\hline & 5.36 & 4.87 & 1.86 & 2.02 & 0.97 & 0.91 & 2.62 & 0.38 & 1.49 & 0.48 \\
\hline & 4.39 & 3.99 & 1.48 & 1.78 & 0.82 & 0.91 & 2.70 & 0.41 & 1.51 & 0.45 \\
\hline & 3.57 & 3.14 & 1.13 & 1.56 & 0.66 & 0.88 & 2.78 & 0.44 & 1.50 & 0.42 \\
\hline & 2.91 & 2.50 & 0.88 & 1.35 & 0.53 & 0.86 & 2.85 & 0.46 & 1.49 & 0.40 \\
\hline & 2.39 & 1.91 & 0.69 & 1.14 & 0.44 & 0.80 & 2.78 & 0.48 & 1.51 & 0.35 \\
\hline & 1.94 & 1.45 & 0.56 & 0.91 & 0.36 & 0.75 & 2.58 & 0.47 & 1.50 & 0.37 \\
\hline & 1.59 & 1.19 & 0.47 & 0.71 & 0.28 & 0.75 & 2.52 & 0.45 & 1.48 & 0.40 \\
\hline & 1.30 & 0.91 & 0.41 & 0.52 & 0.26 & 0.70 & 2.24 & 0.40 & 1.56 & 0.36 \\
\hline & 1.04 & 0.75 & 0.38 & 0.38 & 0.24 & 0.72 & 1.97 & 0.37 & 1.68 & 0.37 \\
\hline & 0.80 & 0.62 & 0.28 & - & 0.18 & 0.77 & 2.21 & - & 1.68 & 0.34 \\
\hline \multicolumn{11}{|c|}{ Arnsbergites ferrus n. sp. } \\
\hline MB.C.13291.1 & 30.80 & 24.80 & 14.80 & 4.80 & 6.00 & 0.81 & 1.67 & 0.16 & 1.54 & 0.60 \\
\hline MB.C.13218.4 & 16.30 & 14.20 & 7.20 & 4.00 & 3.40 & 0.87 & 1.97 & 0.25 & 1.59 & 0.53 \\
\hline MB.C.13218.1 & 11.10 & 10.40 & 4.40 & 3.40 & 2.20 & 0.94 & 2.35 & 0.31 & 1.56 & 0.50 \\
\hline \multirow[t]{15}{*}{ MB.C.13274.1 } & 15.76 & 15.40 & 7.15 & 2.98 & 2.74 & 0.98 & 2.15 & 0.19 & 1.46 & 0.62 \\
\hline & 13.03 & 12.17 & 5.64 & 2.83 & 2.46 & 0.93 & 2.16 & 0.22 & 1.52 & 0.56 \\
\hline & 10.56 & 10.15 & 4.56 & 2.57 & 2.08 & 0.96 & 2.23 & 0.24 & 1.55 & 0.54 \\
\hline & 8.48 & 8.12 & 3.43 & 2.34 & 1.56 & 0.96 & 2.36 & 0.28 & 1.50 & 0.55 \\
\hline & 6.93 & 6.63 & 2.71 & 2.23 & 1.26 & 0.96 & 2.45 & 0.32 & 1.49 & 0.53 \\
\hline & 5.67 & 5.05 & 1.99 & 2.14 & 1.07 & 0.89 & 2.54 & 0.38 & 1.52 & 0.46 \\
\hline & 4.60 & 4.24 & 1.54 & 1.85 & 0.79 & 0.92 & 2.76 & 0.40 & 1.46 & 0.48 \\
\hline & 3.81 & 3.20 & 1.21 & 1.58 & 0.66 & 0.84 & 2.65 & 0.42 & 1.47 & 0.45 \\
\hline & 3.14 & 2.70 & 1.02 & 1.32 & 0.60 & 0.86 & 2.66 & 0.42 & 1.53 & 0.41 \\
\hline & 2.54 & 2.04 & 0.81 & 1.08 & 0.50 & 0.80 & 2.54 & 0.42 & 1.55 & 0.38 \\
\hline & 2.04 & 1.54 & 0.66 & 0.85 & 0.42 & 0.76 & 2.34 & 0.42 & 1.58 & 0.36 \\
\hline & 1.62 & 1.18 & 0.53 & 0.64 & 0.33 & 0.73 & 2.24 & 0.39 & 1.58 & 0.37 \\
\hline & 1.29 & 1.00 & 0.46 & 0.41 & 0.30 & 0.78 & 2.18 & 0.32 & 1.68 & 0.36 \\
\hline & 0.99 & 0.75 & 0.42 & 0.24 & 0.27 & 0.76 & 1.78 & 0.24 & 1.86 & 0.37 \\
\hline & 0.73 & 0.73 & 0.33 & 0.12 & 0.19 & 1.00 & 2.17 & 0.17 & 1.83 & 0.43 \\
\hline \multirow[t]{2}{*}{ MB.C.13218.2 } & 12.63 & 11.15 & 4.87 & 3.89 & 2.23 & 0.88 & 2.29 & 0.31 & 1.48 & 0.54 \\
\hline & 10.39 & 9.36 & 3.87 & 3.48 & 1.80 & 0.90 & 2.42 & 0.33 & 1.46 & 0.53 \\
\hline
\end{tabular}


B. (continued)

\begin{tabular}{|c|c|c|c|c|c|c|c|c|c|c|}
\hline & $\mathrm{dm}$ & ww & wh & uw & ah & $w w / d m$ & ww/wh & $\mathrm{uw} / \mathrm{dm}$ & WER & IZW \\
\hline & 8.59 & 7.92 & 3.05 & 3.20 & 1.65 & 0.92 & 2.60 & 0.37 & 1.53 & 0.46 \\
\hline & 6.95 & 6.13 & 2.34 & 2.86 & 1.18 & 0.88 & 2.62 & 0.41 & 1.45 & 0.50 \\
\hline & 5.77 & 5.17 & 1.74 & 2.58 & 1.04 & 0.90 & 2.97 & 0.45 & 1.49 & 0.40 \\
\hline & 4.73 & 4.32 & 1.45 & 2.14 & 0.82 & 0.91 & 2.98 & 0.45 & 1.46 & 0.43 \\
\hline & 3.91 & 3.31 & 1.14 & 1.83 & 0.74 & 0.85 & 2.91 & 0.47 & 1.52 & 0.35 \\
\hline & 3.16 & 2.37 & 0.94 & 1.46 & 0.62 & 0.75 & 2.53 & 0.46 & 1.54 & 0.34 \\
\hline & 2.55 & 1.86 & 0.77 & 1.04 & 0.48 & 0.73 & 2.42 & 0.41 & 1.52 & 0.37 \\
\hline & 2.07 & 1.42 & 0.74 & 0.73 & 0.47 & 0.69 & 1.93 & 0.36 & 1.67 & 0.37 \\
\hline & 1.60 & 1.19 & 0.60 & 0.54 & 0.37 & 0.75 & 2.00 & 0.34 & 1.70 & 0.37 \\
\hline & 1.23 & 0.84 & 0.47 & 0.38 & 0.32 & 0.69 & 1.80 & 0.31 & 1.81 & 0.32 \\
\hline \multicolumn{11}{|c|}{ Arnsbergites proiecturus n. sp. } \\
\hline MB.C.13219.1 & 18.60 & 17.10 & 6.90 & 5.80 & - & 0.92 & 2.48 & 0.31 & - & - \\
\hline MB.C. 13219.2 & 11.70 & 10.40 & 5.30 & 4.00 & 2.20 & 0.89 & 1.96 & 0.35 & 1.51 & 0.59 \\
\hline \multirow[t]{14}{*}{ MB.C.13219.3 } & 11.25 & 9.66 & 4.10 & 4.07 & 2.13 & 0.86 & 2.35 & 0.36 & 1.52 & 0.48 \\
\hline & 9.12 & 7.74 & 3.08 & 3.65 & 1.53 & 0.85 & 2.51 & 0.40 & 1.44 & 0.51 \\
\hline & 7.59 & 6.42 & 2.38 & 3.14 & 1.26 & 0.85 & 2.69 & 0.41 & 1.44 & 0.47 \\
\hline & 6.33 & 5.32 & 2.07 & 2.72 & 1.16 & 0.84 & 2.57 & 0.43 & 1.50 & 0.44 \\
\hline & 5.17 & 4.13 & 1.54 & 2.35 & 0.87 & 0.80 & 2.68 & 0.45 & 1.45 & 0.43 \\
\hline & 4.30 & 3.22 & 1.28 & 1.94 & 0.74 & 0.75 & 2.51 & 0.45 & 1.46 & 0.42 \\
\hline & 3.55 & 2.50 & 1.07 & 1.65 & 0.59 & 0.70 & 2.33 & 0.46 & 1.44 & 0.45 \\
\hline & 2.96 & 1.79 & 0.83 & 1.45 & 0.52 & 0.60 & 2.15 & 0.49 & 1.47 & 0.38 \\
\hline & 2.44 & 1.43 & 0.68 & 1.18 & 0.44 & 0.58 & 2.09 & 0.48 & 1.49 & 0.36 \\
\hline & 2.00 & 1.00 & 0.58 & 0.91 & 0.36 & 0.50 & 1.72 & 0.46 & 1.49 & 0.38 \\
\hline & 1.64 & 0.86 & 0.51 & 0.73 & 0.32 & 0.52 & 1.69 & 0.45 & 1.54 & 0.37 \\
\hline & 1.32 & 0.66 & 0.40 & 0.53 & 0.28 & 0.49 & 1.63 & 0.40 & 1.60 & 0.31 \\
\hline & 1.05 & 0.63 & 0.39 & 0.26 & 0.26 & 0.60 & 1.60 & 0.25 & 1.78 & 0.33 \\
\hline & 0.79 & 0.62 & 0.40 & 0.06 & 0.22 & 0.79 & 1.55 & 0.08 & 1.90 & 0.46 \\
\hline \multicolumn{11}{|c|}{ Arnsbergites rufus n. sp. } \\
\hline MB.C. 13285.1 & 37.60 & 23.00 & 18.60 & 4.10 & 7.50 & 0.61 & 1.24 & 0.11 & 1.56 & 0.60 \\
\hline MB.C. 13285.2 & 29.40 & 18.80 & 14.60 & 2.90 & 5.40 & 0.64 & 1.29 & 0.10 & 1.50 & 0.63 \\
\hline MB.C.13285.4 & 23.60 & 16.50 & 12.10 & 2.90 & 4.70 & 0.70 & 1.36 & 0.12 & 1.56 & 0.61 \\
\hline \multirow[t]{2}{*}{ MB.C. 13285.3} & 26.65 & 19.67 & 13.39 & 1.05 & 5.71 & 0.74 & 1.47 & 0.04 & 1.62 & 0.57 \\
\hline & 20.94 & 17.34 & 12.21 & - & 4.63 & 0.83 & 1.42 & - & 1.65 & 0.62 \\
\hline \multicolumn{11}{|c|}{ Hibernicoceras carraunense Moore \& Hodson, 1958} \\
\hline MB.C.13209.1 & 32.80 & 22.50 & 15.30 & 5.40 & 7.40 & 0.69 & 1.47 & 0.16 & 1.67 & 0.52 \\
\hline MB.C. 13209.2 & 22.90 & 17.60 & 9.80 & 4.80 & 4.80 & 0.77 & 1.79 & 0.21 & 1.60 & 0.51 \\
\hline MB.C.13236.3 & 8.80 & 7.50 & 4.10 & 2.20 & 1.80 & 0.85 & 1.82 & 0.25 & 1.56 & 0.57 \\
\hline \multirow[t]{11}{*}{ MB.C.13236.1 } & 21.53 & 15.86 & 10.13 & 3.23 & 4.15 & 0.74 & 1.57 & 0.15 & 1.53 & 0.59 \\
\hline & 17.38 & 13.93 & 8.17 & 2.99 & 3.27 & 0.80 & 1.70 & 0.17 & 1.52 & 0.60 \\
\hline & 14.12 & 12.03 & 6.21 & 3.02 & 2.69 & 0.85 & 1.94 & 0.21 & 1.53 & 0.57 \\
\hline & 11.43 & 9.51 & 4.89 & 2.64 & 2.03 & 0.83 & 1.95 & 0.23 & 1.48 & 0.58 \\
\hline & 9.39 & 8.32 & 3.90 & 2.61 & 1.81 & 0.89 & 2.14 & 0.28 & 1.53 & 0.54 \\
\hline & 7.59 & 6.63 & 2.89 & 2.37 & 1.47 & 0.87 & 2.30 & 0.31 & 1.54 & 0.49 \\
\hline & 6.12 & 5.46 & 2.33 & 1.99 & 1.16 & 0.89 & 2.34 & 0.32 & 1.52 & 0.50 \\
\hline & 4.96 & 4.30 & 1.80 & 1.73 & 0.97 & 0.87 & 2.39 & 0.35 & 1.54 & 0.46 \\
\hline & 3.99 & 3.47 & 1.42 & 1.48 & 0.79 & 0.87 & 2.44 & 0.37 & 1.55 & 0.45 \\
\hline & 3.20 & 2.67 & 1.09 & 1.24 & 0.65 & 0.83 & 2.45 & 0.39 & 1.57 & 0.40 \\
\hline & 2.55 & 2.04 & 0.88 & - & 0.51 & 0.80 & 2.32 & - & 1.56 & 0.42 \\
\hline \multirow[t]{6}{*}{ MB.C.13236.2 } & 21.18 & 15.01 & 9.38 & 4.31 & 4.04 & 0.71 & 1.60 & 0.20 & 1.53 & 0.57 \\
\hline & 17.14 & 13.26 & 7.49 & 3.58 & 3.11 & 0.77 & 1.77 & 0.21 & 1.49 & 0.58 \\
\hline & 14.03 & 10.91 & 6.07 & 3.18 & 2.56 & 0.78 & 1.80 & 0.23 & 1.50 & 0.58 \\
\hline & 11.47 & 9.32 & 4.78 & 2.94 & 2.14 & 0.81 & 1.95 & 0.26 & 1.51 & 0.55 \\
\hline & 9.33 & 7.76 & 3.75 & 2.66 & 1.64 & 0.83 & 2.07 & 0.28 & 1.47 & 0.56 \\
\hline & 7.70 & 6.35 & 2.93 & 2.54 & 1.41 & 0.82 & 2.17 & 0.33 & 1.50 & 0.52 \\
\hline
\end{tabular}




\begin{tabular}{rcccccccccc}
\hline $\mathrm{dm}$ & ww & wh & uw & ah & ww/dm & ww/wh & uw/dm & WER & IZW \\
\hline 6.29 & 5.30 & 2.23 & 2.32 & 1.12 & 0.84 & 2.37 & 0.37 & 1.48 & 0.50 \\
5.17 & 4.36 & 1.74 & 2.10 & 0.95 & 0.84 & 2.51 & 0.41 & 1.50 & 0.45 \\
4.22 & 3.47 & 1.33 & 1.80 & 0.77 & 0.82 & 2.61 & 0.43 & 1.50 & 0.42 \\
3.45 & 2.78 & 1.08 & 1.52 & 0.64 & 0.81 & 2.58 & 0.44 & 1.50 & 0.41 \\
2.81 & 2.10 & 0.85 & 1.31 & 0.54 & 0.75 & 2.48 & 0.47 & 1.54 & 0.36
\end{tabular}

Hibernicoceras touissitense n. sp.

\begin{tabular}{|c|c|c|c|c|c|c|c|c|c|c|}
\hline MB.C.13237.1 & 30.40 & 17.00 & 15.10 & 4.20 & 7.30 & 0.56 & 1.13 & 0.14 & 1.72 & 0.52 \\
\hline MB.C.13292.1 & 18.40 & 13.70 & 9.80 & 2.10 & 3.50 & 0.74 & 1.39 & 0.11 & 1.53 & 0.64 \\
\hline MB.C.13276.1 & 14.60 & 11.30 & 6.90 & 1.80 & 2.80 & 0.77 & 1.65 & 0.12 & 1.53 & 0.59 \\
\hline MB.C. 13276.2 & 12.70 & 9.60 & 5.30 & 2.40 & 2.20 & 0.75 & 1.80 & 0.19 & 1.47 & 0.58 \\
\hline \multirow[t]{15}{*}{ MB.C.13237.2 } & 15.32 & 11.48 & 7.27 & 2.13 & 3.05 & 0.75 & 1.58 & 0.14 & 1.56 & 0.58 \\
\hline & 12.28 & 9.89 & 5.93 & 2.01 & 2.60 & 0.81 & 1.67 & 0.16 & 1.61 & 0.56 \\
\hline & 9.67 & 8.22 & 4.34 & 1.90 & 1.80 & 0.85 & 1.89 & 0.20 & 1.51 & 0.59 \\
\hline & 7.88 & 6.92 & 3.43 & 1.85 & 1.54 & 0.88 & 2.01 & 0.24 & 1.54 & 0.55 \\
\hline & 6.34 & 5.60 & 2.59 & 1.91 & 1.17 & 0.88 & 2.16 & 0.30 & 1.50 & 0.55 \\
\hline & 5.18 & 4.55 & 1.85 & 1.99 & 0.91 & 0.88 & 2.46 & 0.39 & 1.47 & 0.51 \\
\hline & 4.27 & 3.66 & 1.34 & 1.87 & 0.74 & 0.86 & 2.74 & 0.44 & 1.47 & 0.44 \\
\hline & 3.53 & 2.88 & 1.07 & 1.67 & 0.65 & 0.82 & 2.70 & 0.47 & 1.51 & 0.39 \\
\hline & 2.87 & 2.27 & 0.78 & 1.49 & 0.50 & 0.79 & 2.90 & 0.52 & 1.47 & 0.36 \\
\hline & 2.37 & 1.75 & 0.60 & 1.24 & 0.43 & 0.74 & 2.90 & 0.53 & 1.49 & 0.29 \\
\hline & 1.94 & 1.37 & 0.52 & 1.00 & 0.37 & 0.70 & 2.62 & 0.51 & 1.53 & 0.29 \\
\hline & 1.57 & 1.07 & 0.42 & 0.76 & 0.30 & 0.68 & 2.54 & 0.48 & 1.53 & 0.28 \\
\hline & 1.27 & 0.81 & 0.39 & 0.53 & 0.24 & 0.64 & 2.06 & 0.41 & 1.53 & 0.38 \\
\hline & 1.03 & 0.74 & 0.35 & 0.34 & 0.24 & 0.71 & 2.08 & 0.33 & 1.70 & 0.32 \\
\hline & 0.79 & 0.63 & 0.34 & 0.16 & 0.18 & 0.80 & 1.86 & 0.20 & 1.70 & 0.46 \\
\hline \multirow[t]{14}{*}{ MB.C.13237.3 } & 14.46 & 10.89 & 6.55 & 2.78 & 2.66 & 0.75 & 1.66 & 0.19 & 1.50 & 0.59 \\
\hline & 11.80 & 9.14 & 5.13 & 2.35 & 1.99 & 0.78 & 1.78 & 0.20 & 1.45 & 0.61 \\
\hline & 9.80 & 7.90 & 4.31 & 2.04 & 1.83 & 0.81 & 1.83 & 0.21 & 1.51 & 0.58 \\
\hline & 7.97 & 6.69 & 3.45 & 1.67 & 1.49 & 0.84 & 1.94 & 0.21 & 1.51 & 0.57 \\
\hline & 6.49 & 5.46 & 2.85 & 1.51 & 1.39 & 0.84 & 1.91 & 0.23 & 1.62 & 0.51 \\
\hline & 5.10 & 4.35 & 2.13 & 1.51 & 1.05 & 0.85 & 2.05 & 0.30 & 1.58 & 0.51 \\
\hline & 4.05 & 3.49 & 1.47 & 1.52 & 0.80 & 0.86 & 2.38 & 0.37 & 1.56 & 0.45 \\
\hline & 3.25 & 2.59 & 1.07 & 1.41 & 0.64 & 0.80 & 2.42 & 0.43 & 1.55 & 0.41 \\
\hline & 2.61 & 2.03 & 0.77 & 1.25 & 0.50 & 0.77 & 2.62 & 0.48 & 1.53 & 0.35 \\
\hline & 2.11 & 1.51 & 0.59 & 1.06 & 0.43 & 0.71 & 2.54 & 0.50 & 1.58 & 0.27 \\
\hline & 1.68 & 1.21 & 0.46 & 0.85 & 0.32 & 0.72 & 2.62 & 0.51 & 1.53 & 0.30 \\
\hline & 1.36 & 0.91 & 0.36 & 0.61 & 0.26 & 0.67 & 2.50 & 0.45 & 1.53 & 0.29 \\
\hline & 1.10 & 0.78 & 0.38 & 0.45 & 0.26 & 0.71 & 2.06 & 0.41 & 1.73 & 0.30 \\
\hline & 0.83 & 0.67 & 0.27 & 0.27 & 0.20 & 0.81 & 2.47 & 0.33 & 1.72 & 0.28 \\
\hline \multicolumn{11}{|c|}{ Hibernicoceras artilobatum n. sp. } \\
\hline MB.C.13286 & 22.80 & 18.00 & 10.70 & 2.20 & 5.30 & 0.79 & 1.69 & 0.10 & 1.69 & 0.51 \\
\hline MB.C.13238.2 & 18.90 & 14.70 & 9.40 & 2.20 & 4.10 & 0.78 & 1.57 & 0.12 & 1.64 & 0.56 \\
\hline MB.C.13238.1 & 14.40 & 11.80 & 7.00 & 1.80 & 3.10 & 0.82 & 1.69 & 0.12 & 1.62 & 0.55 \\
\hline \multirow[t]{9}{*}{ MB.C.13277.1 } & 17.18 & 14.06 & 8.32 & 2.34 & 3.52 & 0.82 & 1.69 & 0.14 & 1.58 & 0.58 \\
\hline & 13.67 & 11.43 & 6.52 & 2.01 & 2.75 & 0.84 & 1.75 & 0.15 & 1.57 & 0.58 \\
\hline & 10.92 & 9.76 & 5.13 & 1.82 & 2.13 & 0.89 & 1.90 & 0.17 & 1.54 & 0.58 \\
\hline & 8.79 & 7.70 & 3.96 & 1.68 & 1.77 & 0.88 & 1.94 & 0.19 & 1.57 & 0.55 \\
\hline & 7.02 & 6.55 & 3.14 & 1.50 & 1.45 & 0.93 & 2.08 & 0.21 & 1.59 & 0.54 \\
\hline & 5.57 & 5.12 & 2.38 & 1.53 & 1.06 & 0.92 & 2.15 & 0.28 & 1.52 & 0.55 \\
\hline & 4.51 & 4.32 & 1.66 & 1.54 & 0.85 & 0.96 & 2.60 & 0.34 & 1.51 & 0.49 \\
\hline & 3.67 & 3.38 & 1.32 & 1.40 & 0.69 & 0.92 & 2.57 & 0.38 & 1.52 & 0.47 \\
\hline & 2.97 & 2.72 & 0.95 & 1.27 & 0.52 & 0.91 & 2.86 & 0.43 & 1.46 & 0.46 \\
\hline \multirow[t]{2}{*}{ MB.C. 13277.2} & 11.92 & 9.58 & 5.85 & 1.57 & 2.56 & 0.80 & 1.64 & 0.13 & 1.62 & 0.56 \\
\hline & 9.35 & 7.95 & 4.50 & 1.58 & 2.10 & 0.85 & 1.77 & 0.17 & 1.66 & 0.53 \\
\hline
\end{tabular}


B. (continued)

\begin{tabular}{|c|c|c|c|c|c|c|c|c|c|c|}
\hline & $\mathrm{dm}$ & ww & wh & uw & ah & $w w / d m$ & ww/wh & $\mathrm{uw} / \mathrm{dm}$ & WER & IZW \\
\hline & 7.26 & 6.45 & 3.28 & 1.68 & 1.63 & 0.89 & 1.96 & 0.23 & 1.67 & 0.50 \\
\hline & 5.62 & 4.83 & 2.30 & 1.88 & 1.10 & 0.86 & 2.10 & 0.33 & 1.55 & 0.52 \\
\hline & 4.52 & 3.85 & 1.45 & 1.82 & 0.74 & 0.85 & 2.66 & 0.40 & 1.43 & 0.49 \\
\hline & 3.78 & 3.04 & 1.25 & 1.62 & 0.71 & 0.80 & 2.43 & 0.43 & 1.51 & 0.44 \\
\hline & 3.07 & 2.50 & 0.91 & 1.52 & 0.59 & 0.81 & 2.75 & 0.49 & 1.53 & 0.35 \\
\hline & 2.48 & 1.88 & 0.65 & 1.23 & 0.40 & 0.76 & 2.92 & 0.49 & 1.43 & 0.37 \\
\hline & 2.08 & 1.61 & 0.61 & 1.03 & 0.40 & 0.78 & 2.64 & 0.50 & 1.54 & 0.34 \\
\hline & 1.68 & 1.19 & 0.44 & 0.82 & 0.31 & 0.71 & 2.73 & 0.49 & 1.50 & 0.30 \\
\hline & 1.37 & 1.00 & 0.43 & 0.63 & 0.29 & 0.73 & 2.36 & 0.46 & 1.60 & 0.32 \\
\hline \multicolumn{11}{|c|}{ Paraglyphioceras rudis (Moore \& Hodson, 1958) } \\
\hline MB.C.13278.1 & 15.60 & 11.50 & 7.50 & 1.50 & 4.20 & 0.70 & 1.53 & 0.09 & 1.88 & 0.44 \\
\hline MB.C. 13278.3 & 10.00 & 8.00 & 5.20 & 0.80 & 2.50 & 0.80 & 1.55 & 0.08 & 1.78 & 0.52 \\
\hline MB.C. 13278.2 & 9.60 & 7.80 & 5.10 & 0.90 & 2.60 & 0.80 & 1.55 & 0.09 & 1.88 & 0.48 \\
\hline \multirow[t]{12}{*}{ MB.C.13239.1 } & 18.15 & 12.94 & 9.91 & 0.86 & 4.46 & 0.71 & 1.31 & 0.05 & 1.76 & 0.55 \\
\hline & 13.69 & 10.54 & 7.38 & 0.76 & 3.49 & 0.77 & 1.43 & 0.06 & 1.80 & 0.53 \\
\hline & 10.20 & 8.41 & 5.56 & 0.67 & 2.65 & 0.82 & 1.51 & 0.07 & 1.82 & 0.52 \\
\hline & 7.56 & 6.54 & 3.97 & 0.80 & 1.95 & 0.86 & 1.64 & 0.11 & 1.82 & 0.51 \\
\hline & 5.60 & 4.84 & 2.78 & 0.96 & 1.43 & 0.86 & 1.74 & 0.17 & 1.81 & 0.49 \\
\hline & 4.17 & 3.69 & 1.86 & 1.05 & 0.98 & 0.88 & 1.98 & 0.25 & 1.71 & 0.47 \\
\hline & 3.19 & 2.67 & 1.26 & 1.07 & 0.65 & 0.84 & 2.12 & 0.34 & 1.58 & 0.48 \\
\hline & 2.54 & 1.97 & 0.86 & 1.00 & 0.54 & 0.78 & 2.30 & 0.40 & 1.61 & 0.37 \\
\hline & 2.00 & 1.51 & 0.68 & 0.84 & 0.46 & 0.76 & 2.23 & 0.42 & 1.69 & 0.32 \\
\hline & 1.54 & 1.20 & 0.48 & 0.63 & 0.34 & 0.78 & 2.50 & 0.41 & 1.65 & 0.29 \\
\hline & 1.20 & 0.95 & 0.42 & 0.41 & 0.31 & 0.79 & 2.25 & 0.35 & 1.82 & 0.26 \\
\hline & 0.88 & 0.81 & 0.35 & 0.21 & 0.21 & 0.92 & 2.28 & 0.23 & 1.73 & 0.41 \\
\hline \multirow[t]{13}{*}{ MB.C.13223.1 } & 19.38 & 13.81 & 9.67 & 2.02 & 4.52 & 0.71 & 1.43 & 0.10 & 1.70 & 0.53 \\
\hline & 14.86 & 11.29 & 7.69 & 1.37 & 3.72 & 0.76 & 1.47 & 0.09 & 1.78 & 0.52 \\
\hline & 11.14 & 9.06 & 5.80 & 0.91 & 2.68 & 0.81 & 1.56 & 0.08 & 1.73 & 0.54 \\
\hline & 8.46 & 7.13 & 4.43 & 0.85 & 2.02 & 0.84 & 1.61 & 0.10 & 1.73 & 0.54 \\
\hline & 6.44 & 5.32 & 3.19 & 1.10 & 1.65 & 0.83 & 1.67 & 0.17 & 1.81 & 0.48 \\
\hline & 4.79 & 3.95 & 2.15 & 1.18 & 1.12 & 0.82 & 1.84 & 0.25 & 1.70 & 0.48 \\
\hline & 3.67 & 3.13 & 1.46 & 1.29 & 0.85 & 0.85 & 2.14 & 0.35 & 1.70 & 0.42 \\
\hline & 2.82 & 2.20 & 0.92 & 1.18 & 0.55 & 0.78 & 2.39 & 0.42 & 1.54 & 0.40 \\
\hline & 2.27 & 1.72 & 0.73 & 1.00 & 0.45 & 0.76 & 2.37 & 0.44 & 1.56 & 0.38 \\
\hline & 1.82 & 1.33 & 0.55 & 0.81 & 0.36 & 0.73 & 2.40 & 0.45 & 1.55 & 0.35 \\
\hline & 1.46 & 1.08 & 0.45 & 0.58 & 0.29 & 0.74 & 2.39 & 0.39 & 1.57 & 0.35 \\
\hline & 1.17 & 0.91 & 0.43 & 0.43 & 0.28 & 0.78 & 2.11 & 0.36 & 1.73 & 0.35 \\
\hline & 0.89 & 0.70 & 0.31 & 0.33 & 0.21 & 0.79 & 2.25 & 0.37 & 1.73 & 0.32 \\
\hline \multicolumn{11}{|c|}{ Paraglyphioceras celeris n. sp. } \\
\hline MB.C.13279.6 & 22.50 & - & - & 1.20 & 7.20 & - & - & 0.06 & 2.17 & - \\
\hline MB.C.13279.1 & 15.70 & 11.30 & 9.20 & 1.30 & 4.70 & 0.72 & 1.23 & 0.08 & 2.02 & 0.49 \\
\hline MB.C.13279.2 & 15.20 & 11.20 & 8.70 & 1.30 & 4.60 & 0.74 & 1.29 & 0.09 & 2.04 & 0.48 \\
\hline MB.C. 13279.3 & 13.70 & 9.30 & 7.70 & 0.40 & 4.10 & 0.68 & 1.21 & 0.03 & 2.05 & 0.46 \\
\hline MB.C.13224.1 & 11.00 & 8.30 & 6.40 & 0.80 & 3.40 & 0.76 & 1.30 & 0.08 & 2.08 & 0.48 \\
\hline \multirow[t]{9}{*}{ MB.C. 13279.4} & 16.74 & 11.56 & 9.22 & 0.89 & 4.76 & 0.69 & 1.25 & 0.05 & 1.95 & 0.48 \\
\hline & 11.98 & 9.02 & 6.64 & 0.69 & 3.32 & 0.75 & 1.36 & 0.06 & 1.91 & 0.50 \\
\hline & 8.66 & 7.17 & 4.66 & 0.75 & 2.28 & 0.83 & 1.54 & 0.09 & 1.84 & 0.51 \\
\hline & 6.39 & 5.23 & 3.25 & 0.85 & 1.61 & 0.82 & 1.61 & 0.13 & 1.79 & 0.50 \\
\hline & 4.78 & 4.13 & 2.28 & 0.94 & 1.11 & 0.86 & 1.81 & 0.20 & 1.69 & 0.52 \\
\hline & 3.67 & 3.04 & 1.55 & 1.03 & 0.82 & 0.83 & 1.96 & 0.28 & 1.66 & 0.47 \\
\hline & 2.85 & 2.50 & 1.09 & 0.99 & 0.64 & 0.88 & 2.29 & 0.35 & 1.66 & 0.42 \\
\hline & 2.22 & 1.81 & 0.77 & 0.85 & 0.47 & 0.82 & 2.36 & 0.38 & 1.61 & 0.39 \\
\hline & 1.74 & 1.47 & 0.60 & 0.66 & 0.37 & 0.84 & 2.44 & 0.38 & 1.60 & 0.39 \\
\hline \multirow[t]{2}{*}{ MB.C.13279.5 } & 14.89 & 10.47 & 8.32 & 0.79 & 4.55 & 0.70 & 1.26 & 0.05 & 2.07 & 0.45 \\
\hline & 10.34 & 8.23 & 5.77 & 0.85 & 3.05 & 0.80 & 1.43 & 0.08 & 2.01 & 0.47 \\
\hline
\end{tabular}




\begin{tabular}{|c|c|c|c|c|c|c|c|c|c|c|}
\hline & $\mathrm{dm}$ & ww & wh & uw & ah & $w w / d m$ & ww/wh & $\mathrm{uw} / \mathrm{dm}$ & WER & IZW \\
\hline & 7.29 & 6.37 & 3.73 & 1.09 & 1.90 & 0.87 & 1.71 & 0.15 & 1.83 & 0.49 \\
\hline & 5.39 & 4.75 & 2.47 & 1.28 & 1.26 & 0.88 & 1.92 & 0.24 & 1.70 & 0.49 \\
\hline & 4.13 & 3.54 & 1.64 & 1.36 & 0.84 & 0.86 & 2.16 & 0.33 & 1.57 & 0.49 \\
\hline & 3.29 & 2.67 & 1.13 & 1.28 & 0.61 & 0.81 & 2.37 & 0.39 & 1.50 & 0.46 \\
\hline & 2.68 & 2.19 & 0.89 & 1.13 & 0.52 & 0.82 & 2.47 & 0.42 & 1.54 & 0.41 \\
\hline & 2.16 & 1.67 & 0.67 & 0.94 & 0.41 & 0.78 & 2.50 & 0.44 & 1.53 & 0.39 \\
\hline & 1.75 & 1.33 & 0.55 & 0.74 & 0.38 & 0.76 & 2.44 & 0.42 & 1.64 & 0.30 \\
\hline & 1.37 & 1.03 & 0.47 & 0.52 & 0.32 & 0.75 & 2.21 & 0.38 & 1.70 & 0.32 \\
\hline & 1.05 & 0.88 & 0.38 & 0.29 & 0.24 & 0.84 & 2.29 & 0.28 & 1.67 & 0.38 \\
\hline & 0.81 & 0.64 & 0.37 & 0.06 & 0.23 & 0.78 & 1.70 & 0.07 & 1.93 & 0.39 \\
\hline \multicolumn{11}{|c|}{ Paraglyphioceras celeris n. sp. } \\
\hline MB.C.13279.6 & 22.50 & - & - & 1.20 & 7.20 & - & - & 0.06 & 2.17 & - \\
\hline MB.C.13279.1 & 15.70 & 11.30 & 9.20 & 1.30 & 4.70 & 0.72 & 1.23 & 0.08 & 2.02 & 0.49 \\
\hline MB.C.13279.2 & 15.20 & 11.20 & 8.70 & 1.30 & 4.60 & 0.74 & 1.29 & 0.09 & 2.04 & 0.48 \\
\hline MB.C.13279.3 & 13.70 & 9.30 & 7.70 & 0.40 & 4.10 & 0.68 & 1.21 & 0.03 & 2.05 & 0.46 \\
\hline MB.C.13224.1 & 11.00 & 8.30 & 6.40 & 0.80 & 3.40 & 0.76 & 1.30 & 0.08 & 2.08 & 0.48 \\
\hline \multirow[t]{9}{*}{ MB.C.13279.4 } & 16.74 & 11.56 & 9.22 & 0.89 & 4.76 & 0.69 & 1.25 & 0.05 & 1.95 & 0.48 \\
\hline & 11.98 & 9.02 & 6.64 & 0.69 & 3.32 & 0.75 & 1.36 & 0.06 & 1.91 & 0.50 \\
\hline & 8.66 & 7.17 & 4.66 & 0.75 & 2.28 & 0.83 & 1.54 & 0.09 & 1.84 & 0.51 \\
\hline & 6.39 & 5.23 & 3.25 & 0.85 & 1.61 & 0.82 & 1.61 & 0.13 & 1.79 & 0.50 \\
\hline & 4.78 & 4.13 & 2.28 & 0.94 & 1.11 & 0.86 & 1.81 & 0.20 & 1.69 & 0.52 \\
\hline & 3.67 & 3.04 & 1.55 & 1.03 & 0.82 & 0.83 & 1.96 & 0.28 & 1.66 & 0.47 \\
\hline & 2.85 & 2.50 & 1.09 & 0.99 & 0.64 & 0.88 & 2.29 & 0.35 & 1.66 & 0.42 \\
\hline & 2.22 & 1.81 & 0.77 & 0.85 & 0.47 & 0.82 & 2.36 & 0.38 & 1.61 & 0.39 \\
\hline & 1.74 & 1.47 & 0.60 & 0.66 & 0.37 & 0.84 & 2.44 & 0.38 & 1.60 & 0.39 \\
\hline \multirow[t]{12}{*}{ MB.C.13279.5 } & 14.89 & 10.47 & 8.32 & 0.79 & 4.55 & 0.70 & 1.26 & 0.05 & 2.07 & 0.45 \\
\hline & 10.34 & 8.23 & 5.77 & 0.85 & 3.05 & 0.80 & 1.43 & 0.08 & 2.01 & 0.47 \\
\hline & 7.29 & 6.37 & 3.73 & 1.09 & 1.90 & 0.87 & 1.71 & 0.15 & 1.83 & 0.49 \\
\hline & 5.39 & 4.75 & 2.47 & 1.28 & 1.26 & 0.88 & 1.92 & 0.24 & 1.70 & 0.49 \\
\hline & 4.13 & 3.54 & 1.64 & 1.36 & 0.84 & 0.86 & 2.16 & 0.33 & 1.57 & 0.49 \\
\hline & 3.29 & 2.67 & 1.13 & 1.28 & 0.61 & 0.81 & 2.37 & 0.39 & 1.50 & 0.46 \\
\hline & 2.68 & 2.19 & 0.89 & 1.13 & 0.52 & 0.82 & 2.47 & 0.42 & 1.54 & 0.41 \\
\hline & 2.16 & 1.67 & 0.67 & 0.94 & 0.41 & 0.78 & 2.50 & 0.44 & 1.53 & 0.39 \\
\hline & 1.75 & 1.33 & 0.55 & 0.74 & 0.38 & 0.76 & 2.44 & 0.42 & 1.64 & 0.30 \\
\hline & 1.37 & 1.03 & 0.47 & 0.52 & 0.32 & 0.75 & 2.21 & 0.38 & 1.70 & 0.32 \\
\hline & 1.05 & 0.88 & 0.38 & 0.29 & 0.24 & 0.84 & 2.29 & 0.28 & 1.67 & 0.38 \\
\hline & 0.81 & 0.64 & 0.37 & 0.06 & 0.23 & 0.78 & 1.70 & 0.07 & 1.93 & 0.39 \\
\hline \multicolumn{11}{|c|}{ Lusitanoceras zirari n. sp. } \\
\hline MB.C. 13250.1 & 54.70 & 34.40 & 27.60 & 7.50 & 12.70 & 0.63 & 1.25 & 0.14 & 1.70 & 0.54 \\
\hline MB.C.13296 & 31.20 & 21.40 & 14.90 & 5.00 & 5.90 & 0.69 & 1.44 & 0.16 & 1.52 & 0.61 \\
\hline MB.C.13288 & 23.50 & 17.30 & 10.10 & 3.50 & 4.40 & 0.74 & 1.71 & 0.15 & 1.52 & 0.56 \\
\hline MB.C.13261.1 & 12.60 & 10.80 & 6.90 & 1.60 & 2.90 & 0.86 & 1.58 & 0.12 & 1.67 & 0.58 \\
\hline \multirow[t]{8}{*}{ MB.C. 13247.2} & 27.78 & 19.97 & 13.92 & 3.10 & 5.60 & 0.72 & 1.43 & 0.11 & 1.57 & 0.60 \\
\hline & 22.18 & 16.22 & 10.76 & 3.10 & 4.21 & 0.73 & 1.51 & 0.14 & 1.52 & 0.61 \\
\hline & 17.97 & 14.20 & 8.32 & 2.73 & 3.06 & 0.79 & 1.71 & 0.15 & 1.45 & 0.63 \\
\hline & 14.91 & 11.66 & 6.92 & 2.60 & 3.07 & 0.78 & 1.68 & 0.17 & 1.59 & 0.56 \\
\hline & 11.85 & 10.57 & 5.39 & 1.81 & 2.44 & 0.89 & 1.96 & 0.15 & 1.59 & 0.55 \\
\hline & 9.40 & 8.54 & 4.64 & 1.59 & 1.87 & 0.91 & 1.84 & 0.17 & 1.56 & 0.60 \\
\hline & 7.54 & 7.12 & 3.17 & 1.54 & 1.43 & 0.94 & 2.25 & 0.20 & 1.52 & 0.55 \\
\hline & 6.11 & 5.63 & 2.84 & 1.39 & 1.30 & 0.92 & 1.99 & 0.23 & 1.61 & 0.54 \\
\hline \multirow[t]{4}{*}{ MB.C.13206.1 } & 22.11 & 16.56 & 9.97 & 3.72 & 4.21 & 0.75 & 1.66 & 0.17 & 1.53 & 0.58 \\
\hline & 17.90 & 14.15 & 8.43 & 2.60 & 3.65 & 0.79 & 1.68 & 0.15 & 1.58 & 0.57 \\
\hline & 14.25 & 12.51 & 6.87 & 1.98 & 2.58 & 0.88 & 1.82 & 0.14 & 1.49 & 0.62 \\
\hline & 11.67 & 9.95 & 5.40 & 1.71 & 2.16 & 0.85 & 1.84 & 0.15 & 1.51 & 0.60 \\
\hline
\end{tabular}




\section{B. (continued)}

\begin{tabular}{|c|c|c|c|c|c|c|c|c|c|c|}
\hline & $\mathrm{dm}$ & ww & wh & uw & ah & $w w / d m$ & ww/wh & $\mathrm{uw} / \mathrm{dm}$ & WER & IZW \\
\hline & 9.51 & 8.56 & 4.57 & 1.59 & 2.06 & 0.90 & 1.87 & 0.17 & 1.63 & 0.55 \\
\hline & 7.45 & 6.94 & 3.36 & 1.31 & 1.35 & 0.93 & 2.07 & 0.18 & 1.49 & 0.60 \\
\hline & 6.10 & 5.84 & 2.79 & 1.17 & 1.12 & 0.96 & 2.09 & 0.19 & 1.50 & 0.60 \\
\hline & 4.98 & 4.80 & 2.14 & 1.03 & 0.88 & 0.96 & 2.24 & 0.21 & 1.47 & 0.59 \\
\hline & 4.10 & 3.85 & 1.80 & 0.96 & 0.75 & 0.94 & 2.13 & 0.23 & 1.50 & 0.59 \\
\hline & 3.35 & 3.31 & 1.33 & 0.97 & 0.61 & 0.99 & 2.49 & 0.29 & 1.50 & 0.54 \\
\hline & 2.74 & 2.44 & 1.05 & 0.97 & 0.49 & 0.89 & 2.33 & 0.35 & 1.49 & 0.53 \\
\hline & 2.25 & 1.96 & 0.72 & 0.90 & 0.41 & 0.87 & 2.72 & 0.40 & 1.49 & 0.44 \\
\hline & 1.84 & 1.52 & 0.63 & 0.71 & 0.35 & 0.82 & 2.41 & 0.39 & 1.52 & 0.45 \\
\hline & 1.49 & 1.18 & 0.50 & 0.59 & 0.29 & 0.79 & 2.36 & 0.40 & 1.54 & 0.42 \\
\hline & 1.21 & 0.95 & 0.40 & - & 0.25 & 0.79 & 2.37 & - & 1.59 & 0.38 \\
\hline \multirow[t]{15}{*}{ MB.C. 13206.2} & 20.39 & 13.89 & 10.21 & 2.42 & 3.69 & 0.68 & 1.36 & 0.12 & 1.49 & 0.64 \\
\hline & 16.70 & 11.11 & 7.76 & 1.96 & 3.13 & 0.67 & 1.43 & 0.12 & 1.51 & 0.60 \\
\hline & 13.57 & 10.01 & 6.98 & 1.44 & 2.57 & 0.74 & 1.44 & 0.11 & 1.52 & 0.63 \\
\hline & 11.00 & 8.37 & 5.15 & 1.29 & 2.15 & 0.76 & 1.62 & 0.12 & 1.55 & 0.58 \\
\hline & 8.85 & 7.23 & 4.55 & 1.11 & 1.87 & 0.82 & 1.59 & 0.13 & 1.61 & 0.59 \\
\hline & 6.98 & 6.13 & 3.19 & 1.01 & 1.29 & 0.88 & 1.93 & 0.15 & 1.51 & 0.59 \\
\hline & 5.69 & 5.03 & 2.78 & 0.92 & 1.01 & 0.88 & 1.81 & 0.16 & 1.48 & 0.64 \\
\hline & 4.68 & 4.03 & 1.99 & 0.94 & 0.88 & 0.86 & 2.02 & 0.20 & 1.52 & 0.56 \\
\hline & 3.80 & 3.24 & 1.74 & 0.88 & 0.68 & 0.85 & 1.86 & 0.23 & 1.48 & 0.61 \\
\hline & 3.12 & 2.81 & 1.17 & 0.88 & 0.54 & 0.90 & 2.39 & 0.28 & 1.46 & 0.54 \\
\hline & 2.58 & 2.14 & 1.07 & 0.83 & 0.47 & 0.83 & 2.01 & 0.32 & 1.49 & 0.56 \\
\hline & 2.11 & 1.77 & 0.69 & 0.76 & 0.37 & 0.84 & 2.56 & 0.36 & 1.47 & 0.46 \\
\hline & 1.74 & 1.41 & 0.67 & 0.57 & 0.32 & 0.81 & 2.10 & 0.33 & 1.51 & 0.52 \\
\hline & 1.32 & 1.09 & 0.50 & 0.35 & 0.26 & 0.83 & 2.18 & 0.27 & 1.56 & 0.47 \\
\hline & 1.05 & 0.85 & 0.47 & 0.22 & 0.24 & 0.81 & 1.83 & 0.21 & 1.67 & 0.49 \\
\hline \multicolumn{11}{|c|}{ Sudeticeras murracaoense Korn, 1997} \\
\hline MB.C.13202.1 & 24.90 & 14.60 & 13.10 & 2.00 & 7.40 & 0.58 & 1.11 & 0.08 & 2.02 & 0.43 \\
\hline MB.C. 13271.1 & 15.10 & 10.70 & 8.60 & 1.00 & 4.40 & 0.71 & 1.24 & 0.07 & 2.01 & 0.48 \\
\hline MB.C.13271.2 & 13.30 & 9.20 & 7.70 & 0.90 & 4.20 & 0.70 & 1.20 & 0.07 & 2.12 & 0.46 \\
\hline MB.C.13202.2 & 12.30 & 9.30 & 6.20 & 1.30 & 3.20 & 0.76 & 1.50 & 0.11 & 1.81 & 0.49 \\
\hline MB.C.13203.1 & 10.30 & 8.10 & 5.80 & 0.50 & 2.80 & 0.79 & 1.39 & 0.05 & 1.87 & 0.53 \\
\hline \multirow[t]{6}{*}{ MB.C. 13205.1} & 16.27 & 11.19 & 9.14 & 0.80 & 4.73 & 0.69 & 1.22 & 0.05 & 1.99 & 0.48 \\
\hline & 11.53 & 8.60 & 6.33 & 0.82 & 3.40 & 0.75 & 1.36 & 0.07 & 2.01 & 0.46 \\
\hline & 8.14 & 6.98 & 4.39 & 0.92 & 2.18 & 0.86 & 1.59 & 0.11 & 1.87 & 0.50 \\
\hline & 5.96 & 5.14 & 2.83 & 0.92 & 1.28 & 0.86 & 1.82 & 0.15 & 1.62 & 0.55 \\
\hline & 4.67 & 4.17 & 2.21 & 0.85 & 1.03 & 0.89 & 1.88 & 0.18 & 1.64 & 0.54 \\
\hline & 3.65 & 3.49 & 1.61 & 0.82 & 0.69 & 0.96 & 2.16 & 0.23 & 1.52 & 0.57 \\
\hline \multirow[t]{11}{*}{ MB.C.13271.3 } & 14.16 & 9.40 & 7.58 & 0.99 & 3.98 & 0.66 & 1.24 & 0.07 & 1.93 & 0.47 \\
\hline & 10.18 & 7.63 & 5.59 & 0.77 & 2.86 & 0.75 & 1.36 & 0.08 & 1.93 & 0.49 \\
\hline & 7.32 & 5.61 & 3.82 & 0.93 & 2.08 & 0.77 & 1.47 & 0.13 & 1.95 & 0.46 \\
\hline & 5.25 & 4.52 & 2.58 & 0.81 & 1.34 & 0.86 & 1.75 & 0.15 & 1.81 & 0.48 \\
\hline & 3.90 & 3.41 & 1.86 & 0.77 & 0.90 & 0.87 & 1.83 & 0.20 & 1.69 & 0.52 \\
\hline & 3.01 & 2.77 & 1.27 & 0.77 & 0.71 & 0.92 & 2.18 & 0.26 & 1.72 & 0.44 \\
\hline & 2.29 & 2.05 & 0.97 & 0.67 & 0.53 & 0.89 & 2.12 & 0.29 & 1.69 & 0.45 \\
\hline & 1.76 & 1.43 & 0.66 & 0.56 & 0.41 & 0.81 & 2.18 & 0.32 & 1.70 & 0.37 \\
\hline & 1.35 & 1.10 & 0.55 & 0.33 & 0.36 & 0.82 & 2.01 & 0.24 & 1.85 & 0.35 \\
\hline & 0.99 & 0.77 & 0.47 & 0.16 & 0.27 & 0.77 & 1.61 & 0.16 & 1.90 & 0.43 \\
\hline & 0.72 & 0.72 & 0.36 & 0.03 & 0.23 & 1.00 & 2.01 & 0.04 & 2.15 & 0.36 \\
\hline \multirow[t]{3}{*}{ MB.C.13271.4 } & 21.36 & 13.37 & 11.82 & 0.99 & 6.39 & 0.63 & 1.13 & 0.05 & 2.04 & 0.46 \\
\hline & 14.97 & 9.88 & 8.55 & 0.55 & 4.26 & 0.66 & 1.16 & 0.04 & 1.95 & 0.50 \\
\hline & 10.71 & 7.92 & 5.87 & 0.47 & 2.82 & 0.74 & 1.35 & 0.04 & 1.84 & 0.52 \\
\hline \multicolumn{11}{|c|}{ Sudeticeras ibnbajjahi n. sp. } \\
\hline MB.C.13241.1 & 21.40 & 14.40 & 11.10 & 1.50 & 6.30 & 0.67 & 1.30 & 0.07 & 2.02 & 0.43 \\
\hline MB.C.13225.1 & 15.60 & 11.70 & 8.20 & 1.70 & 4.40 & 0.75 & 1.43 & 0.11 & 1.93 & 0.46 \\
\hline
\end{tabular}


B. (continued)

\begin{tabular}{|c|c|c|c|c|c|c|c|c|c|c|}
\hline & $\mathrm{dm}$ & ww & wh & uw & ah & $w w / d m$ & ww/wh & $\mathrm{uw} / \mathrm{dm}$ & WER & IZW \\
\hline MB.C. 13225.5 & 11.60 & 9.60 & 5.50 & 1.30 & 3.10 & 0.83 & 1.76 & 0.11 & 1.84 & 0.44 \\
\hline MB.C. 13225.2 & 10.70 & 8.60 & 5.50 & 1.10 & 2.90 & 0.81 & 1.57 & 0.11 & 1.87 & 0.48 \\
\hline \multirow[t]{4}{*}{ MB.C. 13225.3} & 16.55 & 11.60 & 9.14 & 1.00 & 4.54 & 0.70 & 1.27 & 0.06 & 1.90 & 0.50 \\
\hline & 12.01 & 9.78 & 6.41 & 0.83 & 3.24 & 0.81 & 1.52 & 0.07 & 1.87 & 0.50 \\
\hline & 8.77 & 7.39 & 4.77 & 0.82 & 2.51 & 0.84 & 1.55 & 0.09 & 1.96 & 0.47 \\
\hline & 6.27 & 5.88 & 3.18 & 0.91 & 1.64 & 0.94 & 1.85 & 0.15 & 1.83 & 0.49 \\
\hline \multirow[t]{10}{*}{ MB.C.13225.4 } & 14.78 & 9.91 & 8.24 & 0.68 & 4.34 & 0.67 & 1.20 & 0.05 & 2.00 & 0.47 \\
\hline & 10.44 & 7.97 & 5.85 & 0.54 & 3.03 & 0.76 & 1.36 & 0.05 & 1.98 & 0.48 \\
\hline & 7.42 & 6.37 & 4.05 & 0.61 & 2.11 & 0.86 & 1.57 & 0.08 & 1.95 & 0.48 \\
\hline & 5.31 & 4.81 & 2.76 & 0.59 & 1.44 & 0.91 & 1.75 & 0.11 & 1.88 & 0.48 \\
\hline & 3.87 & 3.87 & 1.96 & 0.67 & 1.03 & 1.00 & 1.98 & 0.17 & 1.86 & 0.47 \\
\hline & 2.84 & 2.75 & 1.25 & 0.68 & 0.69 & 0.97 & 2.20 & 0.24 & 1.75 & 0.45 \\
\hline & 2.15 & 2.03 & 0.91 & 0.64 & 0.51 & 0.95 & 2.23 & 0.30 & 1.72 & 0.44 \\
\hline & 1.64 & 1.41 & 0.60 & 0.55 & 0.37 & 0.86 & 2.35 & 0.34 & 1.67 & 0.38 \\
\hline & 1.27 & 1.08 & 0.49 & 0.36 & 0.30 & 0.85 & 2.20 & 0.29 & 1.72 & 0.38 \\
\hline & 0.97 & 0.79 & 0.42 & 0.23 & 0.27 & 0.81 & 1.89 & 0.23 & 1.93 & 0.35 \\
\hline \multicolumn{11}{|c|}{ Sudeticeras splendens (Bisat, 1928) } \\
\hline MB.C. 13264.1 & 54.70 & 27.70 & 26.20 & 8.30 & 15.40 & 0.51 & 1.02 & 0.15 & 1.94 & 0.43 \\
\hline MB.C. 13264.4 & 50.40 & 26.60 & 25.70 & 6.70 & 14.30 & 0.53 & 1.03 & 0.13 & 1.95 & 0.44 \\
\hline MB.C.13264.2 & 50.10 & 28.20 & 25.30 & 6.60 & 13.50 & 0.56 & 1.11 & 0.13 & 1.88 & 0.47 \\
\hline MB.C. 13264.5 & 45.60 & 25.80 & 22.60 & 7.70 & 12.30 & 0.57 & 1.14 & 0.17 & 1.87 & 0.46 \\
\hline MB.C.13264.6 & 30.30 & 18.90 & 13.80 & 5.90 & 8.00 & 0.62 & 1.37 & 0.20 & 1.85 & 0.42 \\
\hline \multirow[t]{5}{*}{ MB.C.13248.1 } & 47.21 & 24.27 & 23.66 & 6.44 & 12.57 & 0.51 & 1.03 & 0.14 & 1.86 & 0.47 \\
\hline & 34.64 & 19.80 & 17.11 & 5.08 & 9.28 & 0.57 & 1.16 & 0.15 & 1.87 & 0.46 \\
\hline & 25.36 & 15.72 & 12.45 & 3.52 & 6.60 & 0.62 & 1.26 & 0.14 & 1.83 & 0.47 \\
\hline & 18.76 & 12.44 & 9.39 & 2.50 & 4.54 & 0.66 & 1.33 & 0.13 & 1.74 & 0.52 \\
\hline & 14.22 & 10.14 & 6.88 & - & 3.43 & 0.71 & 1.48 & - & 1.74 & 0.50 \\
\hline \multicolumn{11}{|c|}{ Sudeticeras horoni n. sp. } \\
\hline MB.C. 13260.1 & 68.50 & 30.40 & 33.20 & 9.40 & 19.50 & 0.44 & 0.91 & 0.14 & 1.96 & 0.41 \\
\hline MB.C. 13260.3 & 47.70 & 24.70 & 23.20 & 5.40 & 13.20 & 0.52 & 1.06 & 0.11 & 1.91 & 0.43 \\
\hline MB.C.13212.2 & 47.10 & 23.20 & 24.80 & 4.30 & 13.80 & 0.49 & 0.93 & 0.09 & 1.99 & 0.45 \\
\hline MB.C.13212.1 & 44.60 & 24.30 & 24.60 & 3.80 & 12.70 & 0.54 & 0.99 & 0.09 & 1.95 & 0.48 \\
\hline MB.C.13289.1 & 41.10 & 20.90 & 23.20 & 2.30 & 11.90 & 0.51 & 0.90 & 0.06 & 1.98 & 0.49 \\
\hline MB.C. 13212.4 & 27.00 & 16.00 & 13.80 & 3.00 & 7.30 & 0.59 & 1.16 & 0.11 & 1.88 & 0.47 \\
\hline MB.C.13212.3 & 24.10 & 15.60 & 13.00 & 2.20 & 6.70 & 0.65 & 1.20 & 0.09 & 1.91 & 0.48 \\
\hline \multirow[t]{12}{*}{ MB.C.13246 } & 50.86 & 24.14 & 26.14 & 4.81 & 14.31 & 0.47 & 0.92 & 0.09 & 1.94 & 0.45 \\
\hline & 36.55 & 20.27 & 19.91 & 3.32 & 11.14 & 0.55 & 1.02 & 0.09 & 2.07 & 0.44 \\
\hline & 25.42 & 16.99 & 13.32 & 2.68 & 7.08 & 0.67 & 1.28 & 0.11 & 1.92 & 0.47 \\
\hline & 18.33 & 13.19 & 9.42 & 1.74 & 4.65 & 0.72 & 1.40 & 0.10 & 1.80 & 0.51 \\
\hline & 13.68 & 10.27 & 7.17 & 1.48 & 3.56 & 0.75 & 1.43 & 0.11 & 1.83 & 0.50 \\
\hline & 10.13 & 8.48 & 5.03 & 1.45 & 2.45 & 0.84 & 1.69 & 0.14 & 1.74 & 0.51 \\
\hline & 7.68 & 6.53 & 3.65 & 1.22 & 1.66 & 0.85 & 1.79 & 0.16 & 1.63 & 0.55 \\
\hline & 6.03 & 5.37 & 2.82 & 1.19 & 1.38 & 0.89 & 1.91 & 0.20 & 1.68 & 0.51 \\
\hline & 4.65 & 4.49 & 2.01 & 1.12 & 0.96 & 0.96 & 2.23 & 0.24 & 1.59 & 0.52 \\
\hline & 3.69 & 3.40 & 1.52 & 1.10 & 0.77 & 0.92 & 2.24 & 0.30 & 1.59 & 0.49 \\
\hline & 2.92 & 2.57 & 1.07 & 0.96 & 0.58 & 0.88 & 2.40 & 0.33 & 1.56 & 0.46 \\
\hline & 2.34 & 1.87 & 0.89 & 0.80 & 0.49 & 0.80 & 2.10 & 0.34 & 1.60 & 0.45 \\
\hline \multirow[t]{7}{*}{ MB.C. 13266.1} & 50.65 & 24.70 & 26.47 & 4.62 & 14.12 & 0.49 & 0.93 & 0.09 & 1.92 & 0.47 \\
\hline & 36.53 & 20.45 & 19.56 & 3.17 & 10.75 & 0.56 & 1.05 & 0.09 & 2.01 & 0.45 \\
\hline & 25.78 & 16.65 & 13.79 & 2.18 & 7.36 & 0.65 & 1.21 & 0.08 & 1.96 & 0.47 \\
\hline & 18.42 & 12.89 & 9.81 & 1.58 & 4.87 & 0.70 & 1.31 & 0.09 & 1.85 & 0.50 \\
\hline & 13.55 & 10.08 & 7.03 & 1.27 & 3.47 & 0.74 & 1.43 & 0.09 & 1.81 & 0.51 \\
\hline & 10.08 & 7.95 & 5.25 & 1.32 & 2.36 & 0.79 & 1.51 & 0.13 & 1.71 & 0.55 \\
\hline & 7.72 & 6.22 & 3.52 & 1.24 & 1.53 & 0.81 & 1.77 & 0.16 & 1.56 & 0.56 \\
\hline
\end{tabular}


B. (continued)

\begin{tabular}{ccccccccccc}
\hline & $\mathrm{dm}$ & ww & wh & uw & ah & ww/dm & ww/wh & uw/dm & WER & IZW \\
\hline $\begin{array}{c}\text { Neoglyphioceras spirale (Phillips, 1841) } \\
\text { MB.C.13242.1 }\end{array}$ & 17.90 & 9.00 & 7.90 & - & 4.00 & 0.50 & 1.15 & - & 1.65 & 0.50 \\
MB.C.13226.1 & 12.60 & 7.30 & 5.30 & 3.40 & - & 0.58 & 1.38 & 0.27 & - & - \\
MB.C.13226.3 & 17.13 & 8.70 & 8.40 & 1.98 & 3.50 & 0.51 & 1.04 & 0.12 & 1.58 & 0.58 \\
& 13.63 & 7.44 & 6.76 & 1.98 & 2.95 & 0.55 & 1.10 & 0.15 & 1.63 & 0.56 \\
& 10.69 & 6.58 & 4.90 & 2.00 & 2.20 & 0.62 & 1.34 & 0.19 & 1.58 & 0.55 \\
MB.C.13226.2 & 16.64 & 9.31 & 7.52 & 3.19 & 2.94 & 0.56 & 1.24 & 0.19 & 1.47 & 0.61 \\
& 13.71 & 8.30 & 5.94 & 2.83 & 2.49 & 0.61 & 1.40 & 0.21 & 1.49 & 0.58 \\
& 11.22 & 7.02 & 4.95 & 2.63 & 2.21 & 0.63 & 1.42 & 0.23 & 1.55 & 0.55 \\
& 9.01 & 6.18 & 3.65 & 2.34 & 1.47 & 0.69 & 1.69 & 0.26 & 1.43 & 0.60 \\
& 7.54 & 5.28 & 3.03 & 2.18 & 1.47 & 0.70 & 1.74 & 0.29 & 1.54 & 0.52 \\
& 6.08 & 4.54 & 2.33 & 2.14 & 1.26 & 0.75 & 1.94 & 0.35 & 1.59 & 0.46 \\
& 4.82 & 3.64 & 1.60 & 1.97 & 0.84 & 0.75 & 2.28 & 0.41 & 1.47 & 0.48 \\
& 3.98 & 3.01 & 1.26 & - & 0.73 & 0.76 & 2.40 & - & 1.50 & 0.42
\end{tabular}

Lusitanites circularis Korn, 1988

$\begin{array}{lllllllllll}\text { MB.C.13249.1 } & 17.90 & 8.70 & - & - & - & 0.48 & - & - & - & - \\ \text { MB.C.13208.1 } & 17.20 & 7.40 & 8.00 & 2.50 & - & 0.43 & 0.92 & 0.14 & - \\ \text { MB.C.13249.2 } & 17.10 & 8.20 & 8.00 & 2.10 & 3.60 & 0.48 & 1.03 & 0.13 & 1.60 & 0.55 \\ \text { MB.C.13262.2 } & 17.10 & 7.90 & 7.60 & 2.10 & - & 0.46 & 1.03 & 0.12 & - & -\end{array}$

Praedaraelites culmiensis (Kobold, 1933)

\begin{tabular}{|cccccccccccc}
\hline MB.C.13295 & 22.00 & 6.50 & 10.20 & 5.70 & 8.50 & 0.29 & 0.63 & 0.26 & 2.67 & 0.16 \\
\hline MB.C.13231.1 & 20.40 & 6.40 & 9.20 & 5.60 & 8.10 & 0.31 & 0.69 & 0.27 & 2.75 & 0.12 \\
\hline MB.C.13243.1 & 17.60 & 5.80 & 7.50 & 5.30 & 6.60 & 0.33 & 0.77 & 0.30 & 2.58 & 0.12 \\
\hline MB.C.13227.1 & 15.70 & 5.10 & 6.80 & 4.60 & 6.10 & 0.33 & 0.75 & 0.29 & 2.64 & 0.11 \\
\hline MB.C.13227.2 & 10.70 & 3.80 & 4.90 & 3.30 & 4.20 & 0.35 & 0.76 & 0.31 & 2.66 & 0.16 \\
\hline MB.C.13227.3 & 21.59 & 6.93 & 9.83 & 5.63 & 8.45 & 0.32 & 0.70 & 0.26 & 2.70 & 0.14 \\
& 13.14 & 4.67 & 6.13 & 3.87 & 5.27 & 0.36 & 0.76 & 0.29 & 2.79 & 0.14 \\
& 7.87 & 3.14 & 3.14 & 2.82 & 2.85 & 0.40 & 1.00 & 0.36 & 2.46 & 0.09 \\
\hline & 5.02 & 1.82 & 1.91 & 1.88 & 1.76 & 0.36 & 0.95 & 0.38 & 2.36 & 0.08 \\
& 3.26 & 1.23 & 1.22 & 1.24 & 1.08 & 0.38 & 1.01 & 0.38 & 2.24 & 0.11 \\
& 2.18 & 0.77 & 0.80 & 0.84 & 0.73 & 0.35 & 0.97 & 0.38 & 2.25 & 0.09 \\
\hline Pronorites owodenkoi n. sp. & 1.46 & 0.57 & 0.54 & 0.47 & 0.49 & 0.39 & 1.06 & 0.32 & 2.25 & 0.11 \\
\hline MB.C.13287.1 & 0.97 & 0.41 & 0.44 & 0.22 & 0.41 & 0.42 & 0.93 & 0.22 & 2.95 & 0.08 \\
\hline MB.C.13287.2 & & & & & & & & & \\
\hline MB.C.13244.1 & 40.30 & 14.10 & 20.30 & 7.40 & 15.10 & 0.35 & 0.70 & 0.18 & 2.56 & 0.25 \\
\hline & 36.80 & 11.70 & 17.60 & - & 13.30 & 0.32 & 0.66 & - & 2.45 & 0.25 \\
\hline & 25.42 & 7.29 & 11.27 & 7.86 & 8.40 & 0.29 & 0.65 & 0.31 & 2.23 & 0.25 \\
\hline & 17.02 & 4.77 & 6.29 & 6.90 & 5.12 & 0.28 & 0.76 & 0.41 & 2.04 & 0.19 \\
\hline & 11.90 & 3.40 & 3.84 & 5.77 & 3.23 & 0.29 & 0.89 & 0.48 & 1.88 & 0.16 \\
\hline & 8.67 & 2.41 & 2.30 & - & 2.18 & 0.28 & 1.05 & - & 1.79 & 0.05 \\
\hline
\end{tabular}

